\title{
8. SITE $701^{1}$
}

\author{
Shipboard Scientific Party²
}

HOLE 701A

Date occupied: 4 April 1987

Date departed: 6 April 1987

Time on hole: 1 day, $18 \mathrm{hr}$

Position: $51^{\circ} 59.076^{\prime} \mathrm{S}, 23^{\circ} 12.736^{\prime} \mathrm{W}$

Bottom felt (rig floor; m; drill-pipe measurement): 4647.2

Distance between rig floor and sea level $(\mathrm{m}): 10.50$

Water depth (drill floor measurement from sea level; corrected $\mathrm{m}$ ): 4636.7

Total depth (rig floor; corrected m): 4722.0

Penetration (m): 74.8

Number of cores: 8

Total length of cored section $(\mathrm{m}): \mathbf{7 4 . 8}$

Total core recovered $(\mathrm{m}): 69.66$

Core recovery (\%): 93

Oldest sediment cored:

Depth sub-bottom (m): 74.8

Nature: ash- and mud-bearing diatom ooze

Age: late Pliocene

Measured velocity $(\mathrm{km} / \mathrm{s}): 1.52$

\section{HOLE 701B}

Date occupied: 6 April 1987

Date departed: 8 April 1987

Time on hole: $19 \mathrm{hr}$

Position: $51^{\circ} 59.0775^{\prime} \mathrm{S}, 23^{\circ} 12.735^{\prime} \mathrm{W}$

Bottom felt (rig floor; $\mathrm{m}$; drill-pipe measurement): 4647.2

Distance between rig floor and sea level $(\mathrm{m}): 10.50$

Water depth (drill floor measurement from sea level; corrected m): 4636.7

Total depth (rig floor; corrected m): 4850.2

Penetration (m): 203.0

Number of cores: 14

Total length of cored section (m): 133.0

Total core recovered $(\mathrm{m}): 96.36$

Core recovery (\%): 72

Oldest sediment cored:

Depth sub-bottom (m): 203.0

Nature: clay-bearing diatom ooze

Age: late Miocene

Measured velocity $(\mathrm{km} / \mathrm{s}): 1.55$ at $188 \mathrm{mbsf}$

\footnotetext{
${ }^{1}$ Ciesielski, P. F., Kristoffersen, Y., et al., 1988. Proc. ODP, Init. Repts., 114 College Station, TX (Ocean Drilling Program).

${ }^{2}$ Shipboard Scientific Party is as given in the list of Participants preceding the contents with the addition of M. Perfit, Department of Geology, University of Florida, Gainesville, FL 32611.
}

HOLE 701C

Date occupied: 8 April 1987

Date departed: 11 April 1987

Time on hole: 4 days, $6 \mathrm{hr}$

Position: $51^{\circ} 59.085^{\prime} \mathrm{S}, 23^{\circ} 12.700^{\prime} \mathrm{W}$

Bottom felt (rig floor; m; drill-pipe measurement): 4647.2

Distance between rig floor and sea level $(\mathrm{m}): 10.50$

Water depth (drill floor measurement from sea level; corrected m): 4636.7

Total depth (rig floor; corrected m): 5128.6

Penetration (m): 481.4

Number of cores: 51

Total length of cored section (m): 481.4

Total core recovered $(\mathrm{m}): 331.14$

Core recovery $(\%): 68$

Oldest sediment cored:

Depth sub-bottom (m): 471.8

Nature: indurated nannofossil chalk

Age: early middle Eocene

Measured velocity $(\mathrm{km} / \mathrm{s}): 1.6$ at $441.4 \mathrm{mbsf}$

Basement:

Depth sub-bottom (m): 471.8-481.3 from Core 114-701C-52W, which recovered basalt from the lower interval of Core 114-701C-51X where a bit was destroyed

Nature: variably altered amygdaloidal olivine basalt

Measured velocity range $(\mathrm{km} / \mathrm{s}): 5.0$

Principal results: Site 701 is on the western flank of the Mid-Atlantic Ridge $\left(51^{\circ} 59.07^{\prime} \mathrm{S}, 23^{\circ} 12.73^{\prime} \mathrm{W}\right.$, in a water depth of $\left.4636.7 \mathrm{~m}\right)$, about $160 \mathrm{~km}$ east of the Islas Orcadas Rise on oceanic crust of middle Eocene age (Chron C22). The major objective of this site was to obtain a continuous sediment record of the development of an oceanic gateway for deep circulation between the South Atlantic and the Weddell Basin. In conjunction with the shallower Sites 699 and 700 , Site 701, which is situated within the gateway, provides the basis for interpretation of the history of deep-water circulation through the gateway as a result of its increasing width and the subsidence of the surrounding seafloor. In addition, Site 701 and other Leg 114 sites provide the opportunity to evaluate the development of vertical temperature gradients during the Paleogene.

Site 701 consists of three holes: Hole 701A, with 8 cores obtained with the advanced hydraulic piston corer (APC) to a depth of 74.8 mbsf for a recovery of $69.66 \mathrm{~m}(93.1 \%)$; Hole 701B, with 10 cores obtained with the APC and 4 cores with the extended core barrel (XCB) system between 70 to 203 mbsf for a recovery of $96.4 \mathrm{~m}$ $(72.5 \%)$; and Hole 701C, with 24 cores obtained with the APC and 27 with the XCB system, penetrated to $481.3 \mathrm{mbsf}$ for a recovery of $331.1 \mathrm{~m}(68.8 \%)$. A flared XCB bit prevented retrieval of the core barrel after penetration of a hard layer. Subsequent preparations to log through the pipe were abandoned after the drill string temporarily became stuck above the jars.

The stratigraphic section at Hole $701 \mathrm{C}$ consists of $400 \mathrm{~m}$ of mostly biosiliceous and diatom ooze, siliceous clay/mud, and claybearing diatom ooze overlying a 72 -m-thick sequence that shows increasing carbonate content with depth. The dominant lithologies and ages of the stratigraphic sequence are as follows: 
0-145.5 mbsf: diatom ooze, mud-bearing diatom ooze, and muddy diatom ooze with intervals of dispersed ash and numerous discrete ash layers. Ice-rafted detritus is present throughout this unit of late Miocene to Quaternary age.

145.5-176.8 mbsf: a late Miocene age monospecific diatom ooze with an interbedded sand and gravel unit containing quartz, biotite, metapelites, iron-coated schists, pumice, and mud clasts.

176.8-243.8 mbsf: clay- and mud-bearing diatom ooze of middle to late Miocene age. Volcanic ash is present as discrete and disseminated horizons throughout this unit.

243.8-395.15 mbsf: diatom-bearing mud/clay and siliceous mud/ clay with altered ash horizons throughout. This unit is of early to middle Miocene age.

395.15-452.8 mbsf: alternating intervals of nannofossil ooze, siliceous ooze, and clay of middle/late Eocene to late Oligocene age.

452.8-481.3 mbsf: indurated nannofossil chalk of early to late middle Eocene age.

481.3-481.47 mbsf: a single piece of variably altered amygdaloidal olivine basalt with quenched textures (MORB).

The sedimentary record of Site 701, the only Leg 114 site under the influence of Antarctic Bottom Water (AABW), differs significantly from the previous sites, which are under the influence of Circumpolar Deep Water (CPDW). The Neogene sequence is thicker, and the Paleogene is more attenuated than at the previous sites. The biogenic sedimentation was dominantly calcareous during the middle Eocene and biosiliceous in the late Eocene-Quaternary. After a brief interval of sedimentation above the carbonate compensation depth (CCD), a lengthy period of deposition occurred first below the CCD and later south of the carbonate productivity zone. Siliceous microfossils provide a detailed biostratigraphy of the Neogene that is complemented by a paleomagnetic record of the Brunhes Chron to chron C3AR. Biostratigraphic resolution of the middle Eocene to early Oligocene is provided by calcareous and siliceous microfossil groups.

Two hiatuses occur within the Paleocene section of Hole 701C. One hiatus includes the upper middle Eocene and possibly the lowermost upper Eocene for an estimated maximum duration of 7.0 m.y. $(\sim 46.0-39.0 \mathrm{Ma})$ to a minimum of $2.4 \mathrm{~m} . \mathrm{y} .(\sim 42.3-39.9 \mathrm{Ma})$. The second Paleogene hiatus encompasses the upper lower Oligocene and upper Oligocene, with a maximum duration of 11.6 m.y. (35.0$23.4 \mathrm{Ma}$ ) to a minimum of $8.6 \mathrm{~m}$.y. (32.0-23.4 Ma). Given the uncertainty of the age range of these hiatuses, sedimentation rates for the intervening upper Eocene-lower Oligocene are within a range of 8 to $15 \mathrm{~m} / \mathrm{m} . \mathrm{y}$.

A minimum of three hiatuses were detected within the Neogene sequence of Holes 701A, 701B, and 701C. The oldest of these includes the upper lower Miocene and most or all of the upper Miocene, with a maximum duration of 7.6 m.y. $(\sim 19.0-11.4 \mathrm{Ma})$ and a minimum of 4.6 m.y. ( 19.0-14.4 Ma). A second Neogene hiatus occurs within the upper Miocene, representing a period of approximately 2.3 m.y. ( 8.7-6.4 Ma). Another brief hiatus occurs within the upper Pliocene between $\sim 3.0$ to $2.5 \mathrm{Ma}$.

Neogene sedimentation rates were highly variable. Although biostratigraphic control is poor for the lower Miocene (Subunit IIB), there is little doubt that the sedimentation rate was very high, as much as $68 \mathrm{~m} / \mathrm{m}$.y. Following the resumption of deposition after formation of the lower Neogene hiatus, sedimentation rates were much lower $(9-14 \mathrm{~m} / \mathrm{m} . \mathrm{y}$.) during the middle to early late Miocene. The mean sedimentation rate for the late Miocene through early Pliocene was $\sim 19 \mathrm{~m} / \mathrm{m}$.y. After the formation of the Gauss Chron hiatus $(\sim 3.0-2.5 \mathrm{Ma})$, sedimentation rates averaged $\sim 28 \mathrm{~m} / \mathrm{m}$.y. for the remainder of the late Pliocene-Quaternary.

The sedimentary record of Site 701 documents the opening of the deep-water gap between the Islas Orcadas and Meteor rises and the accompanying changes in benthic circulation. Nannofossil ooze began accumulating over basement during the initial stages (early middle Eocene) of the opening of the passageway between the rises. At this time, current intensity was low as a consequence of the still weak latitudinal temperature gradients, which allowed the deposition of warm-water assemblages of planktonic foraminifers and calcareous nannofossils above the CCD. A major increase in benthic current velocity took place between the middle middle Eocene and late Eocene, resulting in a 2.4-7.0-m.y. hiatus. Deposition was renewed by 40 to $39 \mathrm{Ma}$; however, sedimentation was slow and probably discon- tinuous, which resulted in an accumulation of only $\sim 60 \mathrm{~m}$ of upper Eocene to lower Oligocene sediment. Late Eocene subsidence of the site below the CCD (to $4000 \mathrm{~m}$ by the early Oligocene) led to the last consistent occurrence of foraminifers and calcareous nannofossils at this time. A thick sequence of biosiliceous muds and clays overlies the attenuated upper Eocene-lower Oligocene sequence. A significant increase in sedimentation rates during the late Oligocene at Sites 699 and 701 is attributed partially to a higher rate of terrigenous supply by CPDW and AABW. The formation of a deep-water gap in the Drake Passage led to the development of a true Antarctic Circumpolar Current (ACC) by the early Miocene. Shortly after the earliest Miocene northward advance of the polar front (Site 699), a regional hiatus was formed between lower Miocene to upper middle or upper Miocene sediments. This hiatus is found at Sites 699 and 701 and other regional sites, which suggests an age-equivalent increase in the intensity of CPDW and AABW.

The almost uninterrupted late Miocene to Quaternary sedimentation at this site contrasts greatly with our previous sites, which are under the influence of CPDW, indicating that CPDW was a more active agent of erosion or nondeposition than AABW. Discrete and dispersed volcanic ash occur throughout the upper Miocene-Quaternary in such quantity to indicate that this atmospherically transported ash may have had a significant impact on antarctic climate.

\section{BACKGROUND AND OBJECTIVES}

Site 701 (Fig. 1) is about $160 \mathrm{~km}$ east of Islas Orcadas Rise and $350 \mathrm{~km}$ south of the Falkland Fracture Zone at $51^{\circ} 59.08^{\prime} \mathrm{S}$, $23^{\circ} 12.73^{\prime} \mathrm{W}$, in a water depth of $4636.7 \mathrm{~m}$. The site is on middle Eocene oceanic crust generated at the Mid-Atlantic Ridge. The major objective of Site 701 was to obtain a continuously cored sediment record of the development of a deep-water oceanic gateway between the South Atlantic and the Weddell Basin (Fig. 2). In conjunction with Sites 699 and 700, the sediments at Site 701 provide the basis for interpreting the history of deep-water circulation through the gateway as a result of its increasing width and the subsidence of the surrounding relief. Site 701 is crucial in interpreting the paleoceanographic history of this teleconnective passageway and its influence on the paleoenvironment to the north and south because it was the only site drilled within the gateway during Leg 114 .

The acoustic signature of the sediments above oceanic crust east of the Islas Orcadas Rise is characterized by a lower transparent unit with deep and irregular incisions cut into its upper surface. The overlying, well-stratified unit comprises about two thirds of the total section but has a very irregular lateral distribution (Fig. 3). The seismic data evidence a dramatic change in the depositional regime in which deposition of the upper stratified unit was cut by a major erosional event. The large and irregular, but smooth, lateral changes in the thickness of the upper stratified unit are characteristic of sediments laid down under the influence of strong bottom currents. The crests of individual sediment lenses within the irregular basement topography have remained stationary or migrated only slightly with time (Fig. 3). Thus, the temporal and spatial pattern of bottomwater flow has therefore remained rather stable since the onset of any significant bottom circulation.

Site 701 occupies a similar position with respect to the presentday interaction of antarctic and subantarctic surface-water masses at the Antarctic Convergence Zone (ACZ), as described previously ("Background and Objectives" section, "Site 698" chapter, this volume). Present-day seasonal variations of the ACZ occur over the site, allowing for limited biogenic carbonate production in the surface waters. Little Neogene carbonate sediment was expected at this deep site $(4636.7 \mathrm{mbsl})$ because it had remained below the $C C D$ and south of or very close to the $A C Z$ during most of this time (Ciesielski and Weaver, 1983; Ledbetter and Ciesielski, 1982).

Site 701 is presently within one of the two principal avenues for the migration of AABW from the Weddell Sea and Scotia 


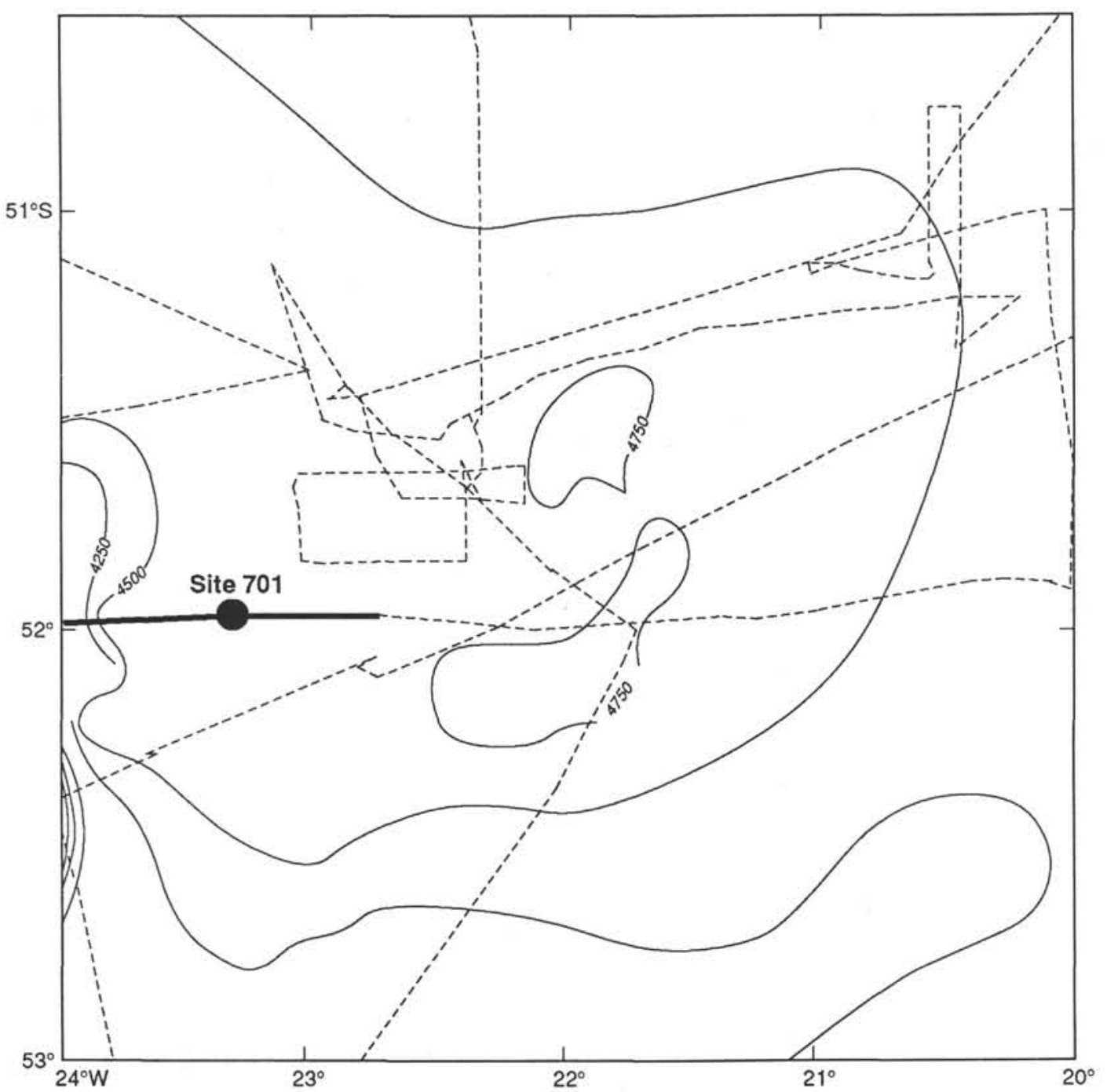

Figure 1. Location of Site 701. The bold line indicates the location of the seismic profile in Figure 3. Bathymetry in meters.

Sea into the Argentine Basin. One of the principal paths of AABW northward to the Argentine Basin is through the East Georgia Basin, where it flows as a deep western boundary undercurrent below the $4000-\mathrm{m}$ isobath of the eastern flank of the Northeast Georgia Rise (Ledbetter, 1986). A second minor branch of AABW enters the South Sandwich Basin through the Bullard Fracture Zone and continues northward along the eastern flank of the Islas Orcadas Rise to the eastern extremity of the Falkland Fracture Zone (Ledbetter and Ciesielski, 1986; Ledbetter, 1986). Site 701 is in close proximity to this eastern, weaker branch of AABW, which flows as a deep western boundary undercurrent along the eastern flank of the Islas Orcadas Rise.

Geophysical data indicate that prior to the formation of the gateway between the Islas Orcadas Rise and the Meteor Rise, a major impediment existed to bottom, deep, and intermediate water-mass exchange between the antarctic and South Atlantic basins. During the Late Cretaceous-Paleocene to early Eocene, a system of linked bathymetric highs extending from South America to Africa interfered with oceanic exchange. Barriers to circulation at this time were, from west to east, the Falkland Plateau, Falkland Fracture Zone, Northeast Georgia Rise, Islas Orcadas Rise, Agulhas Fracture Zone, and Agulhas Plateau. The Falkland-Agulhas ridge system remained relatively shallow through much of the Paleogene, restricting meridional deep-wa- ter exchange in a manner analogous to the Iceland-GreenlandFaeroe Ridge in the North Atlantic. During the Eocene a breach began forming in the Falkland-Agulhas Ridge system as the Islas Orcadas Rise and Meteor Rise began rifting apart, resulting in the formation of a 4000 -m-deep gap by the early Oligocene. The major purpose of Site 701 was to provide a geologic record of this important deep-water passage.

A number of late Paleogene to Neogene tectonic events probably influenced the nature of the sedimentary record at Site 701 as a result of their influence on the intensity of the flow of AABW or its precursor "pre-AABW." These events were reviewed in previous site chapters (see "Background and Objectives" section, "Site 699" chapter, this volume) and include the opening of the Drake Passage (23.5 $\pm 2.5 \mathrm{Ma}$; Barker and Burrell, 1977, 1982), north-south extension of the Central Scotia Sea (21 to $6 \mathrm{Ma}$; Hill and Barker, 1980), dispersal of the North Scotia Ridge (late Oligocene to late Miocene; Barker et al., 1984), and the development of back-arc extension in the East Scotia Sea and eastward migration of the Scotia arc (8 Ma to Present; Barker and Hill, 1981). These events have both impeded and enhanced the circulation of AABW and may be related to the temporal distribution of Neogene hiatuses, changes in sedimentation rates, and fluctuations in biogenic and terrigenous sedimentation. 

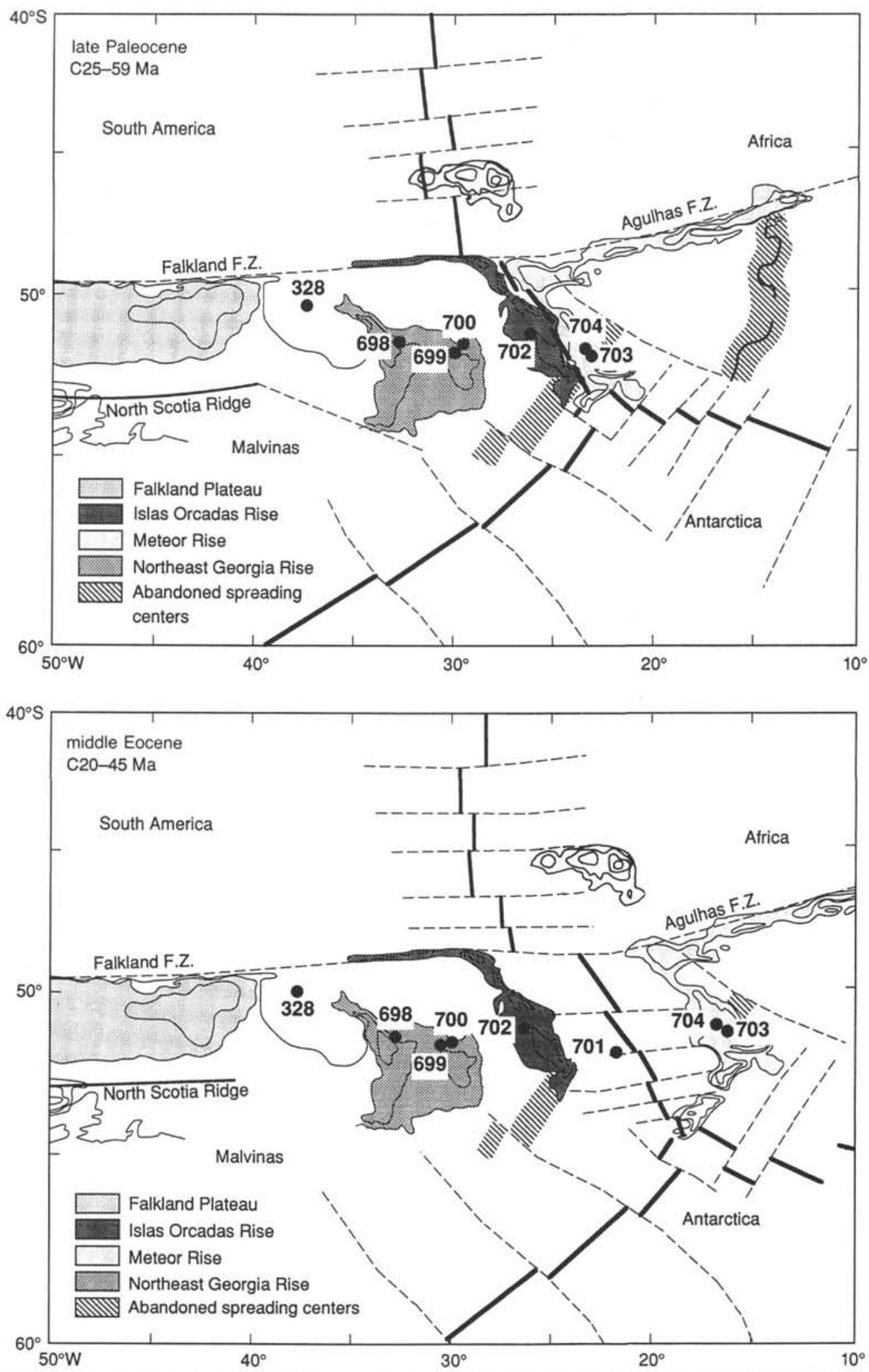

Figure 2. Reconstruction for the late Paleocene and middle Eocene with locations of Leg 114 drill sites. From OMD Region 13 synthesis (LaBrecque, 1986).

The specific objectives for Site 701 were:

to obtain a sediment record in the older portion of the deepwater gateway between the Islas Orcadas Rise and Meteor Rise to examine the deep-water exchange between antarctic and lower latitude water masses of the Atlantic; to document the development of the ACC and the southern high-latitude biosiliceous province;

to document the influence of the opening of the Drake Passage on the paleoceanography in the South Atlantic sector of the Southern Ocean; 


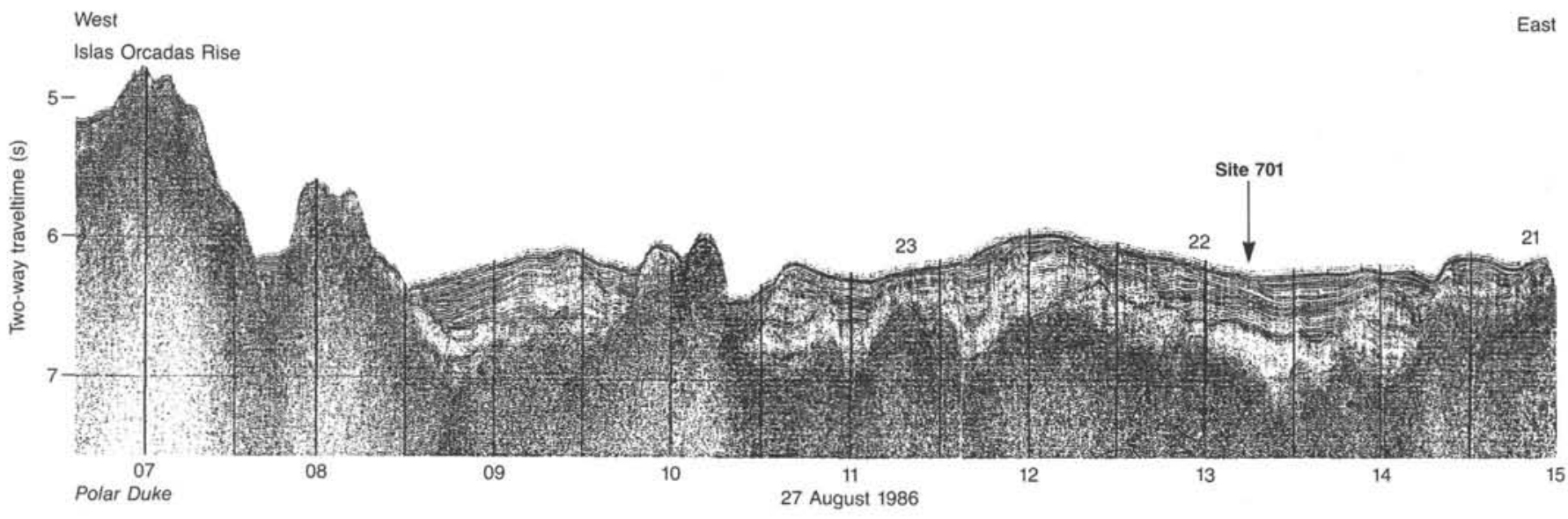

Figure 3. Single-channel seismic-reflection profile (Polar Duke cruise 0186) from Islas Orcadas Rise to Site 701. Position of magnetic anomalies (21, 22, and 23) indicated by their respective numbers. Profile location shown in Figure 1.

to determine what influence Neogene tectonic events in the Scotia Sea region had on deep-water circulation from the Weddell Sea and Pacific Ocean through this gateway into the South Atlantic;

to evaluate the Cenozoic evolution of latitudinal surface-water mass temperature gradients and what the influence was on the migration and evolution of planktonic biota;

to interpret the evolution of Paleogene vertical water-mass structure during the Paleogene;

to calibrate subantarctic microfossil zonal schemes and datums with the geomagnetic polarity time scale (GPTS);

to determine the age of basement to calibrate with the expected age based upon the anomaly pattern and thus confirm the age and rate of the initial spreading that formed the gateway.

The drilling plan for Site 701 called for two holes: Hole $701 \mathrm{~A}$ was to be cored with the APC to refusal, and Hole 701B was to repeat the sequence of Hole $701 \mathrm{~A}$ and core the remaining sequence to basement, using the APC and XCB systems. For basement penetration, the Navidrill system was to be deployed and tested. Two standard Schlumberger logging runs were planned using the stratigraphic and geochemical tools. Because of drilling problems, three holes were drilled recovering two complete sections with the APC/XCB systems to a depth of 202.46 $\mathrm{m}$ below seafloor (mbsf). Hole 701C extended beyond the total depths of Holes 701A and 701B to basement at $481.3 \mathrm{mbsf}$ where a flared XCB cutting shoe and damaged bit prevented further drilling. Logging was omitted because of poor hole conditions (see "Operations" section, this chapter).

\section{OPERATIONS}

Site 701 was located on Polar Duke line 0186 , about $6 \mathrm{nmi}$ east of the proposed site location (SA3A). This new location was based on a seismic sequence that appeared to be more laterally uniform than that observed at the originally designated location. The approach to the site and the geophysical survey were hampered by strong following seas. During the turn to position over the beacon, the ship rolled a hard $20^{\circ}$. By $1435 \mathrm{hr}, 4$ April, the vessel was operating in dynamic positioning mode, and the rig crew went to work.

After a slow, but safe, drill-string trip, Hole 701A was spudded at $0430 \mathrm{hr}, 5$ April (Table 1), and we began some eventful piston coring. Enormous swells, remnants of the storm we had just sailed through that were fed from a lingering low-pressure system hanging overhead, caused havoc with the piston coring operation. The second and third cores required two wireline trips to recover because the overshot shear pins failed. The pis- ton corer shear pins were consistently sheared during deployment as well, even when three pins were installed. One core barrel came up slightly bent, but operations continued amidst freezing temperatures and snow flurries. A decision to temporarily suspend coring operations might have been made if the forecast had not called for several days of the same weather conditions. Our only option was to continue coring. The hole was slowly deepened until Core 114-701A-8H. This core barrel jammed tightly downhole, and all efforts at freeing the barrel were unsuccessful. After shearing the overshot pin twice and trying all available options, the barrel showed no signs of coming loose. Therefore, the pipe was tripped back to the vessel. The bit cleared the mud line at $2225 \mathrm{hr}$ and was on deck at $0630 \mathrm{hr}, 6$ April. The reason for the stuck barrel turned out to be a shear pin stub wedged down beside the APC landing shoulder and the outer core barrel landing/saver sub. Apparently the stub had moved into this position after shearing during deployment.

Early that morning, while tripping pipe out of the hole, the seas again calmed and weather conditions allowed the transfer of the remaining ODP/SEDCO equipment from the Maersk Master. This included a fuel hose borrowed for refueling from the Sunny Trader, "yokohama" fenders that were used during the refueling, and the massive iceberg tow rope used during Leg 113 operations.

After offsetting the ship $10 \mathrm{~m}$ to the east, the pipe was again tripped to bottom, and Hole 701B was spudded at $1645 \mathrm{hr}, 6$ April. In an attempt to prevent or reduce the incidents experienced in Hole 701A, the APC shear pins were knurled and then peened to roughen the surface. These pins had to be installed with a hammer, and no more lost or partially protruding pins were experienced. In addition to eliminating the shear pin jamming potential, the sand line operators were told to significantly slow down in an attempt to minimize the surging and resultant cyclical loading on the overshot and APC shear pins. This technique seemed to help dramatically, and as operations continued in heavy swell conditions, the incidence of sheared overshot pins was greatly reduced.

During the early morning hours of 6 April, the Datasonics positioning beacon began acting erratically, and the signal degraded. We watched this condition closely because during the previous evening there had been times when we had temporarily lost acoustics, causing brief positioning problems. Thruster noise, interfering with the acoustic signal, proved to be a persistent nemesis throughout operations on this site. Although these particular problems did not reoccur after that night, by $0230 \mathrm{hr}$ the beacon was diagnosed as definitely defective, and a second bea- 
Table 1. Site 701 coring summary.

\begin{tabular}{ccccccc}
\hline $\begin{array}{c}\text { Core } \\
\text { no. }\end{array}$ & $\begin{array}{c}\text { Date } \\
\text { (Apr. 1987) }\end{array}$ & $\begin{array}{c}\text { Local } \\
\text { time } \\
(\mathrm{hr})\end{array}$ & $\begin{array}{c}\text { Depths } \\
(\mathrm{mbs})\end{array}$ & $\begin{array}{c}\text { Cored } \\
(\mathrm{m})\end{array}$ & $\begin{array}{c}\text { Recovered } \\
(\mathrm{m})\end{array}$ & $\begin{array}{c}\text { Recovery } \\
(\%)\end{array}$ \\
\hline Hole 701A: & & & & & & \\
& & & & & & \\
$1 \mathrm{H}$ & 5 & 0515 & $0.0-8.3$ & 8.3 & 8.30 & 100.0 \\
$2 \mathrm{H}$ & 5 & 0800 & $8.3-17.8$ & 9.5 & 10.10 & 106.3 \\
$3 \mathrm{H}$ & 5 & 1100 & $17.8-27.3$ & 9.5 & 9.64 & 101.0 \\
$4 \mathrm{H}$ & 5 & 1400 & $27.3-36.8$ & 9.5 & 5.44 & 57.2 \\
$5 \mathrm{H}$ & 5 & 1507 & $36.8-46.3$ & 9.5 & 9.47 & 99.7 \\
$6 \mathrm{H}$ & 5 & 1625 & $46.3-55.8$ & 9.5 & 9.98 & 105.0 \\
$7 \mathrm{H}$ & 5 & 1805 & $55.8-65.3$ & 9.5 & 7.10 & 74.7 \\
$8 \mathrm{H}$ & 6 & 0730 & $65.3-74.8$ & 9.5 & 9.63 & 101.0 \\
& & & & 74.8 & 69.66 & \\
& & & & & 74.8 &
\end{tabular}

Hole 701B:

$\begin{array}{llrrrrr}1 \mathrm{H} & 6 & 1910 & 70.0-79.5 & 9.5 & 9.67 & 102.0 \\ 2 \mathrm{H} & 6 & 2035 & 79.5-89.0 & 9.5 & 6.34 & 66.7 \\ 3 \mathrm{H} & 6 & 2205 & 89.0-98.5 & 9.5 & 8.50 & 89.5 \\ 4 \mathrm{H} & 7 & 0048 & 98.5-108.0 & 9.5 & 9.68 & 102.0 \\ 5 \mathrm{H} & 7 & 0210 & 108.0-117.5 & 9.5 & 9.52 & 100.0 \\ 6 \mathrm{H} & 7 & 0630 & 117.5-127.0 & 9.5 & 6.71 & 70.6 \\ 7 \mathrm{H} & 7 & 0900 & 127.0-136.5 & 9.5 & 8.77 & 92.3 \\ 8 \mathrm{H} & 7 & 1040 & 136.5-146.0 & 9.5 & 8.37 & 88.1 \\ 9 \mathrm{H} & 7 & 1230 & 146.0-155.5 & 9.5 & 7.62 & 80.2 \\ 10 \mathrm{H} & 7 & 1627 & 155.5-165.0 & 9.5 & 3.19 & 33.6 \\ 11 \mathrm{X} & 7 & 1810 & 165.0-174.5 & 9.5 & 0.11 & 1.2 \\ 12 \mathrm{X} & 7 & 1955 & 174.5-184.0 & 9.5 & 3.10 & 32.6 \\ 13 \mathrm{X} & 7 & 2240 & 184.0-193.5 & 9.5 & 5.82 & 61.2 \\ 14 \mathrm{X} & 7 & 2359 & 193.5-203.0 & 9.5 & 8.96 & 94.3\end{array}$

Hole 701C:

\begin{tabular}{|c|c|c|c|c|c|c|}
\hline $1 \mathrm{H}$ & 8 & 0330 & $0.0-6.3$ & 6.3 & 9.57 & 152.0 \\
\hline $2 \mathrm{H}$ & 8 & 0500 & $6.3-15.8$ & 9.5 & 8.70 & 91.6 \\
\hline $3 \mathrm{H}$ & 8 & 0630 & $15.8-25.3$ & 9.5 & 9.82 & 103.0 \\
\hline $4 \mathrm{H}$ & 8 & 0900 & $25.3-34.8$ & 9.5 & 9.97 & 105.0 \\
\hline $5 \mathrm{H}$ & 8 & 1030 & $34.8-44.3$ & 9.5 & 9.99 & 105.0 \\
\hline $6 \mathrm{H}$ & 8 & 1410 & $44.3-53.8$ & 9.5 & 9.61 & 101.0 \\
\hline $7 \mathrm{H}$ & 8 & 1540 & $53.8-63.3$ & 9.5 & 6.60 & 69.5 \\
\hline $8 \mathrm{H}$ & 8 & 1700 & $63.3-72.8$ & 9.5 & 10.06 & 105.9 \\
\hline $9 \mathrm{H}$ & 8 & 1845 & $72.8-82.3$ & 9.5 & 7.54 & 79.3 \\
\hline $10 \mathrm{H}$ & 8 & 1955 & $82.3-91.8$ & 9.5 & 8.86 & 93.2 \\
\hline $\mathrm{HIH}$ & 8 & 2140 & $91.8-101.3$ & 9.5 & 9.92 & 104.0 \\
\hline $12 \mathrm{H}$ & 8 & 2257 & $101.3-110.8$ & 9.5 & 5.29 & 55.7 \\
\hline $13 \mathrm{H}$ & 9 & 0040 & $110.8-120.3$ & 9.5 & 8.80 & 92.6 \\
\hline $14 \mathrm{H}$ & 9 & 0205 & $120.3-129.8$ & 9.5 & 8.89 & 93.6 \\
\hline $15 \mathrm{H}$ & 9 & 0320 & $129.8-139.3$ & 9.5 & 6.84 & 72.0 \\
\hline $16 \mathrm{H}$ & 9 & 0450 & $139.3-148.8$ & 9.5 & 9.42 & 99.1 \\
\hline $17 \mathrm{H}$ & 9 & 0620 & $148.8-158.3$ & 9.5 & 8.73 & 91.9 \\
\hline $18 \mathrm{H}$ & 9 & 0750 & $158.3-167.8$ & 9.5 & 2.54 & 26.7 \\
\hline $19 \mathrm{H}$ & 9 & 0925 & $167.8-177.3$ & 9.5 & 2.43 & 25.6 \\
\hline $20 \mathrm{H}$ & 9 & 1120 & $177.3-186.8$ & 9.5 & 8.32 & 87.6 \\
\hline $21 \mathrm{H}$ & 9 & 1255 & $186.8-196.3$ & 9.5 & 4.16 & 43.8 \\
\hline $22 \mathrm{H}$ & 9 & 1407 & $196.3-205.8$ & 9.5 & 9.73 & 102.0 \\
\hline $23 \mathrm{H}$ & 9 & 1516 & $205.8-215.3$ & 9.5 & 7.84 & 82.5 \\
\hline $24 \mathrm{H}$ & 9 & 1720 & $215.3-224.8$ & 9.5 & 9.88 & 104.0 \\
\hline $25 \mathrm{X}$ & 9 & 1945 & $224.8-234.3$ & 9.5 & 7.25 & 76.3 \\
\hline $26 \mathrm{X}$ & 9 & 2130 & $234.3-243.8$ & 9.5 & 2.01 & 21.1 \\
\hline $27 \mathrm{X}$ & 9 & 2257 & $243.8-253.3$ & 9.5 & 5.16 & 54.3 \\
\hline $28 \mathrm{X}$ & 10 & 0045 & $253.3-262.8$ & 9.5 & 0.61 & 6.4 \\
\hline $29 \mathrm{X}$ & 10 & 0220 & $262.8-272.3$ & 9.5 & 9.59 & 101.0 \\
\hline $30 \mathrm{X}$ & 10 & 0330 & $272.3-281.8$ & 9.5 & 0.50 & 5.3 \\
\hline $31 x$ & 10 & 0450 & $281.8-291.3$ & 9.5 & 8.90 & 93.7 \\
\hline $32 \mathrm{X}$ & 10 & 0610 & $291.3-300.8$ & 9.5 & 9.24 & 97.2 \\
\hline $33 \mathrm{X}$ & 10 & 0815 & $300.8-310.3$ & 9.5 & 0.37 & 3.9 \\
\hline $34 \mathrm{X}$ & 10 & 0920 & $310.3-319.8$ & 9.5 & 9.53 & 100.0 \\
\hline $35 \mathrm{X}$ & 10 & 1020 & $319.8-329.3$ & 9.5 & 9.59 & 101.0 \\
\hline $36 \mathrm{X}$ & 10 & 1130 & $329.3-338.8$ & 9.5 & 2.25 & 23.7 \\
\hline $37 x$ & 10 & 1300 & $338.8-348.3$ & 9.5 & 6.28 & 66.1 \\
\hline $38 \mathrm{X}$ & 10 & 1535 & $348.3-357.8$ & 9.5 & 3.96 & 41.7 \\
\hline $39 \mathrm{X}$ & 10 & 1700 & $357.8-367.3$ & 9.5 & 0.48 & 5.1 \\
\hline $40 \mathrm{X}$ & 10 & 1835 & $367.3-376.8$ & 9.5 & 0.12 & 1.3 \\
\hline $41 X$ & 10 & 1950 & $376.8-386.3$ & 9.5 & 5.40 & 56.8 \\
\hline $42 X$ & 10 & 2155 & $386.3-395.8$ & 9.5 & 2.12 & 22.3 \\
\hline $43 \mathrm{X}$ & 10 & 2312 & $395.8-405.3$ & 9.5 & 9.73 & 102.0 \\
\hline $44 X$ & 11 & 0030 & $405.3-414.8$ & 9.5 & 9.68 & 102.0 \\
\hline $45 \mathrm{X}$ & II & 0140 & $414.8-424.3$ & 9.5 & 9.59 & 101.0 \\
\hline $46 x$ & 11 & 0310 & $424.3-433.8$ & 9.5 & 4.87 & 51.2 \\
\hline $47 \mathrm{X}$ & 11 & 0425 & $433.8-443.3$ & 9.5 & 9.69 & 102.0 \\
\hline $48 \mathrm{X}$ & 11 & 0545 & $443.3-452.8$ & 9.5 & 0.26 & 2.7 \\
\hline $49 \mathrm{X}$ & 11 & 0700 & $452.8-462.3$ & 9.5 & 8.57 & 90.2 \\
\hline $50 \mathrm{X}$ & 11 & 0840 & $462.3-471.8$ & 9.5 & 1.66 & 17.5 \\
\hline \multirow[t]{2}{*}{$51 x$} & 11 & 1135 & $471.8-481.3$ & 9.5 & 0.14 & 1.5 \\
\hline & & & & 481.3 & 331.06 & \\
\hline
\end{tabular}

con was dropped to the seafloor as a backup. At $0330 \mathrm{hr}$ the vessel began positioning on the new beacon. Weather conditions began moderating toward the end of operations at Hole 701B. Hole $701 \mathrm{~B}$ was terminated at $203 \mathrm{mbsf}$.

After offsetting the ship $10 \mathrm{~m}$ to the northeast, Hole $701 \mathrm{C}$ was spudded at $0230 \mathrm{hr}, 8$ April 1987 . Operating conditions for Hole $701 \mathrm{C}$ were among the best experienced during the cruise. Our perspective had evolved to consider $20-30$-kt winds and $10-$ 15 - $\mathrm{ft}$ seas to be good conditions for this time of year in the South Atlantic.

The first day of piston coring operations at Hole 701C went extremely well, coring nearly $111 \mathrm{~m}$ with $95 \%$ plus recovery. Core quality was good and spirits were high. Exceptionally good performance from all coring systems continued for the next two days. The much-improved weather conditions were a significant factor in the high quality of the operations. In an effort to maintain good hole conditions and thereby avoid a recurrence of the previously experienced failures, a program of spotting high-viscosity mud pills was initiated. This appeared to be working quite well as several coarse sand and gravel layers were penetrated without any significant hole problems or fill encountered.

With the recovery of Core 114-701C-51X, from $481 \mathrm{mbsf}$, the situation changed. The cutting shoe on this barrel was severely worn. The check valve seat was found in the barrel and the ball was missing. The driller acknowledged that a very hard layer had been encountered approximately $2 \mathrm{~m}$ in on this core run. The resistant formation was approximately $1 \mathrm{~m}$ thick and required $45 \mathrm{~min}$ to penetrate. Earlier cores had been cut at 35 strokes per minute (spm), with $10,000-18,000$-lb weight on bit and $400-500$-psi pump pressure. This core was cut with 18,000 $\mathrm{lb}$ weight on bit but with $50 \mathrm{spm}$ and 600 -psi pressure recorded. Immediately below this layer, the formation appeared to become softer again. Some torquing was experienced, and recovery in the barrel was a mere $0.14 \mathrm{~m}$. Another XCB system barrel was deployed to core into the softer material and see if we had possibly broken through a sill or massive chert layer into sediment. Attempts at getting back down the original hole to total depth were fruitless. The uppermost hard layer was penetrated, but approximately $4 \mathrm{~m}$ off bottom all progress was halted. The drill string began to torque up, and the barrel was found to be securely stuck. All efforts to recover the barrel were unsuccessful. Again, efforts to reach basement and deploy the prototype Navidrill coring system were thwarted.

Because the hole was reasonably stable while drilling, we decided to pull above the zone that had caused sticking problems at the bottom (approximately $23 \mathrm{~m}$ ) and then log through the pipe. Only one suite of tools could be run, and we anticipated that this would take approximately $12 \mathrm{hr}$. While pulling up to the logging point and rigging the sheaves the pipe became stuck above the drilling jars. After $15 \mathrm{~min}$ of working the pipe and circulating, the drill string was freed; however, we decided that it would be unwise to attempt logging through the pipe under these circumstances. The logging tools were rigged down, the hole was filled with weighted mud, and the pipe was tripped out of the hole. At $2115 \mathrm{hr}$ the bit cleared the rotary table. The bit was found to be missing one cone, and the other cones were severely damaged with most inserts either broken or missing. The $\mathrm{XCB}$ wash barrel was in place, but retrieval was impossible because the cutting shoe was flared. After using a torch to cut off the damaged XCB shoe, the barrel was retrieved and put aside so the vessel could get underway for the next site at $0745 \mathrm{hr}$. We made a pass over the beacon to supplement the poor geophysical records obtained during the rough weather upon arrival at Site 701. Four hours were required to remove the core liner from the damaged core barrel. A large chunk of basalt was found wedged inside the core liner, which indicated that the hole had 
indeed bottomed in basement or in a volcanic sill overlying basement.

\section{LITHOSTRATIGRAPHY}

Three holes were drilled at Site 701 in middle Eocene oceanic crust (anomaly 22) on the western flank of the Mid-Atlantic Ridge. At Hole 701A, 74.8 m of lower Pliocene and Quaternary sediment was penetrated $(93.13 \%$ recovery). At Hole $701 \mathrm{~B}$, a total of $203 \mathrm{~m}$ of sediment, ranging in age from late Miocene to Quaternary, was penetrated $(72.45 \%$ recovery). Hole $701 \mathrm{C}$ was drilled to 481.3 mbsf, recovering $331 \mathrm{~m}(66.8 \%)$ of middle Eocene to Quaternary sediment.

The stratigraphic sequence at Site 701 is divided into four units based on compositional changes in lithology (Fig. 4 and Table 2). Holes $701 \mathrm{~A}$ and $701 \mathrm{~B}$ penetrated only Unit I, whereas Hole $701 \mathrm{C}$ recovered Units I through IV.

Unit I consists predominately of a diatom ooze with varying admixtures of clay, mud, and volcanic ash (Fig. 5). It is further divided into four subunits on the basis of pronounced lithologic and paleontologic changes that are related to paleoenvironmental events. Subunit IA consists of an ash-bearing and/or mudbearing diatom ooze with discrete ash horizons and dispersed ash throughout. Lithic clasts are embedded in the diatom ooze and probably represent dropstones of ice-rafted origin. Subunit IB is a pure diatom ooze composed of a nearly monospecific assemblage of a warm-temperate to tropical diatom, Bruniopsis mirabilis. The Bruniopsis ooze is organic-carbon-rich $(0.55 \%)$, finely laminated, lacking bioturbation, and pyritic. Subunit IC is a sand/gravel horizon that appears within the Bruniopsis ooze. Subunit ID consists of a clay-bearing diatom ooze with a typical subantarctic diatom assemblage.

The transition from Units I to II is marked by a change from clay-bearing diatom ooze to diatom-bearing mud and by a decrease in the importance of volcanic ash. Subunit IIA is composed solely of siliceous clay and mud, whereas Subunit IIB is characterized by an admixture of siliceous microfossils, nannofossils, and clay in varying proportions.

Unit III consists entirely of indurated nannofossil chalk directly overlying basement. Unit IV consists of a single, $8-\mathrm{cm}-$ long piece of amygdaloidal olivine basalt that was retrieved from the last core barrel. It is uncertain whether this basalt represents oceanic basement or a sill.

\section{Hole 701A}

\section{Subunit IA (upper part): Core 114-701A-1H to Section 114-701A-8H, CC; Depth: 0-74.8 mbsf; Age: late Pliocene to Quaternary.}

Subunit IA consists of alternating horizons of ash-bearing diatom ooze, mud-bearing diatom ooze, muddy diatom ooze, and diatom ooze. Numerous subtle color changes reflect the relative importance of ash, mud, and diatoms. Ash horizons tend to be dark gray $(5 \mathrm{Y} 4 / 1, \mathrm{~N} 4 /)$, very dark gray $(7.5 \mathrm{YR} 3 / 1)$, greenish gray ( $5 \mathrm{G} 4 / 1)$, and olive gray ( $5 \mathrm{Y} 5 / 3$ ). Mud-bearing horizons are greenish gray (5GY $5 / 1,6 / 1 ; 5 G 4 / 1,4 / 2,5 / 1,5$ / 2 ). Diatom oozes are olive gray ( $5 Y 5 / 2,5 / 3,6 / 2)$, gray (5Y $5 /$ $1)$, and light yellowish brown (2.5Y 6/4).

Discrete ash horizons, thicker than several centimeters, occur at the following horizons: $52-62 \mathrm{~cm}$ in Section 114-701A-1H-4, $14-21 \mathrm{~cm}$ in Section 114-701A-2H-4, 53-56 cm in Section 114701A-2H-6, and 122-130 cm in Section 114-701A-3H-5.

Dropstones and ice-rafted detritus of varying lithologies (greenschist, quartzites, etc.) are found throughout the section. Mottling, resulting from bioturbation, is very diffuse through- out Hole 701A. As has been observed in virtually all Leg 114 APC cores, the top part of the first section of each core is usually marked by soupy drilling disturbance.

\section{Hole 701B}

Subunit IA (lower part): Core 114-701B-1H to Sample 114701B-9H-2, $26 \mathrm{~cm}$; Depth: 70.0-147.5 mbsf; Age: late Miocene to late early Pliocene.

Hole $701 \mathrm{~B}$ was washed down to $70 \mathrm{~m}$ to avoid repeating the entire top part of Hole 701A. Subunit IA consists of alternating horizons of ash-bearing diatom ooze, mud-bearing diatom ooze, clay-bearing diatom ooze, and diatom ooze. These compositional changes are reflected in subtle alternating color bands of greenish gray (5GY $5 / 1,6 / 1 ; 5 G 5 / 1,6 / 1 ; 5 B G 5 / 1)$, olive gray (5Y $5 / 2)$, dark blue gray (5B 4/1), and gray (5Y 5/1).

Discrete ash horizons are found at the following horizons: $85-87 \mathrm{~cm}$ in Section 114-701B-1H-2, 85-92 cm in Section 114$701 \mathrm{~B}-3 \mathrm{H}-4,132-138 \mathrm{~cm}$ in Section 114-701B-6H-1, 25-26 cm in Section 114-701B-6H-3, 85-86 cm in Section 114-701B-6H-4, and $88-89 \mathrm{~cm}$ in Section 114-701B-6H-4.

Small and large lithic fragments, interpreted to be of icerafted origin, occur throughout Subunit IA. Bioturbation is faint but pervasive throughout the section.

\section{Subunit IB: Samples 114-701B-9H-2, $26 \mathrm{~cm}$, to 114-701B-} 12X-1, $26 \mathrm{~cm}$; Depth: 147.5-174.76 mbsf; Age: late Miocene.

Subunit IB is composed mainly of a monospecific assemblage of a tropical to temperate diatom, Bruniopsis mirabilis. The thermophilic silicoflagellate Dictyocha is also present in high abundance in this subunit. This Bruniopsis ooze also contains minor amounts of other diatoms, radiolarians, pyrite, clay, quartz, feldspar, and volcanic ash. Although Subunit IB is $27.26 \mathrm{~m}$ thick, only $11.15 \mathrm{~m}(40.9 \%)$ of Bruniopsis ooze was obtained because of poor core recovery. Drilling disturbance in Hole 701B has blurred some of the original fine structure of the sediment, but traces of fine lamination remain. Alternating light and dark laminae are several millimeters thick, with no evidence of bioturbation. The dark horizons are rich in pyrite, which coats radiolarian tests and diatom frustules. Organic carbon analyses of this unit give values of $0.5 \%-0.6 \%$ organic carbon within the Bruniopsis ooze, in comparison to background levels of $0.1 \%-0.2 \%$ (Fig. 6). Bioturbation is conspicuously absent from this subunit in comparison with the typical diatom oozes of Subunits IA and IC.

Subunit IC: Samples 114-701B-12X-1, $26 \mathrm{~cm}$, to 114-701B12X, CC (21 cm); Depth: 174.76-183.71 mbsf; Age: late Miocene.

Subunit IC consists of moderately to well-sorted sand and gravel of varying lithologies, including quartz, volcanic glass, agglutinated benthic foraminifers, biotite, metapelites, iron-coated schists, pumice, and mud clasts. These components are subrounded to subangular and contain interbedded clasts of diatom ooze. The sand/gravel unit is normally graded, with gravels at the base and coarse sand at the top. Because the core barrel was partially filled upon recovery, it is uncertain whether the grading reflects gravity sedimentation or is an artifact of sorting.

The precise stratigraphic position of this subunit is uncertain because of poor core recovery (Fig. 6). At Hole 701B, the sand/ gravel unit is $2.85 \mathrm{~m}$ thick and is overlain by Bruniopsis ooze and underlain by diatom ooze containing a typical subantarctic assemblage. The contact between the sand/gravel and overlying 


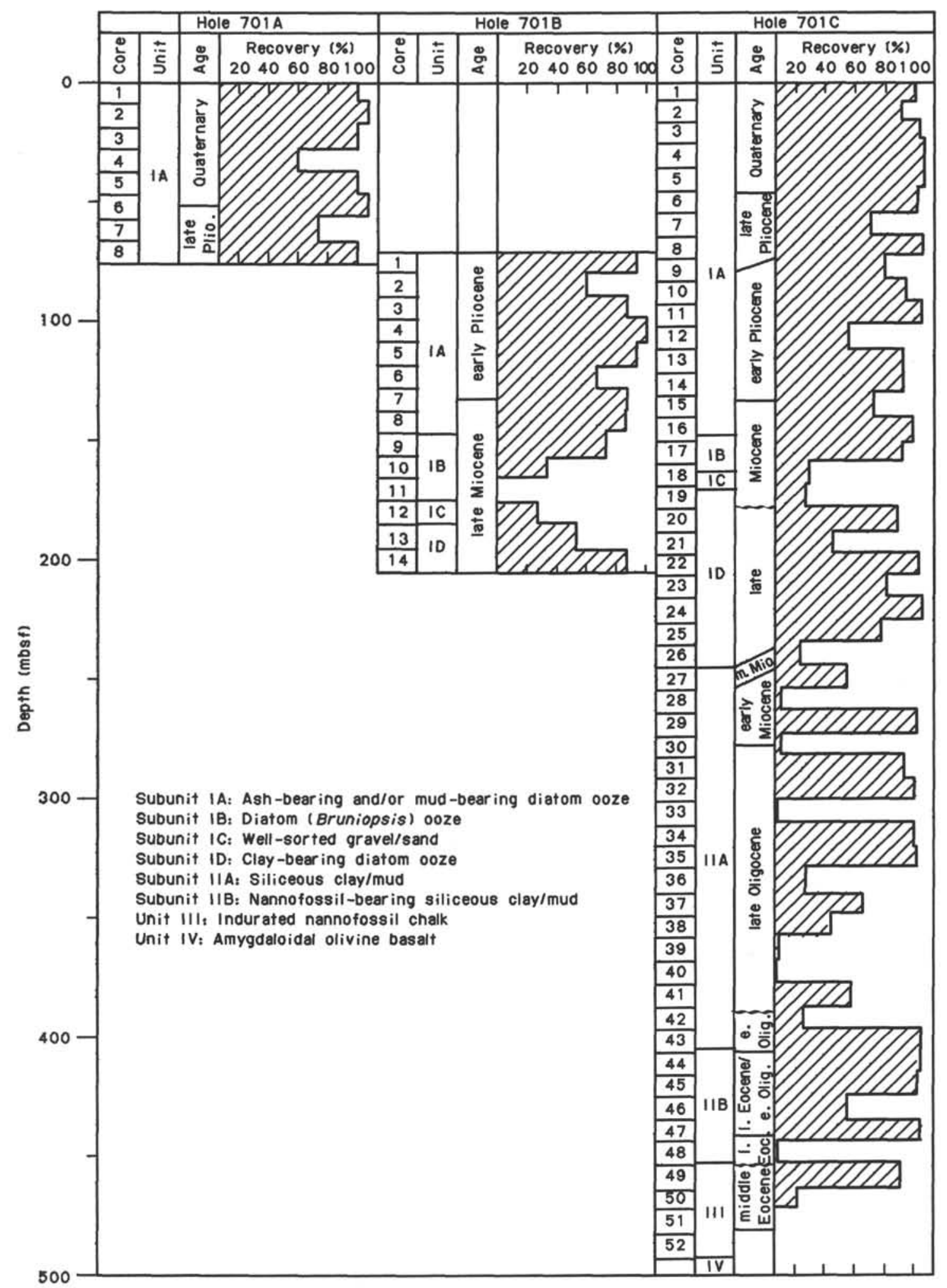

Figure 4. Recovery, lithostratigraphic units, and ages for Holes 701A, 701B, and 701C.

Bruniopsis ooze is disturbed, consisting of $43 \mathrm{~cm}$ of a slurry of Bruniopsis ooze and sand. Clasts of diatom ooze are also contained within the sand/gravel unit. The base of the subunit occurs in the core catcher of Core 114-701B-12X and is marked by a sharp contact between gravel and diatom ooze containing a typical subantarctic assemblage.
Subunit ID: Sample 114-701B-12X, CC $(21 \mathrm{~cm})$ to Section 114-701B-14X, CC; Depth: 183.71-203.0 mbsf; Age: late Miocene.

At Hole 701B, Subunit ID consists of diatom ooze and claybearing diatom ooze. The color of the diatom ooze alternates 
Table 2. Lithostratigraphic units at Site 701.

\begin{tabular}{|c|c|c|c|c|}
\hline Hole & $\begin{array}{c}\text { Unit/ } \\
\text { subunit }\end{array}$ & Interval & $\begin{array}{l}\text { Depth } \\
\text { (mbsf) }\end{array}$ & Age \\
\hline $701 \mathrm{~A}$ & IA & $1 \mathrm{H}$ to $8 \mathrm{H}, \mathrm{CC}$ & $0-74.8$ & late Pliocene to Quaternary \\
\hline \multirow[t]{4}{*}{$701 \mathrm{~B}$} & IA & $1 \mathrm{H}$ to $9 \mathrm{H}-2,26 \mathrm{~cm}$ & $70.0-147.5$ & late Miocene to early Pliocene \\
\hline & IB & $9 \mathrm{H}-2,26 \mathrm{~cm}$, to $12 \mathrm{X}-1,26 \mathrm{~cm}$ & $147.5-174.76$ & late Miocene \\
\hline & IC & $12 \mathrm{X}-1,26 \mathrm{~cm}$, to $12 \mathrm{X}, \mathrm{CC}(21 \mathrm{~cm})$ & $174.76-183.71$ & late Miocene \\
\hline & ID & $12 \mathrm{X}, \mathrm{CC}(21 \mathrm{~cm})$ to $14 \mathrm{X}, \mathrm{CC}$ & $183.71-203.00$ & late Miocene \\
\hline \multirow[t]{8}{*}{$701 C$} & IA & $1 \mathrm{H}-1$ to $16 \mathrm{H}-5,20 \mathrm{~cm}$ & $0-145.5$ & late Miocene to Quaternary \\
\hline & IB & $16 \mathrm{H}-5,20 \mathrm{~cm}$, to $18 \mathrm{H}-2,110 \mathrm{~cm}$ & $145.5-160.9$ & late Miocene \\
\hline & IC & $18 \mathrm{H}-2,110 \mathrm{~cm}$, to $19 \mathrm{H}-1,16 \mathrm{~cm}$ & $160.9-167.96$ & late Miocene \\
\hline & ID & $19 \mathrm{H}-1,16 \mathrm{~cm}$, to $27 \mathrm{X}-1$ & $167.96-243.8$ & late Miocene \\
\hline & IIA & $27 X-1$ to $43 X-6,135 \mathrm{~cm}$ & $243.8-395.15$ & early to middle Miocene \\
\hline & IIB & $43 \mathrm{X}-6,135 \mathrm{~cm}$, to $49 \mathrm{X}-1$ & $395.15-452.8$ & late Eocene to early Oligocene \\
\hline & III & $49 \mathrm{X}-1$ to $52 \mathrm{~W}, \mathrm{CC}$ & $452.8-481.3$ & middle Eocene \\
\hline & IV & $52 \mathrm{~W}, \mathrm{CC}$ & $481.3-481.47$ & \\
\hline
\end{tabular}

in subtle bands of greenish gray (5GY $6 / 1 ; 5 G 5 / 2,6 / 1 ; 5 B G$ $5 / 1,6 / 1)$ and gray $(\mathrm{N} 5 / 0)$. The diatom assemblage is composed of subantarctic species, and diffuse bioturbation is prevalent throughout. Gravels occur as downhole contaminants in the first sections of Cores 114-701B-13X and 114-701B-14X.

\section{Hole 701C}

Subunit IA: Section 114-701C-1H-1 to Sample 114-701C16H-5, $20 \mathrm{~cm}$; Depth: 0-145.5 mbsf; Age: late Miocene to Quaternary.

At Hole 701C, Subunit IA is similar to that described previously in Holes 701A and 701B. This subunit includes the following lithologies: diatom ooze, mud-bearing diatom ooze, muddy diatom ooze, and ash-bearing diatom ooze. Subtle gradational color changes occur throughout the section, mainly reflecting the ash content of the sediment. Color variations include brown $(2.5 \mathrm{Y} 5 / 4)$, olive gray $(5 \mathrm{Y} 4 / 2,5 / 3,6 / 2,6 / 3)$, gray $(5 \mathrm{Y} 5 / 1)$, and bluish gray (5B 5/1). Discrete ash horizons are gray (N6/), dark gray (5Y 4/1), very dark gray (5Y $3 / 10)$, or black (5Y $2.5 / 1)$.

Subunit IA contains persistent evidence of high volcanic activity throughout the section in the form of dispersed ash, which imparts a darker hue to the sediment. Discrete ash horizons measure $1-10 \mathrm{~cm}$, and some ash has been altered to a green (5G 5/2) clay mineral, possibly montmorillonite. Discrete ash layers occur at the following horizons: $129-135 \mathrm{~cm}$ in Section 114-701C-1H-6, 103-109 cm in Section 114-701C-3H-4, 68-73 $\mathrm{cm}$ in Section 114-701C-4H-2, 135-140 cm in Section 114-701C$4 \mathrm{H}-2,117-119 \mathrm{~cm}$ in Section $114-701 \mathrm{C}-8 \mathrm{H}-5$, and $68-70 \mathrm{~cm}$ in Section 114-701C-9H-1.

Bioturbation is diffuse but prevalent throughout the section and includes mainly Planolites and minor Chondrites. Ice-rafted lithic fragments are sporadically distributed throughout Unit I, but some occurrences may be due to downhole contamination. A manganese nodule occurs at $65 \mathrm{~cm}$ in Section 114-701C-10H-2.

Drilling disturbance is evident in the first section of most cores.

\section{Subunit IB: Samples 114-701C-16H-5, $20 \mathrm{~cm}$, to 114-701C-} $18 H-2,110 \mathrm{~cm}$; Depth: 145.5-160.9 mbsf; Age: late Miocene.

Subunit IB consists of $14.7 \mathrm{~m}$ of diatom ooze dominated by Bruniopsis mirabilis (Fig. 7). The Bruniopsis ooze is very finely laminated (millimeter range) with rhythmic alternations of light (pale olive, 5Y 6/3) and dark (dark gray, N4/) varvelike horizons. The light horizons consist predominantly of Bruniopsis mirabilis. Other horizons are rich in radiolarians, pyrite, quartz/ feldspars, or the silicoflagellate Dictyocha. The dark horizons are rich in pyrite-coated microfossils, particularly radiolarians. The mean percent organic carbon content of the Bruniopsis ooze is about $0.5 \%$, which is significantly greater than background levels (Fig. 8). Bioturbation is conspicuously absent in this subunit.

In Sample 114-701C-17H, 48-51 cm, a thin, 3-cm sand horizon was noted that consists of mainly quartz and feldspar. Similar thin, quartz- and feldspar-rich horizons occur within the Bruniopsis ooze.

Subunit IC: Samples 114-701C-18H-2, $110 \mathrm{~cm}$, to 114-701C19H-1, $16 \mathrm{~cm}$; Depth: 160.9-167.96 mbsf; Age: late Miocene.

At Hole $701 \mathrm{C}$, Subunit IC consists of $16 \mathrm{~cm}$ of sand/gravel (Fig. 9). The lithology of the sand/gravel is identical to that recovered in Hole 701B, but the subunit is much thinner. Lithologies and constituents include quartz, volcanic glass, agglutinated benthic foraminifers, biotite, metapelites, iron-coated schists, pumice, and mud clasts. The sand/gravel unit in Hole $701 \mathrm{C}$ is overlain by $14.7 \mathrm{~m}$ of Bruniopsis ooze and underlain by an additional $2.24 \mathrm{~m}$ of Bruniopsis ooze (Fig. 8). The contact between the sand/gravel and the underlying Bruniopsis ooze is disturbed.

\section{Subunit ID: Sample 114-701C-19H-1, $16 \mathrm{~cm}$, to Section 114-701C-27X-1; Depth: 167.96-243.8 mbsf; Age: middle to late Miocene.}

The top $2.24 \mathrm{~m}$ of Subunit ID is composed of Bruniopsis ooze, whereas the remaining $75.8 \mathrm{~m}$ of Subunit ID is a thick sequence of clay- or mud-bearing diatom ooze of middle to late Miocene age. Colors range from olive $(5 \mathrm{Y} 5 / 3,6 / 3)$ to greenish gray $(5 G Y 5 / 1,6 / 1)$, gray $(5 G Y 5 / 1,6 / 1)$ and to dark blue gray (5B 4/1). Volcanic ash occurs as discrete and disseminated horizons, and some ash has been altered to green (5G 5/2) clay. Ash layers are typically gray $(\mathrm{N} 5 /, 6 /)$, dark gray $(5 \mathrm{Y} 3 / 1)$, or black (7.5YR 2/0).

Bioturbation is diffuse throughout, resulting in sediment mottling. Planolites dominates the ichnofauna, and Zoophycos first appears at 37-47 cm in Section 114-701C-23H-3.

A manganese nodule occurs in Sample 114-701C-23H-3, 104 $\mathrm{cm}$, with evidence of purple (5B 4/1) alteration and staining in the surrounding sediment (Fig. 10). A vertical synsedimentary fracture occurs in Sample 114-701C-25X-4, $130 \mathrm{~cm}$. Toward the base of Subunit ID, reworked nannofossils begin to appear in the first three sections of Core 114-701C-26X.

Subunit IIA: Section 114-701C-27X-1 to Sample 114-701C43X-6, $135 \mathrm{~cm}$; Depth: 243.8-395.15 mbsf; Age: early-middle Miocene.

Subunit IIA consists of diatom-bearing mud/clay, siliceousbearing mud/clay, and siliceous mud/clay. Throughout the subunit, fine-grained terrigenous clays dominate over biogenic siliceous components. Color hues vary considerably and include 


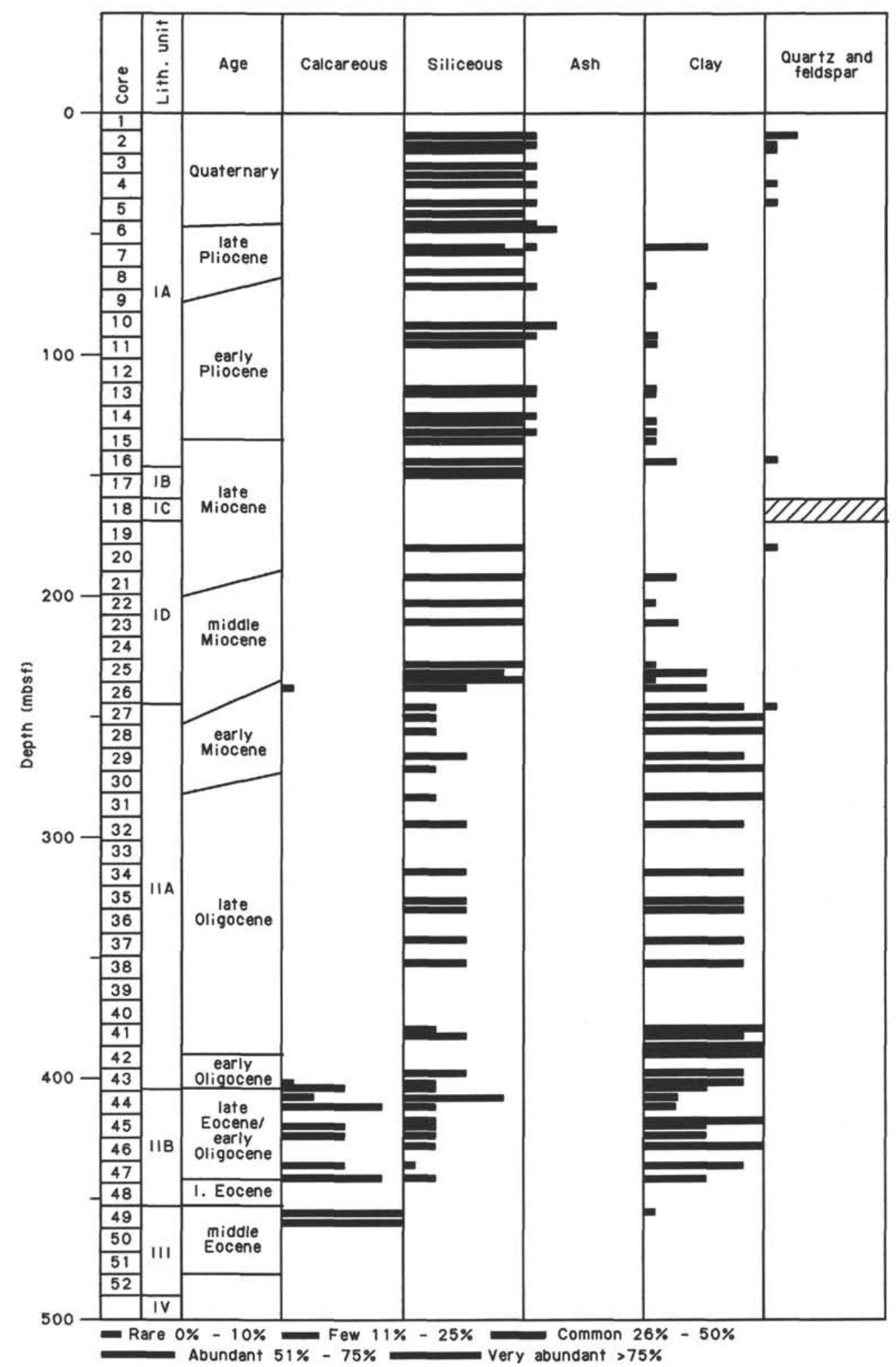

Figure 5. Relative abundance of calcareous, siliceous, ash, clay, and quartz components at Site 701, based on smear slide analysis.

grayish green (5G 5/2), greenish gray ( 5 GY $5 / 1,6 / 1)$, olive gray (5Y $5 / 2)$, gray $(5 \mathrm{Y} 4 / 1,5 / 1)$, and brown (5YR $5 / 4)$.

Grayish green (5G 4/2) altered ash horizons occur throughout the subunit. Other minor lithologies include iron-manganese oxides and lithic fragments representing downhole contamination. Bioturbation is faint to moderate.
Subunit IIB: Sample 114-701C-43X-6, $135 \mathrm{~cm}$, to Section 114-701C-49X-1; Depth: 395.15-452.8 mbsf; Age: late Eocene to early Oligocene.

Subunit IIB is marked by alternations of three components: nannofossil ooze, siliceous ooze, and clay. This subunit repre- 


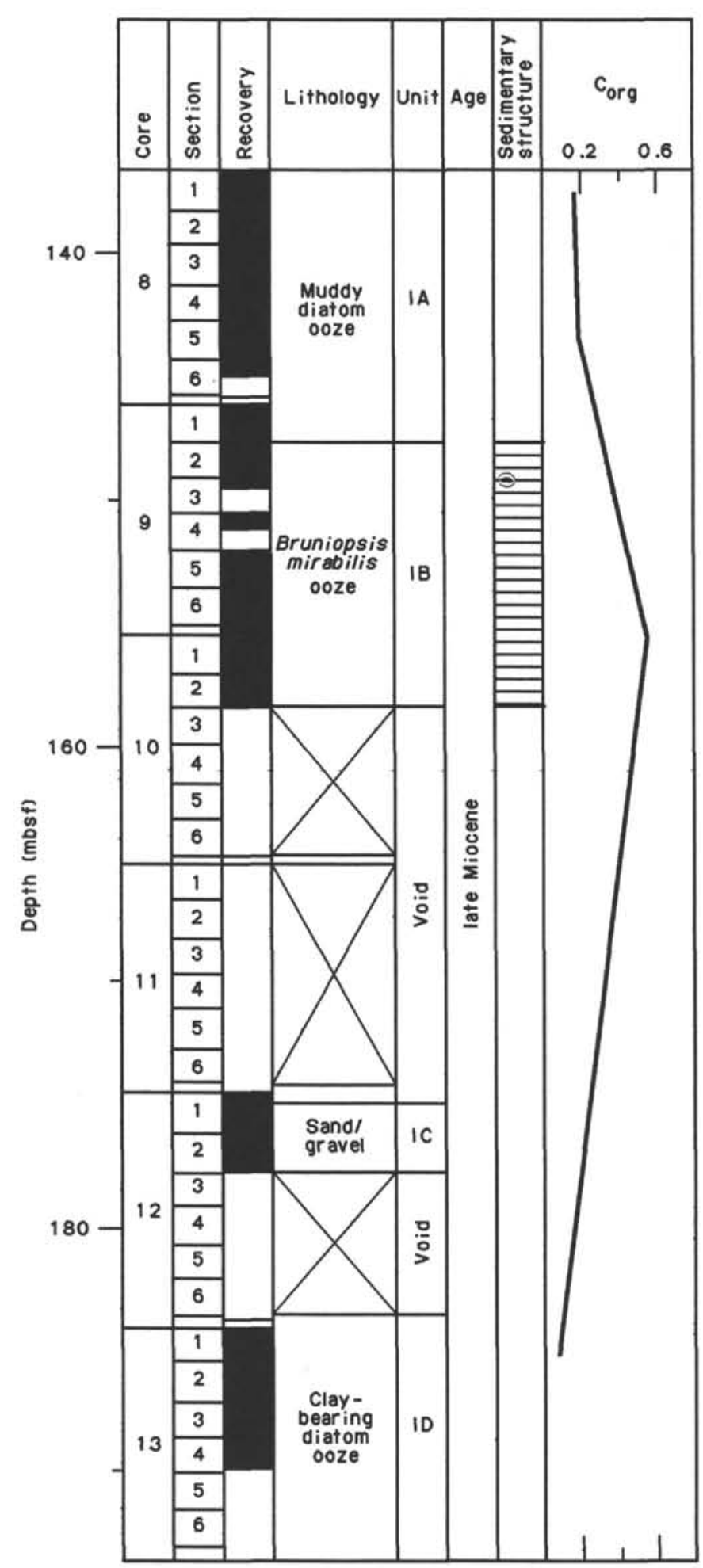

Figure 6. Detailed stratigraphic section for Subunits IA (Bruniopsis ooze) and IB (sand/gravel) in Hole 701B. Note the lamination, lack of bioturbation, and high organic content in the Bruniopsis ooze. The sand/gravel subunit (IC) is approximately $3 \mathrm{~m}$ thick in Hole 701B.

sents the first consistent appearance of carbonate sediment at Site $701 \mathrm{C}$, as shown by an increase in carbonate content at about 400 mbsf (Fig. 11). Major lithologies include siliceous clay, nannofossil-siliceous-bearing clay, siliceous-bearing clayey nannofossil ooze, and nannofossil-bearing clayey siliceous ooze.

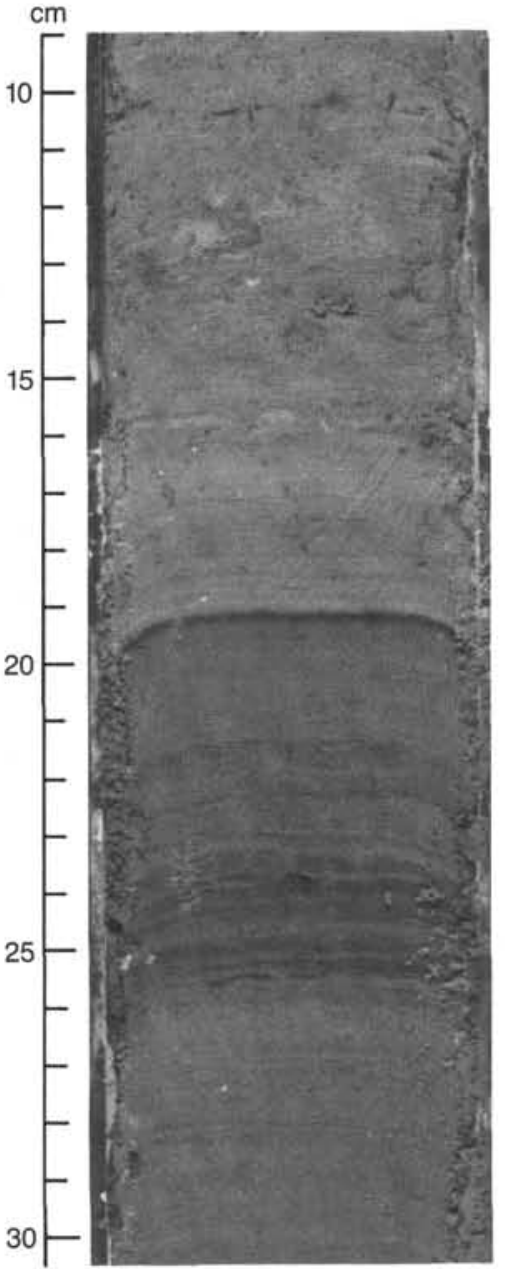

Figure 7. Contact at about $16-17 \mathrm{~cm}$ between the clay-bearing diatom ooze of Subunit IA and the Bruniopsis ooze of Subunit IB (Sample 114 $701 \mathrm{C}-16 \mathrm{H}-5,9-30 \mathrm{~cm})$. There is a marked contrast between bioturbated Subunit IA and finely laminated Subunit IB. The darker colored bands in Subunit IB contain a high concentration of pyrite.

Colors range from grayish brown (2.5Y 5/2), light brownish gray $(2.5 Y 6 / 2)$, greenish gray $(5 G 5 / 2,6 / 1 ; 5 G Y 7 / 1)$, to light blue gray (5BG 7/1). Bioturbation is markedly intensified in this subunit, causing mottling of lighter and darker color shades. Planolites and Zoophycos dominate the ichnofauna.

Unit III: Sections 114-701C-49X-1 to 114-701C-52X, CC; Depth: 452.8-481.3 mbsf; Age: middle Eocene.

Unit III consists of white (no color code) to light brownish gray $(2.5 \mathrm{Y} 6 / 2)$ indurated nannofossil chalk with intermittent dark brown (10YR 3/3) staining of carbonate, probably by iron manganese oxides. The carbonate content of this unit averages $80 \%$, which represents a marked increase in comparison to other lithostratigraphic units (Fig. 10). This unit directly overlies basalt, and the alteration and staining of carbonate probably result from diagenetic reactions with the underlying oceanic crust. This unit is dated as middle Eocene.

Unit IV: Section 114-701C-52W, CC; Depth: 481.3-481.47 mbsf.

Unit IV consists of a single piece of highly-altered amygdaloidal olivine basalt, dark blue gray (5B 4/1) in color, that represents oceanic crustal basement or possibly an interbedded sill. The sample comes from a wash core through the interval cored 


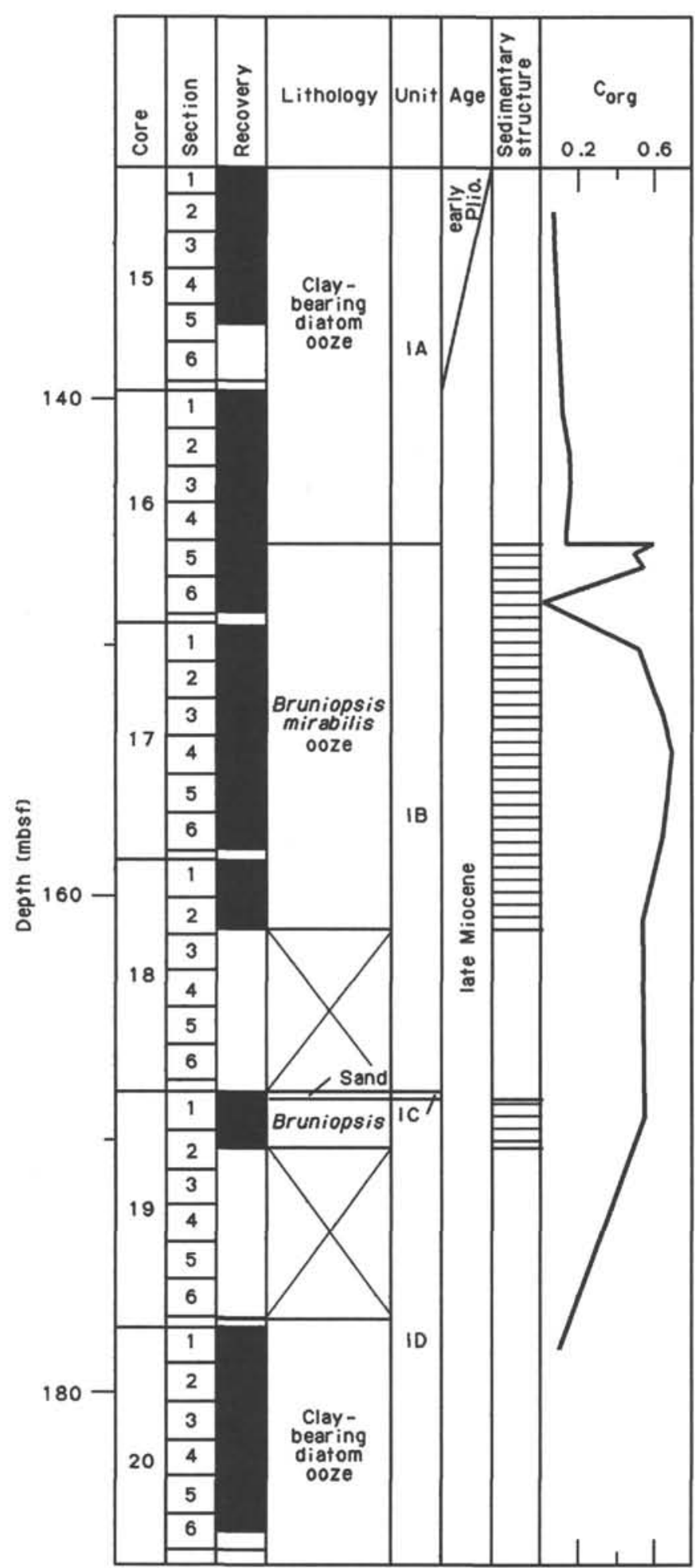

Figure 8. Detailed stratigraphic section for Subunits IA (Bruniopsis ooze) and IB (sand/gravel) in Hole 701C. Note the lamination, lack of bioturbation, and high organic content in the Bruniopsis ooze. The sand/gravel subunit (IC) is only $16 \mathrm{~cm}$ thick in Hole $701 \mathrm{C}$ and is both overlain and underlain by Bruniopsis ooze.

in Core 114-701C-51X where the bit encountered a very hard layer and lost one of its roller cones. While taking this wash core, the XCB shoe was flared, which prevented retrieval of the core barrel and forced termination of the hole.

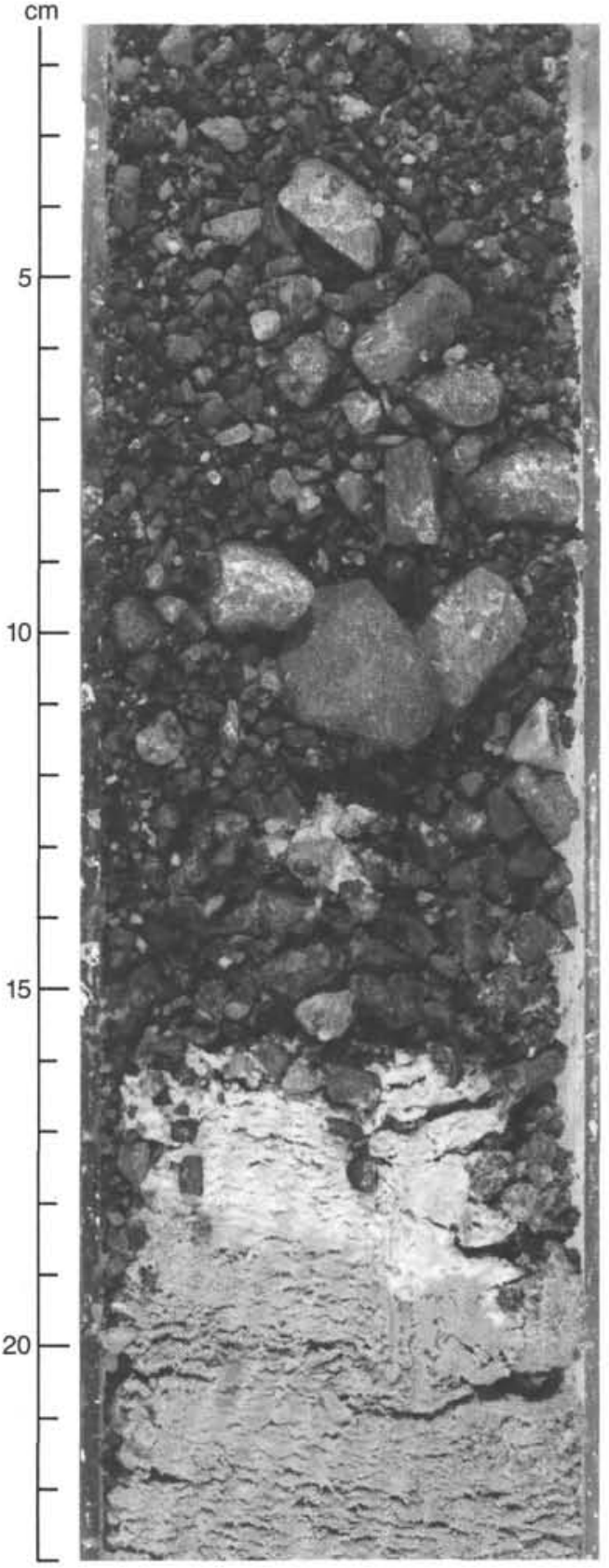

Figure 9. The contact between the sand/gravel subunit (IC) and underlying Bruniopsis ooze (Sample 114-701C-19H-1, 2-23 cm). At Hole 701C, the sand/gravel is embedded within the Bruniopsis ooze.

\section{Paleoenvironment}

Operations at Site 701 recovered a middle Eocene to Quaternary pelagic sequence of dominantly siliceous sediments. The lithofacies and biofacies at this site provide information on the tectonic and oceanographic evolution of the subantarctic South Atlantic Ocean.

\section{Volcanic Ash}

Discrete ash horizons of late Miocene to Quaternary age were recovered in Hole 701B and of early Pliocene to Quaternary age in Holes 701A and 701C (Table 3). The thickness of the ash horizons varies from $<1$ to $10 \mathrm{~cm}(30-40 \mathrm{~cm}$ in Section $114-701 \mathrm{~A}-5 \mathrm{H}-4)$. In addition to these ash layers, disseminated and thin discrete ash horizons of early Oligocene to late Mio- 


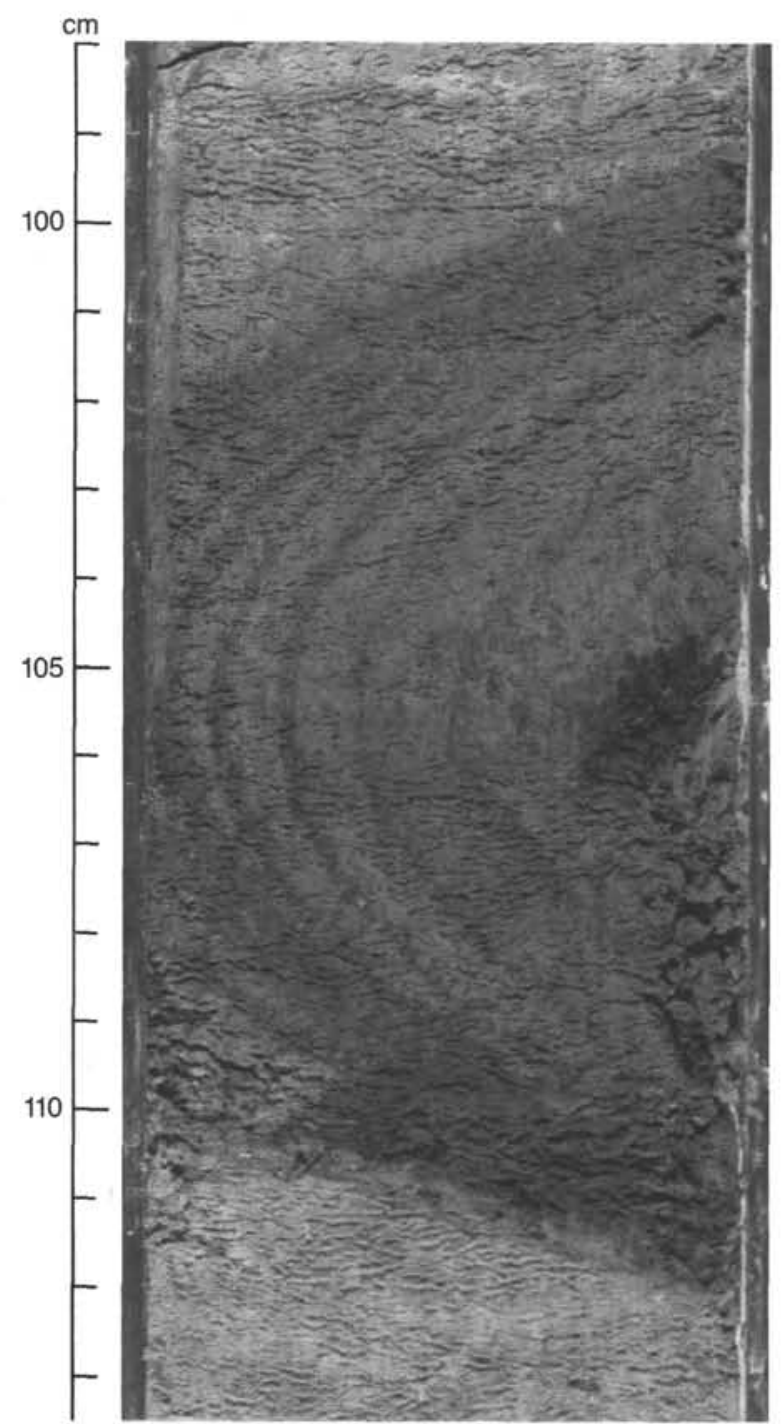

Figure 10. The remains of a manganese nodule that has been reduced and remobilized into the surrounding sediment (Sample 114-701C-23H$3,98-113 \mathrm{~cm})$.

cene age occur irregularly throughout the three holes cored at Site 701 .

The mechanism of transport of ash to Site 701 may have been by direct air fall, ocean currents, or by sea ice. Air-fall emplacement is most likely because of the great thickness of individual ash layers, the size of the glass shards (maximum $=0.3$ $\mathrm{mm}$, mean $=0.1 \mathrm{~mm}$; Sample $114-701 \mathrm{C}-3 \mathrm{H}-4,105 \mathrm{~cm}$ ), and the lack of a biosiliceous component. These observations imply rapid, concentrated sedimentation of ash, which is not readily achieved by current transport. In addition, the freshness of the glass precludes reworking or long transport. Transport by currents is plausible for the finely disseminated ash. Aerial transport was suggested for glass shards recovered to the west of Site 701 on the Falkland Plateau during Deep Sea Drilling Project (DSDP) Leg 36 (Elliot and Emerick, 1976) (Fig. 12).

To account for the omnipresent ash at Site 701, frequent explosive eruptions must have occurred in the vicinity of the site. Because of the distance from Site 701, the chemical composition of the extrusive rocks, and an assumption of dominant westerly winds, the most likely source areas are (1) the South Sandwich Islands in the Scotia Arc to the southwest and (2) the southern Andes and Patagonia, South America.

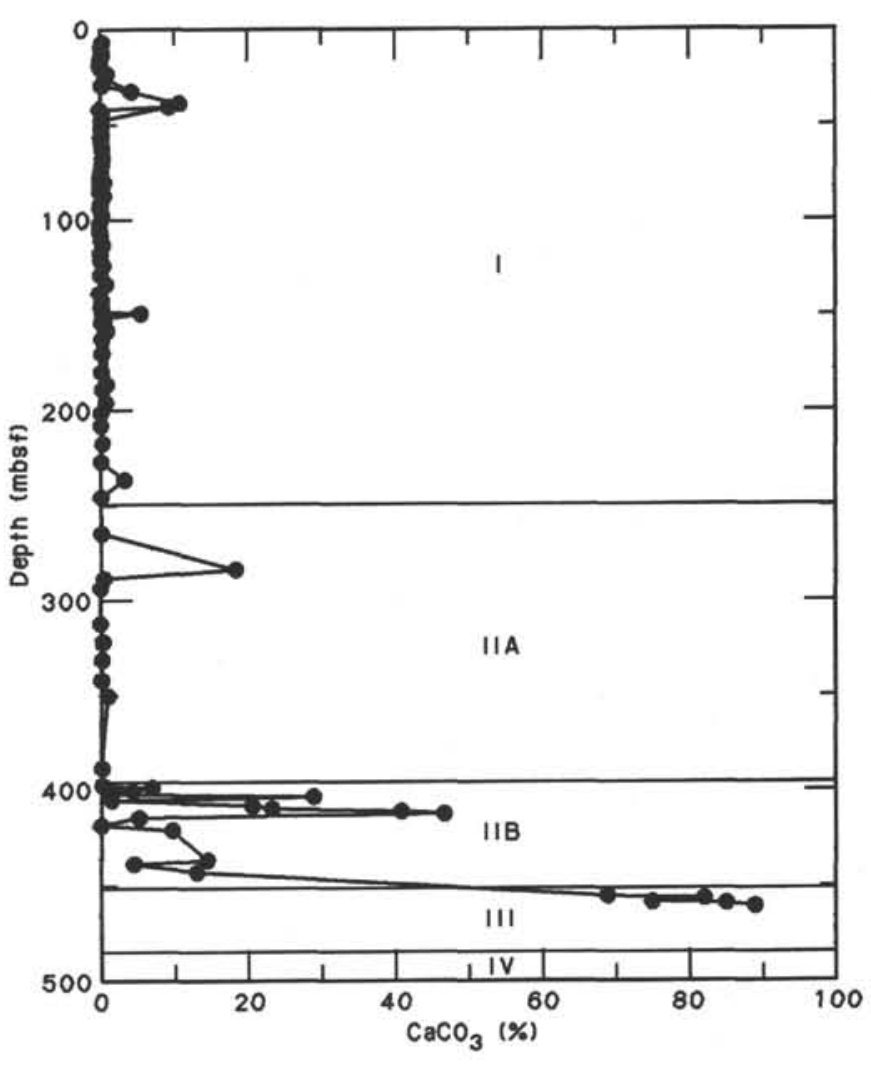

Figure 11. Percent carbonate vs. depth and placement of lithostratigraphic units in Site 701. Note close correspondence between Unit III (indurated chalk) and a high carbonate content of $\sim 80 \%$. Subunit IIB corresponds to the first occurrence of carbonate in the sediment and consists of an admixture of siliceous microfossils, nannofossils, and clay.

The South Sandwich Islands (Scotia Arc in Fig. 12) are the closest volcanic source to Site 701 for the Pliocene and Holocene. $\mathrm{K}-\mathrm{Ar}$ ages of the South Sandwich Islands volcanic rocks are younger than 4 m.y. (Baker, 1968) and no older than 8 m.y., according to seafloor magnetic anomalies (Barker, 1972). The distance between Site 701 and the South Sandwich Islands is presently about $510 \mathrm{~km}$, but was slightly farther before the eastward migration of the site area in response to late Miocene to Recent back-arc spreading. Basalt and subordinate andesite make up about $95 \%$ of the exposed rocks; therefore, explosive activity is not an important mode of construction of the South Sandwich volcanic arc (Baker, 1968). Nevertheless, some ash transport to the Falkland Plateau by west-northwest winds was assumed by Elliot and Emerick (1976). Until the geochemistry of the ash layers can be examined, the South Sandwich Islands will be considered as a potential source for the late Miocene-Quaternary deposition of ash in Hole 701.

Widespread granitic plutons and volcanic fields of Tertiary age are found in the southern Andes and Patagonia as far south as $\sim 51^{\circ} \mathrm{S}$. The distance between this source area and Site 701 is about $3500 \mathrm{~km}$.

Transport of grains of $72 \mu \mathrm{m}$ over a distance of $2000-3000$ $\mathrm{km}$ requires eruptions of great magnitude and winds stronger than those of the North Atlantic at $50^{\circ} \mathrm{N}$ (Shaw et al., 1974). Sufficient winds are present at $50^{\circ} \mathrm{S}$, as shown by the wind velocity profile with velocities that can be up to 1.5 times those of the equivalent latitude in the northern hemisphere (Lamb, 1972). An aerial transport for the $11-$ to $88-\mu \mathrm{m}$ glass shards from South America to the Falkland Plateau ( $2500 \mathrm{~km}$ ) would require a cloud $25 \mathrm{~km}$ high (Elliot and Emerick, 1976). 
Table 3. Distribution of discrete ash horizons at Site 701.

\begin{tabular}{cc}
\hline Age & Interval \\
\hline Quaternary & $114-701 \mathrm{~A}-1 \mathrm{H}-4,52-62 \mathrm{~cm}$ \\
$2 \mathrm{H}-4,14-21 \mathrm{~cm}$ \\
$3 \mathrm{H}-5,122-130 \mathrm{~cm}$ \\
$5 \mathrm{H}-4,30-40 \mathrm{~cm}$ \\
& $3 \mathrm{H}-4,103-109 \mathrm{~cm}$ \\
& $4 \mathrm{H}-2,68-73 \mathrm{~cm}$ \\
& $4 \mathrm{H}-2,135-140 \mathrm{~cm}$ \\
$5 \mathrm{H}-4,70 \mathrm{~cm}$ \\
late Pliocene & $8 \mathrm{H}-4,130 \mathrm{~cm}$ \\
& $114-701 \mathrm{~A}-8 \mathrm{H}-4,54-56 \mathrm{~cm}$ \\
& $114-701 \mathrm{~B}-1 \mathrm{H}-2,85-87 \mathrm{~cm}$ \\
& $114-701 \mathrm{C}-8 \mathrm{H}-5,117-119 \mathrm{~cm}$ \\
$8 \mathrm{H}-6,85-86 \mathrm{~cm}$ \\
$9 \mathrm{H}-1,68-70 \mathrm{~cm}$ \\
early Pliocene & $114-701 \mathrm{~B}-3 \mathrm{H}-4,85-92 \mathrm{~cm}$ \\
$4 \mathrm{H}-1,132 \mathrm{~cm}$ \\
$6 \mathrm{H}-1,132-138 \mathrm{~cm}$ \\
$6 \mathrm{H}-3,25-26 \mathrm{~cm}$ \\
$7 \mathrm{H}-2,124-125 \mathrm{~cm}$ \\
& $10 \mathrm{H}-4,120-124 \mathrm{~cm}$ \\
& $14 \mathrm{H}-3,80 \mathrm{~cm}$ \\
& $114-701 \mathrm{C}-10 \mathrm{H}-4,35 \mathrm{~cm}$ \\
& \\
& $114-701 \mathrm{~B}-8 \mathrm{H}-1,20-25 \mathrm{~cm}$ \\
\hline &
\end{tabular}

In spite of the slightly higher mean size of the glass shards within the discrete ash layers at Site $701(100 \mu \mathrm{m})$, it is plausible that they were transported $3500 \mathrm{~km}$ from Patagonia and the southern Andes, based on the previous example. In addition, the age of the older ash horizons (older than late Miocene) and disseminated ash supports this interpretation. Other than the south Andean and Patagonian extrusive rocks, no regional volcanism is known to have occurred prior to the formation of the Scotia Arc. Alternately, the source may have been one or several volcanoes that have subsequently subsided below sea level and become dormant, although this seems unlikely.
We suggest, therefore, that the southern Andes and Patagonia were a potential source region for a large proportion of the ash found at Site 701. Some Pliocene to Quaternary ash horizons may have had their origin from the nearby South Sandwich Islands (Federmann et al., 1982). The large quantity of ash required to form the thick ash horizons of the upper Miocene and Holocene at Site 701 suggests the ejection of huge particle clouds into the atmosphere. These eruptions may have influenced the climate of the southern hemisphere.

\section{Ichnology}

Bioturbation is diffuse throughout much of Site 701. The ichnofauna is dominated by Planolites, and Zoophycos does not occur above Sample 114-701C-23H, 77-79 cm.

The discrete ash layers in Site 701 do not appear to be bioturbated, perhaps because the ash horizons were inhospitable to burrowing organisms. When burrows occur through thin ash horizons, the volcanic material forms an incomplete ring around the periphery of the burrow, resulting in a false halo. The bioturbant organisms may have actively eliminated volcanic ash from the burrow.

The Bruniopsis mirabilis subunit (IB) is not macroscopically bioturbated. The absence of bioturbant organisms during this interval is probably related to low dissolved oxygen concentrations at the seafloor. The benthic fauna were unable to exploit the relatively high organic carbon content of the Bruniopsis sediment. A typical ichnocommunity occurs in the diatom oozes immediately overlying and underlying the Bruniopsis ooze.

\section{Bruniopsis Ooze (Subunit IB)}

A monospecific assemblage of Bruniopsis ooze (Subunit IB) was recovered in the upper Miocene of Holes 701B and 701C. Diatom biostratigraphy indicates that the upper and lower limits of the Bruniopsis ooze are bounded by hiatuses ( 2.6 and 0.6 m.y. duration, respectively; see "Biostratigraphy" section, this chapter). Visual core descriptions and smear slide analyses suggest the following:

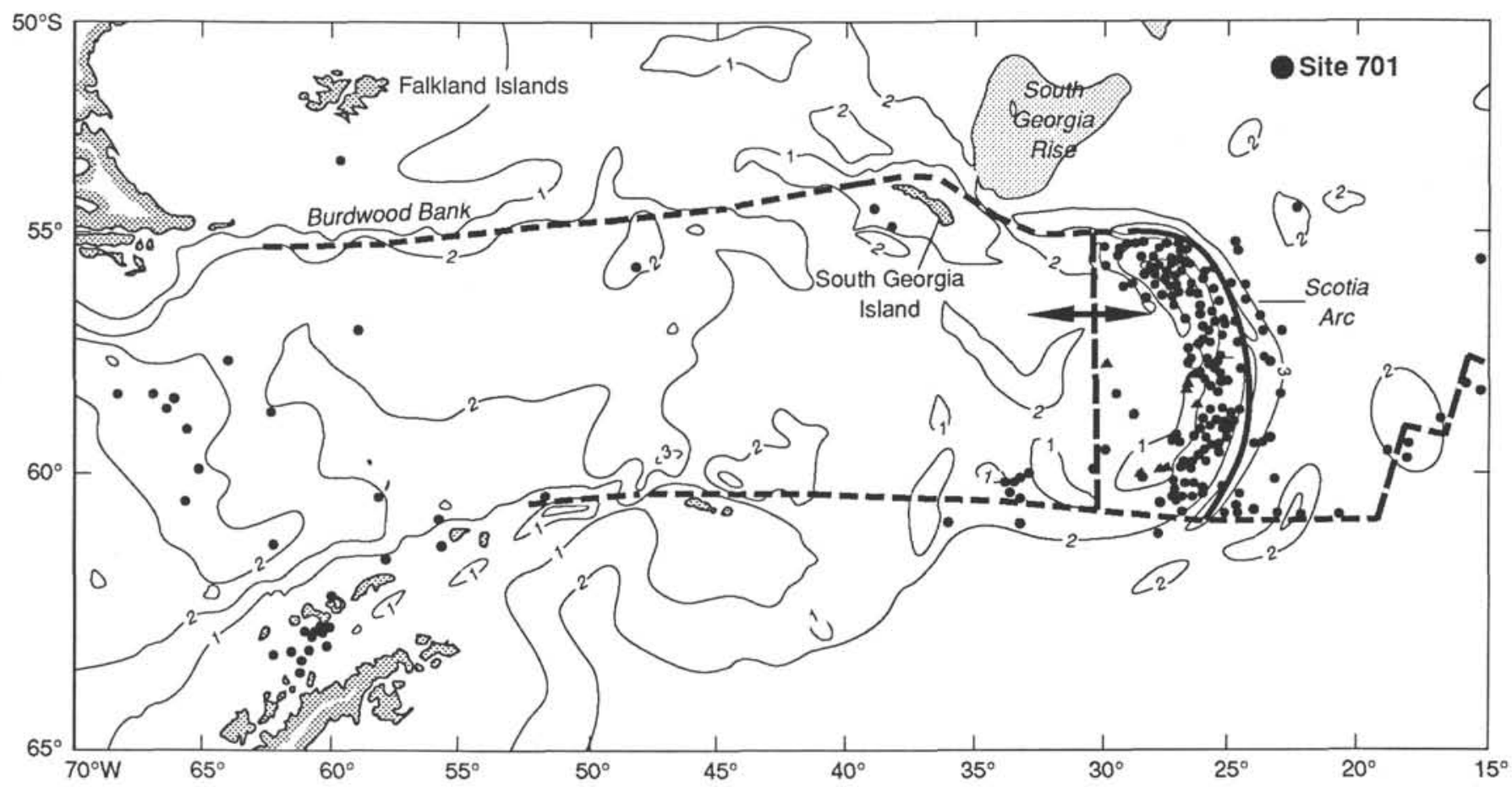

Figure 12. Position of Site 701 relative to the Scotia Arc. The Scotia Arc is inferred to be the source area for the many ash horizons found in the Pliocene-Quaternary sediments of Site 701 . 
1. The siliceous microfossil assemblage is dominated by a warm to subtropical flora composed of Bruniopsis mirabilis and Dictyocha. No calcareous microfossils were preserved in this interval.

2. The Bruniopsis ooze is very finely laminated with many alternations of pale olive (5Y 6/3) and dark gray (N4/) horizons. The scale of the laminations is on the order of millimeters.

3. Subunit IB (Bruniopsis ooze) lacks any evidence of bioturbation, whereas the diatom ooze that overlies and underlies Subunit IB contains a typical ichnofauna.

4. The organic carbon content of the Bruniopsis ooze averages $0.55 \%$, which is several times greater than the average of $0.1 \%-0.2 \%$ in the other lithostratigraphic units of Site 701 .

5. The dark laminae within the Bruniopsis ooze contain iron sulfide (pyrite) coatings on microfossils, particularly radiolarians. The pyrite, however, is not restricted to the dark laminae and occurs within lighter intervals, but in lower abundance.

The combined evidence of fine lamination, absence of bioturbation, high organic carbon content, and the presence of pyrite strongly suggests an oxygen-poor, if not anoxic, environment. Suboxic to anoxic conditions occurred within the sediment pore water, and may have extended to the overlying bottom water as well.

Similar laminated diatomites were described from DSDP Site 520 in the South Atlantic, approximately $26^{\circ}$ north of Site 701 (Hsü et al., 1984). These diatomites also lack bioturbation, contain significant organic carbon and pyrite, and are interpreted to represent an oxygen-depleted, reducing environment. The major difference between Sites 520 and 701 is in diatom assemblages. Site 520 is dominated by Ethmodiscus rex, along with a moderately diverse tropical to subtropical assemblage of late Miocene diatoms, including Bruniopsis mirabilis. The nearly monospecific assemblage of Ethmodiscus rex was explained by differential dissolution of less resistant forms and concentration by winnowing and downslope transport (Gombos, 1984).

The synchronous deposition of laminated diatomites at both Sites 701 and 520 suggests that this event may have been basinwide throughout the South Atlantic. Clearly, the environmental conditions that gave rise to the Bruniopsis ooze in the late Miocene were unusual. The deposition of suboxic-anoxic diatomites has important implications for the chemical nature and production of bottom waters at this time. This event was probably tied to other late Miocene paleoceanographic events (e.g., antarctic glaciation, carbon shift, increased upwelling, sea-level regression, Messinian Salinity Crisis, etc.), but speculation is unwarranted at this time.

\section{Sand/Gravel (Subunit IC)}

Subunit IC consists of moderately sorted sands and gravels composed of lithologies representing many rock types. The precise stratigraphic position of this subunit is uncertain because of discontinuous recovery (Figs. 7 and 9).

At Hole 701B, the sand/gravel subunit is $2.85 \mathrm{~m}$ thick and is overlain by Bruniopsis ooze (Core 114-701B-12X). The core catcher of Core 114-701B-12X contains gravel immediately overlying $\sim 13 \mathrm{~cm}$ of clay-bearing diatom ooze containing a typical subantarctic diatom assemblage. The entire sand/gravel subunit is normally graded, which may reflect gravity sedimentation or may have been artificially induced during coring by settling in a partially filled core liner. The sand/gravel subunit also contains sediment clasts of diatom ooze.

In Hole $701 \mathrm{C}$, the sand/gravel subunit is only $16 \mathrm{~cm}$ thick (Fig. 9). However, core recovery in both Holes 701A and 701B was poor, contributing to the ambiguous stratigraphic relationships.
We consider three alternative explanations for the origin of the sand/gravel subunit:

1. During Leg 114 operations, downhole displacement of surficial lag deposits has been a persistent problem. The recovery of the sand/gravel subunit at a similar stratigraphic horizon in both Holes 701B and 701C argues that the subunit is in place, unless downhole contamination occurred simultaneously at the same stratigraphic level in both holes. In addition, the thickness of the sand/gravel subunit $(2.85 \mathrm{~m})$ is greater than the sum of the gravel-sized lithic fragments encountered above this subunit, and no sand was recovered anywhere in the upper part of the section.

2. The sand/gravel subunit may represent a residual lag deposit of ice-rafted debris. The first occurrence of ice-rafted detritus in the subantarctic South Atlantic (i.e., Falkland Plateau) occurs near the time of deposition of the Bruniopsis ooze in the late Miocene (Ciesielski et al., 1982). In order to accumulate a lag deposit, a sufficient period of erosion or nondeposition is required. A 2.6-m.y. hiatus has been detected below the Bruniopsis ooze, but the stratigraphic relationship between the sand/ gravel subunit and the Bruniopsis ooze is uncertain because of poor core recovery. At Hole 701B, the sand/gravel appears at the base of the Bruniopsis ooze, whereas at Hole 701C, it was found within the Bruniopsis ooze subunit.

3. A third alternative is that the sand/gravel subunit was deposited by a turbidity current. The source area is uncertain, but lithologies within the sand/gravel indicate a continental origin. The origin may be a turbidite from a nearby basement high. One problem with this interpretation is the lack of fine-grained (silt-clay) material typically associated with turbidites. It is possible, however, that the sand/gravel was washed clean of finer material during the drilling process.

We have also considered the possibility that the co-occurrence of the sand/gravel and Bruniopsis ooze may not be coincidental. We find little evidence for the Bruniopsis ooze being deposited under conditions of gravity sedimentation related to a turbidite. However, concentration of monospecific diatom oozes by current winnowing and downslope transport has been suggested previously (Mikkelsen, 1977).

\section{Summary}

At Site 701, middle Eocene oceanic crust (Chron C22) is overlain by indurated nannofossil chalk (Unit III) of middle Eocene age (calcareous nannofossil Zone NP15). The carbonate content is high $(80 \%)$ and is altered and stained by iron manganese oxides, probably resulting from diagenetic alterations with the underlying basalt. The boundary between Unit III (indurated chalk) and Subunit IIB (mixed siliceous/nannofossil/clay sediment) occurs at 452.8 mbsf and is marked by a $6-m . y$. hiatus spanning the upper Eocene-lower Oligocene.

The carbonate component disappears at $\sim 395$ mbsf, coincident with a hiatus spanning the lower to upper Oligocene, and the sediment composition changes to a siliceous mud (Subunit IIA). The elimination of carbonate sedimentation may represent a shoaling of the CCD and/or subsidence of Site 701 below the CCD.

The boundary between Subunits IIA (siliceous clay) and ID (clay-bearing diatom ooze) at $243.8 \mathrm{mbsf}$ is characterized by a change from fine-grained terrigenous sediment (Subunit IIA) to dominantly biogenic siliceous deposition (Subunit ID). This change coincides with two hiatuses at 257 and 249 mbsf that span the upper Oligocene to middle Miocene. These hiatuses were probably related to the opening of the Drake Passage to deep-water flow and the development of a strong ACC. Above the hiatuses at Site 701, sedimentation is dominated by biogenic 
silica, which reflects the northward progression of the antarctic biosiliceous province.

An unusual event occurred during the late Miocene. An allochthonous gravel/sand (Subunit IC) seems to be associated with a monospecific assemblage of diatom ooze (Bruniopsis mirabilis; Subunit IB). Unfortunately, the precise stratigraphic relationship of the units is complicated by poor core recovery. The Bruniopsis ooze is finely laminated, lacks bioturbation, contains high organic carbon and pyrite, and is interpreted to represent deposition under suboxic to anoxic conditions. The Bruniopsis ooze is late Miocene in age (just below Chron C3AN) and is bracketed by hiatuses at both its upper and lower limits (see "Biostratigraphy" section). The overlying Subunit IA consists of bioturbated diatom ooze containing a typical subantarctic assemblage of Pliocene to Quaternary age. Numerous discrete and disseminated ash horizons occur throughout the Pliocene-Quaternary, along with disseminated ash of early Oligocene to late Miocene age, indicating frequent explosive volcanism in the region. Possible sources of the ash are the south Andes and Patagonia region, $3500 \mathrm{~km}$ to the west, and the Scotia Arc, 510 $\mathrm{km}$ to the southwest.

\section{BIOSTRATIGRAPHY}

Site 701 was drilled in a water depth of $4636.7 \mathrm{~m}$. Hole 701A recovered 8 cores, Hole $701 \mathrm{~B}$ recovered 14 cores, and Hole $701 \mathrm{C}$ recovered 51 cores. Core-catcher samples and a number of samples with the sections were examined for microfossils. The planktonic foraminifer Neogloboquadrina pachyderma (with sinistral coiling) is common in Section 114-701A-4H, CC; all other core-catcher samples examined from Holes 701A and $701 \mathrm{~B}$ are devoid of planktonic foraminifers. No in-situ calcareous nannofossils or calcareous benthic foraminifers were preserved in the core-catcher samples from either hole. Siliceous microfossils were recovered continuously throughout both holes. In Hole 701C, calcareous microfossils were preserved in Eocene, lower Oligocene, and Quaternary sediments (Section 114-701C$4 \mathrm{H}, \mathrm{CC})$. Siliceous microfossils are present throughout, except in the lowermost three cores.

Table 4 and Figure 13 show the age assignments based on diatom, radiolarian, silicoflagellate, calcareous nannofossil, planktonic foraminifer, and paleomagnetic data. The zonal assignments of each microfossil group are illustrated in Figures 14 to 16.

\section{Paleoenvironment}

The Paleogene-Neogene sedimentary sequence recovered in the three holes at Site 701 offers the opportunity for comparison with results from Hole 699A.

The greater water depth at Site 701 (930 m deeper than at Site 699) resulted in much stronger dissolution of calcareous microfossils from the upper Eocene to Recent. Although abundant and diverse in the middle Eocene samples, the calcareous nannofossils and planktonic foraminifers show strong dissolution from the upper Eocene on, indicating deposition near the CCD for the short intervals in which they are present and deposition below the CCD for those intervals in between. As a result, the Quaternary to upper Miocene sediments at Site 701 are practically barren of calcareous microfossils, except for a lower Quaternary occurrence of very rare left-coiling Neogloboquadrina pachyderma. However, major changes in abundance and species composition correlate at both sites, despite the major difference in preservation. During the middle Eocene, warm-water species were present at both sites (Discoaster and Acarinina species are found in Holes 699A and 701C). After the middle Eocene, the abundance of calcareous microfossils dropped, warm-water species disappeared, and the diversity of the assemblages decreased. In Hole 701C, only occasional occurrences of calcare- ous faunas and floras are found throughout the upper Eocene and Oligocene, with a final peak in the Miocene. Similarly, the last peak in calcareous microfossil occurrence in Hole 699A is found in the Miocene (Fig. 17). Benthic foraminifers are abundant and well preserved in only one middle Eocene sample. The co-occurrences of buliminids, Lenticulina spp., and Hanzawaia ammophilus, with abundant Alabamina dissonata, and the absence of Osangularia mexicana suggest that the paleodepth at this time was $2500-3000 \mathrm{~m}$.

Siliceous microfossils are present from the lower Oligocene to Recent, although generally with lower abundance and relatively poor preservation in the Paleogene. The Neogene sediment is mainly a diatom ooze. The diatoms show a change in assemblage composition from the lower Oligocene assemblages (which still contain a number of warm-water species) toward the Neogene, with endemic antarctic-subantarctic species becoming prevalent during the Miocene.

A conspicuous feature at this site is the more than $20-\mathrm{m}$ thick, finely laminated Bruniopsis mirabilis ooze in the upper Miocene, just below Chron C3AN (Fig. 18; see "Paleomagnetics" section, this chapter). The gigantic, centric diatom B. mirabilis makes up more than $90 \%$ of the sediment in most of the laminae. In other laminae, it occurs together with other diatom species and/or the silicoflagellate Dictyocha fibula. A relatively high organic carbon content is characteristic of this diatomite. Furthermore, the silicoflagellates suggest warmer surface waters for this interval in the late Miocene at this site. All of the preceding points indicate special paleoceanographic conditions for the deposition of this nearly monospecific diatom ooze. If the first appearance datum (FAD) of Thalassiosira torokina actually lies at ca. 6 m.y., it may represent a time interval as short as only $100,000 \mathrm{yr}$.

\section{Calcareous Nannofossils}

\section{Hole $701 \mathrm{~A}$}

Eight core samples and all the core-catcher samples were examined for Hole 701A. Only one sample contains in-situ nannofossils.

\section{Biostratigraphy}

Samples 114-701A-1H-5, 80-81 cm, to 114-701A-3H-4, 32$33 \mathrm{~cm}$, are barren of calcareous nannofossils. Sample 114-701A$4 \mathrm{H}-4,12-13 \mathrm{~cm}$, contains Gephyrocapsa spp. and Pseudoemiliana lacunosa. The co-occurrence of these taxa indicates the presence of lower Pleistocene to upper Pliocene strata.

Sample 114-701A-5H-3, 82-83 cm, to Section 114-701A-7H, $\mathrm{CC}$, are either barren or yielded long-ranging, probably reworked coccoliths.

\section{Hole $701 C$}

Fifty-two core samples and all the core-catcher samples were examined from Hole 701C. Samples from the upper part of the hole, above Core 114-701C-24X, are barren of in-situ nannofossils. The lower part of the hole contains influxes of nannofossil floras in varying states of preservation. The nannofossil floras are assigned to the Martini (1971) zones as described in the "Explanatory Notes" chapter, this volume.

\section{Biostratigraphy}

Sections $114-701 \mathrm{C}-1 \mathrm{H}, \mathrm{CC}$, to $114-701 \mathrm{C}-24 \mathrm{H}, \mathrm{CC}$, are barren or contain only rare, reworked nannofossils. Monospecific nannofossil floras of Reticulofenestra perplexa are present in Sample 114-701C-25X-3, 94-95 cm, to Section 114-701C-26X, CC. These indicate a late middle Miocene age. Section 114701C-27X, CC, to Sample 114-701C-43X-2, 34-35 cm, contain only reworked nannofossils. The richest of these reworked as- 
Table 4. Microfossil datums identified at Site 701.

\begin{tabular}{|c|c|c|c|c|c|}
\hline $\begin{array}{c}\text { Microfossil and } \\
\text { paleomagnetic datums }\end{array}$ & Age (Ma) & Reference $^{\mathrm{b}}$ & Interval & $\begin{array}{l}\text { Depth } \\
\text { range }^{c} \\
\text { (mbsf) }\end{array}$ & $\begin{array}{c}\text { Mean } \\
\text { position } \\
\text { (mbsf) }\end{array}$ \\
\hline \multicolumn{6}{|l|}{ Hole 701A: } \\
\hline 1. LAD Hemidiscus karstenii (D) & +0.195 & 19 & $1 \mathrm{H}-4,58 \mathrm{~cm}$, to $1 \mathrm{H}-4,116 \mathrm{~cm}$ & $5.08-5.66$ & (5.37) \\
\hline 2. LAD Actinocyclus ingens (D) & +0.62 & 10 & $2 \mathrm{H}, \mathrm{CC}$, to $3 \mathrm{H}-1,75 \mathrm{~cm}$ & $17.80-18.55$ & (18.18) \\
\hline 3. LAD Stylatractus universus (R) & +0.40 & 11 & $2 \mathrm{H}, \mathrm{CC}$, to $3 \mathrm{H}, \mathrm{CC}$ & $17.80-27.30$ & $(22.55)$ \\
\hline 4. LAD Saturnalis circularis (R) & +0.70 & 11 & $3 \mathrm{H}, \mathrm{CC}$, to $4 \mathrm{H}, \mathrm{CC}$ & $27.30-36.80$ & $(32.05)$ \\
\hline 5. LAD Rhizosolenia barboi (D) & +1.50 & 10 & $4 \mathrm{H}, \mathrm{CC}$, to $5 \mathrm{H}-2,140 \mathrm{~cm}$ & $36.80-39.70$ & $(38.25)$ \\
\hline 6. LAD Coscinodiscus kolbei (D) & +1.89 & 10 & $5 \mathrm{H}-5,114 \mathrm{~cm}$, to $6 \mathrm{H}-4,104 \mathrm{~cm}$ & $43.94-51.84$ & (47.89) \\
\hline 7. LAD Coscinodiscus vulnificus (D) & +2.20 & 10 & $6 \mathrm{H}, \mathrm{CC}$, to $7 \mathrm{H}-3,77 \mathrm{~cm}$ & $55.80-59.57$ & $(57.69)$ \\
\hline 8. LAD Helotholus vema (R) & +2.43 & 11 & $6 \mathrm{H}, \mathrm{CC}$, to $7 \mathrm{H}, \mathrm{CC}$ & $55.80-65.30$ & (60.55) \\
\hline 9. LAD Desmospyris spongiosa $(\mathrm{R})$ & +2.43 & 11 & $6 \mathrm{H}, \mathrm{CC}$, to $7 \mathrm{H}, \mathrm{CC}$ & $55.80-65.30$ & $(60.55)$ \\
\hline Hiatus-duration $\sim 0.5$ m.y. $(\sim 3.0-2.5 \mathrm{Ma})$ & & & & $70.26-65.49$ & \\
\hline *10. LAD Nitzschia interfrigidaria (D) & +2.81 & 10 & $8 \mathrm{H}-1,19 \mathrm{~cm}$, to $8 \mathrm{H}-3,60 \mathrm{~cm}$ & $65.49-68.90$ & $(67.20)$ \\
\hline *11. LAD Cosmiodiscus insignis (D) & +2.49 & 10 & $8 \mathrm{H}-1,19 \mathrm{~cm}$, to $8 \mathrm{H}-3,60 \mathrm{~cm}$ & $65.49-68.90$ & $(67.20)$ \\
\hline *12. LAD Nitzschia weaveri (D) & +2.64 & 10 & $8 \mathrm{H}-3,60 \mathrm{~cm}$, to $8 \mathrm{H}-4,46 \mathrm{~cm}$ & $68.90-70.26$ & (69.58) \\
\hline 13. F concurrent $C$. vulnificus and $C$. insignis (D) & +3.10 & 10 & $>8 \mathrm{H}, \mathrm{CC}$ & \multicolumn{2}{|c|}{$>74.80$ (base of hole) } \\
\hline
\end{tabular}

Hole 701B:

\author{
1. FAD N. weaveri (D) \\ 2. FAD N. interfrigidaria (D) \\ 3. Top Nunivak subchron \\ 4. Base Nunivak subchron \\ 5. FAD? Nitzschia angulata (D) \\ 6. Top Sidjufall subchron \\ 7. Base Sidjufall subchron \\ 8. LAD Triceraspyris coronata (R) \\ 9. LAD Thalassiosira torokina (D) \\ 10. Top Thvera subchron \\ 11. Base Thvera subchron \\ 12. LAD? Denticulopsis hustedtii (D) \\ 13. LAD Amphymenium challengerae $(\mathrm{R})$ \\ 14. Top C3AN2 \\ 15. Base C3AN2 \\ 16. LAD Bruniopsis (D) dissolutional? \\ 17. LAD Cosmiodiscus insignis v. triangula (D) \\ *18. LAD Lamprocyclas aegles group (R) \\ *19. FAD C. insignis v. triangula (D)
}

Hiatus- $\sim$ duration $=2.3$ m.y. $(8.7-6.4 \mathrm{Ma})$

20. LAD Denticulopsis lauta (D)

Hole 701C:

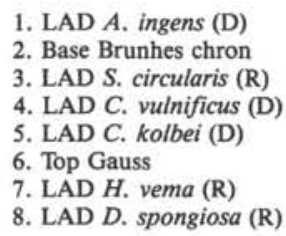

1. LAD A. ingens (D)

2. Base Brunhes chron

3. LAD S. circularis (R)

4. LAD C. vulnificus (D)

5. LAD C. kolbei (D)

6. Top Gauss

7. LAD $H$. vema $(\mathrm{R})$

8. LAD D. spongiosa (R)

Hiatus $-\sim 0.5$ m.y. duration $(\sim 2.5-3.0 \mathrm{Ma})$

*9. LAD $N$. weaveri (D)

*10. LAD N. interfrigidaria (D)

11. F. concurrent C. vulnificus and C. insignis (D)

12. LAD? D. hustedtii (D)

13. FAD $N$. weaveri (D)

14. FAD N. angulata (D)

15. LAD T. coronata (R)

16. LAD T. torokina (D)

17. Top chron C3AN2

18. FAD Nitzschia reinholdii (D)

19. Base chron C3AN2

20. LAD C. insignis v. triangula (D)

21. LAD Bruniopsis (D)

22. FAD C. insignis v. triangula (D)

*23. FAD T. torokina (D)

Hiatus $\sim 2.3$ m.y. duration $(8.7-6.4 \mathrm{Ma})$

*24. LAD D. lauta (D)

25. LAD Denticulopsis dimorpha (D)
$+3.88$

$+4.02$

4.02

4.24

$+4.22$

4.40

4.47

$+4.25$

$+4.77$

4.57

4.77

$+4.48$

$+4.35$

5.68

5.89
+5.53

$+5.53$

$+5.50$

$+6.40$

$\# 8.70$

10

$12 \mathrm{X}, \mathrm{CC}$, to $13 \mathrm{X}, \mathrm{CC}$

$+0.62$

0.73
+0.70

$+2.20$

$+1.89$

2.47

$+2.43$

$+2.43$

$+3.10$

$+4.48$

$+3.88$

$+4.22$

$+4.25$

$+4.77$

5.68

$+6.50$

5.89
5.53

5.53

5.60
+6.40

$+6.4-5.9$

$\# 8.70$

8.6-8.7

$4 \mathrm{H}, \mathrm{CC}$, to $5 \mathrm{H}, \mathrm{CC}$

$4 \mathrm{H}, \mathrm{CC}$, to $5 \mathrm{H}, \mathrm{CC}$

$7 \mathrm{H}, \mathrm{CC}$, to $8 \mathrm{H}, \mathrm{CC}$

$8 \mathrm{H}, \mathrm{CC}$, to $9 \mathrm{H}-2,4 \mathrm{~cm}$

$8 \mathrm{H}, \mathrm{CC}$, to $9 \mathrm{H}-2,4 \mathrm{~cm}$

$11 \mathrm{X}, \mathrm{CC}$, to $12 \mathrm{X}, \mathrm{CC}$

$3 \mathrm{H}, \mathrm{CC}$, to $4 \mathrm{H}, \mathrm{CC}$

$7 \mathrm{H}, \mathrm{CC}$, to $8 \mathrm{H}, \mathrm{CC}$

$7 \mathrm{H}, \mathrm{CC}$, to $8 \mathrm{H}, \mathrm{CC}$ $9 \mathrm{H}, \mathrm{CC}$, to $10 \mathrm{H}, \mathrm{CC}$

$11 \mathrm{H}, \mathrm{CC}$, to $12 \mathrm{H}, \mathrm{CC}$

$12 \mathrm{H}, \mathrm{CC}$, to $13 \mathrm{H}, \mathrm{CC}$

$18 \mathrm{H}, \mathrm{CC}$, to $19 \mathrm{H}, \mathrm{CC}$
$2 \mathrm{H}-1,55 \mathrm{~cm}$, to $2 \mathrm{H}, \mathrm{CC}$

$2 \mathrm{H}-2, \mathrm{CC}$, to $3 \mathrm{H}-2,88 \mathrm{~cm}$

$3 \mathrm{H}-6,43 \mathrm{~cm}$, to $4 \mathrm{H}-3,29 \mathrm{~cm}$

$4 \mathrm{H}-3,104 \mathrm{~cm}, 4 \mathrm{H}-4,39 \mathrm{~cm}$

$4 \mathrm{H}-4,132 \mathrm{~cm}$, to $4 \mathrm{H}-5,119 \mathrm{~cm}$

$4 \mathrm{H}-6,43 \mathrm{~cm}$, to $4 \mathrm{H}-6,122 \mathrm{~cm}$

$5 \mathrm{H}-2,29 \mathrm{~cm}$, to $5 \mathrm{H}-3,39 \mathrm{~cm}$

$5 \mathrm{H}-4,108 \mathrm{~cm}$ to $5 \mathrm{H}-5,39 \mathrm{~cm}$

$5 \mathrm{H}-6,108 \mathrm{~cm}$, to $6 \mathrm{H}-3,8 \mathrm{~cm}$

$5 \mathrm{H}, \mathrm{CC}$, to $6 \mathrm{H}-2,89 \mathrm{~cm}$

$8 \mathrm{H}-3,72 \mathrm{~cm}$, to $8 \mathrm{H}-3,122 \mathrm{~cm}$

$8 \mathrm{H}-4,111 \mathrm{~cm}$, to $8 \mathrm{H}-5,44 \mathrm{~cm}$

$12 \mathrm{X}, \mathrm{CC}$, to $13 \mathrm{X}-1,92 \mathrm{~cm}$

$3 \mathrm{H}-5,110 \mathrm{~cm}$, to $3 \mathrm{H}-6,83 \mathrm{~cm}$

$5 \mathrm{H}-1,80 \mathrm{~cm}$, to $5 \mathrm{H}, \mathrm{CC}$

$6 \mathrm{H}, \mathrm{CC}$, to $7 \mathrm{H}-2,127 \mathrm{~cm}$

$8 \mathrm{H}-2,78 \mathrm{~cm}$, to $8 \mathrm{H}-5,70 \mathrm{~cm}$

$8 \mathrm{H}-3,100 \mathrm{~cm}$, to $8 \mathrm{H}-6,120 \mathrm{~cm}$ $8 \mathrm{H}-3,100 \mathrm{~cm}$, to $8 \mathrm{H}-6,120 \mathrm{~cm}$ $9 \mathrm{H}-1,120 \mathrm{~cm}$, to $9 \mathrm{H}-4,100 \mathrm{~cm}$

$10 \mathrm{H}, \mathrm{CC}$, to $11 \mathrm{H}-3,100 \mathrm{~cm}$

$14 \mathrm{H}-5,38 \mathrm{~cm}$, to $14 \mathrm{H}, \mathrm{CC}$

$16 \mathrm{H}-1,22 \mathrm{~cm}$, to $16 \mathrm{H}-2,21 \mathrm{~cm}$

$16 \mathrm{H}-1,100 \mathrm{~cm}$, to $16 \mathrm{H}-5,14 \mathrm{~cm}$

$16 \mathrm{H}-3,121 \mathrm{~cm}$, to $16 \mathrm{H}-4,108 \mathrm{~cm}$

$16 \mathrm{H}-4,130 \mathrm{~cm}$, to $16 \mathrm{H}-5,14 \mathrm{~cm}$

$16 \mathrm{H}-4,130 \mathrm{~cm}$, to $16 \mathrm{H}-5,14 \mathrm{~cm}$

$19 \mathrm{H}, \mathrm{CC}$, to $20 \mathrm{H}-1,100 \mathrm{~cm}$

80.05-89.50

$89.50-91.38$

96.93-101.79

102.54-103.39

104.32-105.69

106.43-107.22

$109.79-111.39$

$108.00-117.50$

108.00-117.50

$113.58-114.39$

$116.58-120.58$

$117.50-119.89$

$136.50-146.00$

$140.22-140.72$

$142.11-142.94$

$146.00-147.54$

$146.00-147.54$

$174.50-184.99$

$184.92-184.00$

184.00-193.50

184.00-193.50

(188.75)

$15.80-16.35$

22.90-24.13

25.30-34.80

$35.60-44.30$

53.80-56.57

65.58-70.00

63.30-72.80

$63.30-72.80$

67.30-72.00

67.30-72.00

67.30-72.00

$74.00-78.30$

$82.30-91.80$

91.80-95.80

101.30-110.80

$110.80-120.30$

126.68-129.80

139.52-141.01

$140.30-145.44$

143.51-144.88

$145.10-145.44$

$145.10-145.44$

167.80-177.30

$177.30-178.30$

(16.08)

(23.52)

(30.05)

(39.95)

(55.19)

(67.79)

(68.05)

(68.05)

$177.30-178.30$

177.30-178.30

$179.78-186.80$
(69.35)

(69.35)

(76.15)

(87.05)

(93.80)

(106.05)

(115.55)

(128.24)

$(140.27)$

(142.87)

(144.20)

(145.27)

(145.27)

(172.55)

(177.80)

(177.80)

(183.29) 
Table 4 (continued).

\begin{tabular}{|c|c|c|c|c|c|}
\hline $\begin{array}{c}\text { Microfossil and } \\
\text { paleomagnetic datums }\end{array}$ & Age (Ma) & Reference $^{\mathrm{b}}$ & Interval & $\begin{array}{l}\text { Depth } \\
\text { range }^{\mathrm{c}} \\
\text { (mbsf) }\end{array}$ & $\begin{array}{c}\text { Mean } \\
\text { position } \\
\text { (mbsf) }\end{array}$ \\
\hline \multicolumn{6}{|l|}{ Hole $701 \mathrm{C}$ (Cont.): } \\
\hline 26. LAD Nitzschia denticuloides (D) & $8.7-9.1$ & 10 & $22 \mathrm{H}, \mathrm{CC}$, to $23 \mathrm{H}-3,100 \mathrm{~cm}$ & $205.80-209.80$ & (207.80) \\
\hline 27. LAD Cyrtocapsella tetrapera (R) & +11.40 & 22 & $25 \mathrm{X}, \mathrm{CC}$, to $26 \mathrm{X}, \mathrm{CC}$ & $234.30-243.80$ & (239.05) \\
\hline \multicolumn{4}{|c|}{ Possible hiatus-maximum duration $=3.0$ m.y. $(\sim 14.4-11.3 \mathrm{Ma})$} & \multicolumn{2}{|l|}{$243.80-246.30$} \\
\hline *28. FAD N. denticuloides (D) & $\sim 14.40$ & 18 & $27 \mathrm{X}-2,100 \mathrm{~cm}$, to $27 \mathrm{X}, \mathrm{CC}$ & $246.30-253.30$ & $(249.80)$ \\
\hline \multicolumn{2}{|c|}{$\begin{aligned} \text { Hiatus-maximum duration } & =7.6 \mathrm{~m} . \mathrm{y} \cdot(\sim 19.0-11.4 \mathrm{Ma}) \\
\text { minimum duration } & =4.6 \mathrm{~m} . \mathrm{y} \cdot(\sim 19.0-14.4 \mathrm{Ma})\end{aligned}$} & \multicolumn{3}{|c|}{ base of Subunit IIA, 243.80} & \\
\hline 29. LAD Nitzschia maleinterpretaria (D) & 15.60 & 20 & $27 \mathrm{X}-2,100 \mathrm{~cm}$, to $27 \mathrm{X}, \mathrm{CC}$ & $246.30-253.30$ & $(249.80)$ \\
\hline 30. LAD Coscinodiscus rhombicus (D) & 18.40 & & $27 \mathrm{X}-2,100 \mathrm{~cm}$, to $27 \mathrm{X}, \mathrm{CC}$ & $246.30-253.30$ & $(249.80)$ \\
\hline 31. FAD N. maleinterpretaria (D) & 18.80 & 21 & $27 \mathrm{X}, \mathrm{CC}$, to $28, \mathrm{CC}$ & $253.30-262.80$ & (258.05) \\
\hline 32. LAD Rocella gelida (D) & $\sim 21.50$ & 16 & $27 \mathrm{X}, \mathrm{CC}$, to $28 \mathrm{X}, \mathrm{CC}$ & $253.30-262.80$ & (258.05) \\
\hline 33. LAD Synedra jouseana (D) & $\sim 23.70$ & 16 & $27 \mathrm{X}, \mathrm{CC}$, to $28 \mathrm{X}, \mathrm{CC}$ & $253.30-262.80$ & (258.05) \\
\hline 34. LAD $R$. gelida v, schraderi (D) & 22.30 & & $28 \mathrm{X}, \mathrm{CC}$, to $29 \mathrm{X}, \mathrm{CC}$ & $262.80-272.30$ & (267.55) \\
\hline 35. FAD Raphidodiscus marylandicus (D) & $22.7-21.7$ & 23 & $31 \mathrm{X}-1,100 \mathrm{~cm}$, to $31 \mathrm{X}, \mathrm{CC}$ & $282.80-291.30$ & $(287.05)$ \\
\hline 36. LAD Bogorovia veniamini (D) & +19.90 & 13 & $34 \mathrm{X}, \mathrm{CC}$, to $35 \mathrm{X}, \mathrm{CC}$ & $319.80-329.30$ & (324.55) \\
\hline *37. FAD $R$. gelida v. schraderi (D) & $\# 23.4$ & 24 & $41 \mathrm{X}, \mathrm{CC}$, to $42 \mathrm{X}-2,10 \mathrm{~cm}$ & $386.30-387.90$ & (387.10) \\
\hline *38. FAD R. gelida (D) & $\begin{array}{r}23.8-24.0 \\
\sim 26.0\end{array}$ & $\begin{array}{c}25 \\
16,17\end{array}$ & $41 \mathrm{X}, \mathrm{CC}$, to $42 \mathrm{X}-2,10 \mathrm{~cm}$ & $386.30-387.90$ & $(387.10)$ \\
\hline \multirow[t]{2}{*}{ *39. FAD B. veniamini (D) } & 26.5 & 20 & $41 \mathrm{X}, \mathrm{CC}$, to $42 \mathrm{X}-2,10 \mathrm{~cm}$ & $386.30-387.90$ & $(387.10)$ \\
\hline & $26.4-27.3$ & 25 & & & \\
\hline 40. Base Naviculopsis biapiculata (S) & $\sim 23.7$ & 27 & $41 X, C C$, to $43 X, C C$ & $386.30-405.30$ & $(395.80)$ \\
\hline \multicolumn{2}{|c|}{$\begin{aligned} \text { Hiatus-maximum duration } & =11.6 \mathrm{~m} . \mathrm{y} \cdot(23.4-35.0 \mathrm{Ma}) \\
\text { minimum duration } & =8.6 \mathrm{~m} . \mathrm{y} \cdot(23.4-32.0 \mathrm{Ma})\end{aligned}$} & \multicolumn{2}{|c|}{ base of Subunit IIA, 395.15} & & \\
\hline *41. LAAD Pyxilla prolungata (D) & $\sim 30.0$ & 26 & $42 \mathrm{X}-2,10 \mathrm{~cm}$, to $42 \mathrm{X}, \mathrm{CC}$ & $387.90-395.80$ & $(391.85)$ \\
\hline *42. Top Naviculopsis trispinosa Zone (S) & -32.0 & 27 & $41 \mathrm{X}, \mathrm{CC}$, to $43 \mathrm{X}, \mathrm{CC}$ & $386.30-405.30$ & $(395.80)$ \\
\hline 43. > Top of NP21 Zone $(\mathrm{N})$ & $>35.1$ & 4 & $43 \mathrm{X}-4,34 \mathrm{~cm}$ & 400.64 & \\
\hline 44. FAD Cestodiscus antarcticus (D) & e. Oligocene & 17 & $43 \mathrm{X}, \mathrm{CC}$, to $44 \mathrm{X}, \mathrm{CC}$ & $405.30-414.80$ & (410.05) \\
\hline 45. Base $N$. trispinosa Zone (S) & $\sim 35.0$ & 27 & $45 \mathrm{X}, \mathrm{CC}$, to $44 \mathrm{X}, \mathrm{CC}$ & $414.80-424.30$ & (419.55) \\
\hline 46. Base NP19/20 Zone (N) & 37.8 & 4 & $47 \mathrm{X}-2,31 \mathrm{~cm}$, to $47 \mathrm{X}, \mathrm{CC}$ & $435.61-443.30$ & (439.46) \\
\hline *47. Base NP18 Zone (N) & 39.9 & 4 & $48 \mathrm{X}, \mathrm{CC}$, to $49 \mathrm{X}-1,28 \mathrm{~cm}$ & $452.80-453.08$ & $(452.94)$ \\
\hline \multicolumn{2}{|c|}{$\begin{aligned} \text { Hiatus }- \text { maximum duration } & =\sim 7.0 \text { m.y. }(\sim 46.0-39.0 \mathrm{Ma}) \\
\text { minimum duration } & =\sim 2.4 \text { m.y. }(\sim 42.3-39.9 \mathrm{Ma})\end{aligned}$} & \multicolumn{2}{|c|}{ base of Subunit IIB, 452.80} & & \\
\hline 48. NP16/15 Zones (N) & $42.3-49.8$ & 4 & $49 \mathrm{X}-1,27 \mathrm{~cm}$, to $49 \mathrm{X}-3,31 \mathrm{~cm}$ & $453.07-450.11$ & (451.59) \\
\hline 49. P11-10 Zones (F) & $46.0-52.0$ & 7 & $49 \mathrm{X}-1,135 \mathrm{~cm}$, to $49 \mathrm{X}, \mathrm{CC}$ & $454.15-462.30$ & $(458.23)$ \\
\hline 50. NP15/14 Zones (N) & $45.4-52.6$ & 4 & $50 \mathrm{X}-1,75-76 \mathrm{~cm}$ & 463.05 & \\
\hline \multicolumn{6}{|c|}{$\begin{array}{l}\text { a } \mathrm{D}=\text { diatom; } \mathrm{F}=\text { planktonic foraminifer; } \mathrm{N}=\text { calcareous nannofossil; } \mathrm{R}=\text { radiolarian; } \mathrm{S}=\text { silicoflagellate; }+=\text { direct correlation to paleomagnetic stratigra- } \\
\text { phy; \# = absolute age date; * = probable truncation of datum by hiatus. } \\
\text { b. Wise (1983); 2. Martini and Müller (1986); 3. Perch-Nielsen (1985); } 4 \text {. Berggren et al. (1985); 5. Kent and Gradstein (1985); 6. Jenkins (1985); 7. McGowran } \\
\text { (1986); 8. paleomagnetic correlation at Hole 702B; 9. Burckle et al. (1978); 10. Ciesielski (1983); 11. Chen (1975); 12. Weaver (1983); 13. L. H. Burckle (pers. } \\
\text { comm. 1980) to Barron (1985); 14. Barron et al. (1985a), Ciesielski (1985); 15. Ciesielski (1985); 16. Gombos (1984); 17. Fenner (1984); 18. Weaver and Gombos } \\
\text { (1981); 19. Hays and Shackleton (1976); 20. Barron (1985); 21. Barron et al. (1985a); 22. Johnson and Wick (1982); 23. Barron (1983); 24. radiometric age by } \\
\text { Hausback (1984) in Kim and Barron (1986); 25. Barron et al. (1985b); 26. inferred from Gombos and Ciesielski (1983); 27. inferred from Shaw and Ciesielski } \\
\text { (1983). }\end{array}$} \\
\hline
\end{tabular}

semblages occurs in Sample 114-701C-38X-2, 34-35 cm, to Section 114-701C-38X, CC, and contains rare specimens of Reticulofenestra umbilica, Reticulofenestra davisei, Reticulofenestra bisecta, Chiasmolithus altus, and Cyclicargolithus floridanus.

Strongly etched in-situ nannofossil floras occur sporadically in the interval between Samples 114-701C-43X-4, 34-35 cm, and 114-701C-47X-2, 30-31 cm. These nannofossil floras include Isthmolithus recurvus, $R$. bisecta, $R$. umbilica, $C$. altus, Clausicoccus subdictichus (only in Sample 114-701C-44X-2, 130$131 \mathrm{~cm})$, C. floridanus, Blackites spinosis, and Chiasmolithus sp. This interval is assigned to NP21-19 (lower Oligocene-upper Eocene) on the basis of the co-occurrence of $C$. subdistichus and $I$. recurvus. The FAD of the latter species defines the base of NP19.

Below this interval, $I$. recurvus is absent from the sparse nannofossil floras, and Chiasmolithus oamaruensis, the FAD of which defines the base of NP18, is present in samples between Sections 114-701C-47X, CC, and 114-701C-48X, CC, thus indicating the presence of NP18 (upper Eocene).
A stratigraphic break probably occurs between Section 114 701C-48X, CC, and Sample 114-701C-49X, 27-28 cm (NP16$15)$, where there is also a change in the preservation of the nannofossil floras from predominantly etched forms to strongly overgrown forms. The occurrence of Nannotetrina fulgens in Samples 114-701C-49X-1, 27-28 cm, and 114-701C-49X-3, 30 $31 \mathrm{~cm}$, indicates the presence of NP16-15 (middle Eocene). Sample $114-701 \mathrm{C}-50 \mathrm{X}-1,75-76 \mathrm{~cm}$, is assigned to NP15-14 (middle lower Eocene), and it has a nannofossil flora similar to that recorded in the overlying interval, but without $N$. fulgens. Section 114-701C-51X, CC, is barren of calcareous nannofossils and is believed to be of igneous origin.

\section{Paleoenvironment}

Deposition below the CCD and the cold surface waters have caused much of the sedimentary sequence penetrated in Hole $701 \mathrm{C}$ to be barren of calcareous nannofossils. Occasionally, the CCD was low enough and the surface waters warm enough to allow the deposition of calcareous nannofossils. These inter- 


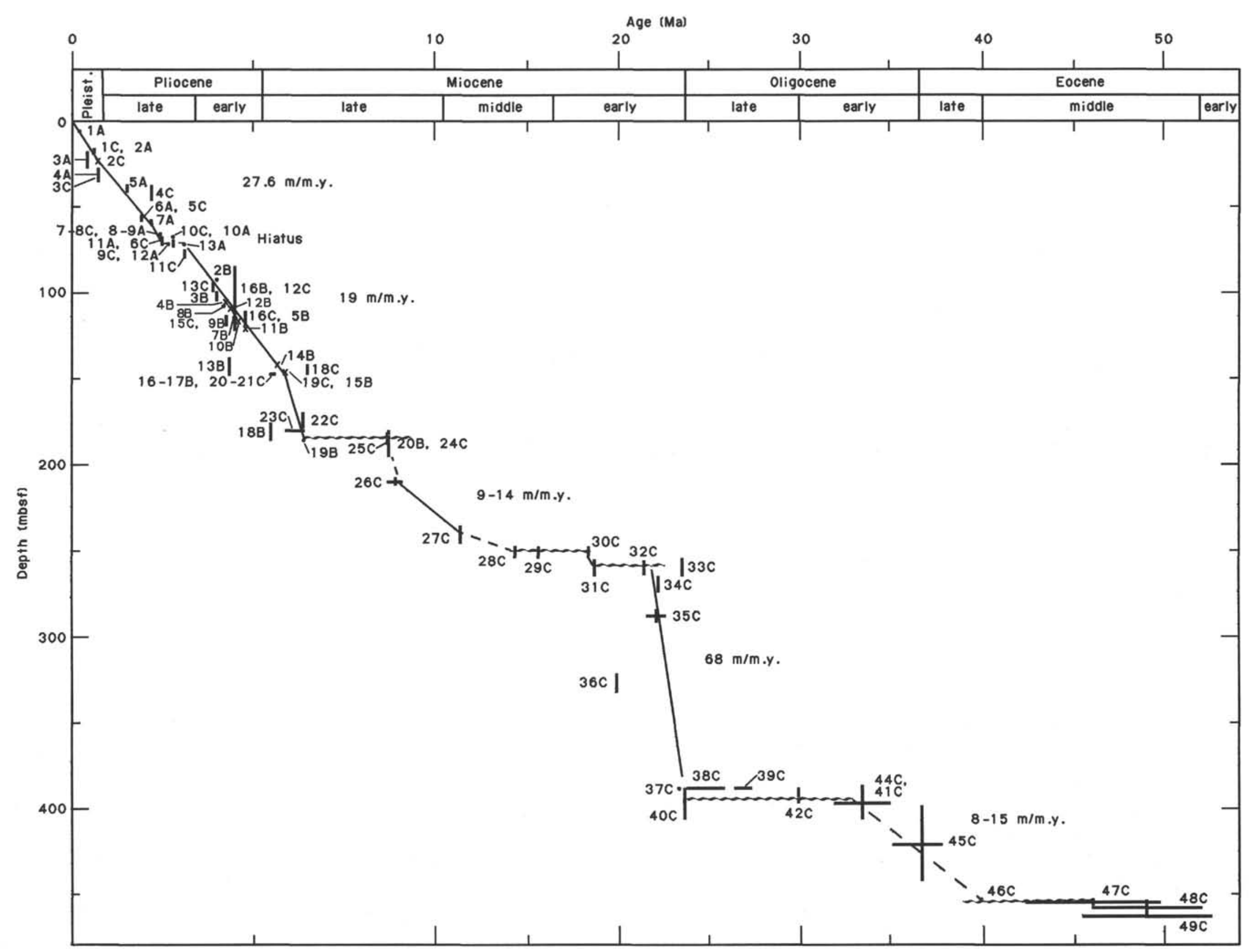




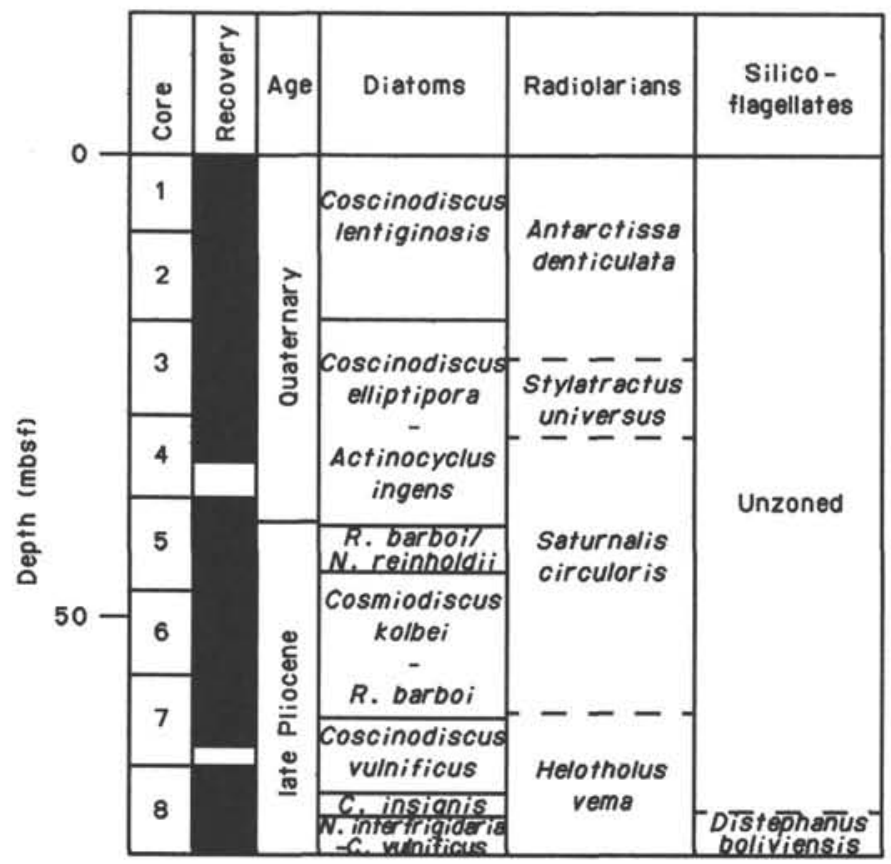

Figure 14. Hole 701A chronostratigraphic summary.

ludes were during the middle Miocene, early Oligocene to late Eocene, and the middle Eocene. The monospecific assemblages of $R$. perplexa in the upper middle Miocene are indicative of cold surface waters.

\section{Preservation}

Nannofossil floras above Sample 114-701C-49X-6, 29-30 cm, are slightly to strongly etched, whereas the underlying samples are overgrown with secondary calcite deposition.

\section{Planktonic Foraminifers}

Samples from the core catchers of Cores 114-701A-1H to 114-701A-8H were examined and yielded only siliceous fossils, except for Section 114-701A-4H, CC, which contains common specimens of Neogloboquadrina pachyderma with a sinistral coiling. Core-catcher samples from Sections 114-701B-1X to 114-701B-10X, 114-701B-12X, and 114-701B-14X, are completely barren of planktonic foraminifers.

Hole $701 \mathrm{C}$ drilled a thick $(\sim 453 \mathrm{~m})$ sequence of siliceous oozes that lies above a thin $(29 \mathrm{~m})$ sequence of nannofossil chalks. Planktonic foraminifers are absent in the siliceous sediments except in Section 114-701C-4H, CC, which contains a few specimens of sinistral $N$. pachyderma. Only samples from the underlying carbonate sequence contain planktonic foraminifers. Except for Section 114-701C-4H, CC, Sections 114-701C-1H, $\mathrm{CC}$, to $114-701 \mathrm{C}-47 \mathrm{X}, \mathrm{CC}$, are barren.

In Section 114-701C-48X, CC, rare unidentified globigerinids with strongly dissolved tests are present. In Samples 114$701 \mathrm{C}-49 \mathrm{X}-1,135-137 \mathrm{~cm}$, to $114-701 \mathrm{C}-49 \mathrm{X}-2,135-137 \mathrm{~cm}$, there are rare planktonic foraminifers represented only by Acarinina primitiva. In the interval between Sections 114-701C-49X-3 and 114-701C-49X, CC, abundant planktonic foraminifers indicate an early middle Eocene age, from the lower part of Zones P11P10.

Only the lowermost core samples contain abundant planktonic foraminifers, which exhibit moderate preservation and thus were deposited above the planktonic foraminifer lysocline. The assemblage is indicative of an early middle Eocene age, ac-

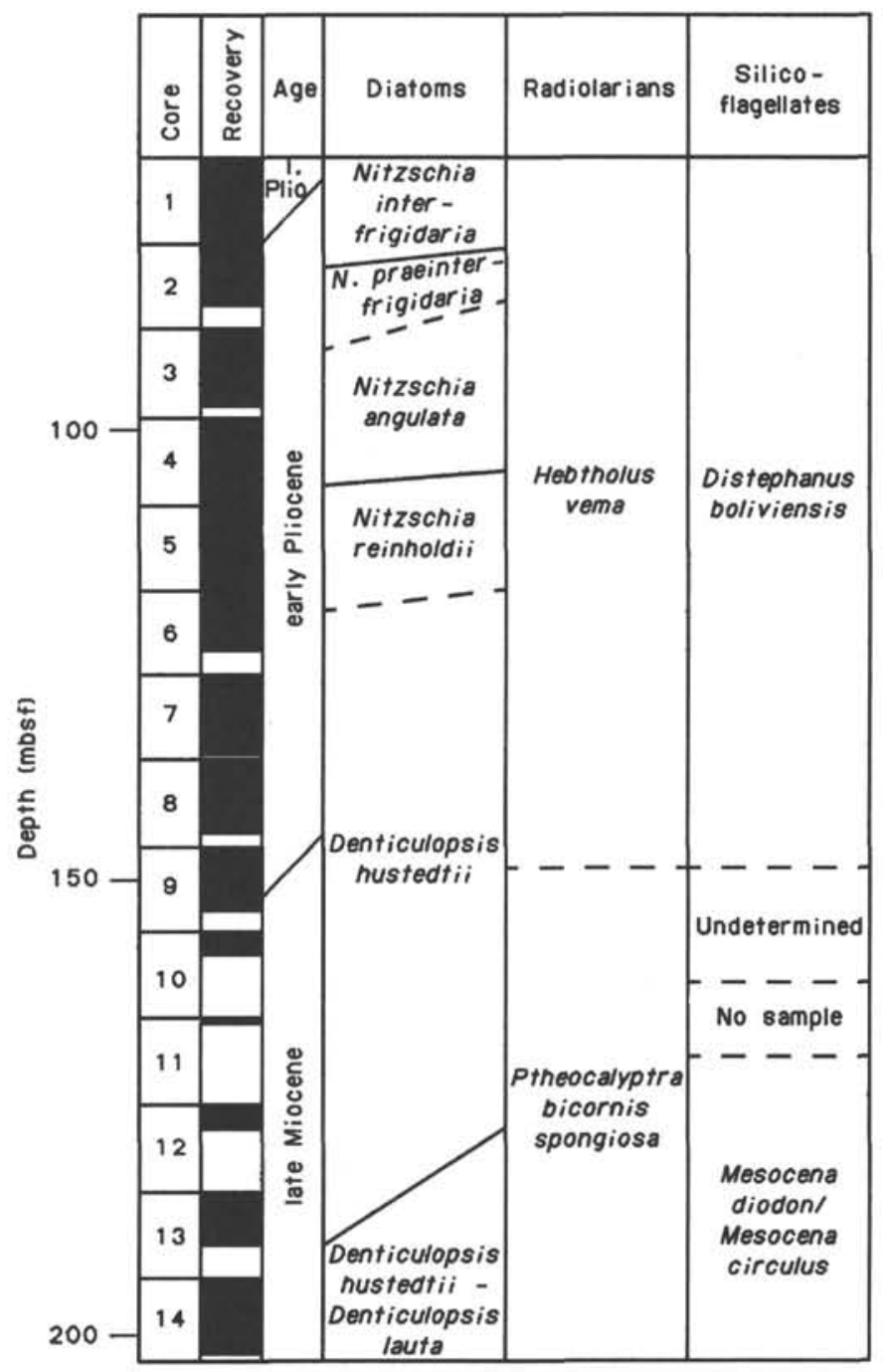

Figure 15. Hole 701B chronostratigraphic summary.

cording to Jenkins' (1985) zonation, because of the absence of the dissolution-resistant Globigerinatheka index and the presence of a lower middle Eocene assemblage similar to that encountered at previous Leg 114 sites.

In agreement with the results from Sites 698, 699, and 700, the lower middle Eocene assemblage has the following characteristics: great abundance of $A$. primitiva, low-diversity and rarity of the other acarininids (single or sparse occurrences of Acarinina pseudotopilensis, Acarinina bullbrooki, Acarinina spinuloinflata, and Acarinina cf. broedermanni) and other biconvex subacute acarininids, few Globigerinatheka senni, and a great abundance of low-spired subbotinids such as Subbotina patagonica, Subbotina eocaenica irregularis, and Subbotina eocaena group. The subbotinids/acarininids ratio is approximately $10 \%$, considering the great abundance of the almost endemic species $A$. primitiva, which is rare in the middle Eocene at low to middle latitudes, where it seems to be replaced by $A$. bullbrooki. The occurrence of Planorotalites with common Pseudotartigerina micra and Pseudotartigerina danvillensis is indicative of the P10 Zone or lower part of the P11 Zone, according to calibration with the magnetostratigraphy at Hole 702B.

Planktonic foraminifers are the first group among calcareous fossils to disappear upward through the sequence in Hole 701C. Disappearance resulting from dissolution proceeded rapidly af- 


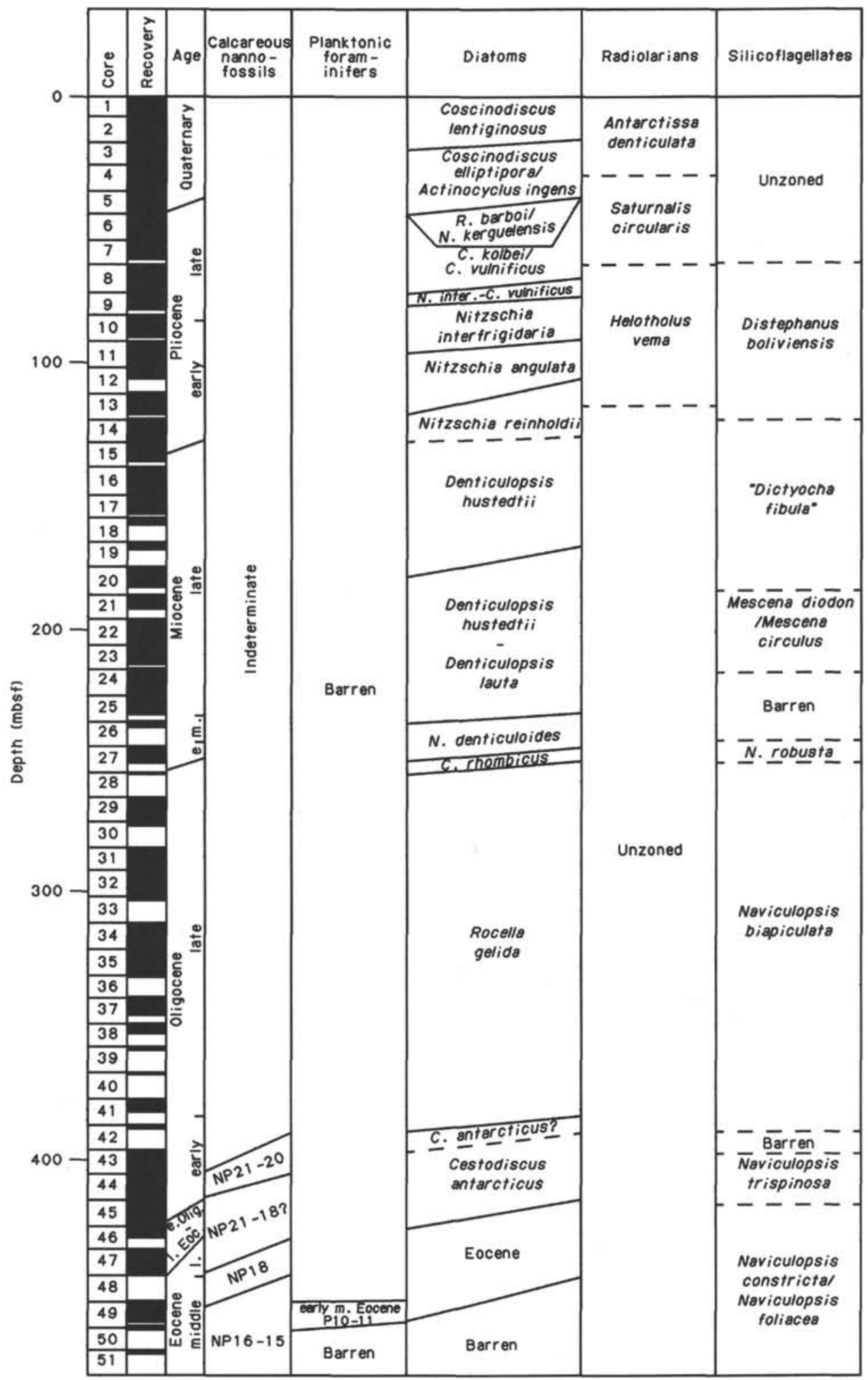

Figure 16. Hole $701 \mathrm{C}$ chronostratigraphic summary.

ter the early middle Eocene. A comparison of the last occurrences (LOs) of planktonic foraminifers at Sites 699, 700, and 701 reveals that the disappearance of planktonic foraminifers is a diachronous event that occurred earlier and more abruptly proceeding from Site 699 toward Site 701. The LO at Site 699 is lower Oligocene, upper middle Eocene at Site 700, and lower middle Eocene at Site 701. This apparent diachroneity is a func- tion of the relative position of hiatuses and the paleodepth differentials of the sites.

\section{Benthic Foraminifers}

Core-catcher samples from Cores 114-701A-1H to 114-701A$8 \mathrm{H}$ were examined for benthic foraminifers and found to be barren. Samples from Sections 114-701B-10H, CC, to 114-701A- 


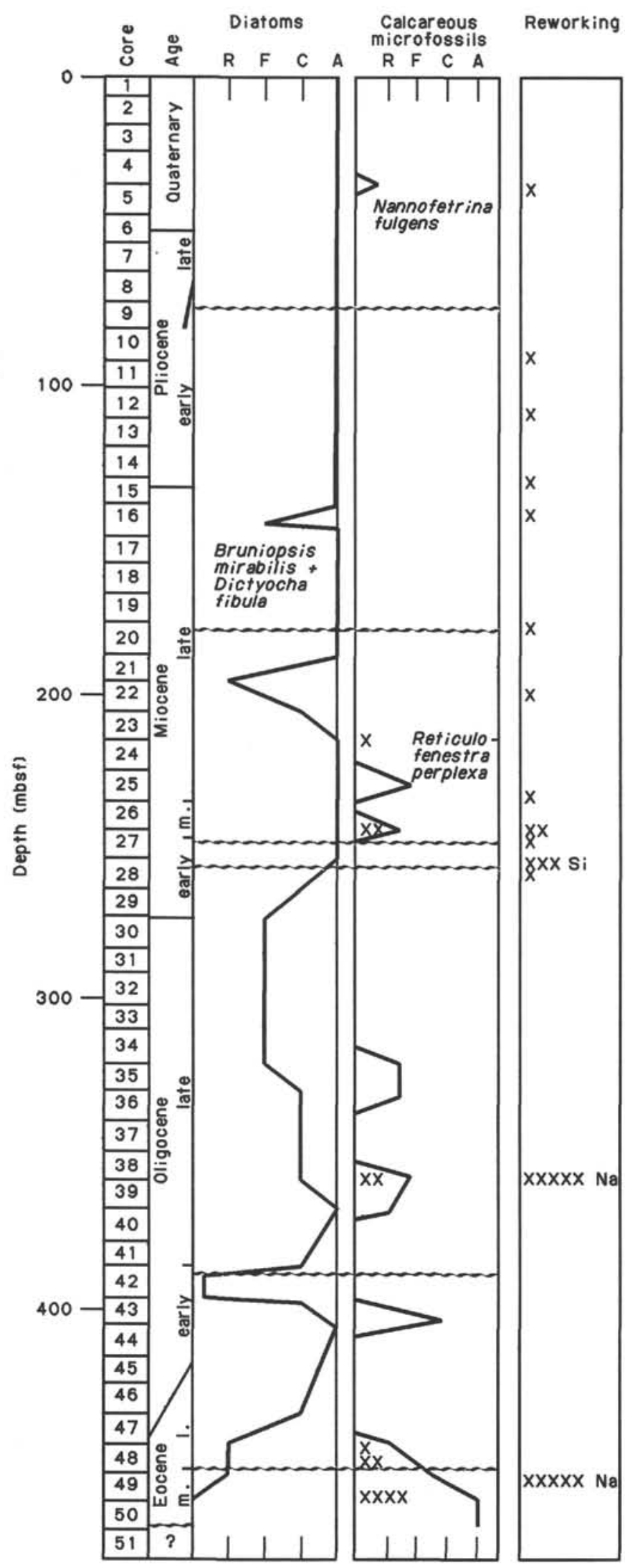

Figure 17. Relative abundance of diatoms and calcareous microfossils in Hole 701C. Undulated lines indicate hiatuses. Crosses indicate the presence and abundance of planktonic foraminifers. Reworking was determined with diatoms unless indicated otherwise: $\mathrm{Na}=$ reworked nannofossils; $\mathrm{Si}=$ reworked silicoflagellates.
$14 \mathrm{X}, \mathrm{CC}$, are barren or nearly barren, with only few occurrences of one or two specimens of Cyclammina sp. or Martinottiella $\mathrm{sp.}$

Similarly, Sections 114-701C-1H, CC, to 114-701A-50X, CC, are barren or nearly barren, with a few exceptions. Section 114701C-23H, CC, contains several specimens of Spirosigmoilinella compressa. Section 114-701C-26X, CC, consists of a sparse fauna of Cyclammina sp., Fissurina sp., Globocassidulina subglobosa, Gyroidinoides sp., Martinottiella sp., Melonis sphaeroides, and Oridorsalis sp. Section 114-701C-38X, CC, contains Gyroidinoides sp., Martinottiella sp., Pullenia bulloides, Pullenia eocaenica, Oridorsalis sp., and Stilostomella spp. Section 114-701C-47X, CC, has a single specimen of Oridorsalis sp. Section 114-701C-48X, CC, contains a few well-preserved Fissurina sp., G. subglobosa, and Nuttallides truempyi. Section 114-701C-49X, CC, contains a rich, well-preserved fauna of Alabamina dissonata, Bulimina glomarchallengeri, Bulimina semicostata, Cibicidoides eocaenus, Cibicidoides havanensis, Cibicidoides cf. pseudoperlucidus, Cibicidoides praemundulus, Cibicidoides subspiratus, Hanzawaia ammophilus, Anomalinoides capitatus, Nonion havanensis, $N$. truempyi, $P$. bulloides, P. eocaenica, Pullenia quinqueloba, Spiroplectammina spectabilis, and the undifferentiated taxa Dentalina sp., Gyroidinoides sp., Lenticulina sp., Nonion sp., Pleurostomella sp., and Stilostomella spp. The good preservation of the Eocene assemblage in Section 114-701C-49X, CC, suggests that the fauna is in situ. The co-occurrences of buliminids, Lenticulina spp., and $H$. ammophilus with abundant $A$. dissonata and the absence of Osangularia mexicana support an Eocene paleodepth of $2500-3000 \mathrm{~m}$.

\section{Diatoms}

Large sections of the Neogene biosiliceous sediments cored at Site 701 consist of pure diatom ooze with only a small admixture of other siliceous microfossils, volcanic ash, and clay. The relative abundance of diatoms in Hole $701 \mathrm{C}$, together with those of the other microfossil groups, is shown in Figure 17.

The preservation of diatoms is good in the Neogene but is moderate to poor in parts of the Oligocene. Large portions of the Eocene are missing in this hole (compare to the preceding calcareous microfossils of this site), and silica dissolution becomes very strong in this interval. Below Core 114-701C-48X diatoms have been completely dissolved, and the authigenic silicate clinoptilolite is found in the silt fraction (see Fig. 17).

Reworking of diatoms seems to have been of minor importance in the Oligocene and Neogene sediments. Single reworked Oligocene diatom valves are found in the early and middle Miocene sediments, and single middle Miocene specimens were found sporadically reworked in upper Miocene, Pliocene, and Quaternary sediments.

\section{Hole $701 \mathrm{~A}$}

Sample 114-701A-1H-2, $87 \mathrm{~cm}$, to Section 114-701C-2H, $\mathrm{CC}$, contain a rich upper Quaternary diatom flora belonging to the Coscinodiscus lentiginosus Zone McCollum (1975) with Nitzschia kerguelensis, Thalassiothrix longissima, Thalassiosira lentiginosa, and Eucampia antarctica as the dominant species. In Sample 114-701A-3H-1, $75 \mathrm{~cm}$, Actinocyclus ingens was found and in Sample 114-701A-5H-2, $140 \mathrm{~cm}$, Rhizosolenia barboi. These two last appearance datums (LADs) place the interval from Samples 114-701A-3H-1, $75 \mathrm{~cm}$, to 114-701A-5H-2, 36 $\mathrm{cm}$, in the Coscinodiscus elliptipora/ $A$. ingens Zone of Weaver and Gombos (1981). The LAD of Coscinodiscus kolbei in Sample 114-701A-5H-5, $114 \mathrm{~cm}$, places the interval from Samples $114-701 \mathrm{~A}-5 \mathrm{H}-2,140 \mathrm{~cm}$, to $114-701 \mathrm{~A}-5 \mathrm{H}-3,70 \mathrm{~cm}$, in the $R$. barboi/N. kerguelensis Zone of Weaver and Gombos (1981). Sample 114-701A-5H-5, $114 \mathrm{~cm}$, to Section 114-701A-6H, CC, fall in the C. kolbei/R. barboi Zone of Ciesielski (1983), with 
Table 5. Site 701 diatom zone correlations.

\begin{tabular}{|c|c|c|c|}
\hline \multirow[b]{2}{*}{ Zone } & \multicolumn{3}{|c|}{ Interval } \\
\hline & Hole 701A & Hole 701B & Hole $701 \mathrm{C}$ \\
\hline Coscinodiscus lentiginosus & $1 \mathrm{H}, \mathrm{CC}-2 \mathrm{H}, \mathrm{CC}$ & & $1 \mathrm{H}, \mathrm{CC}-2 \mathrm{H}, \mathrm{CC}$ \\
\hline Coscinodiscus elliptipora/Actinocyclus ingens & $3 \mathrm{H}-1,75 \mathrm{~cm}-5 \mathrm{H}-2,36 \mathrm{~cm}$ & & $3 \mathrm{H}-2,100 \mathrm{~cm}-5 \mathrm{H}-2,80 \mathrm{~cm}$ \\
\hline Rhizosolenia barboi/Nitzschia kerguelensis & $5 \mathrm{H}-2,140 \mathrm{~cm}-5 \mathrm{H}-3,70 \mathrm{~cm}$ & & $5 \mathrm{H}-4,49 \mathrm{~cm}$ \\
\hline Coscinodiscus kolbei/R. barboi & $5 \mathrm{H}-5,114 \mathrm{~cm}-6 \mathrm{H}, \mathrm{CC}$ & & $5 \mathrm{H}-5,70 \mathrm{~cm}-7 \mathrm{H}-4,60 \mathrm{~cm}$ \\
\hline Coscinodiscus vulnificus & $7 \mathrm{H}-3,77 \mathrm{~cm}-8 \mathrm{H}-1,19 \mathrm{~cm}$ & & $7 \mathrm{H}, \mathrm{CC}-8 \mathrm{H}-3,100 \mathrm{~cm}$ \\
\hline Nitzschia interfrigidaria/C. vulnificus & $8 \mathrm{H}-4,46 \mathrm{~cm}-8 \mathrm{H}, \mathrm{CC}$ & & $8 \mathrm{H}-6,120 \mathrm{~cm}-9 \mathrm{H}-1,120 \mathrm{~cm}$ \\
\hline$N$. interfrigidaria & & $1 \mathrm{H}-1,81 \mathrm{~cm}-2 \mathrm{H}-1,55 \mathrm{~cm} 9 \mathrm{H}-4,100 \mathrm{~cm}-10 \mathrm{H}, \mathrm{CC}$ & \\
\hline Nitzschia praeinterfrigidaria & & $2 \mathrm{H}-2,135 \mathrm{~cm}-2 \mathrm{H}, \mathrm{CC}$ & \\
\hline Nitzschia angulata & & $3 \mathrm{H}-2,88 \mathrm{~cm}-4 \mathrm{H}-4,132 \mathrm{~cm} 11 \mathrm{H}-3,100 \mathrm{~cm}-12 \mathrm{H}, \mathrm{CC}$ & \\
\hline Nitzschia reinholdii & & $4 \mathrm{H}-5,119 \mathrm{~cm}-5 \mathrm{H}, \mathrm{CC} 13 \mathrm{H}, \mathrm{CC}-14 \mathrm{H}-5,38 \mathrm{~cm}$ & \\
\hline Denticulopsis hustedtii & & $6 \mathrm{H}-2,89 \mathrm{~cm}-11 \mathrm{X}, \mathrm{CC} 14 \mathrm{H}, \mathrm{CC}-19 \mathrm{H}, \mathrm{CC}$ & \\
\hline D. hustedtii/Denticulopsis lauta & & $12 \mathrm{X}, \mathrm{CC}-14 \mathrm{X}, \mathrm{CC} 20 \mathrm{H}-1,100 \mathrm{~cm}-25 \mathrm{X}, \mathrm{CC}$ & \\
\hline Nitzschia denticuloides & & & $26 \mathrm{X}, \mathrm{CC}-27 \mathrm{X}-2,100 \mathrm{~cm}$ \\
\hline Coscinodiscus rhombicus & & & $27 \mathrm{X}, \mathrm{CC}$ \\
\hline Rocella gelida & & & $28 \mathrm{X}, \mathrm{CC}-41 \mathrm{X}, \mathrm{CC}$ \\
\hline Cestodiscus antarcticus & & & $42 \mathrm{X}, \mathrm{CC}-44 \mathrm{X}, \mathrm{CC}$ \\
\hline
\end{tabular}

Table 6. Reworked nannofossil species and their ages, Hole 701C.

\begin{tabular}{lll}
\hline \multicolumn{1}{c}{ Sample } & \multicolumn{1}{c}{ Reworked nannofossils } & \multicolumn{1}{c}{ Age } \\
\hline $34 \mathrm{X}, \mathrm{CC}$ & Chiasmolithus altus & NP22-25 \\
$35 \mathrm{X}, \mathrm{CC}$ & Reticulofenestra daviesi & NP16-25 \\
$38 \mathrm{X}, \mathrm{CC}$ & Reticulofenestra umbilica & NP13-22 \\
& Reticulofenestra bisecta & NP16-25 \\
& R. daviesi & NP16-25 \\
& C. altus & NP22-25 \\
& Cyclicargolithus floridanus & NP20-NN6 \\
$39 \mathrm{X}, \mathrm{CC}$ & R. daviesi & NP16-25 \\
$49 \mathrm{X}-1,27 \mathrm{~cm}$ & Tribrachiatus orthostylus & NP10-12 \\
$49 \mathrm{X}-3,30 \mathrm{~cm}$ & Fasciculithus tympaniformis & NP5-9 \\
\hline
\end{tabular}

Note: All ranges quoted are from by Perch-Nielsen (1985), except for the ranges for $R$. umbilica and $R$. daviesi, which have been modified to conform with the findings of the Leg 114 shipboard investigations.

the LAD of Coscinodiscus vulnificus occurring in Sample 114$701 \mathrm{~A}-7 \mathrm{H}-3,77 \mathrm{~cm}$. In Sample 114-701A-8H-3, $60 \mathrm{~cm}$, Cosmiodiscus insignis occurs, placing this sample in the $C$. insignis Zone Ciesielski (1983) and the interval from Samples 114-701A$7 \mathrm{H}-3,77 \mathrm{~cm}$, to $114-701 \mathrm{~A}-8 \mathrm{H}-1,19 \mathrm{~cm}$, in the $C$. vulnificus Zone Ciesielski (1983). Because of the occurrence of the marker species C. vulnificus, C. insignis, Nitzschia weaveri, and Nitzschia interfrigidaria the lowest part of Hole 701A, the interval from Sample 114-701A-8H-4, $46 \mathrm{~cm}$, to Section 114-701A-8H, $\mathrm{CC}$, falls in the $N$. interfrigidaria/C. vulnificus Zone Ciesielski (1983).

\section{Hole $701 B$}

Hole 701B was washed down to $70 \mathrm{mbsf}$, i.e., approximately $5 \mathrm{~m}$ above the total depth of Hole 701A. From the biostratigraphic results of the diatom analysis it seems that no stratigraphic overlap was achieved.

In Sample 114-701B-1H-1, $81 \mathrm{~cm}, C$. vulnificus was not present, but $N$. interfrigidaria and $N$. weaveri were found. This sample, as well as Sample 114-701B-2H-1, $55 \mathrm{~cm}$, belong in the N. interfrigidaria Zone Ciesielski (1983). Below Sample 114 $701 \mathrm{~B}-2 \mathrm{H}-1,55 \mathrm{~cm}, N$. weaveri is absent, and below Section 114$701 \mathrm{~B}-2 \mathrm{H}, \mathrm{CC}, N$. interfrigidaria disappears, placing the interval from Sample 114-701B-2H-2, $135 \mathrm{~cm}$, to Section 114-701B-2H, $\mathrm{CC}$, in the Nitzschia praeinterfrigidaria Zone Ciesielski (1983). Because of the FAD of Nitzschia angulata in Sample 114-701B$4 \mathrm{H}-4,132 \mathrm{~cm}$, the interval from Samples 114-701B-3H-2, 88 $\mathrm{cm}$, to $114-701 \mathrm{~B}-4 \mathrm{H}-4,132 \mathrm{~cm}$, falls in the $N$. angulata Zone of
Weaver and Gombos (1981). Denticulopsis hustedtii, the LO of which defines the top of the D. hustedtii Zone McCollum (1975), has only very scattered occurrences at Site 701 and, therefore, does not provide a reliable datum in Holes 701B and 701C. For that reason the boundary between the Nitzschia reinholdii Zone Weaver and Gombos (1981) and the underlying D. hustedtii Zone Weaver and Gombos (1981) cannot be well defined at the present time. Within the $D$. hustedtii Zone a mass occurrence of Bruniopsis mirabilis is present from the top of Core 114-701B$9 \mathrm{H}$ to Core 114-701B-12X. Downcore from Section 114-701B$13 \mathrm{X}, \mathrm{CC}$, Denticulopsis lauta is present, which places the last two cores of this hole in the $D$. hustedtii/D. lauta Zone Weaver and Gombos (1981).

\section{Hole $701 C$}

Intervals with reworked diatoms were found in the attenuated lower and middle Miocene sections, and sporadic, rare finds of reworked diatoms occurred throughout the rest of the overlying Neogene (Fig. 17).

Section 114-701C-1H, CC, through Sample 114-701C-3H-2, $100 \mathrm{~cm}$, represent the C. lentiginosus Zone McCollum (1975). The interval between Samples 114-701C-3H-4, $99 \mathrm{~cm}$, through 114-701C-8H-3, $100 \mathrm{~cm}$, includes the $C$. elliptipora Zone, $R$. barboi/N. kerguelensis Zone, C. kolbei/R. barboi Zone, and C. vulnificus Zone of the basal Brunhes-Matuyama Chrons.

The joint last appearances of $N$. weaveri and $N$. interfrigidaria in Sample 114-701C-8H-6, $120 \mathrm{~cm}$, suggest the presence of a hiatus between this sample and the top of the Gauss Chronozone between Samples 114-701C-8H-2, $78 \mathrm{~cm}$ and 114-701C$8 \mathrm{H}-5,70 \mathrm{~cm}$. The hiatus includes the $N$. weaveri Zone and probably some portions of the overlying $C$. insignis Zone and underlying $N$. interfrigidaria/C. vulnificus Zone. The duration of this hiatus is $\sim 0.5 \mathrm{Ma}$, extending from $\sim 3.0$ to $2.5 \mathrm{Ma}$.

The short interval immediately beneath the upper Pliocene hiatus (72.0-67.3 mbsf) and between Samples 114-701C-8H-6, $120 \mathrm{~cm}$, and $114-701 \mathrm{C}-9 \mathrm{H}-1,120 \mathrm{~cm}$, represents the mid-Gauss Chron $N$. interfrigidaria/C. vulnificus Zone.

The presence of $N$. interfrigidaria and $N$. weaveri identifies the interval from Sample 114-701C-9H-4, $100 \mathrm{~cm}$, to Section 114-701C-10H, CC , as belonging to the $N$. interfrigidaria Zone Ciesielski (1983). Following Ciesielski (1983), the interval between the first occurrences (FOs) of $N$. angulata and $N$. interfrigidaria, from Sections 114-701C-10H, CC, to $114-701 \mathrm{C}-11 \mathrm{H}$, $\mathrm{CC}$, was assigned to the $N$. angulata Zone. Sections 114-701C$12 \mathrm{H}, \mathrm{CC}$, through $114-701 \mathrm{C}-15 \mathrm{H}, \mathrm{CC}$, appear to represent the $N$. reinholdii Zone and the lower Pliocene part of the $D$. hu- 


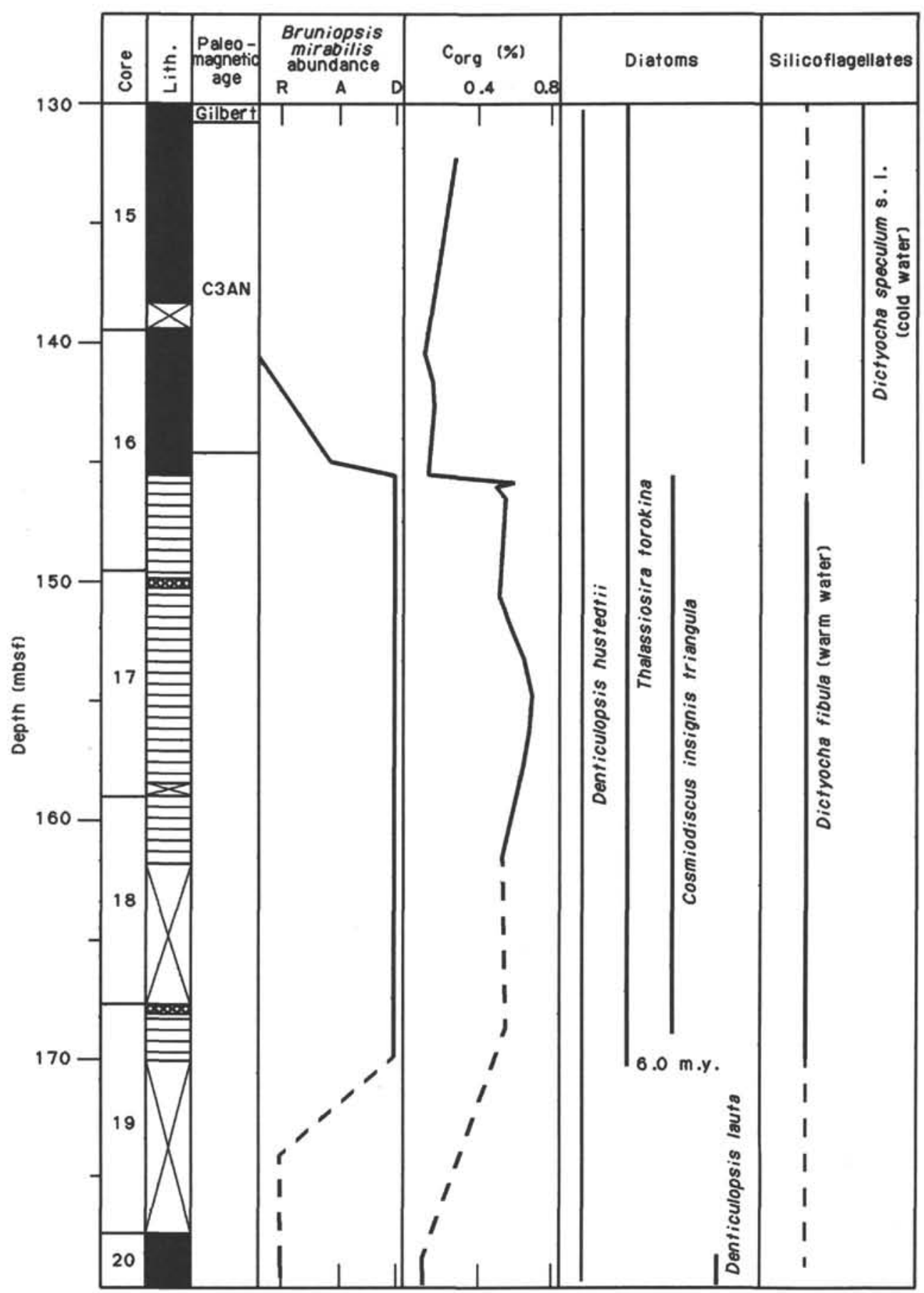

Figure 18. The interval of the laminated Bruniopsis mirabilis ooze in Hole 701C, showing the relative abundance of $B$. mirabilis $(\mathrm{R}=$ rare, $\mathrm{A}=$ abundant, $\mathrm{D}=$ dominant $)$, the organic carbon content, the presence and relative abundance of stratigraphically and ecologically important diatom and silicoflagellate species in relation to the recovered sediments, and paleomagnetic age assignment.

stedtii Zone; however, it is not yet possible to place the boundary between these zones because of the difficulty in interpreting the LO of $D$. hustedtii. The interval from Sections 114-701C$15 \mathrm{H}, \mathrm{CC}$, to $114-701 \mathrm{C}-19 \mathrm{H}, \mathrm{CC}$, was placed in the $D$. hustedtii Zone Weaver and Gombos (1981). Because of the occurrence of Nitzschia denticuloides in Section 114-701C-22H, CC, through Sample 114-701C-27X-2, $100 \mathrm{~cm}$, this interval belongs in the $N$. denticuloides Zone, and the overlying interval from this zone to the LO of D. lauta in Sample $114-701 \mathrm{C}-20 \mathrm{H}-1,100 \mathrm{~cm}$, is placed in the $D$. hustedtii-D. lauta Zone Weaver and Gombos
(1981). In Section 114-701C-27X, CC, Coscinodiscus rhombicus was found together with Nitzschia maleinterpretaria and Denticulopsis mccollumii, which places this sample in the $C$. rhombicus Zone of Weaver and Gombos (1981). From Sections 114-701C-28X, CC, to 114-701C-41X, CC, Rocella gelida occurs together with Raphidodiscus marylandicus, Bogorovia veniamini, Rossiella symmetrica, and rare Hemiaulus incisus, so that this interval belongs to the lowermost Miocene-uppermost Oligocene $R$. gelida Zone Fenner (1984). In Core 114-701C-42X the very poor preservation of diatoms is probably related to in- 
tensified silica dissolution during the interval of nondeposition and/or erosion responsible for the absence of lower upper to upper lower Oligocene sediments. Sample 114-701C-43X-1, 30 $\mathrm{cm}$, to Section 114-701C-44X, CC, were assigned to the lowermost Oligocene Cestodiscus antarcticus Zone Fenner (1984) because of the presence of the name-giving species and a number of other characteristic Cestodiscus and Hemiaulus species, as well as Pyxilla reticulata (prolongata type), and the absence of Rylandsia inaequiradiata.

In Core 114-701C-45X and below, preservation of diatoms is poor and their abundance rare. Therefore, age assignment by diatoms is not accurate for this interval. Sections 114-701C$45 \mathrm{X}, \mathrm{CC}$, to $114-701 \mathrm{C}-46 \mathrm{X}, \mathrm{CC}$, are probably late Eocene and Sections 114-701C-47X, CC, to 114-701C-48X, CC, possibly middle Eocene in age. In Section 114-701C-47X, CC, a fragment of Craspedodiscus oblongus was found. Sections 114701C-49X, CC, to 114-701C-51X, CC, are barren of diatoms.

The correlation of the holes based on diatom datums is summarized in Table 4 and Figures 14 through 16.

The diatom assemblage throughout this hole is characteristic of an open-marine environment. As in Hole 699A, the Eocene and lower Oligocene diatom assemblages have several characteristic warm-water species and cosmopolitan species present, which disappear in the overlying sediments. From the lower and middle Miocene and above, an increasingly endemic subantarctic assemblage was found, a change that reflects the development of the ACC.

A feature of special interest is the finely laminated diatomite occurring from Sample 114-701C-16H-5, $24 \mathrm{~cm}$, down to Section $114-701 \mathrm{C}-19 \mathrm{H}, \mathrm{CC}$, which is the same interval as Core 114$701 \mathrm{~B}-9 \mathrm{H}$ to Section 114-701B-12H, CC. In this interval, laminae consisting of the gigantic diatom species $B$. mirabilis (up to $99 \%$ of the composition) alternate either with laminae that have a higher content of one or two other diatom species (such as Thalassionema nitzschioides or Thalassiosira, Nitzschia, or Coscinodiscus species) or with laminae in which B. mirabilis occurs together with the silicoflagellate Dictyocha fibula (Fig. 17). In other laminae a greater number of other species occur, and some laminae are rich in pyrite(?)-coated diatoms and radiolarians.

According to the paleomagnetic reversal record (see "Paleomagnetics" section), the finely laminated $B$. mirabilis-dominated ooze lies below Chron C3AN, so it is older than 5.9 m.y. The FO of Thalassiosira torokina was found at the base of Core $114-701 \mathrm{C}-19 \mathrm{H}$, and the LO of D. lauta was found at the top of Core 114-701C-20H. Based on correlation to the paleomagnetic reversal record in two piston cores, Brady (Ciesielski, 1986) placed the FAD of $T$. torokina at about 6 m.y. Although this latter datum needs further confirmation, if it is correct, these two datums indicate the following:

1. Only a very short time interval would be available for the deposition of this more than 20 -m-thick ooze. The accurate determination of the FAD of $T$. torokina is critical for evaluating the time involved in the deposition of this nearly monospecific ooze.

2. A hiatus is present at the base of the Bruniopsis ooze.

Such Bruniopsis oozes are also reported from other south Atlantic DSDP sites. In the literature, similar nearly monospecific oozes of a giant diatom species, the Ethmodiscus oozes, are regarded as representing blooms of this species-possibly in a dysotrophic habitat-or dissolution relicts. Alternatively, they have been interpreted as products of current transport and winnowing (for review of the literature and discussion see Mikkelsen, 1977). B. mirabilis is, of course, a different and, unfortunately, extinct species, which might have had different ecological preferences than Ethmodiscus rex. The Bruniopsis ooze at Site 701 probably results from a combination of special oceanographic conditions that led to blooms of $B$. mirabilis and winnowing processes at the seafloor.

The organic carbon content in the Bruniopsis ooze is higher (average $0.6 \%$ ) than that in the sediment above and below (average $0.1 \%-0.34 \%$ ). Silicoflagellates (see the following in this section) suggest a warm-water influence for the period of deposition of the laminated Bruniopsis ooze.

\section{Radiolarians}

Core-catcher samples from Site 701 contained common to abundant and well-preserved radiolarians. By adopting Hays and Opdyke's (1967) and Chen's (1975) zonal scheme as a guide, the biostratigraphic distribution of radiolarians from Site 701 can be summarized as follows:

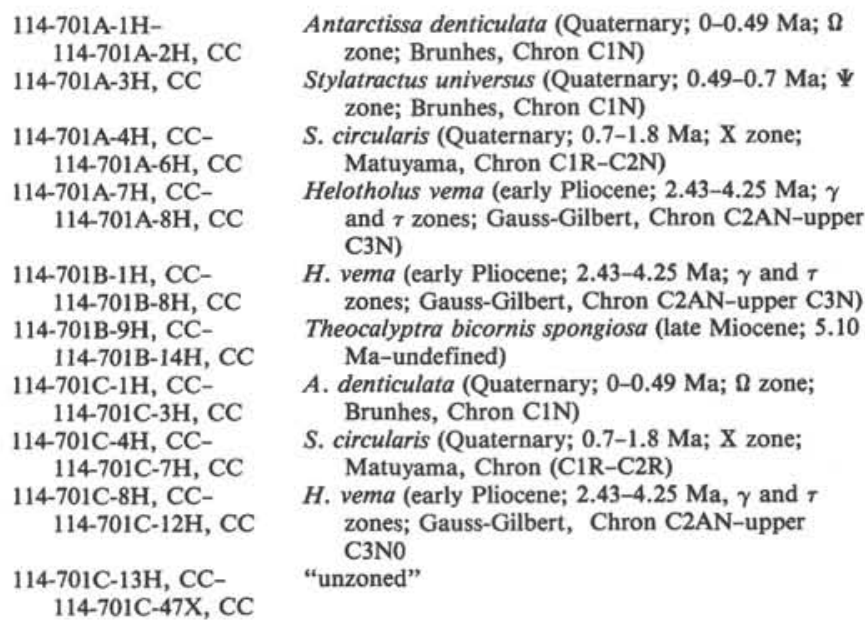

Antarctissa denticulata (Quaternary; 0-0.49 Ma; $\mathbf{0}$ zone; Brunhes, Chron C1N)

Stylatractus universus (Quaternary; $0.49-0.7 \mathrm{Ma} ; \Psi$ zone; Brunhes, Chron C1N)

$S$. circularis (Quaternary; 0.7-1.8 Ma; X zone; Matuyama, Chron C1R-C2N)

Helotholus vema (early Pliocene; 2.43-4.25 Ma; $\gamma$ and $\tau$ zones; Gauss-Gilbert, Chron C2AN-upper $\mathrm{C} 3 \mathrm{~N})$

$H$. vema (early Pliocene; $2.43-4.25 \mathrm{Ma} ; \gamma$ and $\tau$ zones; Gauss-Gilbert, Chron C2AN-upper C3N)

Theocalyptra bicornis spongiosa (late Miocene; 5.10 Ma-undefined)

A. denticulata (Quaternary; 0-0.49 Ma; 8 zone; Brunhes, Chron C1N)

S. circularis (Quaternary; 0.7-1.8 Ma; X zone; Matuyama, Chron (C1R-C2R)

$H$. vema (early Pliocene; $2.43-4.25 \mathrm{Ma}, \gamma$ and $\tau$ zones; Gauss-Gilbert, Chron C2AN-upper C3NO

"unzoned"

In Sections $114-701 \mathrm{C}-1 \mathrm{H}, \mathrm{CC}$, through $114-701 \mathrm{C}-3 \mathrm{H}, \mathrm{CC}$, the absence of the index form, Stylatractus universus, makes it difficult to verify the presence of the $S$. universus Zone in this interval at the present time.

In the "unzoned" interval, the occurrence of Cyrtocapsella japonica in Section 114-701C-13H, CC, suggests that the sample is probably of late Miocene age on the basis of the Leg 71 observations by Weaver (1983). In Sections 114-701C-14H, CC, to $114-701 \mathrm{C}-47 \mathrm{X}, \mathrm{CC}$, which encompass the lowermost Pliocene through the middle Eocene to lower Oligocene, most of the guide fossils selected by Chen (1975) for the Miocene sequence are absent. Furthermore, no radiolarian zonation is available for the Paleogene section of the southern high-latitude region. It should be noted, however, that Sections 114-701C-43H, CC, through 114-701C-47, CC (lower Oligocene-upper Eocene) contain unusually large specimens of a few new species that may be assigned to the genus Thyrsocyrtis. Judging from their stratigraphic position and faunal composition, the samples are probably correlative with the interval that Weaver (1983; also in Shaw and Ciesielski, 1983) indicated as "Thyrsocyrtis bromia and equivalent."

\section{Silicoflagellates}

Core-catcher samples from Site 701 were observed to contain common to rare and moderately well-preserved silicoflagellates. The biostratigraphic distribution of silicoflagellates summarized in the following generally follows the zonal scheme proposed by Shaw and Ciesielski (1983). The consistent occurrence of Distephanus boliviensis in Pliocene sediments from both Holes 701A and 701B suggests that the $D$. boliviensis Zone may be applicable to this region. This zone was recognized earlier in the North Pacific (Ling, 1973) and the Pacific sector of the antarctic (Ciesielski, 1975). 


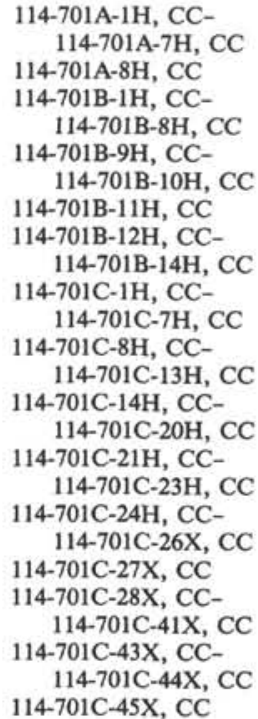

\section{"unzoned" (Quaternary-late Pliocene)}

Distephanus boliviensis (early Pliocene)

D. boliviensis (early Pliocene)

"undetermined"

no samples

Mesocena diodon/Mesocena circulus (late Miocene)

"unzoned" (Quaternary-late Pliocene)

D. boliviensis (early Pliocene)

"Dictyocha fibula"

M. diodon/M. circulus (late Miocene)

barren

Naviculopsis robusta (early Miocene)

Naviculopsis biapiculata (late Oligocene)

Naviculopsis trispinosa (early Oligocene)

Naviculopsis constricta/Naviculopsis foliacea (late Eocene)

The consistent occurrence of Dictyocha fibula in Sections 114-701C-14H, CC, to 114-701C-20H, CC, in significant abundance in Section 114-701C-16H, CC, is surprising in this highlatitude region. Based on the modern biogeographic distribution, the species is restricted to warm waters of the low to temperate latitudes. It is also interesting to note that the diatomaceous ooze in Sections $114-701 \mathrm{C}-16 \mathrm{H}-5$ to $114-701 \mathrm{C}-19 \mathrm{H}$ consists exclusively of the diatom genus Bruniopsis (J. M. Fenner, pers. comm., 1987). The significance of this unique sediment and the abundant occurrence of a warm-water species in a high-latitude region warrant further detailed investigation. Section 114-701C-27X, CC, contains numerous fragments of several silicoflagellate species, and this phenomenon also requires further consideration.

\section{Ebridians}

Rare to few occurrences of ebridians were noted in numerous samples from this site; however, the LOs of the following species may have biostratigraphic significance for this area:

\section{4-701A-8H, CC $114-701 \mathrm{~B}-1 \mathrm{H}, \mathrm{CC}$ 114-701C-9H, CC 114-701C-45X, CC \\ Ebriopsis antiqua antiqua (early Pliocene) \\ $E$. antiqua antiqua (early Pliocene) \\ $E$. antiqua antiqua (early Pliocene) \\ Ammodochium ampulla and Ebriopsis crenulata (late Eocene)}

It should be noted here that no specimens referable to Ebriopsis antiqua cornuta were observed at this site. Joint occurrences of $E$. antiqua antiqua and Ebriopsis antiqua cornuta have been reported from numerous marine and terrestrial lower Pliocene and Miocene sequences in various parts of the world. The geological occurrence of both Ammodochium ampulla and Ebriopsis crenulata is limited to the Eocene in the Antarctic Ocean (Perch-Nielsen, 1975).

\section{Paleoenvironment}

Based on examination of core-catcher samples, the middle Miocene sediments of Sections 114-701C-26X, CC, and 114701C-27X, CC, were deposited under a warm-water influence, as suggested by the recovery of the radiolarians Cyrtocapsella tetrapera and Lamprocyclas maritalis maritalis. Warm surfacewater conditions are also inferred for the upper Miocene section (Sections 114-701C-16H, CC, through 114-701C-20H, CC), where the consistent rare to abundant occurrence of a typical warmwater silicoflagellate species, D. fibula, was observed. Beginning from the early Pliocene and throughout the Quaternary, Site 701 apparently remained close to or south of the polar front, because radiolarian and silicoflagellate assemblages consist entirely of cold-water forms, and none of the subantarctic species listed by Weaver (1983) from Site 514 was encountered.

\section{GEOCHEMISTRY}

Pore waters were squeezed from seventeen 5 - or $10-\mathrm{cm}$ wholeround core samples taken from Holes 701A, 701B, and $701 \mathrm{C}$ at about $30-\mathrm{m}$ intervals throughout the entire section. The results of the pore-water chemistry are reported in Table 7 and Figure 19. One pore-water sample (114-701C-9H-5, 46-50 cm; 150 mbsf) consists of half of the working half of the core, taken approximately $6 \mathrm{hr}$ after retrieval. The pore-water chemistry from this sample shows significant differences from adjacent samples for constituents such as dissolved silica, fluoride, and alkalinity, but not for calcium and magnesium.

Volatile hydrocarbon gases from headspace samples were analyzed throughout the section (Table 8). Sedimentary organic carbon and calcium carbonate were determined on every section (Table 9).

The major lithostratigraphic intervals influence the pore-water signatures. Lithostratigraphic Unit I (0-243.8 mbsf) is dominantly Neogene clay-bearing biosiliceous sediment containing common ash horizons in its upper part (0-147 mbsf). This unit also contains an organic-carbon-rich upper Miocene laminated diatomite (Bruniopsis mirabilis ooze) in the interval 147.5-174.8 mbsf in Hole 701B. Lithostratigraphic Unit III (452.8-481.3 mbsf) is a middle Eocene indurated nannofossil chalk containing no diatoms but with abundant zeolites (clinoptilolite), which increase in abundance toward the base of the unit. No chert was recovered in this hole.

\section{Interstitial-Water Chemistry}

Pore-water chemistry at Site 701 reflects reactions within the sediment column (weathering of volcanic ash and silica diagenesis) and the presence of low-salinity formation waters of uncertain origin.

\section{Salinity and Chloride}

Salinity and chloride values at the top of the sediment column reflect the salinity of the overlying water column. Below the sediment/water interface, both chloride and salinity decrease erratically with depth. At $400 \mathrm{mbsf}$, chloride and salinity display values that are nearly $3 \%$ lower than in the upper portion of the section. These profiles are similar to the salinity and chloride signatures obtained at Site 699 , and are very unusual for pelagic, organic-carbon-poor sediments not containing methane hydrates. As mentioned in the "Geochemistry" section of the "Site 699" chapter, these salinity profiles are difficult to explain as steady-state features. It is worth noting that only the two deepest sites (699 and 701) contain this low-salinity feature. We have considered the possibility that these values are artifacts caused by incomplete drying of the squeezers between uses (dilution by fresh water). The absence of an indirect relationship between pore-water volume expressed and chloride concentration suggests the absence of a dilution artifact, but the possibility cannot be excluded. Chloride and salinity samples from Sites 699,700 , and 701 were found to be accurate upon reanalysis aboard ship.

One possible explanation is that low-salinity bottom water existed in the South Atlantic Ocean during some time in the past. An alternative explanation is the destruction of a previously existing methane hydrate layer created from methane generation in the Bruniopsis mirabilis ooze organic-carbon-rich interval (145-175 mbsf) shortly after it was deposited (late Miocene). The distinct minimum in the salinity and chloride profiles at about 400 mbsf would then be interpreted as a downward-diffusing low-salinity pulse imparted at or near the sediment/water interface. The elapsed time needed to produce such a diffu- 
Table 7. Interstitial-water chemistry data from Site 701.

\begin{tabular}{|c|c|c|c|c|c|c|c|c|c|c|c|c|}
\hline $\begin{array}{l}\text { Sample } \\
(\mathrm{cm})\end{array}$ & $\begin{array}{l}\text { Depth } \\
\text { (mbsf) }\end{array}$ & $\begin{array}{l}\text { Volume } \\
\text { (mL) }\end{array}$ & $\mathrm{pH}$ & $\begin{array}{l}\text { Alkalinity } \\
(\mathrm{mmol} / \mathrm{L})\end{array}$ & $\begin{array}{l}\text { Salinity } \\
(\mathrm{g} / \mathrm{kg})\end{array}$ & $\begin{array}{l}\text { Magnesium } \\
(\mathrm{mmol} / \mathrm{L})\end{array}$ & $\begin{array}{c}\text { Calcite } \\
(\mathrm{mmol} / \mathrm{L})\end{array}$ & $\begin{array}{l}\text { Chloride } \\
(\mathrm{mmol} / \mathrm{L})\end{array}$ & $\begin{array}{l}\text { Sulfate } \\
(\mathrm{mmol} / \mathrm{L})\end{array}$ & $\begin{array}{l}\text { Fluoride } \\
(\mu \mathrm{mol} / \mathrm{L})\end{array}$ & $\begin{array}{c}\text { Silica } \\
(\mu \mathrm{mol} / \mathrm{L})\end{array}$ & $\mathrm{Mg} / \mathrm{Ca}$ \\
\hline \multicolumn{13}{|l|}{ Hole 701A: } \\
\hline $1 \mathrm{H}-4,145-150$ & 5.95 & 110 & 7.69 & 4.21 & 34.8 & 52.67 & 10.99 & 558.00 & 27.30 & 61.60 & 811 & 4.79 \\
\hline $3 \mathrm{H}-4,145-150$ & 23.75 & 116 & 7.73 & 5.00 & 35.0 & 52.32 & 11.35 & 557.00 & 26.80 & 43.60 & 950 & 4.61 \\
\hline $6 \mathrm{H}-5,145-150$ & 53.75 & 75 & 7.69 & 5.66 & 35.0 & 50.59 & 12.13 & 558.00 & 25.40 & 33.90 & 861 & 4.17 \\
\hline \multicolumn{13}{|l|}{ Hole 701B: } \\
\hline $1 \mathrm{H}-5,145-150$ & 77.45 & 75 & 7.62 & 6.03 & 34.8 & 49.51 & 12.13 & 554.00 & 24.50 & 30.90 & 969 & 4.08 \\
\hline $4 \mathrm{H}-5,145-150$ & 105.95 & 96 & 7.59 & 6.19 & 34.6 & 47.95 & 12.87 & 555.00 & 24.40 & 27.70 & 979 & 3.73 \\
\hline $7 \mathrm{H}-4,145-150$ & 132.95 & 63 & 7.58 & 6.33 & 34.2 & 46.50 & 13.29 & 553.00 & 24.10 & 25.60 & 1044 & 3.50 \\
\hline $9 \mathrm{H}-5,46-50$ & 149.96 & 26 & 7.72 & 5.95 & 34.5 & 46.62 & 13.49 & 558.00 & 24.50 & 30.50 & 1320 & 3.46 \\
\hline $13 \mathrm{H}-3,140-150$ & 188.40 & 120 & 7.51 & 6.60 & 34.3 & 45.95 & 14.02 & 557.00 & 23.00 & 28.20 & 1080 & 3.28 \\
\hline \multicolumn{13}{|l|}{ Hole 701C: } \\
\hline $17 \mathrm{H}-5,145-150$ & 155.73 & 77 & 7.74 & 6.47 & 34.6 & 46.62 & 13.67 & 553.00 & 24.09 & 24.20 & 1171 & 3.41 \\
\hline $23 \mathrm{H}-4,140-150$ & 211.70 & 130 & 7.82 & 6.67 & 34.2 & 45.95 & 14.18 & 551.00 & 23.65 & 25.10 & 1063 & 3.24 \\
\hline $27 \mathrm{H}-2,140-150$ & 246.70 & 36 & 7.77 & 6.27 & 34.0 & 45.09 & 14.33 & 549.00 & 23.14 & 27.70 & 1184 & 3.15 \\
\hline $31 X-2,140-150$ & 284.70 & 64 & 7.68 & 6.05 & 34.5 & 45.32 & 14.65 & 550.00 & 23.45 & 27.70 & 962 & 3.09 \\
\hline $34 X-4,140-150$ & 316.20 & 96 & 7.89 & 6.28 & 34.4 & 43.64 & 15.03 & 550.00 & 23.90 & 26.20 & 1028 & 2.90 \\
\hline $37 X-3,140-150$ & 343.20 & 72 & 7.65 & 6.33 & 34.0 & 43.71 & 15.26 & 546.00 & 24.17 & 27.70 & 1083 & 2.86 \\
\hline $42 X-1,140-150$ & 387.70 & 15 & 7.61 & 6.11 & 33.8 & 49.53 & 16.27 & 543.00 & 23.40 & 29.80 & 1192 & 3.04 \\
\hline $45 X-4,140-150$ & 420.70 & 52 & 7.76 & 5.34 & 34.1 & 46.80 & 15.93 & 544.00 & 23.13 & 28.30 & 1167 & 2.94 \\
\hline $49 X-4,140-150$ & 458.70 & 26 & 7.74 & 4.61 & 34.5 & 47.56 & 15.01 & 550.00 & 24.93 & 37.70 & 633 & 3.17 \\
\hline
\end{tabular}

sional feature is approximately $6 \mathrm{~m} . \mathrm{y}$., consistent with both of the above hypotheses. This speculation must be verified by modeling the profiles to constrain the possible magnitudes and timing of salinity changes that could produce the observed features and by analyses for other conservative tracers in these samples.

\section{Calcium and Magnesium}

Calcium concentrations increase downhole from a bottomwater concentration of $10 \mathrm{mmol} / \mathrm{L}$ to a maximum of $16.3 \mathrm{mmol} /$ $\mathrm{L}$ at $387.7 \mathrm{mbsf}$, about $90 \mathrm{~m}$ above basement. Below this depth, calcium concentrations decrease slightly downhole to a concentration of $15 \mathrm{mmol} / \mathrm{L}$ just above the bottom of the hole. Magnesium concentrations decrease downhole from bottom-water concentrations of $55 \mathrm{mmol} / \mathrm{L}$ to a minimum of $43.6 \mathrm{mmol} / \mathrm{L}$ at 316.2 mbsf, about $164 \mathrm{~m}$ above basement. The depth of the magnesium minimum may not be different from that of the calcium maximum; the value for $\mathrm{Mg}$ at $387.7 \mathrm{mbsf}$ (confirmed by replicate analyses of this sample) appears to be too high, for unknown reasons. The magnesium/calcium ratio decreases downhole to a depth of about 350 mbsf, below which it shows some evidence of increasing toward basement.

The calcium and magnesium profiles result from alteration reactions of silicic volcanic ash throughout the upper part of the section (Gieskes and Lawrence, 1981; Gieskes, 1983; Baker, 1986). These sedimentary reactions apparently dominate the $\mathrm{Mg}$ and $\mathrm{Ca}$ profiles so that diffusive exchange between seawater and the underlying basaltic basement reactions do not dominate the $\mathrm{Mg} / \mathrm{Ca}$ ratio. The vertical profiles of $\mathrm{Ca}$ and $\mathrm{Mg}$ at Site 701 are thus nonlinear. A plot of Mg vs. Ca for this site (Fig. 20) shows that the $\Delta \mathrm{Mg} / \Delta \mathrm{Ca}$ trend is nonlinear and has a slope much greater than that for Sites 699 and 700 . Thus, calcium and magnesium are not conservative within the sediment column at this site. The $\Delta \mathrm{Mg} / \Delta \mathrm{Ca}$ slope at Sites 699 and 700 is about -0.5 , whereas at Site 701 it is about $\mathbf{- 2 . 0}$, characteristic of reactions with silicic minerals (Baker, 1986, and references therein).

\section{Alkalinity}

Alkalinity increases downhole from bottom-water concentrations of about $2.5 \mathrm{mmol} / \mathrm{L}$ to a maximum of about 6.5 to 6.7 $\mathrm{mmol} / \mathrm{L}$ at about $200 \mathrm{mbsf}$, from which depth it decreases to about $4.6 \mathrm{mmol} / \mathrm{L}$ just above basement. The increase in the upper section is a result of regeneration of organic matter and dissolution of carbonates. The deeper inflections may be due to carbonate precipitation reactions within basement consuming alkalinity and calcium. Values of $\mathrm{pH}$ are remarkably constant between 7.6 and 7.8 .

\section{Fluoride, Silica, and Sulfate}

Fluoride decreases downhole from bottom-water concentrations of $70 \mu \mathrm{mol} / \mathrm{L}$ to a minimum of about $24 \mu \mathrm{mol} / \mathrm{L}$ at about $150 \mathrm{mbsf}$, below which it increases slightly. This profile is similar to that observed at all previous Leg 114 sites and requires consumption of fluoride by incorporation into some unidentified fluoride-containing mineral phase, perhaps by sorption onto clays or by precipitation of very small amounts of disseminated carbonate fluorapatite.

Dissolved silica increases downhole from bottom-water concentrations of about $80 \mu \mathrm{mol} / \mathrm{L}$ to a maximum of about 1200 $\mu \mathrm{mol} / \mathrm{L}$ just above basement. The interval adjacent to basement displays much lower silica concentrations of $633 \mu \mathrm{mol} / \mathrm{L}$. This profile requires a downward diffusive flux of dissolved silica by diatom dissolution below $420.7 \mathrm{mbsf}$ and incorporation of this silica into an authigenic silica-containing mineral phase. This horizon corresponds to a change in the siliceous lithology from a dominantly diatom-bearing sediment above 450 mbsf to a dominantly zeolitic, diatom-free sediment below $450 \mathrm{mbsf}$ (Fig. 21). This pattern is similar to the lithologic associations between silica concentrations in pore waters and the presence/absence of diatoms/zeolites observed at Sites 699 and 700 . The simplest explanation is that dissolution of diatoms provides a downward diffusive flux of silica below $400 \mathrm{mbsf}$ that is being incorporated into clinoptilolite precipitating in the $50 \mathrm{~m}$ or so just above basement.

Sulfate displays a slight decrease from bottom-water concentrations of $28 \mathrm{mmol} / \mathrm{L}$ to fairly constant concentrations of 23 to $24 \mathrm{mmol} / \mathrm{L}$ below about $100 \mathrm{mbsf}$. The sediment column is thus suboxic, with very slight microbial sulfate reduction still occurring in the upper $100 \mathrm{~m}$ or so. Organic carbon concentrations at this site are higher than at Sites 699 and 700 but are still generally less than $0.3 \%$ (Table 9), except in the upper $50 \mathrm{~m}$ and in the Bruniopsis mirabilis ooze (146-175 mbsf). In these intervals, 


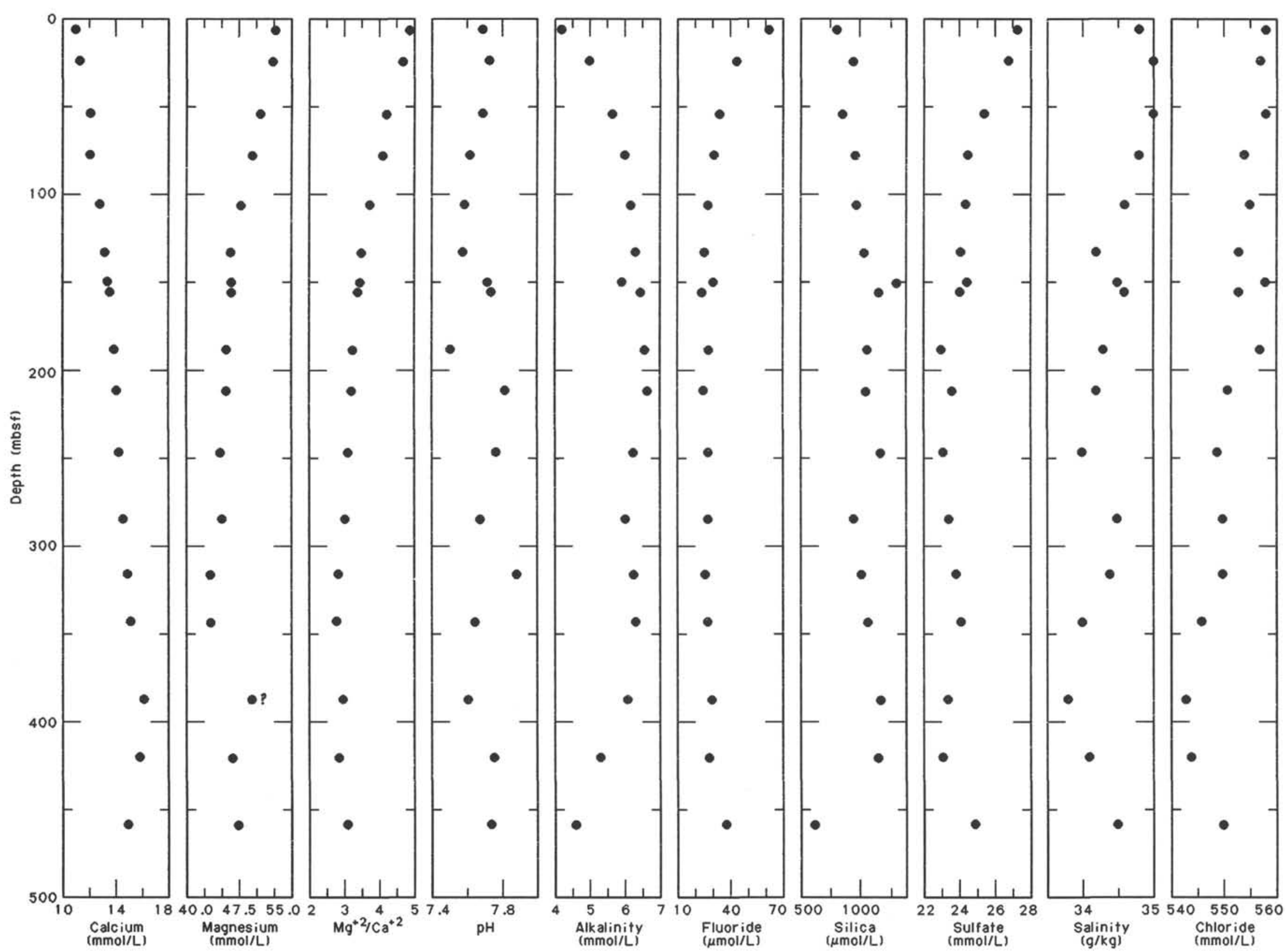

Figure 19. Pore-water calcium, magnesium, $\mathrm{Mg} / \mathrm{Ca}$ ratio, $\mathrm{pH}$, titration alkalinity, fluoride, dissolved silica, sulfate, salinity, and chloride profiles, Site 701 . 


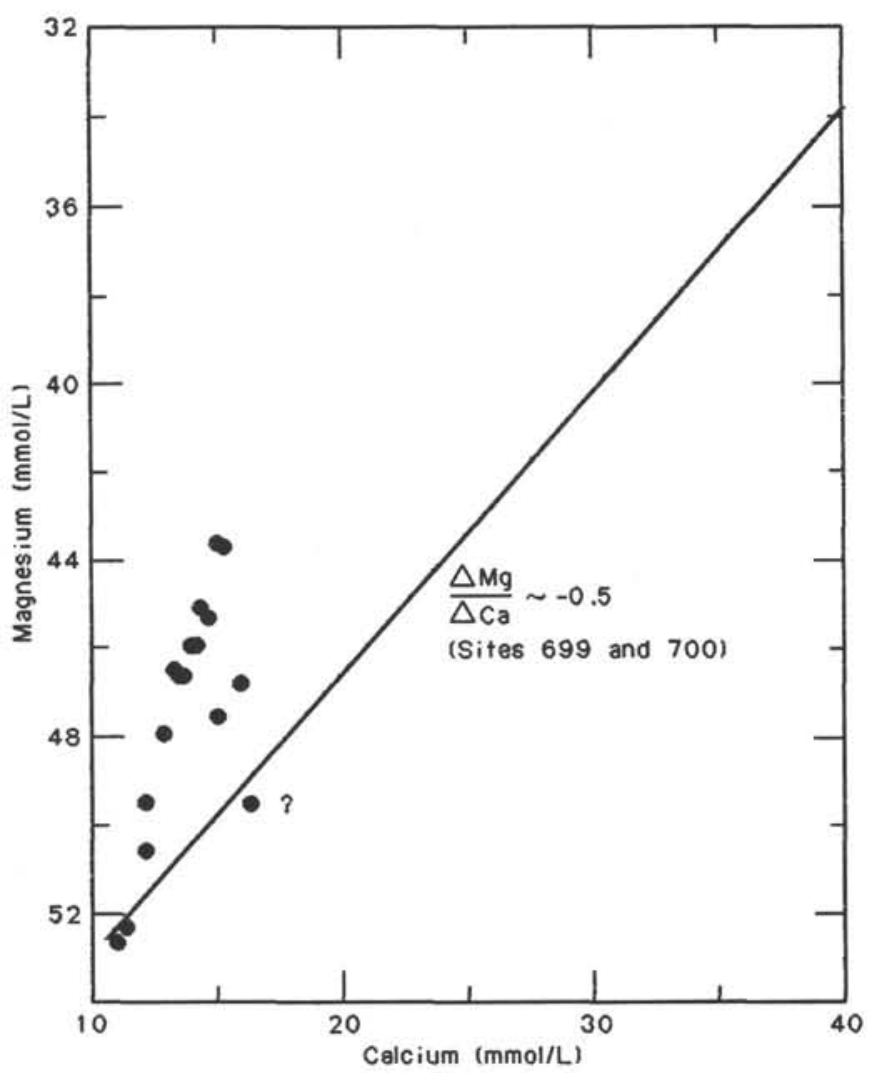

Figure 20. Pore-water calcium vs. magnesium in Holes 701A through 701C. The straight line is the line through the data points from Sites 699 and 700 (see Fig. 22, "Site 700" chapter, this volume). This line has a slope of about $\Delta \mathrm{Mg} / \Delta \mathrm{Ca}=-0.5$ and reflects conservative behavior of calcium and magnesium in the sediment column (no sedimentary reactions) plus diffusive exchange between seawater, a magnesium sink, and a calcium source in the basement via weathering (alteration) of basalts. The data from Site 701 clearly lie above the trend of Sites 699 and 700 and reflect alteration of silicic volcanic material (ash) within the sediment column.

organic carbon concentrations exceed $0.5 \%$ (Fig. 22). Manganese oxide staining of the sediment interval immediately above the Bruniopsis ooze contact suggests that the sediment column was never anoxic after this period (i.e., above this level). Absence of manganese staining of sediments below the Bruniopsis ooze indicates that this laminated interval was deposited under a poorly oxygenated bottom water. The presence of discrete pyrite and pyritized siliceous fragments in this interval suggests in fact that the ooze was deposited under anoxic conditions, possibly extremely organic-carbon-rich and methanorganic.

\section{Volatile Hydrocarbon Gases}

Methane $\left(C_{1}\right)$ and ethane $\left(C_{2}\right)$ are both at very low levels, demonstrating the absence of contemporaneous methanogenesis in the presence of sulfate.

\section{Sedimentary Organic and Inorganic Carbon}

The organic carbon data were discussed in the preceding sulfate section. The calcium carbonate data are presented elsewhere in this volume in relation to lithostratigraphy and physical properties (see "Lithostratigraphy" and "Biostratigraphy" sections, this chapter).

\section{PALEOMAGNETICS}

Three holes were drilled at Site 701 , on Chron $\mathrm{C} 22 \mathrm{~N}$ age (early middle Eocene age) oceanic crust. Hole $701 \mathrm{C}$ provides a

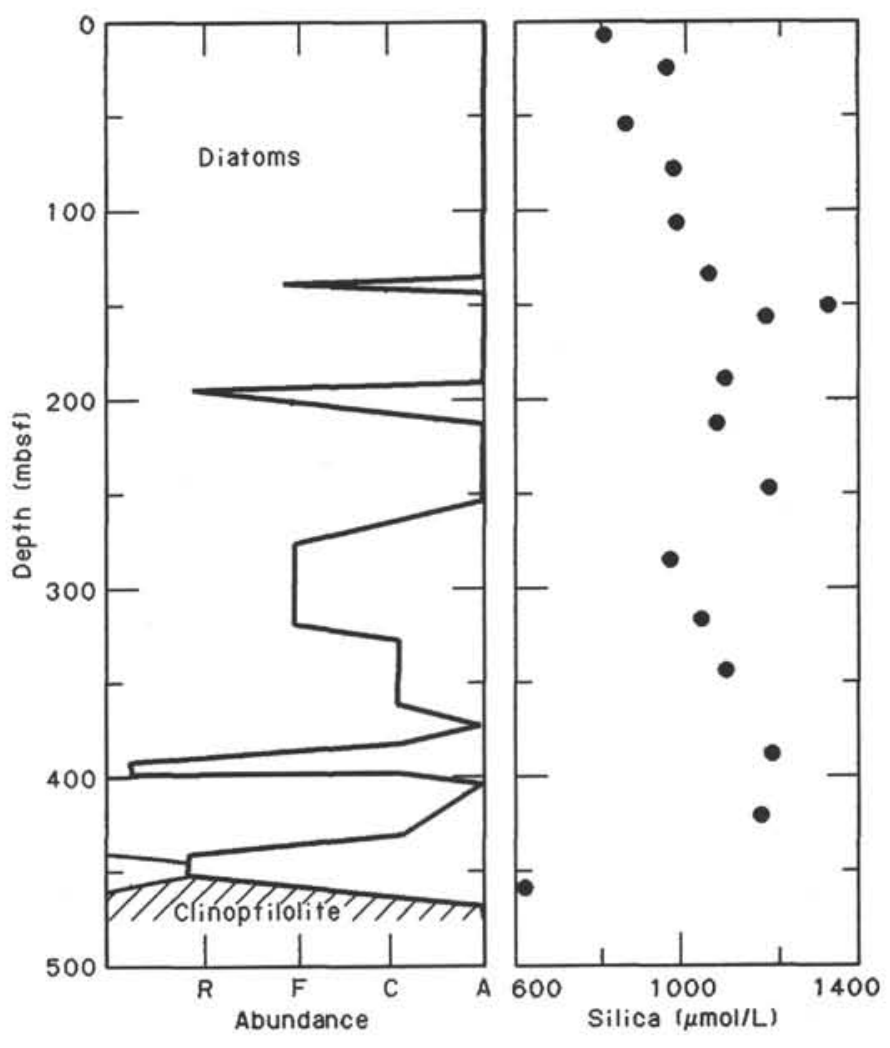

Figure 21. Relative abundance of diatoms and zeolites (clinoptilolite) and the dissolved silica pore-water profile in Hole 701C.

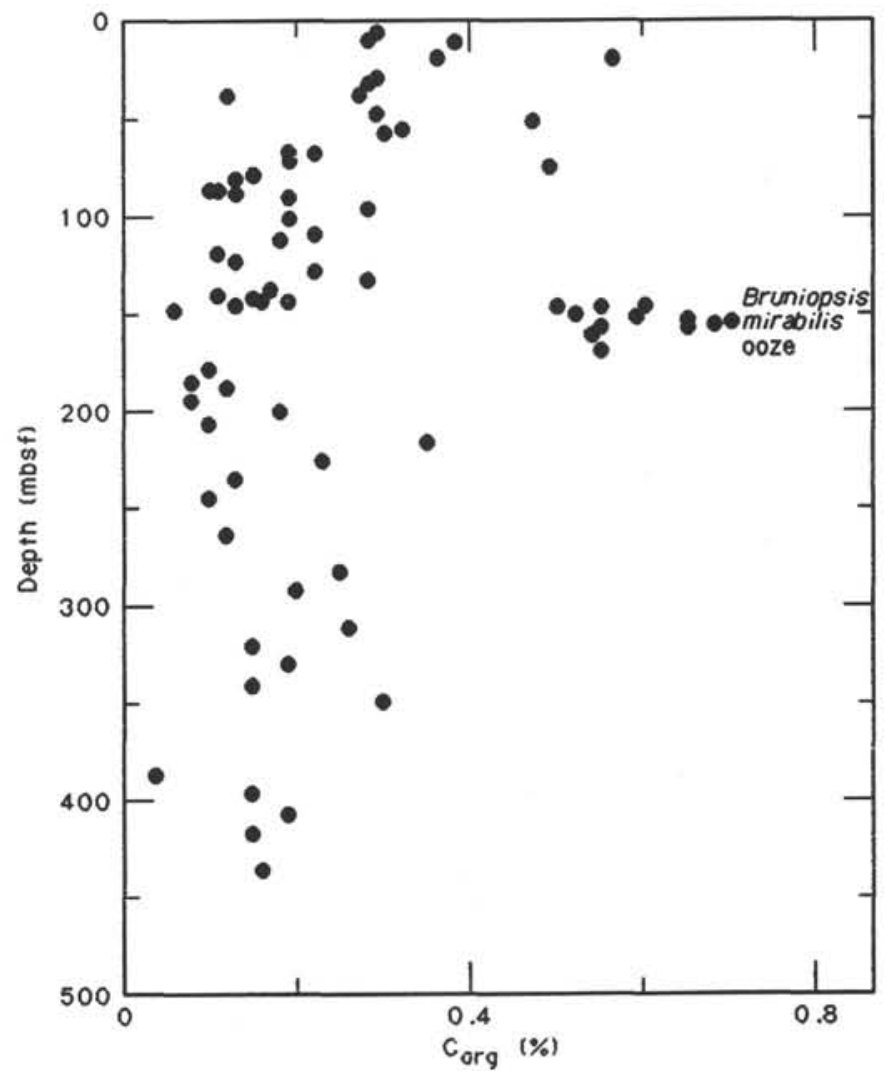

Figure 22. Percent sedimentary organic carbon profile at Site 701. 
Table 8. Volatile hydrocarbon gases (methane and ethane) from Site 701 headspace samples.

\begin{tabular}{|c|c|c|c|}
\hline $\begin{array}{c}\text { Sample } \\
\text { (cm) }\end{array}$ & $\begin{array}{l}\text { Depth } \\
\text { (mbsf) }\end{array}$ & $\underset{(\mathrm{ppm})}{\mathrm{C}_{1}}$ & $\underset{(\mathrm{ppm})}{\mathrm{C}_{2}}$ \\
\hline \multicolumn{4}{|l|}{ Hole 701A: } \\
\hline $1 \mathrm{H}-4,140-145$ & 5.90 & 4.72 & 0.0 \\
\hline $2 \mathrm{H}-4,145-150$ & 14.25 & 5.29 & 0.0 \\
\hline $3 \mathrm{H}-4,115-120$ & 23.45 & 3.58 & 0.0 \\
\hline $4 \mathrm{H}-2,145-150$ & 30.25 & 8.55 & 0.0 \\
\hline SH-5, 145-150 & 44.25 & 11.67 & 0.0 \\
\hline $6 \mathrm{H}-6,0-5$ & 53.80 & 8.75 & 0.0 \\
\hline $7 \mathrm{H}-4,145-150$ & 61.75 & 14.17 & 0.0 \\
\hline $8 \mathrm{H}-4,145-150$ & 71.25 & 6.16 & 0.0 \\
\hline \multicolumn{4}{|l|}{ Hole 701B: } \\
\hline $1 \mathrm{H}-5,115-120$ & 77.15 & 15.53 & 0.0 \\
\hline $2 \mathrm{H}-4,0-5$ & 84.00 & 22.07 & 0.0 \\
\hline $3 \mathrm{H}-5,0-5$ & 95.00 & 15.99 & 0.5 \\
\hline $4 \mathrm{H}-6,145-150$ & 107.45 & 12.43 & 0.0 \\
\hline $5 \mathrm{H}-5,145-150$ & 115.45 & 5.93 & 0.0 \\
\hline $6 \mathrm{H}-3,145-150$ & 121.95 & 6.28 & 0.0 \\
\hline $13 \mathrm{H}-4,0-5$ & 188.50 & 26.42 & 1.0 \\
\hline $14 X-5,0-5$ & 199.50 & 21.30 & 1.1 \\
\hline \multicolumn{4}{|l|}{ Hole $701 \mathrm{C}$ : } \\
\hline $1 \mathrm{H}-2,145-150$ & 2.95 & 4.2 & 0.9 \\
\hline $3 \mathrm{H}-4,145-150$ & 21.75 & 6.8 & 1.1 \\
\hline $5 \mathrm{H}-5,145-150$ & 42.25 & 7.6 & 0.0 \\
\hline $6 \mathrm{H}-5,145-150$ & 51.75 & 8.2 & 0.0 \\
\hline $8 \mathrm{H}-6,145-150$ & 72.25 & 20.8 & 0.0 \\
\hline $10 \mathrm{H}-5,145-150$ & 89.75 & 18.2 & 0.6 \\
\hline $12 \mathrm{H}-2,145-150$ & 104.25 & 16.4 & 0.8 \\
\hline $13 \mathrm{H}-4,145-150$ & 116.75 & 18.1 & 0.0 \\
\hline $15 \mathrm{H}-3,145-150$ & 134.25 & 21.6 & 0.0 \\
\hline $16 \mathrm{H}-5,145-150$ & 146.75 & 10.3 & 0.0 \\
\hline $19 \mathrm{H}-1,145-150$ & 169.25 & 9.5 & 0.0 \\
\hline $20 \mathrm{H}-3,145-150$ & 181.75 & 11.7 & 0.0 \\
\hline $22 \mathrm{H}-6,0-5$ & 203.80 & 22.8 & 0.0 \\
\hline $23 \mathrm{H}-5,0-5$ & 211.80 & 19.5 & 0.0 \\
\hline $25 \mathrm{X}-4,145-150$ & 230.75 & 17.7 & 0.0 \\
\hline $27 X-3,0-5$ & 246.80 & 17.7 & 0.6 \\
\hline $29 X-4,145-150$ & 268.75 & 14.9 & 0.0 \\
\hline $31 X-3,145-150$ & 286.25 & 18.0 & 0.6 \\
\hline $34 X-5,145-150$ & 317.75 & 12.0 & 0.7 \\
\hline $37 X-3,110-115$ & 342.90 & 22.7 & 0.0 \\
\hline $42 X-1,135-140$ & 387.65 & 13.2 & 0.0 \\
\hline $45 \times-4,120-125$ & 420.50 & 9.5 & 0.0 \\
\hline $46 \times-2,145-150$ & 427.25 & 11.4 & 0.0 \\
\hline $50 X-1,145-150$ & 463.75 & 9.2 & 0.3 \\
\hline
\end{tabular}

fairly continuous section that extends from the middle Eocene to the Quaternary. Hole 701A supplements the late Pliocene and Quaternary part of this record, and Hole 701B supplements the late Miocene to late Pliocene part.

\section{Magnetic Susceptibility}

Magnetic susceptibility measurements were made at $10-\mathrm{cm}$ intervals on all cores recovered with the APC at Site 701, using the Bartington pass-through susceptibility meter. Discrete volcanic ash layers occur at various levels throughout the cored interval, and we expected that correlation of the layers would be possible between the holes. We anticipated that the relatively high concentrations of magnetic minerals normally found in volcanic ash would allow the recognition of ash layers in these holes from local high susceptibility values, thereby assisting in correlation. The majority of the ash layers in these holes do produce distinctive susceptibility spikes. However, other locally high susceptibility values, often of greater amplitude, were observed

Table 9. Sedimentary calcium carbonate and organic carbon, Site 701.

\begin{tabular}{|c|c|c|c|}
\hline $\begin{array}{c}\text { Sample } \\
(\mathrm{cm})\end{array}$ & $\begin{array}{l}\text { Depth } \\
\text { (mbsf) }\end{array}$ & $\begin{array}{l}C_{\text {org }} \\
(\%)\end{array}$ & $\begin{array}{c}\mathrm{CaCO} \\
(\%)\end{array}$ \\
\hline \multicolumn{4}{|l|}{ Hole 701A: } \\
\hline $1 \mathrm{H}-4,100-102$ & 5.50 & 0.29 & 0.42 \\
\hline $1 \mathrm{H}-5,100-102$ & 7.00 & & 0.25 \\
\hline $1 \mathrm{H}-6,60-62$ & 8.10 & & 0.17 \\
\hline $2 \mathrm{H}-1,100-102$ & 9.30 & 0.28 & 0.17 \\
\hline $2 \mathrm{H}-2,100-102$ & 10.80 & & 0.08 \\
\hline $2 \mathrm{H}-3,100-102$ & 12.30 & & 0.25 \\
\hline $2 \mathrm{H}-4,100-102$ & 13.80 & & 0.08 \\
\hline $2 \mathrm{H}-5,100-102$ & 15.30 & & 0.08 \\
\hline $2 \mathrm{H}-6,100-102$ & 16.80 & & 0.08 \\
\hline $3 \mathrm{H}-1,100-102$ & 18.80 & 0.56 & 0.08 \\
\hline $3 \mathrm{H}-3,100-102$ & 21.80 & & 0.75 \\
\hline $3 \mathrm{H}-5,100-102$ & 24.80 & & 0.58 \\
\hline $4 \mathrm{H}-3,100-102$ & 31.30 & 0.28 & 4.25 \\
\hline $5 \mathrm{H}-1,100-102$ & 37.80 & 0.12 & 10.76 \\
\hline $5 \mathrm{H}-2,100-102$ & 39.30 & & 9.34 \\
\hline $5 \mathrm{H}-3,100-102$ & 40.80 & & 0.00 \\
\hline $5 \mathrm{H}-4,100-102$ & 42.30 & & 0.25 \\
\hline $5 \mathrm{H}-5,100-102$ & 43.80 & & 0.17 \\
\hline $5 \mathrm{H}-6,100-102$ & 45.30 & & 0.17 \\
\hline $6 \mathrm{H}-3,100-102$ & 50.30 & 0.47 & 0.17 \\
\hline $6 \mathrm{H}-4,100-102$ & 51.80 & & 0.25 \\
\hline $6 \mathrm{H}-5,100-102$ & 53.30 & & 0.17 \\
\hline $6 \mathrm{H}-6,100-102$ & 54.80 & & 0.33 \\
\hline $7 \mathrm{H}-1,100-102$ & 56.80 & 0.30 & 0.17 \\
\hline $7 \mathrm{H}-2,100-102$ & 58.30 & & 0.17 \\
\hline $7 \mathrm{H}-3,100-102$ & 59.80 & & 0.25 \\
\hline $7 \mathrm{H}-4,100-102$ & 61.30 & & 0.25 \\
\hline $8 \mathrm{H}-1,100-102$ & 66.30 & 0.19 & 0.25 \\
\hline $8 \mathrm{H}-2,100-102$ & 67.80 & & 0.08 \\
\hline $8 \mathrm{H}-3,100-102$ & 69.30 & & 0.25 \\
\hline $8 \mathrm{H}-4,100-102$ & 70.80 & & 0.17 \\
\hline $8 \mathrm{H}-5,100-102$ & 72.30 & & 0.25 \\
\hline $8 \mathrm{H}-6,100-102$ & 73.80 & & 0.17 \\
\hline
\end{tabular}

Hole 701B:

$\begin{array}{lrll}1 \mathrm{H}-1,100-102 & 71.00 & 0.19 & 0.00 \\ 1 \mathrm{H}-2,100-102 & 72.50 & & 0.00 \\ 1 \mathrm{H}-3,100-102 & 74.00 & & 0.00 \\ 1 \mathrm{H}-4,100-102 & 75.50 & & 0.00 \\ 1 \mathrm{H}-5,100-102 & 77.00 & & 0.00 \\ 2 \mathrm{H}-1,100-102 & 80.50 & 0.13 & 0.00 \\ 2 \mathrm{H}-2,100-102 & 82.00 & & 0.00 \\ 2 \mathrm{H}-3,100-102 & 83.50 & & 0.00 \\ 2 \mathrm{H}-4,100-102 & 85.00 & & 0.00 \\ 3 \mathrm{H}-1,100-102 & 90.00 & 0.19 & 0.00 \\ 3 \mathrm{H}-2,100-102 & 91.50 & & 0.00 \\ 3 \mathrm{H}-3,100-102 & 93.00 & & 0.00 \\ 3 \mathrm{H}-4,100-102 & 94.50 & & 0.00 \\ 3 \mathrm{H}-5,100-102 & 96.00 & & 0.00 \\ 4 \mathrm{H}-2,100-102 & 101.00 & 0.19 & 0.00 \\ 4 \mathrm{H}-3,100-102 & 102.50 & & 0.00 \\ 4 \mathrm{H}-4,100-102 & 104.00 & & 0.00 \\ 4 \mathrm{H}-5,100-102 & 105.50 & & 0.00 \\ 4 \mathrm{H}-6,100-102 & 107.00 & & 0.00 \\ 5 \mathrm{H}-1,100-102 & 109.00 & 0.22 & 0.00 \\ 5 \mathrm{H}-2,100-102 & 110.50 & & 0.00 \\ 5 \mathrm{H}-3,100-102 & 112.00 & & 0.00 \\ 5 \mathrm{H}-4,100-102 & 113.50 & & 0.00 \\ 5 \mathrm{H}-5,100-102 & 115.00 & & 0.00 \\ 5 \mathrm{H}-6,100-102 & 116.50 & & 0.00 \\ 6 \mathrm{H}-1,110-112 & 118.60 & 0.11 & 0.00 \\ 6 \mathrm{H}-2,98-100 & 119.98 & & 0.00 \\ 6 \mathrm{H}-3,26-27 & 120.76 & & 0.00 \\ 7 \mathrm{H}-1,101-103 & 128.01 & 0.22 & 0.00 \\ 8 \mathrm{H}-1,98-100 & 137.48 & 0.17 & 0.00 \\ 8 \mathrm{H}-5,100-102 & 143.50 & 0.19 & 0.00 \\ 10 \mathrm{H}-1,100-102 & 156.50 & 0.55 & 0.83 \\ 13 \mathrm{H}-1,100-102 & 185.00 & 0.08 & 0.83 \\ 14 \mathrm{H}-1,100-102 & 194.50 & 0.08 & 0.83\end{array}$


Table 9 (continued).

\begin{tabular}{|c|c|c|c|}
\hline $\begin{array}{c}\text { Sample } \\
\text { (cm) }\end{array}$ & $\begin{array}{l}\text { Depth } \\
\text { (mbsf) }\end{array}$ & $\begin{array}{l}C_{\text {org }} \\
(\%)\end{array}$ & $\begin{array}{c}\mathrm{CaCO}_{3} \\
(\%)\end{array}$ \\
\hline \multicolumn{4}{|l|}{ Hole 701C: } \\
\hline $2 \mathrm{H}-3,130-132$ & 10.60 & 0.38 & 0.08 \\
\hline $3 \mathrm{H}-2,100-102$ & 18.30 & 0.36 & 0.17 \\
\hline $4 \mathrm{H}-2,100-102$ & 27.80 & 0.29 & 0.17 \\
\hline $5 \mathrm{H}-2,101-103$ & 37.31 & 0.27 & 10.76 \\
\hline $6 \mathrm{H}-2,80-82$ & 46.60 & 0.29 & 0.08 \\
\hline $7 \mathrm{H}-1,100-102$ & 54.80 & 0.32 & 0.17 \\
\hline $8 \mathrm{H}-3,100-102$ & 67.30 & 0.22 & 0.17 \\
\hline $9 \mathrm{H}-1,120-122$ & 74.00 & 0.49 & 0.08 \\
\hline $9 \mathrm{H}-4,100-102$ & 78.30 & 0.15 & 0.50 \\
\hline $10 \mathrm{H}-2,100-102$ & 86.30 & 0.10 & 0.17 \\
\hline $10 \mathrm{H}-3,100-102$ & 86.30 & 0.11 & 0.42 \\
\hline $10 \mathrm{H}-4,100-102$ & 87.80 & 0.13 & 0.17 \\
\hline $11 \mathrm{H}-3,100-102$ & 95.80 & 0.28 & 0.17 \\
\hline $13 \mathrm{H}-1,100-102$ & 111.80 & 0.18 & 0.17 \\
\hline $14 \mathrm{H}-2,100-102$ & 122.80 & 0.13 & 0.17 \\
\hline $15 \mathrm{H}-2,100-102$ & 132.30 & 0.28 & 0.58 \\
\hline $16 \mathrm{H}-1,100-102$ & 140.30 & 0.11 & 0.17 \\
\hline $16 \mathrm{H}-2,101-103$ & 141.81 & 0.15 & 0.08 \\
\hline $16 \mathrm{H}-3,101-103$ & 143.31 & 0.16 & 0.17 \\
\hline $16 \mathrm{H}-4,130-131$ & 145.10 & 0.13 & 0.25 \\
\hline $16 \mathrm{H}-5,10-11$ & 145.40 & 0.13 & 0.25 \\
\hline $16 \mathrm{H}-5,30-31$ & 145.60 & 0.60 & 0.17 \\
\hline $16 \mathrm{H}-5,60-61$ & 145.90 & 0.50 & 0.25 \\
\hline $16 \mathrm{H}-5,120-121$ & 146.50 & 0.55 & 0.33 \\
\hline $16 \mathrm{H}-6,100-102$ & 147.80 & 0.06 & 0.08 \\
\hline $17 \mathrm{H}-1,100-102$ & 149.80 & 0.52 & 0.25 \\
\hline $17 \mathrm{H}-2,101-103$ & 151.31 & 0.59 & 0.50 \\
\hline $17 \mathrm{H}-3,80-82$ & 152.60 & 0.65 & 0.08 \\
\hline $17 \mathrm{H}-4,99-101$ & 153.77 & 0.70 & 0.33 \\
\hline $17 \mathrm{H}-5,99-101$ & 155.27 & 0.68 & 0.33 \\
\hline $17 \mathrm{H}-6,99-101$ & 156.77 & 0.65 & 0.42 \\
\hline $18 \mathrm{H}-2,89-91$ & 160.69 & 0.54 & 0.25 \\
\hline $19 \mathrm{H}-1,99-101$ & 168.79 & 0.55 & 0.17 \\
\hline $20 \mathrm{H}-1,98-100$ & 178.28 & 0.10 & 0.17 \\
\hline $21 \mathrm{H}-1,98-100$ & 187.78 & 0.12 & 0.17 \\
\hline $22 \mathrm{H}-3,100-102$ & 200.30 & 0.18 & 0.17 \\
\hline $23 \mathrm{H}-1,100-102$ & 206.80 & 0.10 & 0.08 \\
\hline $24 \mathrm{H}-1,100-102$ & 216.30 & 0.35 & 0.08 \\
\hline $25 \mathrm{X}-1,100-102$ & 225.80 & 0.23 & 0.08 \\
\hline $26 \mathrm{X}-1,100-102$ & 235.30 & 0.13 & 3.25 \\
\hline $27 \mathrm{X}-1,100-102$ & 244.80 & 0.10 & 0.08 \\
\hline $29 X-1,100-102$ & 263.80 & 0.12 & 0.17 \\
\hline $31 X-1,100-102$ & 282.80 & 0.25 & 18.35 \\
\hline $31 X-4,100-102$ & 287.30 & & 0.42 \\
\hline $32 X-1,100-102$ & 292.30 & 0.20 & 0.08 \\
\hline $34 X-1,98-100$ & 311.28 & 0.26 & 0.08 \\
\hline $35 X-1,100-102$ & 320.80 & 0.15 & 0.42 \\
\hline $36 \times-1,100-102$ & 330.30 & 0.19 & 0.00 \\
\hline $37 \times-2,90-92$ & 341.20 & 0.15 & 0.17 \\
\hline $38 X-1,100-102$ & 349.30 & 0.30 & 1.00 \\
\hline $42 X-1,100-102$ & 387.30 & 0.04 & 0.17 \\
\hline $43 X-1,100-102$ & 396.80 & 0.15 & 0.17 \\
\hline $43 \times-2,100-102$ & 398.30 & & 7.17 \\
\hline $43 X-3,100-102$ & 399.80 & & 4.42 \\
\hline $43 X-4,100-102$ & 401.30 & & 1.33 \\
\hline $43 X-5,100-102$ & 402.80 & & 28.86 \\
\hline $43 X-6,100-102$ & 404.30 & & 1.58 \\
\hline $44 X-2,100-102$ & 407.80 & 0.19 & 20.60 \\
\hline $44 \mathrm{X}-3,100-102$ & 409.30 & & 23.27 \\
\hline $44 X-4,100-102$ & 410.80 & & 40.95 \\
\hline $44 X-5,100-102$ & 412.30 & & 46.70 \\
\hline $44 X-6,100-102$ & 413.80 & & 5.25 \\
\hline $45 \times-2,110-112$ & 417.40 & 0.15 & 0.17 \\
\hline $45 X-4,100-102$ & 420.30 & & 9.76 \\
\hline $47 X-2,102-104$ & 436.32 & 0.16 & 14.43 \\
\hline $47 X-3,102-104$ & 437.82 & & 4.59 \\
\hline $47 X-6,102-104$ & 442.32 & & 13.09 \\
\hline $49 X-2,101-103$ & 455.31 & -0.07 & 69.06 \\
\hline $49 X-3,74-76$ & 456.54 & & 82.07 \\
\hline $49 X-4,100-102$ & 458.30 & & 75.23 \\
\hline $49 \times-5,67-69$ & 459.47 & & 85.15 \\
\hline $49 X-6,11-13$ & 460.41 & & 89.07 \\
\hline
\end{tabular}

at the top of each core, particularly in Holes 701A and 701B. These are caused by concentrations of basaltic pebbles, manganese nodules, and other clasts at the core tops as a result of downhole contamination. Consequently, it was necessary to exclude the susceptibility data for the uppermost 10 to $30 \mathrm{~cm}$ of each core from the downhole plots before susceptibility signals from the ash layers could be reliably identified. The edited plots are shown in Figure 23. The positions of ash layers identified from visual inspection of the cores and/or core photographs are shown in the left-hand column of this figure. The more prominent ash layers are numbered sequentially downhole and labeled according to the hole letter (A, B, or C).

Inspection of these plots reveals that the majority of the ash layers are characterized by local high susceptibility values. A tentative correlation of some of the more distinctive ash layers is shown in Figure 24.

Uncertainties in the true depths of individual ash layers in the three holes arise from (1) difficulty in locating the true depth of the core barrel beneath the seafloor at the time the core is taken, because of the heave of the vessel (a particularly heavy swell was experienced during drilling at this site) and (2) difficulty in correctly positioning the recovered sediment within the core barrel (it is normally assumed that the recovered sediment comes from the top of the cored interval; however, this is not necessarily the case, especially if sediment "flow-in" has occurred, as was observed in a number of core sections from this site).

Within the estimated limits of uncertainty, however, most of the more conspicuous ash layers appear to have possible counterparts in the other holes. The occasional absence of a counterpart probably can be explained by drilling disturbance or incomplete recovery.

\section{Directions of Magnetization}

The magnetization of the majority of archive core halves spanning the middle Miocene to Quaternary interval in all three holes was measured using the pass-through cryogenic magnetometer. Measurements were made before and after alternating field (AF) demagnetization in fields of 5 and/or $9 \mathrm{mT}$ (the limit of the shipboard pass-through demagnetizer).

Discrete samples, representative of each of the major polarity zones, were subjected to incremental $\mathrm{AF}$ demagnetization at 5 -mT intervals up to a maximum field in the range 80 to $90 \mathrm{mT}$. Examples of demagnetization behavior of samples exhibiting normal and reverse polarity directions are shown in Figure 25. In many of the samples analyzed, demagnetization at $10 \mathrm{mT}$ appears to be adequate to provide a reliable definition of the stable characteristic magnetization. However, treatment at $20 \mathrm{mT}$ is required for other samples. For this reason, only the results from measurements of discrete samples are shown in Figure 26. All discrete samples were progressively demagnetized at $10 \mathrm{mT}$ increments up to at least $30 \mathrm{mT}$, and the resulting determinations after treatment at $20 \mathrm{mT}$ are plotted as solid circles in Figure 26.

\section{Polarity Stratigraphy}

The magnetic polarity zonations identified in Holes 701A through $701 \mathrm{C}$ are shown in Figure 26. There is general conformity between the succession of normal and reverse polarity magnetozones in the three holes. Small depth discrepancies of up to $1.5 \mathrm{~m}$ exist between the positions of magnetozone boundaries in different holes, but in all cases these discrepancies are within the range of uncertainty of the true position of the recovered sediment within the core. The three sets of data are combined into a composite polarity reversal sequence in the right-hand çolumn 


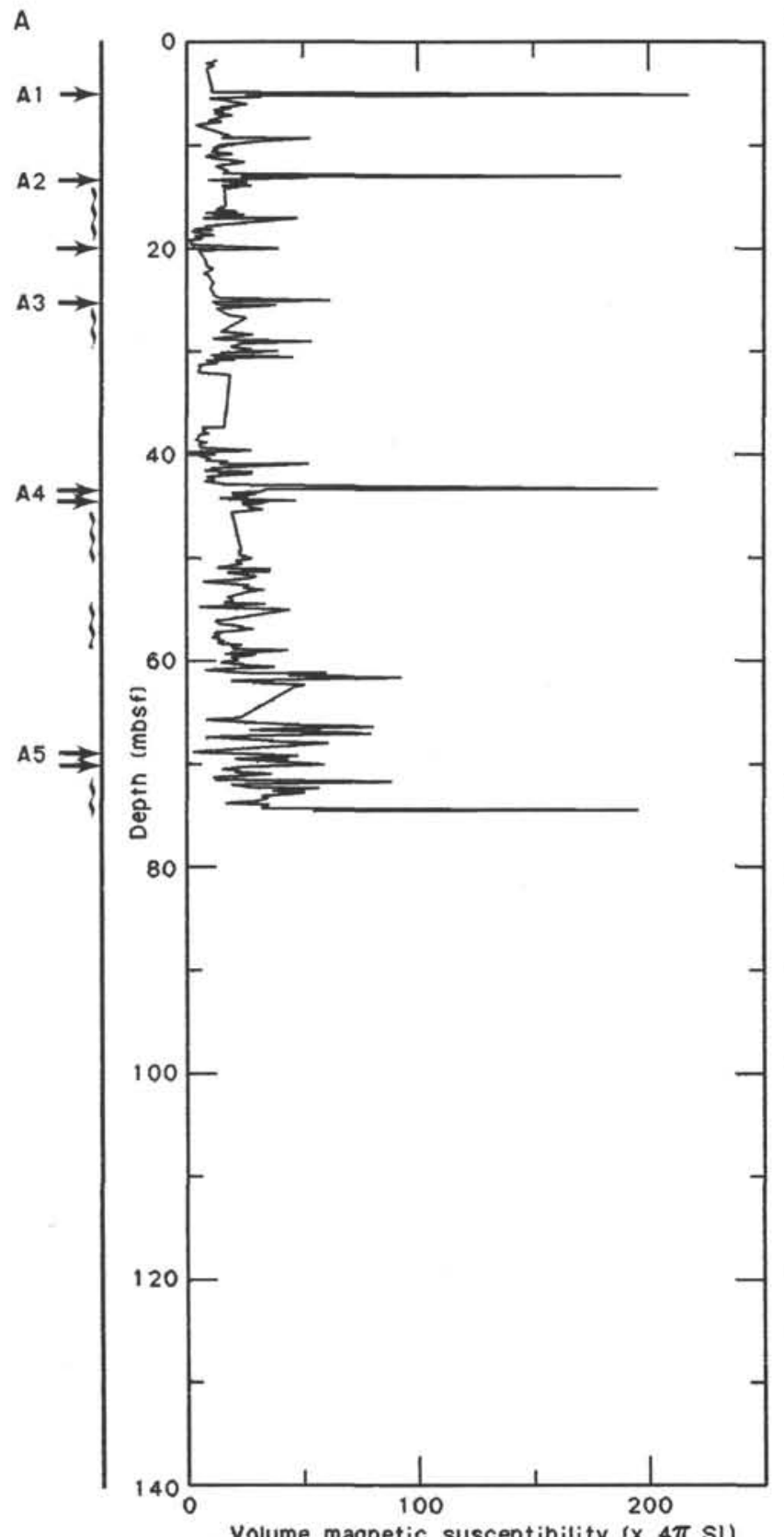

B

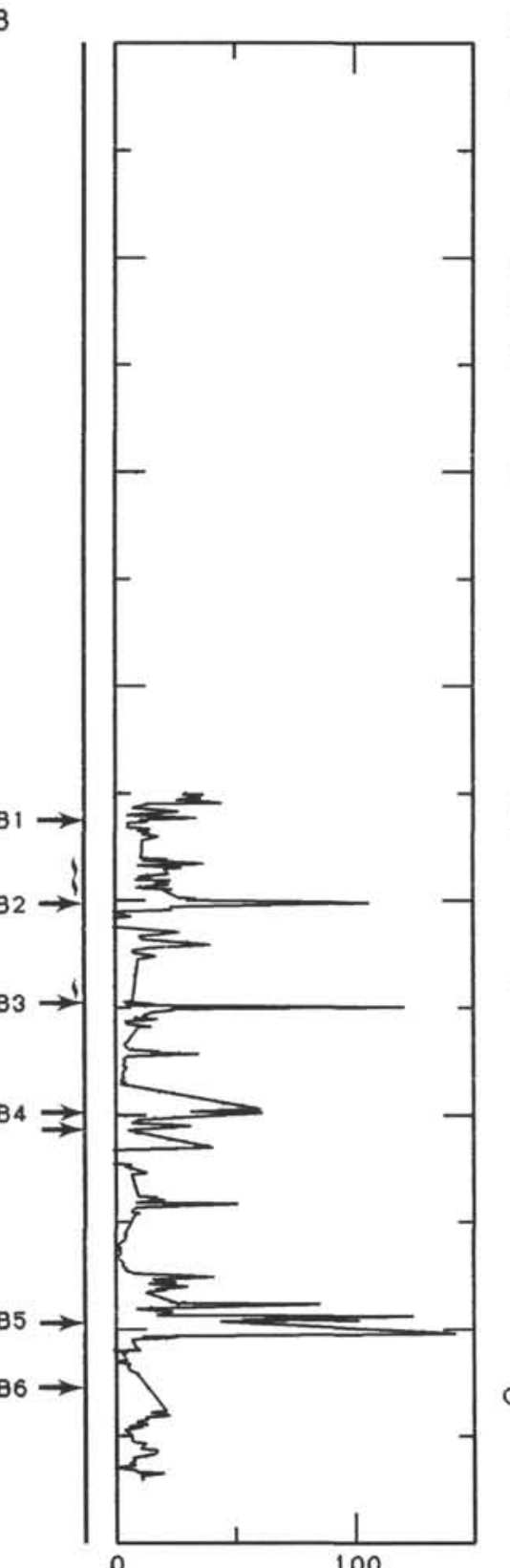

volume magnetic susceptibility (x $4 \pi$ SI)
C

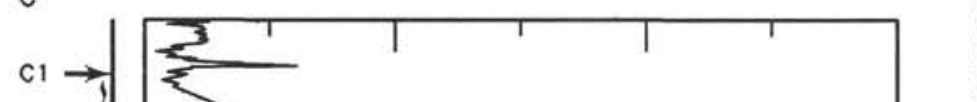

Figure 23. Variation of magnetic susceptibility with depth in Holes 701A through 701C. Positions of ash layers are indicated by arrows at left of diagram. The more conspicuous ash layers are numbered sequentially downhole. The prefix A, B, or C refers to the hole letter. Intervals of drilling disturbance (particularly flow-in) are indicated by wavy lines down this axis. The majority of ash layers are marked by susceptibility peaks, as a result of their relatively high magnetite content. 

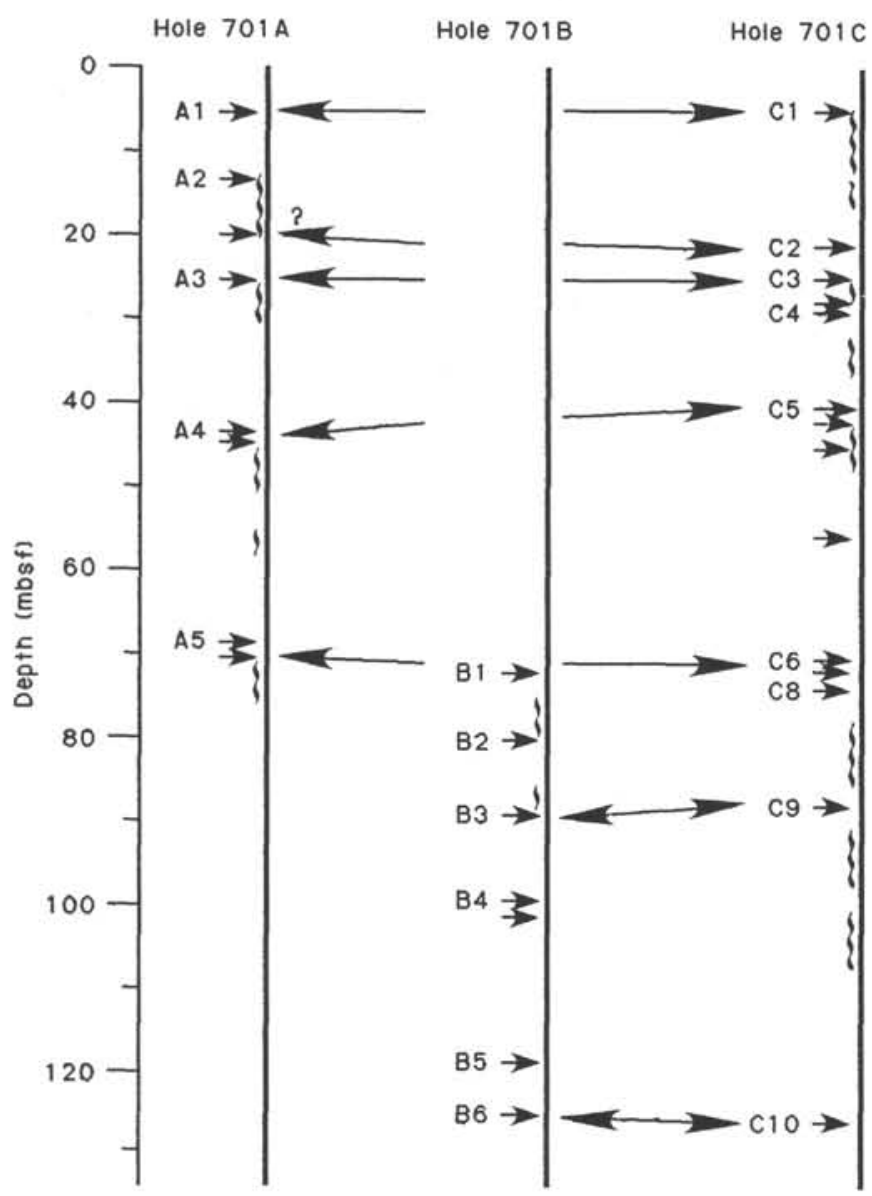

Figure 24. Tentative correlation between ash layers (and associated susceptibility peaks) in Holes 701A through 701C.
A

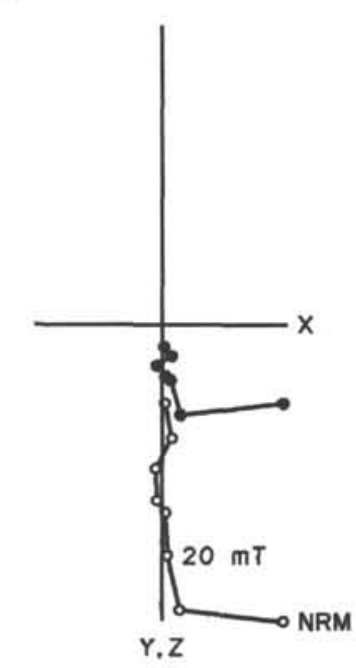

Sample $114-701 \mathrm{~A}-5 \mathrm{H}-3$. $87-89 \mathrm{~cm}$
B

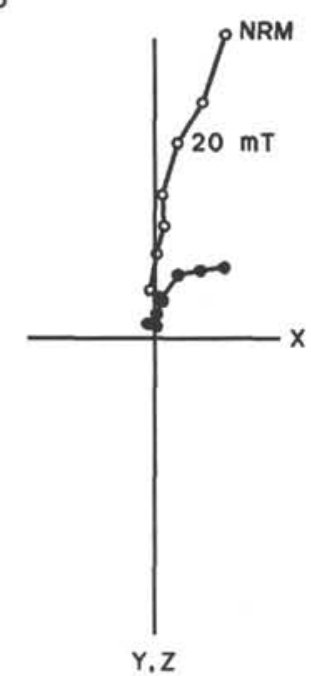

Sample $114-7018-8 \mathrm{H}-3$.
Figure 25. Results of progressive AF demagnetization of two samples yielding reverse (A) and normal (B) polarity magnetizations plotted as orthogonal, vector end-point diagrams. Open symbols represent projection onto the vertical (XZ) plane. Solid symbols represent projection onto the horizontal (XY) plane. Intensities are normalized to natural remanent magnetization values. of Figure 26. The depths below seafloor in this sequence refer to Hole 701C.

The upper $40 \mathrm{~m}$ in Holes 701A and 701C is of Pleistocene age (see "Biostratigraphy" section). Consequently, the uppermost normal polarity magnetozone identified in these two holes must represent the Brunhes Chron. The Brunhes/Matuyama boundary $(0.73 \mathrm{Ma}$; Berggren et al., 1985$)$ is thereby established at $24 \mathrm{mbsf}$ in Hole $701 \mathrm{C}$. The underlying dominantly reverse polarity magnetozone is of late Pliocene-early Pleistocene age; thus, the depth range 67 to 21 mbsf must represent the Matuyama Chron.

The early Pliocene/late Pliocene boundary was correlated with the older end of the Gauss normal chron on the GPTS of Berggren et al. (1985). From the position of this epoch boundary within Cores 114-701B-2H and 114-701C-9H (see "Biostratigraphy" section), the dominantly normal polarity magnetozone within the depth range 67 to $72 \mathrm{mbsf}$ represents the Gauss Chron. Its relatively short thickness can be attributed to the possible presence of a stratigraphic hiatus within Core 114$701 \mathrm{C}-8 \mathrm{H}$ (see "Biostratigraphy" section). The underlying dominantly reverse polarity magnetozone of early Pliocene age, in the depth range 77.5 to 131.5 mbsf, thus represents the Gilbert Chron. The four Gilbert Subchrons are each represented in the central part of this magnetozone.

Finally, the normal polarity magnetozone identified between 135 and 145 mbsf can be correlated with Chron C3AN (formerly chron 5), the younger end of which defines the Miocene/ Pliocene boundary (Berggren et al., 1985).

The composite magnetostratigraphy derived from Holes 701A through $701 \mathrm{C}$ represents an almost complete record of geomagnetic polarity reversal history over the past $5 \mathrm{Ma}$.

\section{PHYSICAL PROPERTIES}

The objective of physical-property measurements at Site 701 was to study the correlation between physical-property variations and changes in the character of the sediments with depth below seafloor. As at Site 699, a study of the impact of hiatuses at Site 701 was conducted, because episodes of nondeposition or removal of sediments may be reflected in physical-property variations.

The physical-property measurement methods are described in the "Explanatory Notes" chapter. Four sets of measurements were obtained on selected samples of relatively undisturbed sediment sections cored with the APC and XCB systems: (1) index properties (wet-bulk density, dry-bulk density, porosity, water content, and grain density), (2) compressional-wave ( $P$-wave) velocity, (3) vane shear strength, and (4) thermal conductivity. The carbonate content (from "Geochemistry" section) is presented for comparison with the physical-property results. All of the data are unfiltered for any bad data points.

\section{Physical-Property Summary and Lithostratigraphic Correlation}

Index properties, carbonate content, $P$-wave velocity, thermal conductivity, and shear strength data are listed in Tables 10 through 14. The downcore profiles of wet-bulk density, porosity, water content, grain density, carbonate content, $P$-wave velocity, thermal conductivity, and shear strength are illustrated in Figure 27 . The physical-property variations correlate closely with the lithostratigraphic changes observed in the cores (see "Lithostratigraphy" section) and are summarized as follows:

Lithostratigraphic Unit I (0-74.8 mbsf, Hole 701A; 0-203 mbsf, Hole 701B; 0-243.8 mbsf, Hole 701C; middle Miocene to Quaternary) is primarily a diatom ooze with a sand/gravel subunit (IC) interrupting the sequence. The entire unit may be characterized as having essentially no carbonate. The differ- 

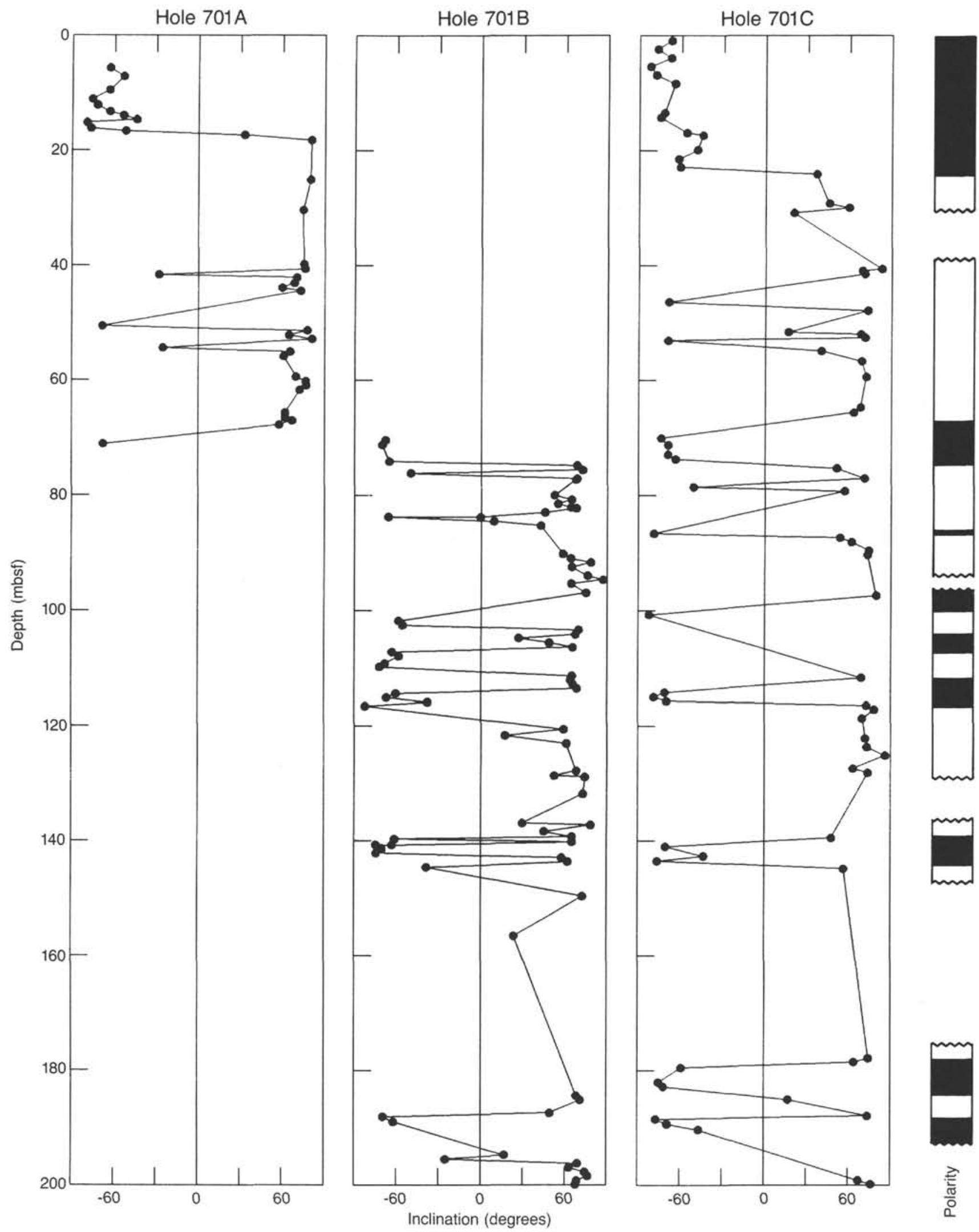

Figure 26. Results of measurements of discrete samples plotted as inclination vs. depth below seafloor from Holes 701A through 701C. Also shown is the composite polarity log constructed using the data from all three holes. 
Table 10. Index properties, Site 701

\begin{tabular}{ccccccc}
\hline & & & \multicolumn{3}{c}{ Densities } \\
\cline { 5 - 7 } & & & & Water \\
$(\mathrm{cm})$ & $\begin{array}{c}\text { Depth } \\
(\text { mbsf })\end{array}$ & $\begin{array}{c}\text { content } \\
(\%)\end{array}$ & $\begin{array}{c}\text { Porosity } \\
(\%)\end{array}$ & $\begin{array}{c}\text { Wet } \\
\text { bulk } \\
\left(\mathrm{g} / \mathrm{cm}^{3}\right)\end{array}$ & $\begin{array}{c}\text { Dry } \\
\text { bulk } \\
\left(\mathrm{g} / \mathrm{cm}^{3}\right)\end{array}$ & $\begin{array}{c}\text { Grain } \\
\left(\mathrm{g} / \mathrm{cm}^{3}\right)\end{array}$
\end{tabular}

Hole 701A:

$\begin{array}{llllll}1 \mathrm{H}-4,58-60 & 5.08 & 28.73 & 51.88 & 1.85 & 1.32\end{array}$

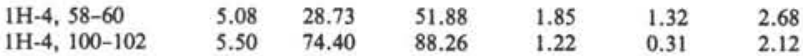

$1 \mathrm{H}-5,100-102 \quad 7.00 \quad 68.30-84.59$

$\begin{array}{lllllll}2 \mathrm{H}-3,100-102 & 10.80 & 73.08 & 87.99 & 1.23 & 0.33 & 2.29\end{array}$

$\begin{array}{lll}2 \mathrm{H}-4,17-18 & 12.97 & 26.73\end{array}$

$2 \mathrm{H}-4,100-102 \quad 13.80 \quad 71.99$

$2 \mathrm{H}-5,100-102 \quad 15.30 \quad 68.51$

$2 \mathrm{H}-6,100-102 \quad 16.80 \quad 59.37$

$\begin{array}{lll}3 \mathrm{H}-1,100-102 & 18.80 & 76.77\end{array}$

$3 \mathrm{H}-3,100-102 \quad 21.80 \quad 71.28$

$3 \mathrm{H}-5,100-102$

$4 \mathrm{H}-3,100-102$

$5 \mathrm{H}-1,100-102$

$5 \mathrm{H}-2,100-102$

$5 \mathrm{H}-3,100-102$

$5 \mathrm{H}-4,100-102$

$5 \mathrm{H}-5,100-102$

5H-6, 100-102

$6 \mathrm{H}-3,100-102$

$6 \mathrm{H}-4,100-102$

$6 \mathrm{H}-5,100-102$
$6 \mathrm{H}-6,100-102$

$6 \mathrm{H}-6,100-102$
$7 \mathrm{H}-1,100-102$

$7 \mathrm{H}-2,100-102$

$7 \mathrm{H}-3,100-102$

$7 \mathrm{H}-4,100-102$

$8 \mathrm{H}-1,100-102$

$8 \mathrm{H}-2,100-102$

$8 \mathrm{H}-3,100-102$

$8 \mathrm{H}-4,100-102$

$8 \mathrm{H}-5,100-102$

8 H-6, 100-102

$24.80 \quad 69.44$

$\begin{array}{ll}31.30 & 69.21 \\ 37.80 & 64.99\end{array}$

$\begin{array}{ll}37.80 & 64.99 \\ 39.30 & 67.24\end{array}$

$40.80 \quad 61.01$

$42.30 \quad 60.92$

$\begin{array}{ll}43.38 & 27.49 \\ 43.80 & 55.82\end{array}$

$\begin{array}{ll}43.80 & 55.82 \\ 45.30 & 53.59\end{array}$

\begin{tabular}{l}
$50.30 \quad 61.66$ \\
\hline
\end{tabular}

$\begin{array}{ll}51.80 & 57.49\end{array}$

$\begin{array}{ll}53.30 & 58.55 \\ 54.80 & 70.04\end{array}$

$\begin{array}{ll}54.80 & 70.04 \\ 56.80 & 62.24\end{array}$

$58.30 \quad 64.44$
5.80

$59.80 \quad 63.60$

$\begin{array}{ll}61.30 & 61.46 \\ 66.30 & 59.09\end{array}$

$\begin{array}{ll}66.30 & 59.09 \\ 67.80 & 56.12\end{array}$

$69.30 \quad 56.99$

$70.35 \quad 37.42$

$\begin{array}{ll}70.80 & 57.04 \\ 72.30 & 59.91\end{array}$

$\begin{array}{ll}73.80 & 57.91\end{array}$

$\begin{array}{llll}.35 & 1.97 & 1.44 & 2.71\end{array}$

$\begin{array}{llll}86.47 & 1.23 & 0.34 & 2.44\end{array}$

$\begin{array}{llll}78.16 & 1.26 & 0.40 & 2.33 \\ 91.53 & 1.22 & 0.55 & 2.50\end{array}$

$\begin{array}{llll}91.53 & 1.22 & 0.28 & 2.00\end{array}$

$\begin{array}{llll}86.08 & 1.24 & 0.36 & 2.16\end{array}$

$\begin{array}{llll}84.72 & 1.25 & 0.38 & 2.18 \\ 85.63 & 1.27 & 0.39 & 2.53\end{array}$

$\begin{array}{llll}82.31 & 1.30 & 0.45 & 2.27\end{array}$

$\begin{array}{llll}84.99 & 1.30 & 0.42 & 2.22\end{array}$

$\begin{array}{llll}79.57 & 1.34 & 0.52 & 2.41\end{array}$

$\begin{array}{llll}58.13 & 2.17 & 1.57 & 2.72\end{array}$

$\begin{array}{llll}77.42 & 1.42 & 0.63 & 2.69 \\ 75.90 & 1.45 & 0.67 & 2.62\end{array}$

$\begin{array}{llll}80.45 & 1.34 & 0.51 & 2.40\end{array}$

$\begin{array}{llll}81.10 & 1.45 & 0.61 & 2.77\end{array}$

$\begin{array}{lllll}78.78 & 1.38 & 0.57 & 2.64\end{array}$

$\begin{array}{llll}86.77 & 1.27 & 0.38 & 2.19 \\ 80.07 & 1.32 & 0.50 & 2.39\end{array}$

$\begin{array}{llll}82.18 & 1.31 & 0.46 & 2.39\end{array}$

$\begin{array}{llll}82.59 & 1.33 & 0.48 & 2.43\end{array}$

$\begin{array}{llll}82.19 & 1.37 & 0.53 & 2.72\end{array}$

$\begin{array}{llll}79.51 & 1.38 & 0.56 & 2.64 \\ 76.35 & 1.39 & 0.61 & 2.53\end{array}$

$\begin{array}{llll}77.22 & 1.39 & 0.60 & 2.45\end{array}$

$\begin{array}{llll}62.30 & 1.71 & 1.07 & 2.33\end{array}$

$\begin{array}{llll}78.86 & 1.42 & 0.61 & 2.63\end{array}$

$\begin{array}{ll}79.18 & 1.35 \\ 78.28 & 1.38\end{array}$

Hole 701B:

1H-1, 100-102

$1 \mathrm{H}-2,100-102$

$1 \mathrm{H}-3,100-102$

$1 \mathrm{H}-4,100-102$

$2 \mathrm{H}-1,100-102$

$2 \mathrm{H}-2,100-102$

$2 \mathrm{H}-3,100-102$

$2 \mathrm{H}-4,100-102$

$3 \mathrm{H}-2,100-102$

$3 \mathrm{H}-3,100-102$

$3 \mathrm{H}-4,100-102$

$3 \mathrm{H}-5,100-102$

$4 \mathrm{H}-3,100-102$

$4 \mathrm{H}-4,100-102$

$4 \mathrm{H}-5,100-102$

$4 \mathrm{H}-6,100-102$

$5 \mathrm{H}-1,100-102$

$5 \mathrm{H}-2,100-102$

$5 \mathrm{H}-3,100-102$

5H-4, 100-102

$5 \mathrm{H}-5,100-102$

5H-6, 100-102

$6 \mathrm{H}-1,110-112$

$6 \mathrm{H}-2,98-100$

$6 \mathrm{H}-3,26-27$
$6 \mathrm{H}-3,100-102$

$6 \mathrm{H}-4,47-49$

$6 \mathrm{H}-4,85-86$

7H-1, 101-103

7H-2, 79-81

7H-2, 123-124

$7 \mathrm{H}-3,50-52$

$7 \mathrm{H}-4,100-102$

$8 \mathrm{H}-1,21-22$

$0.00 \quad 80.50$

$\begin{array}{ll}75.50 & 67.73 \\ 77.00 & 53.45\end{array}$

$80.50 \quad 62.13$

$\begin{array}{ll}82.00 & 59.58 \\ 83.50 & 65.18\end{array}$

$\begin{array}{ll}83.50 & 65.18 \\ 85.00 & 66.79\end{array}$

$90.00 \quad 60.97$

$91.50 \quad 68.40$

$93.00 \quad 65.13$

$94.50 \quad 67.58$

96.00

$101.00 \quad 58.6$

$102.50 \quad 70.73$

$104.00 \quad 60.36$

$\begin{array}{ll}105.50 & 56.44 \\ 107.00 & 56.76\end{array}$

$109.00 \quad 63.78$

$110.50 \quad 65.51$

$112.00 \quad 69.59$

$113.50 \quad 66.95$

$115.00 \quad 56.25$

116.50

118.60

120.76

121.50

60.60

55.96

49.31
55.85

59.52

122.85

129.29

129.73

55.48
61.41

56.01
60.43

60.43

$132.50 \quad 56.64$

$133.99 \quad 54.75$

$8 \mathrm{H}-1,98-100$

137.48

Table 10 (continued).

\begin{tabular}{|c|c|c|c|c|c|c|}
\hline \multirow[b]{2}{*}{$\begin{array}{c}\text { Sample } \\
(\mathrm{cm})\end{array}$} & \multirow[b]{2}{*}{$\begin{array}{l}\text { Depth } \\
\text { (mbsf) }\end{array}$} & \multirow[b]{2}{*}{$\begin{array}{c}\text { Water } \\
\text { content } \\
(\%)\end{array}$} & \multirow[b]{2}{*}{$\begin{array}{c}\text { Porosity } \\
(\%)\end{array}$} & \multicolumn{3}{|c|}{ Densities } \\
\hline & & & & $\begin{array}{c}\text { Wet } \\
\text { bulk } \\
\left(\mathrm{g} / \mathrm{cm}^{3}\right)\end{array}$ & $\begin{array}{c}\text { Dry } \\
\text { bulk } \\
\left(\mathrm{g} / \mathrm{cm}^{3}\right)\end{array}$ & $\begin{array}{l}\text { Grain } \\
\left(\mathrm{g} / \mathrm{cm}^{3}\right)\end{array}$ \\
\hline \multicolumn{7}{|l|}{ Hole 701B (Cont.): } \\
\hline $8 \mathrm{H}-2,98-100$ & 138.98 & 55.65 & 75.65 & 1.39 & 0.62 & 2.62 \\
\hline $8 \mathrm{H}-3,99-101$ & 140.49 & 51.43 & 74.38 & 1.48 & 0.72 & 2.93 \\
\hline $8 \mathrm{H}-4,100-102$ & 142.00 & 54.01 & 75.04 & 1.42 & 0.65 & 2.55 \\
\hline $8 \mathrm{H}-5,50-52$ & 143.00 & 56.80 & 78.54 & 1.42 & 0.61 & 2.87 \\
\hline $9 \mathrm{H}-2,90-92$ & 148.40 & 74.31 & 95.25 & 1.31 & 0.34 & \\
\hline $10 \mathrm{H}-1,100-102$ & 156.50 & 70.83 & 92.77 & 1.34 & 0.39 & \\
\hline $13 \times-1,100-102$ & 185.00 & 61.38 & 81.95 & 1.37 & 0.53 & 2.61 \\
\hline $13 X-2,100-102$ & 186.50 & 62.07 & 82.94 & 1.37 & 0.52 & 2.38 \\
\hline $13 X-3,100-102$ & 188.00 & 65.03 & 83.09 & 1.31 & 0.46 & 2.61 \\
\hline $13 \times-4,100-102$ & 189.50 & 60.12 & 78.98 & 1.35 & 0.54 & 2.57 \\
\hline $14 \mathrm{X}-1,100-102$ & 194.50 & 60.67 & 82.38 & 1.39 & 0.55 & 2.61 \\
\hline $14 \mathrm{X}-2,100-102$ & 196.00 & 61.88 & 82.95 & 1.37 & 0.52 & 2.50 \\
\hline $14 X-3,100-102$ & 197.50 & 62.31 & 81.26 & 1.34 & 0.50 & 2.84 \\
\hline $14 \times-4,100-102$ & 199.00 & 61.49 & 81.18 & 1.35 & 0.52 & 2.53 \\
\hline $14 X-5,100-102$ & 200.50 & 62.85 & 82.13 & 1.34 & 0.50 & 2.35 \\
\hline $14 \mathrm{X}-6,100-102$ & 202.00 & 62.47 & 83.43 & 1.37 & 0.51 & 2.51 \\
\hline
\end{tabular}

Hole 701C:

\begin{tabular}{|c|c|c|c|c|c|c|}
\hline $2 \mathrm{H}-3,130-132$ & 10.60 & 68.55 & 86.26 & 1.29 & 0.41 & 2.72 \\
\hline $3 \mathrm{H}-2,100-102$ & 18.30 & 65.65 & 82.64 & 1.29 & 0.44 & 2.46 \\
\hline $3 \mathrm{H}-5,100-102$ & 22.80 & 50.92 & 73.95 & 1.49 & 0.73 & 2.72 \\
\hline $4 \mathrm{H}-2,100-102$ & 27.80 & 74.92 & 89.01 & 1.22 & 0.31 & 2.69 \\
\hline $4 \mathrm{H}-4,100-102$ & 30.80 & 74.11 & 88.31 & 1.22 & 0.32 & 2.58 \\
\hline $4 \mathrm{H}-6,100-102$ & 33.80 & 63.92 & 83.09 & 1.33 & 0.48 & 2.80 \\
\hline $5 \mathrm{H}-2,101-103$ & 37.31 & 68.89 & 87.05 & 1.29 & 0.40 & 2.44 \\
\hline $5 \mathrm{H}-4,121-123$ & 40.51 & 54.43 & 78.27 & 1.47 & 0.67 & 3.26 \\
\hline $6 \mathrm{H}-2,80-82$ & 46.60 & 60.34 & 83.65 & 1.42 & 0.56 & 2.68 \\
\hline $6 \mathrm{H}-4,99-101$ & 49.79 & 66.83 & 85.15 & 1.31 & 0.43 & 2.50 \\
\hline $7 \mathrm{H}-1,100-102$ & 54.80 & 63.17 & 85.86 & 1.39 & 0.51 & 3.29 \\
\hline $7 \mathrm{H}-4,100-102$ & 59.30 & 64.75 & 85.20 & 1.35 & 0.48 & 2.36 \\
\hline $8 \mathrm{H}-3,100-102$ & 67.30 & 61.62 & 84.42 & 1.40 & 0.54 & 2.63 \\
\hline $9 \mathrm{H}-1,120-122$ & 74.00 & 67.65 & 86.28 & 1.31 & 0.42 & 2.59 \\
\hline $9 \mathrm{H}-4,100-102$ & 78.30 & 58.92 & 82.48 & 1.43 & 0.59 & 3.01 \\
\hline $10 \mathrm{H}-3,100-102$ & 86.30 & 58.41 & 84.23 & 1.48 & 0.61 & 2.96 \\
\hline $10 \mathrm{H}-4,100-102$ & 87.80 & 61.57 & 84.21 & 1.40 & 0.54 & 2.67 \\
\hline $11 \mathrm{H}-3,100-102$ & 95.80 & 67.59 & 87.56 & 1.33 & 0.43 & 2.42 \\
\hline $11 \mathrm{H}-4,100-102$ & 97.30 & 71.12 & 89.35 & 1.29 & 0.37 & 2.25 \\
\hline $11 \mathrm{H}-6,125-127$ & 100.55 & 70.25 & 88.33 & 1.29 & 0.38 & 2.35 \\
\hline $13 \mathrm{H}-1,100-102$ & 111.80 & 70.48 & 91.44 & 1.33 & 0.39 & 2.47 \\
\hline $13 \mathrm{H}-3,100-102$ & 114.80 & 62.54 & 86.75 & 1.42 & 0.53 & 2.84 \\
\hline $13 \mathrm{H}-4,100-102$ & 116.30 & 58.07 & 84.37 & 1.49 & 0.62 & 2.78 \\
\hline $13 \mathrm{H}-5,100-102$ & 117.80 & 56.48 & 81.74 & 1.48 & 0.65 & 2.81 \\
\hline $14 \mathrm{H}-2,100-102$ & 122.80 & 55.56 & 81.28 & 1.50 & 0.67 & 2.92 \\
\hline $14 \mathrm{H}-3,100-102$ & 124.30 & 62.35 & 84.70 & 1.39 & 0.52 & 2.45 \\
\hline $14 \mathrm{H}-4,100-102$ & 125.80 & 62.61 & 84.10 & 1.38 & 0.51 & 2.67 \\
\hline $14 \mathrm{H}-5,100-102$ & 127.30 & 57.17 & 80.68 & 1.45 & 0.62 & 2.73 \\
\hline $14 \mathrm{H}-6,100-102$ & 128.80 & 54.64 & 80.82 & 1.52 & 0.69 & 2.83 \\
\hline $15 \mathrm{H}-2,100-102$ & 132.30 & 56.04 & 79.18 & 1.45 & 0.64 & 2.67 \\
\hline $15 \mathrm{H}-4,100-102$ & 135.30 & 58.43 & 80.57 & 1.41 & 0.59 & 2.59 \\
\hline $16 \mathrm{H}-1,100-102$ & 140.30 & 54.24 & 77.86 & 1.47 & 0.67 & 2.94 \\
\hline $16 \mathrm{H}-2,101-103$ & 141.81 & 57.64 & 80.55 & 1.43 & 0.61 & 2.89 \\
\hline $16 \mathrm{H}-3,101-103$ & 143.31 & 55.19 & 78.14 & 1.45 & 0.65 & 2.69 \\
\hline $16 \mathrm{H}-4,99-101$ & 144.79 & 53.75 & 77.80 & 1.48 & 0.69 & 2.78 \\
\hline $16 \mathrm{H}-5,100-102$ & 146.30 & 72.56 & 89.87 & 1.27 & 0.35 & 2.44 \\
\hline $16 \mathrm{H}-6,100-102$ & 147.80 & 72.99 & 88.37 & 1.24 & 0.34 & 2.27 \\
\hline $17 \mathrm{H}-1,100-102$ & 149.80 & 72.33 & 89.80 & 1.27 & 0.35 & 2.36 \\
\hline $17 \mathrm{H}-2,101-103$ & 151.31 & 73.22 & 88.17 & 1.23 & 0.33 & 2.14 \\
\hline $17 \mathrm{H}-3,80-82$ & 152.60 & 72.29 & 89.43 & 1.27 & 0.35 & 2.40 \\
\hline $17 \mathrm{H}-4,99-101$ & 153.77 & 71.79 & 88.11 & 1.26 & 0.35 & 2.24 \\
\hline $17 \mathrm{H}-5,99-101$ & 155.27 & 72.57 & 89.86 & 1.27 & 0.35 & 2.36 \\
\hline $17 \mathrm{H}-6,99-101$ & 156.77 & 73.31 & 89.00 & 1.24 & 0.33 & 2.17 \\
\hline $18 \mathrm{H}-2,89-91$ & 160.69 & 74.40 & 90.09 & 1.24 & 0.32 & 2.19 \\
\hline $19 \mathrm{H}-1,99-101$ & 168.79 & 67.89 & 84.66 & 1.28 & 0.41 & 2.25 \\
\hline $20 \mathrm{H}-1,98-100$ & 178.28 & 58.25 & 79.86 & 1.40 & 0.59 & 2.51 \\
\hline $20 \mathrm{H}-2,98-100$ & 179.78 & 58.20 & 79.19 & 1.39 & 0.58 & 2.67 \\
\hline $20 \mathrm{H}-3,98-100$ & 181.28 & 59.28 & 80.90 & 1.40 & 0.57 & 2.70 \\
\hline $20 \mathrm{H}-4,98-100$ & 182.78 & 58.52 & 78.55 & 1.38 & 0.57 & 2.38 \\
\hline $20 \mathrm{H}-5,98-100$ & 184.28 & 57.19 & 80.18 & 1.44 & 0.61 & 2.59 \\
\hline $21 \mathrm{H}-1,98-100$ & 187.78 & 64.35 & 83.62 & 1.33 & 0.47 & 2.50 \\
\hline $21 \mathrm{H}-2,98-100$ & 189.28 & 60.49 & 79.79 & 1.35 & 0.53 & 2.54 \\
\hline $21 \mathrm{H}-3,13-14$ & 189.93 & 38.19 & 66.31 & 1.78 & 1.10 & 2.66 \\
\hline $22 \mathrm{H}-3,100-102$ & 200.30 & 61.92 & 84.30 & 1.39 & 0.53 & 2.67 \\
\hline $22 \mathrm{H}-4,100-102$ & 201.80 & 59.32 & 80.99 & 1.40 & 0.57 & 2.69 \\
\hline $22 \mathrm{H}-5,100-102$ & 203.30 & 56.90 & 80.50 & 1.45 & 0.62 & 2.68 \\
\hline $22 \mathrm{H}-6,100-102$ & 204.80 & 59.02 & 80.90 & 1.40 & 0.58 & 2.57 \\
\hline $23 \mathrm{H}-1,100-102$ & 206.80 & 58.51 & 82.64 & 1.45 & 0.60 & 3.07 \\
\hline $23 \mathrm{H}-2,100-102$ & 208.30 & 55.84 & 80.29 & 1.47 & 0.65 & 2.86 \\
\hline $23 \mathrm{H}-3,90-92$ & 209.70 & 56.82 & 83.54 & 1.51 & 0.65 & 3.13 \\
\hline $23 \mathrm{H}-4,100-102$ & 211.30 & 59.43 & 83.25 & 1.44 & 0.58 & 2.81 \\
\hline $23 \mathrm{H}-5,100-102$ & 212.80 & 58.95 & 80.73 & 1.40 & 0.58 & 2.72 \\
\hline
\end{tabular}


Table 10 (continued).

\begin{tabular}{|c|c|c|c|c|c|c|}
\hline \multirow[b]{2}{*}{$\begin{array}{c}\text { Sample } \\
(\mathrm{cm})\end{array}$} & \multirow[b]{2}{*}{$\begin{array}{l}\text { Depth } \\
\text { (mbsf) }\end{array}$} & \multirow[b]{2}{*}{$\begin{array}{c}\text { Water } \\
\text { content } \\
(\%)\end{array}$} & \multirow[b]{2}{*}{$\begin{array}{c}\text { Porosity } \\
(\%)\end{array}$} & \multicolumn{3}{|c|}{ Densities } \\
\hline & & & & $\begin{array}{c}\text { Wet } \\
\text { bulk } \\
\left(\mathrm{g} / \mathrm{cm}^{3}\right)\end{array}$ & $\begin{array}{c}\text { Dry } \\
\text { bulk } \\
\left(\mathrm{g} / \mathrm{cm}^{3}\right)\end{array}$ & $\begin{array}{c}\text { Grain } \\
\left(\mathrm{g} / \mathrm{cm}^{3}\right)\end{array}$ \\
\hline \multicolumn{7}{|l|}{ Hole 701C (Cont.): } \\
\hline $24 \mathrm{H}-1,100-102$ & 216.30 & 63.51 & 86.82 & 1.40 & 0.51 & 2.89 \\
\hline $24 \mathrm{H}-2,100-102$ & 217.80 & 62.30 & 84.68 & 1.39 & 0.52 & 2.79 \\
\hline $24 \mathrm{H}-3,100-102$ & 219.30 & 58.05 & 80.13 & 1.41 & 0.59 & 2.44 \\
\hline $24 \mathrm{H}-4,100-102$ & 220.80 & 60.50 & 81.20 & 1.38 & 0.54 & 2.48 \\
\hline $24 \mathrm{H}-5,100-102$ & 222.30 & 61.70 & 83.37 & 1.38 & 0.53 & 2.47 \\
\hline $24 \mathrm{H}-6,100-102$ & 223.80 & 58.33 & 80.40 & 1.41 & 0.59 & 2.68 \\
\hline $25 \mathrm{X}-1,100-102$ & 225.80 & 64.49 & 90.16 & 1.43 & 0.51 & 2.64 \\
\hline $25 \mathrm{X}-2,100-102$ & 227.30 & 62.81 & 83.18 & 1.36 & 0.50 & 2.44 \\
\hline $25 X-3,100-102$ & 228.80 & 60.35 & 81.44 & 1.38 & 0.55 & 2.59 \\
\hline $25 X-4,100-102$ & 230.30 & 56.96 & 83.09 & 1.49 & 0.64 & 2.30 \\
\hline $25 X-4,100-102$ & 230.30 & 56.96 & 83.09 & 1.49 & 0.64 & 2.30 \\
\hline $26 \mathrm{X}-1,100-102$ & 235.30 & 53.97 & 78.00 & 1.48 & 0.68 & 2.94 \\
\hline $27 \mathrm{X}-1,100-102$ & 244.80 & 54.72 & 81.02 & 1.52 & 0.69 & 2.90 \\
\hline $27 X-2,100-102$ & 246.30 & 55.00 & 79.71 & 1.48 & 0.67 & 2.88 \\
\hline $27 X-3,100-102$ & 247.80 & 48.75 & 73.96 & 1.55 & 0.80 & 2.94 \\
\hline $27 X-4,40-42$ & 248.70 & 51.81 & 75.32 & 1.49 & 0.72 & 2.75 \\
\hline $27 X-5,130-132$ & 248.10 & 54.33 & 78.53 & 1.48 & 0.68 & 2.74 \\
\hline $29 \mathrm{X}-1,100-102$ & 263.80 & 62.20 & 83.73 & 1.38 & 0.52 & 2.80 \\
\hline $29 X-2,100-102$ & 265.30 & 62.14 & 84.79 & 1.40 & 0.53 & 2.66 \\
\hline $29 X-3,100-102$ & 266.80 & 60.33 & 82.00 & 1.39 & 0.55 & 2.93 \\
\hline $29 \mathrm{X}-4,100-102$ & 268.30 & 59.58 & 81.55 & 1.40 & 0.57 & 2.74 \\
\hline $29 \mathrm{X}-6,100-102$ & 271.30 & 61.02 & 84.11 & 1.41 & 0.55 & 2.86 \\
\hline $31 X-1,100-102$ & 282.80 & 51.69 & 78.22 & 1.55 & 0.75 & 3.15 \\
\hline $31 X-4,100-102$ & 287.30 & 61.36 & 82.05 & 1.37 & 0.53 & 2.76 \\
\hline $32 X-1,100-102$ & 292.30 & 61.68 & 83.54 & 1.39 & 0.53 & 2.91 \\
\hline $32 X-3,98-100$ & 295.28 & 60.70 & 81.84 & 1.38 & 0.54 & 2.99 \\
\hline $32 X-5,100-102$ & 298.30 & 60.64 & 83.21 & 1.41 & 0.55 & 2.96 \\
\hline $34 \mathrm{X}-1,98-100$ & 311.28 & 61.22 & 82.87 & 1.39 & 0.54 & 2.84 \\
\hline $34 X-3,90-92$ & 314.20 & 61.88 & 83.76 & 1.39 & 0.53 & 2.83 \\
\hline $34 X-5,110-112$ & 317.40 & 62.51 & 83.80 & 1.37 & 0.51 & 2.67 \\
\hline $35 X-1,100-102$ & 320.80 & 61.81 & 84.12 & 1.39 & 0.53 & 2.74 \\
\hline $35 X-3,101-103$ & 322.50 & 62.13 & 81.82 & 1.35 & 0.51 & 2.84 \\
\hline $35 X-4,101-103$ & 324.00 & 60.95 & 82.16 & 1.38 & 0.54 & 2.95 \\
\hline $35 X-5,100-102$ & 325.49 & 61.39 & 83.28 & 1.39 & 0.54 & 2.58 \\
\hline $35 X-7,85-87$ & 328.34 & 61.88 & 82.76 & 1.37 & 0.52 & 2.74 \\
\hline $36 \mathrm{X}-1,100-102$ & 330.30 & 60.95 & 82.08 & 1.38 & 0.54 & 2.81 \\
\hline $37 X-2,90-92$ & 341.20 & 60.84 & 81.45 & 1.37 & 0.54 & 2.70 \\
\hline $37 \times-4,90-92$ & 344.20 & 61.74 & 82.73 & 1.37 & 0.53 & 2.75 \\
\hline $38 \mathrm{X}-1,100-102$ & 349.30 & 62.88 & 83.34 & 1.36 & 0.50 & 2.67 \\
\hline $38 X-2,100-102$ & 350.80 & 60.39 & 83.92 & 1.42 & 0.56 & 2.73 \\
\hline $42 X-1,100-102$ & 387.30 & 38.66 & 66.77 & 1.77 & 1.09 & 2.94 \\
\hline $42 X-2,10-12$ & 387.90 & 37.91 & 65.21 & 1.76 & 1.09 & 2.95 \\
\hline $43 X-1,100-102$ & 396.80 & 56.29 & 77.89 & 1.42 & 0.62 & 2.62 \\
\hline $43 X-2,100-102$ & 398.30 & 57.27 & 79.01 & 1.41 & 0.60 & 2.57 \\
\hline $43 X-3,100-102$ & 399.80 & 54.34 & 80.16 & 1.51 & 0.69 & 2.94 \\
\hline $43 X-4,100-102$ & 401.30 & 54.39 & 79.07 & 1.49 & 0.68 & 2.78 \\
\hline $43 X-5,100-102$ & 402.80 & 52.36 & 75.93 & 1.49 & 0.71 & 2.66 \\
\hline $43 X-6,100-102$ & 404.30 & 53.19 & 77.48 & 1.49 & 0.70 & 2.90 \\
\hline $44 X-2,100-102$ & 407.80 & 54.38 & 79.73 & 1.50 & 0.69 & 2.64 \\
\hline $44 X-3,100-102$ & 409.30 & 53.08 & 78.47 & 1.51 & 0.71 & 2.58 \\
\hline $44 X-4,100-102$ & 410.80 & 50.89 & 78.09 & 1.57 & 0.77 & 2.52 \\
\hline $44 X-5,100-102$ & 412.30 & 46.00 & 71.62 & 1.60 & 0.86 & 2.72 \\
\hline $44 X-6,100-102$ & 413.80 & 58.70 & 83.67 & 1.46 & 0.60 & 2.73 \\
\hline $45 X-2,110-112$ & 417.40 & 54.62 & 81.49 & 1.53 & 0.69 & 2.79 \\
\hline $45 X-4,100-102$ & 420.30 & 57.76 & 82.37 & 1.46 & 0.62 & 2.53 \\
\hline $47 X-2,102-104$ & 436.32 & 60.20 & 85.37 & 1.45 & 0.58 & 2.71 \\
\hline $47 X-3,102-104$ & 437.82 & 63.00 & 89.78 & 1.46 & 0.54 & 2.84 \\
\hline $47 X-6,103-105$ & 442.33 & 55.13 & 88.91 & 1.65 & 0.74 & 3.26 \\
\hline $49 X-2,101-103$ & 455.31 & 29.79 & 58.92 & 2.03 & 1.42 & 2.97 \\
\hline $49 X-3,74-76$ & 456.54 & 33.92 & 63.72 & 1.92 & 1.27 & 2.64 \\
\hline $49 X-4,100-102$ & 458.30 & 29.50 & 56.26 & 1.95 & 1.38 & 2.83 \\
\hline $49 X-5,67-69$ & 459.47 & 32.27 & 66.96 & 2.13 & 1.44 & 3.46 \\
\hline $49 X-6,11-13$ & 460.41 & 35.12 & 64.45 & 1.88 & 1.22 & 2.86 \\
\hline
\end{tabular}

ences between the subunits, however, give rise to dramatic differences in the physical properties. Subunit IA (0-74.8 mbsf, Hole 701A; 0-147.5 mbsf, Hole 701B; 0-145.5 mbsf, Hole 701C; lower Pliocene to Quaternary) is an ash- and/or mudbearing diatom ooze. The thickness of some of the ash layers is on a centimeter scale, and these layers have identifiable spikes in wet-bulk density, porosity, water content, and grain density values (Fig. 27). The major peak in the thermal conductivity (Section $114-701 \mathrm{~A}-3 \mathrm{H}-1 ; 18.80 \mathrm{mbsf})$ most likely results from the proximity of a manganese nodule layer.
Table 11. Carbonate content, Site 701.

\begin{tabular}{|c|c|c|}
\hline $\begin{array}{c}\text { Sample } \\
\text { (cm) }\end{array}$ & $\begin{array}{l}\text { Depth } \\
\text { (mbsf) }\end{array}$ & $\begin{array}{c}\text { Carbonate } \\
\text { content } \\
(\%)\end{array}$ \\
\hline \multicolumn{3}{|l|}{ Hole 701A: } \\
\hline $1 \mathrm{H}-4,100-102$ & 5.50 & 0.42 \\
\hline $1 \mathrm{H}-5,100-102$ & 7.00 & 0.25 \\
\hline 1H-6, 60-62 & 8.10 & 0.17 \\
\hline $2 \mathrm{H}-1,100-102$ & 9.30 & 0.17 \\
\hline $2 \mathrm{H}-2,100-102$ & 10.80 & 0.08 \\
\hline $2 \mathrm{H}-3,100-102$ & 12.30 & 0.25 \\
\hline $2 \mathrm{H}-4,100-102$ & 13.80 & 0.08 \\
\hline $2 \mathrm{H}-5,100-102$ & 15.30 & 0.08 \\
\hline $2 \mathrm{H}-6,100-102$ & 16.80 & 0.08 \\
\hline $3 \mathrm{H}-1,100-102$ & 18.80 & 0.08 \\
\hline $3 \mathrm{H}-3,100-102$ & 21.80 & 0.75 \\
\hline $3 \mathrm{H}-5,100-102$ & 24.80 & 0.58 \\
\hline $4 \mathrm{H}-3,100-102$ & 31.30 & 4.25 \\
\hline $5 \mathrm{H}-1,100-102$ & 37.80 & 10.76 \\
\hline $5 \mathrm{H}-2,100-102$ & 39.30 & 9.34 \\
\hline $5 \mathrm{H}-3,100-102$ & 40.80 & 0.00 \\
\hline $5 \mathrm{H}-4,100-102$ & 42.30 & 0.25 \\
\hline $5 \mathrm{H}-5,100-102$ & 43.80 & 0.17 \\
\hline $5 \mathrm{H}-6,100-102$ & 45.30 & 0.17 \\
\hline $6 \mathrm{H}-3,100-102$ & 50.30 & 0.17 \\
\hline $6 \mathrm{H}-4,100-102$ & 51.80 & 0.25 \\
\hline $6 \mathrm{H}-5,100-102$ & 53.30 & 0.17 \\
\hline $6 \mathrm{H}-6,100-102$ & 54.80 & 0.33 \\
\hline $7 \mathrm{H}-1,100-102$ & 56.80 & 0.17 \\
\hline $7 \mathrm{H}-2,100-102$ & 58.30 & 0.17 \\
\hline $7 \mathrm{H}-3,100-102$ & 59.80 & 0.25 \\
\hline $7 \mathrm{H}-4,100-102$ & 61.30 & 0.25 \\
\hline $8 \mathrm{H}-1,100-102$ & 66.30 & 0.25 \\
\hline $8 \mathrm{H}-2,100-102$ & 67.80 & 0.08 \\
\hline $8 \mathrm{H}-3,100-102$ & 69.30 & 0.25 \\
\hline $8 \mathrm{H}-4,100-102$ & 70.80 & 0.17 \\
\hline $8 \mathrm{H}-5,100-102$ & 72.30 & 0.25 \\
\hline $8 \mathrm{H}-6,100-102$ & 73.80 & 0.17 \\
\hline
\end{tabular}

Hole 701B:

$\begin{array}{lrl}1 \mathrm{H}-1,100-102 & 71.00 & 0.00 \\ 1 \mathrm{H}-2,100-102 & 72.50 & 0.00 \\ 1 \mathrm{H}-3,100-102 & 74.00 & 0.00 \\ 1 \mathrm{H}-4,100-102 & 75.50 & 0.00 \\ 1 \mathrm{H}-5,100-102 & 77.00 & 0.00 \\ 2 \mathrm{H}-1,100-102 & 80.50 & 0.00 \\ 2 \mathrm{H}-2,100-102 & 82.00 & 0.00 \\ 2 \mathrm{H}-3,100-102 & 83.50 & 0.00 \\ 2 \mathrm{H}-4,100-102 & 85.00 & 0.00 \\ 3 \mathrm{H}-1,100-102 & 90.00 & 0.00 \\ 3 \mathrm{H}-2,100-102 & 91.50 & 0.00 \\ 3 \mathrm{H}-3,100-102 & 93.00 & 0.00 \\ 3 \mathrm{H}-4,100-102 & 94.50 & 0.00 \\ 3 \mathrm{H}-5,100-102 & 96.00 & 0.00 \\ 4 \mathrm{H}-2,100-102 & 101.00 & 0.00 \\ 4 \mathrm{H}-3,100-102 & 102.50 & 0.00 \\ 4 \mathrm{H}-4,100-102 & 104.00 & 0.00 \\ 4 \mathrm{H}-5,100-102 & 105.50 & 0.00 \\ 4 \mathrm{H}-6,100-102 & 107.00 & 0.00 \\ 5 \mathrm{H}-1,100-102 & 109.00 & 0.00 \\ 5 \mathrm{H}-2,100-102 & 110.50 & 0.00 \\ 5 \mathrm{H}-3,100-102 & 112.00 & 0.00 \\ 5 \mathrm{H}-4,100-102 & 113.50 & 0.00 \\ 5 \mathrm{H}-5,100-102 & 115.00 & 0.00 \\ 5 \mathrm{H}-6,100-102 & 116.50 & 0.00 \\ 6 \mathrm{H}-1,110-112 & 118.60 & 0.00 \\ 6 \mathrm{H}-2,98-100 & 119.98 & 0.00 \\ 6 \mathrm{H}-3,26-27 & 120.76 & 0.00 \\ 7 \mathrm{H}-1,101-103 & 128.01 & 0.00 \\ 8 \mathrm{H}-1,98-100 & 137.48 & 0.00 \\ 8 \mathrm{H}-5,100-102 & 143.50 & 0.00 \\ 10 \mathrm{H}-1,100-102 & 156.50 & 0.83 \\ 13 \mathrm{X}-1,100-102 & 185.00 & 0.83 \\ 14 \mathrm{X}-1,100-102 & 194.50 & 0.83\end{array}$

Hole 701C:

$\begin{array}{lll}2 \mathrm{H}-3,130-132 & 10.60 & 0.08 \\ 3 \mathrm{H}-2,100-102 & 18.30 & 0.17\end{array}$ 
Table 12. $P$-wave velocity, Holes $701 B$ and $701 C$.

Table 11 (continued).

\begin{tabular}{|c|c|c|}
\hline $\begin{array}{c}\text { Sample } \\
\text { (cm) }\end{array}$ & $\begin{array}{l}\text { Depth } \\
\text { (mbsf) }\end{array}$ & $\begin{array}{c}\text { Carbonate } \\
\text { content } \\
(\%)\end{array}$ \\
\hline \multicolumn{3}{|l|}{ Hole 701C (Cont.): } \\
\hline $4 \mathrm{H}-2,100-102$ & 27.80 & 0.17 \\
\hline $5 \mathrm{H}-2,100-103$ & 37.31 & 10.76 \\
\hline $6 \mathrm{H}-2,80-82$ & 46.60 & 0.08 \\
\hline $7 \mathrm{H}-1,100-102$ & 54.80 & 0.17 \\
\hline $8 \mathrm{H}-3,100-102$ & 67.30 & 0.17 \\
\hline $9 \mathrm{H}-1,120-122$ & 74.00 & 0.17 \\
\hline $9 \mathrm{H}-4,100-102$ & 78.30 & 0.50 \\
\hline $10 \mathrm{H}-3,100-102$ & 86.30 & 0.42 \\
\hline $10 \mathrm{H}-4,100-102$ & 87.80 & 0.17 \\
\hline $11 \mathrm{H}-3,100-102$ & 95.80 & 0.17 \\
\hline $13 \mathrm{H}-1,100-102$ & 111.80 & 0.17 \\
\hline $14 \mathrm{H}-2,100-102$ & 122.80 & 0.17 \\
\hline $15 \mathrm{H}-2,100-102$ & 132.30 & 0.58 \\
\hline $16 \mathrm{H}-1,100-102$ & 140.30 & 0.17 \\
\hline $16 \mathrm{H}-2,101-103$ & 141.81 & 0.08 \\
\hline $16 \mathrm{H}-3,101-103$ & 143.31 & 0.17 \\
\hline $16 \mathrm{H}-4,130-131$ & 145.10 & 0.25 \\
\hline $16 \mathrm{H}-5,10-11$ & 145.40 & 0.25 \\
\hline $16 \mathrm{H}-5,30-31$ & 145.60 & 0.17 \\
\hline $16 \mathrm{H}-5,60-61$ & 145.90 & 0.25 \\
\hline $16 \mathrm{H}-5,120-121$ & 146.50 & 0.33 \\
\hline $16 \mathrm{H}-6,100-102$ & 147.80 & 5.50 \\
\hline $17 \mathrm{H}-1,100-102$ & 149.80 & 0.25 \\
\hline $17 \mathrm{H}-2,101-103$ & 151.31 & 0.50 \\
\hline $17 \mathrm{H}-3,80-82$ & 152.60 & 0.08 \\
\hline $17 \mathrm{H}-4,99-101$ & 153.77 & 0.33 \\
\hline $17 \mathrm{H}-5,99-101$ & 155.27 & 0.33 \\
\hline $17 \mathrm{H}-6,99-101$ & 156.77 & 0.42 \\
\hline $18 \mathrm{H}-2,89-91$ & 160.69 & 0.25 \\
\hline $19 \mathrm{H}-1,99-101$ & 168.79 & 0.17 \\
\hline $20 \mathrm{H}-1,98-100$ & 178.28 & 0.17 \\
\hline $21 \mathrm{H}-1,98-100$ & 187.78 & 0.17 \\
\hline $22 \mathrm{H}-3,100-102$ & 200.30 & 0.17 \\
\hline $23 \mathrm{H}-1,100-102$ & 206.80 & 0.08 \\
\hline $24 \mathrm{H}-1,100-102$ & 216.30 & 0.17 \\
\hline $25 X-1,100-102$ & 225.80 & 0.08 \\
\hline $26 \mathrm{X}-1,100-102$ & 235.30 & 3.25 \\
\hline $27 \mathrm{X}-1,100-102$ & 244.80 & 0.08 \\
\hline $29 X-1,100-102$ & 263.80 & 0.17 \\
\hline $31 X-1,100-102$ & 282.80 & 18.35 \\
\hline $31 \times-4,100-102$ & 287.30 & 0.42 \\
\hline $32 X-1,100-102$ & 292.30 & 0.08 \\
\hline $34 X-1,98-100$ & 311.28 & 0.08 \\
\hline $35 X-1,100-102$ & 320.80 & 0.42 \\
\hline $36 \mathrm{X}-1,100-102$ & 330.30 & 0.25 \\
\hline $37 X-2,90-92$ & 341.20 & 0.17 \\
\hline $38 \mathrm{X}-1,100-102$ & 349.30 & 1.00 \\
\hline $42 X-1,100-102$ & 387.30 & 0.17 \\
\hline $43 \times-1,100-102$ & 396.80 & 0.17 \\
\hline $43 \mathrm{X}-2,100-102$ & 398.30 & 7.17 \\
\hline $43 X-3,100-102$ & 399.80 & 4.42 \\
\hline $43 X-4,100-102$ & 401.30 & 1.33 \\
\hline $43 X-5,100-102$ & 402.80 & 28.86 \\
\hline $43 X-6,100-102$ & 404.30 & 1.58 \\
\hline $44 X-2,100-102$ & 407.80 & 20.60 \\
\hline $44 X-3,100-102$ & 409.30 & 23.27 \\
\hline $44 X-4,100-102$ & 410.80 & 40.95 \\
\hline $44 X-5,100-102$ & 412.30 & 46.70 \\
\hline $44 X-6,100-102$ & 413.80 & 5.25 \\
\hline $45 X-2,110-112$ & 417.40 & 0.17 \\
\hline $45 X-4,100-102$ & 420.30 & 9.76 \\
\hline $47 X-2,102-104$ & 436.32 & 14.43 \\
\hline $47 X-3,102-104$ & 437.82 & 4.59 \\
\hline $47 X-6,102-104$ & 442.32 & 13.09 \\
\hline $49 X-2,101-103$ & 455.31 & 69.06 \\
\hline $49 X-3,74-76$ & 456.54 & 82.07 \\
\hline $49 \times-4,100-102$ & 458.30 & 75.23 \\
\hline $49 X-5,67-69$ & 459.47 & 85.15 \\
\hline $49 X-6,11-13$ & 460.41 & 89.07 \\
\hline
\end{tabular}

\begin{tabular}{|c|c|c|c|}
\hline $\begin{array}{c}\text { Sample } \\
(\mathrm{cm})\end{array}$ & $\begin{array}{c}\text { Depth } \\
\text { (mbsf) }\end{array}$ & Direction ${ }^{\mathrm{a}}$ & $\begin{array}{c}\text { Velocity } \\
(\mathrm{m} / \mathrm{s})\end{array}$ \\
\hline \multicolumn{4}{|l|}{ Hole 701B: } \\
\hline $2 \mathrm{H}-3,50-52$ & 83.00 & c & 1501.9 \\
\hline $3 \mathrm{H}-2,50-52$ & 91.00 & C & 1546.7 \\
\hline $4 \mathrm{H}-3,50-52$ & 102.00 & C & $\begin{array}{r}1536.9 \\
1696\end{array}$ \\
\hline $4 \mathrm{H}-4,50-52$ & 103.50 & c & 1536.6 \\
\hline $5 \mathrm{H}-5,50-52$ & 114.50 & c & 1535.0 \\
\hline $6 \mathrm{H}-2,100-102$ & 120.00 & c & 1468.0 \\
\hline $6 \mathrm{H}-4,100-102$ & 123.00 & c & 1548.7 \\
\hline $7 \mathrm{H}-1,100-102$ & 128.00 & C & 1554.5 \\
\hline $7 \mathrm{H}-3,50-52$ & 130.50 & c & 1557.3 \\
\hline 7H-5, 100-102 & 134.00 & $\mathrm{C}$ & $\begin{array}{l}1548.9 \\
103 .\end{array}$ \\
\hline $8 \mathrm{H}-1,100-102$ & 137.50 & C & 1535.5 \\
\hline $8 \mathrm{H}-3,100-102$ & 140.50 & C & 1559.5 \\
\hline $8 \mathrm{H}-5,101-103$ & 143.51 & C & 1533.5 \\
\hline $13 \mathrm{X}-3,100-102$ & 188.00 & c & 1552.3 \\
\hline $14 X-4,100-102$ & 199.00 & c & 1547.0 \\
\hline \multicolumn{4}{|l|}{ Hole 701C: } \\
\hline $1 \mathrm{H}-1,50-52$ & 0.50 & C & 1438.6 \\
\hline $2 \mathrm{H}-3,130-132$ & 10.60 & c & 1556.6 \\
\hline $3 \mathrm{H}-2,100-102$ & 18.30 & C & 1552.3 \\
\hline $3 \mathrm{H}-5,100-102$ & 22.80 & c & 1561.0 \\
\hline $4 \mathrm{H}-2,100-102$ & 27.80 & C & 1565.1 \\
\hline $4 \mathrm{H}-4,100-102$ & 30.80 & c & 1553.6 \\
\hline $4 \mathrm{H}-6,100-102$ & 33.80 & c & 1578.3 \\
\hline $5 \mathrm{H}-2,100-102$ & 37.30 & c & 1568.9 \\
\hline $5 \mathrm{H}-4,120-122$ & 40.50 & c & 1558.7 \\
\hline $6 \mathrm{H}-2,80-82$ & 46.60 & C & 1558.4 \\
\hline $6 \mathrm{H}-4,100-102$ & 49.80 & c & 1562.2 \\
\hline $7 \mathrm{H}-1,50-52$ & 54.30 & c & 1567.3 \\
\hline $10 \mathrm{H}-4,100-102$ & 87.80 & c & 1537.3 \\
\hline $10 \mathrm{H}-5,100-102$ & 89.30 & c & 1604.9 \\
\hline $11 \mathrm{H}-4,50-52$ & 96.80 & c & 1568.1 \\
\hline $13 \mathrm{H}-1,100-102$ & 111.80 & c & 1459.5 \\
\hline $13 \mathrm{H}-2,50-52$ & 112.80 & c & 1573.7 \\
\hline $13 \mathrm{H}-4,50-52$ & 115.80 & c & 1543.4 \\
\hline $14 \mathrm{H}-2,50-52$ & 122.30 & c & 1570.0 \\
\hline $15 \mathrm{H}-2,100-102$ & 132.30 & c & 1557.6 \\
\hline $15 \mathrm{H}-4,100-102$ & 135.30 & c & 1569.0 \\
\hline $16 \mathrm{H}-2,100-102$ & 141.80 & c & 1546.8 \\
\hline $16 \mathrm{H}-4,100-102$ & 144.80 & c & 1570.6 \\
\hline $16 \mathrm{H}-6,100-102$ & 147.80 & c & 1615.9 \\
\hline $17 \mathrm{H}-1,100-102$ & 149.80 & C & 1590.5 \\
\hline $17 \mathrm{H}-2,100-102$ & 151.30 & c & 1537.2 \\
\hline $17 \mathrm{H}-4,100-102$ & 153.78 & C & 1525.0 \\
\hline $17 \mathrm{H}-6,100-102$ & 156.78 & C & 1532.0 \\
\hline $19 \mathrm{H}-1,100-102$ & 168.80 & c & 1579.5 \\
\hline $19 \mathrm{H}-1,125-127$ & 169.05 & c & 598.0 \\
\hline $20 \mathrm{H}-1,100-102$ & 178.30 & c & 1582.1 \\
\hline $20 \mathrm{H}-3,100-102$ & 181.30 & c & 1579.3 \\
\hline $20 \mathrm{H}-5,100-102$ & 184.30 & c & 1580.0 \\
\hline $2 \mathrm{IH}-1,100-102$ & 187.80 & c & 1568.2 \\
\hline $21 \mathrm{H}-2,100-102$ & 189.30 & C & 1590.4 \\
\hline $22 \mathrm{H}-3,100-102$ & 200.30 & c & 1562.8 \\
\hline $22 \mathrm{H}-6,100-102$ & 204.80 & c & 1558.3 \\
\hline $23 \mathrm{H}-1,50-52$ & 206.30 & C & 1564.0 \\
\hline $23 \mathrm{H}-4,50-52$ & 210.80 & c & 1568.3 \\
\hline $24 \mathrm{H}-2,50-52$ & 217.30 & c & 1567.2 \\
\hline $24 \mathrm{H}-3,100-102$ & 219.30 & c & 1561.7 \\
\hline $25 \mathrm{X}-3,100-102$ & 228.80 & c & 1543.5 \\
\hline $27 \times-1,50-52$ & 244.30 & c & 1570.5 \\
\hline $27 \mathrm{X}-2,100-102$ & 246.30 & c & 1573.5 \\
\hline $29 \times-2,100-102$ & 265.30 & c & 1441.3 \\
\hline $32 \times-1,100-102$ & 292.30 & c & 1554.6 \\
\hline $32 \mathrm{X}-3,98-100$ & 295.28 & c & 1551.2 \\
\hline $32 X-5,100-102$ & 298.30 & c & 1572.0 \\
\hline $34 X-1,100-102$ & 311.30 & C & 1567.6 \\
\hline $34 X-3,90-92$ & 314.2 & c & 1571.0 \\
\hline $34 X-5,110-112$ & 317. & c & 1573.0 \\
\hline $35 \times-3,100-102$ & 322.49 & c & 1576.3 \\
\hline $35 X-5,101-103$ & 325.50 & c & 1571.8 \\
\hline $35 \times-7,85-87$ & 328.3 & C & 1604.2 \\
\hline $35 X-7,85-87$ & 328. & c & 1604.2 \\
\hline $36 \mathrm{X}-1,100-102$ & 330.30 & c & 1542.9 \\
\hline $37 \times-2,90-92$ & 341.20 & C & 1575.1 \\
\hline $37 \times-4,90-92$ & 344.20 & c & 1551.8 \\
\hline $42 X-1,90-92$ & 387.20 & c & 1614.1 \\
\hline $43 \times-3,50-52$ & 399.3 & c & 1536.5 \\
\hline $44 X-4,100-102$ & 410.8 & c & 1564.9 \\
\hline $45 X-2,100-102$ & 417. & C & 1611.4 \\
\hline $45 X-5,80-82$ & 421. & c & 1590.2 \\
\hline $47 X-2,100-102$ & 436.30 & C & 1607.6 \\
\hline $47 \times-4,100-102$ & 439.30 & c & 1614.0 \\
\hline $47 \mathrm{X}-6,10-12$ & 441.40 & C & 1598.2 \\
\hline $52 \mathrm{X}, \mathrm{CC}$ & 481.00 & c & 4545.0 \\
\hline
\end{tabular}

a $\mathrm{A}=$ perpendicular to split-core surface; $\mathrm{B}=$ parallel to split-core surface; $\mathrm{C}=$ axial. 
Table 13. Thermal conductivity, Site 701.

\begin{tabular}{|c|c|c|}
\hline $\begin{array}{c}\text { Sample } \\
\text { (cm) }\end{array}$ & $\begin{array}{l}\text { Depth } \\
\text { (mbsf) }\end{array}$ & $\begin{array}{l}\text { Thermal } \\
\text { conductivity } \\
(\mathrm{W} / \mathrm{m} / \mathrm{k})\end{array}$ \\
\hline \multicolumn{3}{|l|}{ Hole 701A: } \\
\hline $1 \mathrm{H}-2,100$ & 2.50 & 0.8400 \\
\hline $1 \mathrm{H}-3,100$ & 4.00 & 0.7820 \\
\hline $1 \mathrm{H}-4,100$ & 5.50 & 0.7640 \\
\hline $1 \mathrm{H}-5,100$ & 7.00 & 0.8760 \\
\hline $2 \mathrm{H}-1,100$ & 9.30 & 0.7930 \\
\hline $2 \mathrm{H}-2,100$ & 10.80 & 0.7740 \\
\hline $2 \mathrm{H}-3,100$ & 12.30 & 0.8420 \\
\hline $2 \mathrm{H}-4,100$ & 13.80 & 0.8970 \\
\hline $2 \mathrm{H}-5,100$ & 15.30 & 0.8770 \\
\hline $2 \mathrm{H}-6,100$ & 16.80 & 0.9660 \\
\hline $3 \mathrm{H}-1,100$ & 18.80 & 1.9180 \\
\hline $3 \mathrm{H}-2,100$ & 20.30 & 0.7950 \\
\hline $3 \mathrm{H}-3,100$ & 21.80 & 0.8220 \\
\hline $3 \mathrm{H}-4,100$ & 23.30 & 0.8450 \\
\hline $3 \mathrm{H}-5,100$ & 24.80 & 0.7830 \\
\hline $3 \mathrm{H}-6,100$ & 26.30 & 0.8660 \\
\hline $4 \mathrm{H}-2,100$ & 29.80 & 0.9240 \\
\hline $4 \mathrm{H}-3,100$ & 31.30 & 0.8680 \\
\hline $5 \mathrm{H}-1,100$ & 37.80 & 0.9530 \\
\hline $5 \mathrm{H}-2,100$ & 39.30 & 0.8780 \\
\hline $5 \mathrm{H}-3,100$ & 40.80 & 0.7530 \\
\hline $5 \mathrm{H}-4,100$ & 42.30 & 0.8100 \\
\hline $5 \mathrm{H}-5,100$ & 43.80 & 0.9610 \\
\hline $5 \mathrm{H}-6,100$ & 45.30 & 1.0050 \\
\hline $6 \mathrm{H}-2,100$ & 48.80 & 0.8170 \\
\hline $6 \mathrm{H}-3,100$ & 50.30 & 0.8020 \\
\hline $6 \mathrm{H}-4,100$ & 51.80 & 0.9130 \\
\hline $6 \mathrm{H}-5,100$ & 53.30 & 0.9090 \\
\hline $7 \mathrm{H}-1,100$ & 56.80 & 0.6420 \\
\hline $7 \mathrm{H}-2,100$ & 58.30 & 0.9230 \\
\hline $7 \mathrm{H}-3,100$ & 59.80 & 0.7580 \\
\hline $7 \mathrm{H}-4,100$ & 61.30 & 0.6110 \\
\hline $8 \mathrm{H}-1,100$ & 66.30 & 1.0010 \\
\hline $8 \mathrm{H}-2,100$ & 67.80 & 0.9620 \\
\hline $8 \mathrm{H}-3,100$ & 69.30 & 0.9370 \\
\hline $8 \mathrm{H}-4,100$ & 70.80 & 0.9640 \\
\hline $8 \mathrm{H}-5,100$ & 72.30 & 0.9430 \\
\hline $8 \mathrm{H}-6,100$ & 73.80 & 0.9650 \\
\hline
\end{tabular}

Hole 701B:

$\begin{array}{lrl}1 \mathrm{H}-1,100 & 71.00 & 0.9560 \\ 1 \mathrm{H}-2,100 & 72.50 & 0.8950 \\ 1 \mathrm{H}-3,100 & 74.00 & 0.8500 \\ 1 \mathrm{H}-4,100 & 75.50 & 0.8930 \\ 2 \mathrm{H}-1,100 & 80.50 & 0.9040 \\ 2 \mathrm{H}-2,100 & 82.00 & 0.9090 \\ 2 \mathrm{H}-3,100 & 83.50 & 0.9000 \\ 2 \mathrm{H}-4,100 & 85.00 & 0.9630 \\ 3 \mathrm{H}-1,100 & 90.00 & 0.9220 \\ 3 \mathrm{H}-2,100 & 91.50 & 0.8690 \\ 3 \mathrm{H}-3,100 & 93.00 & 0.8770 \\ 3 \mathrm{H}-4,100 & 94.50 & 0.8730 \\ 4 \mathrm{H}-1,100 & 99.50 & 0.8840 \\ 4 \mathrm{H}-2,100 & 101.00 & 0.8880 \\ 4 \mathrm{H}-3,100 & 102.50 & 0.8020 \\ 5 \mathrm{H}-1,100 & 109.00 & 1.0040 \\ 5 \mathrm{H}-2,100 & 110.50 & 0.8950 \\ 5 \mathrm{H}-3,100 & 112.00 & 0.9920 \\ 5 \mathrm{H}-4,100 & 113.50 & 1.0340 \\ 6 \mathrm{H}-1,100 & 118.50 & 0.9750 \\ 6 \mathrm{H}-2,100 & 120.00 & 0.9230 \\ 6 \mathrm{H}-3,100 & 121.50 & 0.9790 \\ 6 \mathrm{H}-4,100 & 123.00 & 1.0470 \\ 7 \mathrm{H}-1,100 & 128.00 & 1.0650 \\ 7 \mathrm{H}-2,100 & 129.50 & 0.9450 \\ 7 \mathrm{H}-3,100 & 131.00 & 1.0200 \\ 7 \mathrm{H}-5,100 & 134.00 & 1.0720 \\ 8 \mathrm{H}-1,100 & 137.50 & 1.0470 \\ 8 \mathrm{H}-2,100 & 139.00 & 0.9790 \\ 8 \mathrm{H}-2,100 & 139.00 & 0.9790 \\ 8 \mathrm{H}-3,100 & 140.50 & 1.0810 \\ 8 \mathrm{H}-4,100 & 142.00 & 1.0730 \\ 9 \mathrm{H}-1,100 & 147.00 & 0.8620 \\ 9 \mathrm{H}-5,100 & 150.50 & 0.8180\end{array}$

Table 13 (continued).

\begin{tabular}{ccc}
\hline $\begin{array}{c}\text { Sample } \\
\text { (cm) }\end{array}$ & $\begin{array}{c}\text { Depth } \\
\text { (mbsf) }\end{array}$ & $\begin{array}{c}\text { Thermal } \\
\text { conductivity } \\
\text { (W/m/k) }\end{array}$ \\
\hline Hole 701B (Cont.): & & \\
& & \\
14X-1, 100 & 194.50 & 0.9480 \\
14X-2, 100 & 196.00 & 0.9120 \\
14X-3, 100 & 197.50 & 0.8870 \\
14X-4, 100 & 199.00 & 0.9070
\end{tabular}

Hole 701C:

\begin{tabular}{|c|c|c|}
\hline $1 \mathrm{H}-1,100$ & 1.00 & 0.8880 \\
\hline $1 \mathrm{H}-2,100$ & 2.50 & 0.8710 \\
\hline $1 \mathrm{H}-3,100$ & 4.00 & 0.8890 \\
\hline $1 \mathrm{H}-4,100$ & 5.50 & 0.9490 \\
\hline $2 \mathrm{H}-3,100$ & 10.30 & 0.8580 \\
\hline $2 \mathrm{H}-5,100$ & 13.30 & 0.8260 \\
\hline $3 \mathrm{H}-2,100$ & 18.30 & 0.8850 \\
\hline $3 \mathrm{H}-5,100$ & 22.80 & 0.9470 \\
\hline $4 \mathrm{H}-3,100$ & 29.30 & 0.9220 \\
\hline $4 \mathrm{H}-6,100$ & 33.80 & 0.9160 \\
\hline $5 \mathrm{H}-2,100$ & 37.30 & 0.6880 \\
\hline $5 \mathrm{H}-5,100$ & 41.80 & 1.1330 \\
\hline $6 \mathrm{H}-2,100$ & 46.80 & 0.7910 \\
\hline $6 \mathrm{H}-5,100$ & 51.30 & 0.8470 \\
\hline $7 \mathrm{H}-4,100$ & 59.30 & 0.8850 \\
\hline $8 \mathrm{H}-3,95$ & 67.25 & 0.9370 \\
\hline $10 \mathrm{H}-3,100$ & 86.30 & 0.8920 \\
\hline $11 \mathrm{H}-2,100$ & 94.30 & 0.8260 \\
\hline $11 \mathrm{H}-3,100$ & 95.80 & 0.8900 \\
\hline $11 \mathrm{H}-4,100$ & 97.30 & 0.8830 \\
\hline $11 \mathrm{H}-5,100$ & 98.80 & 0.8240 \\
\hline $12 \mathrm{H}-2,100$ & 103.80 & 0.9110 \\
\hline $12 \mathrm{H}-3,100$ & 105.30 & 0.7560 \\
\hline $13 \mathrm{H}-2,100$ & 113.30 & 0.8300 \\
\hline $13 \mathrm{H}-3,100$ & 114.80 & 0.8530 \\
\hline $13 \mathrm{H}-4,100$ & 116.30 & 0.9780 \\
\hline $13 \mathrm{H}-5,100$ & 117.80 & 1.0650 \\
\hline $14 \mathrm{H}-1,100$ & 121.30 & 0.7350 \\
\hline $14 \mathrm{H}-2,100$ & 122.80 & 0.9870 \\
\hline $14 \mathrm{H}-3,100$ & 124.30 & 0.9560 \\
\hline $14 \mathrm{H}-4,100$ & 125.80 & 0.9300 \\
\hline $15 \mathrm{H}-2,100$ & 132.30 & 1.0310 \\
\hline $15 \mathrm{H}-3,100$ & 133.80 & 1.0000 \\
\hline $15 \mathrm{H}-4,100$ & 135.30 & 1.0780 \\
\hline $16 \mathrm{H}-3,100$ & 143.30 & 1.0470 \\
\hline $17 \mathrm{H}-1,100$ & 149.80 & 0.9370 \\
\hline $17 \mathrm{H}-2,100$ & 151.30 & 0.8550 \\
\hline $17 \mathrm{H}-4,100$ & 153.78 & 0.9220 \\
\hline $17 \mathrm{H}-6,100$ & 156.78 & 0.9500 \\
\hline $18 \mathrm{H}-2,90$ & 160.70 & 0.8100 \\
\hline $19 \mathrm{H}-1,100$ & 168.80 & 0.8850 \\
\hline $20 \mathrm{H}-2,100$ & 179.80 & 0.9800 \\
\hline $20 \mathrm{H}-3,100$ & 181.30 & 0.9650 \\
\hline $20 \mathrm{H}-4,100$ & 182.80 & 1.0680 \\
\hline $20 \mathrm{H}-5,100$ & 184.30 & 1.1100 \\
\hline $21 \mathrm{H}-1,100$ & 187.80 & 0.9000 \\
\hline $21 \mathrm{H}-2,100$ & 189.30 & 0.8860 \\
\hline $21 \mathrm{H}-3,70$ & 190.50 & 0.9280 \\
\hline $22 \mathrm{H}-2,100$ & 198.80 & 0.9050 \\
\hline $22 \mathrm{H}-3,100$ & 200.30 & 0.8820 \\
\hline $22 \mathrm{H}-4,100$ & 201.80 & 0.9090 \\
\hline $22 \mathrm{H}-5,100$ & 203.30 & 1.1420 \\
\hline $23 \mathrm{H}-2,100$ & 208.30 & 1.0130 \\
\hline $23 \mathrm{H}-3,100$ & 209.80 & 0.8600 \\
\hline $23 \mathrm{H}-4,100$ & 211.30 & 0.8990 \\
\hline $23 \mathrm{H}-5,100$ & 212.80 & 0.9490 \\
\hline $24 \mathrm{H}-1,100$ & 216.30 & 0.8500 \\
\hline $24 \mathrm{H}-2,100$ & 217.80 & 0.8640 \\
\hline $24 \mathrm{H}-3,100$ & 219.30 & 0.8660 \\
\hline $24 \mathrm{H}-4,100$ & 220.80 & 0.9490 \\
\hline $25 X-2,100$ & 227.30 & 0.8820 \\
\hline $25 \times-3,90$ & 228.70 & 0.8810 \\
\hline $27 X-2,100$ & 246.30 & 1.0600 \\
\hline $27 \mathrm{X}-3,80$ & 247.60 & 0.9810 \\
\hline $31 X-1,100$ & 282.80 & 0.9230 \\
\hline $31 \times-2,100$ & 284.30 & 0.9270 \\
\hline $31 X-3,100$ & 285.80 & 0.8630 \\
\hline $31 X-4,100$ & 287.30 & 0.8990 \\
\hline
\end{tabular}


Table 13 (continued).

\begin{tabular}{|c|c|c|}
\hline $\begin{array}{c}\text { Sample } \\
\text { (cm) }\end{array}$ & $\begin{array}{l}\text { Depth } \\
\text { (mbsf) }\end{array}$ & $\begin{array}{l}\text { Thermal } \\
\text { conductivity } \\
(\mathrm{W} / \mathrm{m} / \mathrm{k})\end{array}$ \\
\hline \multicolumn{3}{|c|}{ Hole $701 \mathrm{C}$ (Cont.): } \\
\hline $32 X-2,100$ & 293.80 & 0.8790 \\
\hline $32 X-3,100$ & 295.30 & 0.8340 \\
\hline $32 \times-4,100$ & 296.80 & 0.8930 \\
\hline $32 X-5,100$ & 298.30 & 0.9830 \\
\hline $34 X-2,100$ & 312.80 & 0.9040 \\
\hline $34 X-3,100$ & 314.30 & 0.8810 \\
\hline $34 X-4,100$ & 315.80 & 0.8560 \\
\hline $34 X-5,100$ & 317.30 & 0.9280 \\
\hline $35 X-3,100$ & 322.49 & 0.9380 \\
\hline $35 X-4,100$ & 323.99 & 0.8640 \\
\hline $35 X-5,100$ & 325.49 & 0.8900 \\
\hline $35 X-6,100$ & 326.99 & 0.9520 \\
\hline $36 \times-1,100$ & 330.30 & 0.9090 \\
\hline $37 X-1,100$ & 339.80 & 0.8600 \\
\hline $37 X-2,100$ & 341.30 & 0.9100 \\
\hline $37 X-4,100$ & 344.30 & 0.8860 \\
\hline $42 X-1,100$ & 387.30 & 1.2130 \\
\hline $42 X-2,20$ & 388.00 & 1.1030 \\
\hline $43 \mathrm{X}-1,100$ & 396.80 & 0.9370 \\
\hline $43 X-2,100$ & 398.30 & 0.9010 \\
\hline $43 X-3,100$ & 399.80 & 0.9070 \\
\hline $43 X-4,100$ & 401.30 & 1.0360 \\
\hline $44 X-1,100$ & 406.30 & 0.9340 \\
\hline $44 X-2,100$ & 407.80 & 0.9870 \\
\hline $44 X-3,100$ & 409.30 & 0.9140 \\
\hline $44 X-4,100$ & 410.80 & 1.1390 \\
\hline $45 X-1,100$ & 415.80 & 1.0160 \\
\hline $45 X-2,100$ & 417.30 & 0.9480 \\
\hline $45 X-3,100$ & 418.80 & 0.9660 \\
\hline $45 X-4,100$ & 420.30 & 0.9240 \\
\hline
\end{tabular}

Lithostratigraphic Subunit IA

(0-74.8 mbsf, Hole 701A; upper Pliocene to Quaternary)

\begin{tabular}{lllll}
\hline & & Mean & Minimum & Maximum \\
\hline Wet-bulk density & $\left(\mathrm{g} / \mathrm{cm}^{3}\right)$ & 1.38 & 1.22 & 2.17 \\
Dry-bulk density & $\left(\mathrm{g} / \mathrm{cm}^{3}\right)$ & 0.57 & 0.28 & 1.57 \\
Grain density & $\left(\mathrm{g} / \mathrm{cm}^{3}\right)$ & 2.45 & 2.00 & 2.77 \\
Porosity & $(\%)$ & 79.67 & 51.35 & 91.53 \\
Water content & $(\%)$ & 60.73 & 26.73 & 76.77 \\
Carbonate content & $(\%)$ & 0.94 & 0.00 & 10.76 \\
Thermal conductivity & $(\mathrm{W} / \mathrm{m} / \mathrm{K})$ & 0.8879 & 0.6110 & 1.9180 \\
Shear strength & $(\mathrm{kPa})$ & 31.71 & 4.7 & 116.4
\end{tabular}

(70.0-147.5 mbsf, Hole 701B; upper Miocene to lower Pliocene)

\begin{tabular}{llccc}
\hline & & Mean & Minimum & Maximum \\
\hline Wet-bulk density & $\left(\mathrm{g} / \mathrm{cm}^{3}\right)$ & 1.40 & 1.28 & 1.81 \\
Dry-bulk density & $\left(\mathrm{g} / \mathrm{cm}^{3}\right)$ & 0.58 & 0.37 & 1.16 \\
Grain density & $\left(\mathrm{g} / \mathrm{cm}^{3}\right)$ & 2.72 & 2.24 & 3.70 \\
Porosity & $(\%)$ & 80.82 & 63.19 & 87.57 \\
Water content & $(\%)$ & 59.57 & 49.31 & 70.73 \\
Carbonate content & $(\%)$ & 0.00 & 0.00 & 0.00 \\
Thermal conductivity & $(\mathrm{W} / \mathrm{m} / \mathrm{K})$ & 0.9607 & 0.8020 & 1.0810 \\
Shear strength & $(\mathrm{kPa})$ & 69.46 & 9.3 & 123.3 \\
$P$-wave velocity & $(\mathrm{m} / \mathrm{s})$ & 1536 & 1468 & 1560
\end{tabular}

(0-145.5 mbsf, Hole 701C; upper Miocene to Quaternary)

\begin{tabular}{llccc}
\hline & & Mean & Minimum & Maximum \\
\hline Wet-bulk density & $\left(\mathrm{g} / \mathrm{cm}^{3}\right)$ & 1.39 & 1.22 & 1.52 \\
Dry-bulk density & $\left(\mathrm{g} / \mathrm{cm}^{3}\right)$ & 0.53 & 0.31 & 0.73 \\
Grain density & $\left(\mathrm{g} / \mathrm{cm}^{3}\right)$ & 2.70 & 2.25 & 3.26 \\
Porosity & $(\%)$ & 83.58 & 73.95 & 91.44 \\
Water content & $(\%)$ & 61.97 & 50.92 & 74.92 \\
Carbonate content & $(\%)$ & 0.74 & 0.08 & 10.76 \\
Thermal conductivity & $(\mathrm{W} / \mathrm{m} / \mathrm{K})$ & 0.9058 & 0.6880 & 1.1330 \\
Shear strength & $(\mathrm{kPa})$ & 58.38 & 5.8 & 146.6 \\
$P$-wave velocity & $(\mathrm{m} / \mathrm{s})$ & 1553 & 1439 & 1605
\end{tabular}

Table 14. Vane shear strength, Site 701.

\begin{tabular}{ccc}
\hline $\begin{array}{c}\text { Sample } \\
(\mathrm{cm})\end{array}$ & $\begin{array}{c}\text { Depth } \\
(\mathrm{mbs})\end{array}$ & $\begin{array}{c}\text { Shear } \\
\text { strength } \\
(\mathrm{kPa})\end{array}$ \\
\hline
\end{tabular}

Hole 701A:

$\begin{array}{lrr}1 \mathrm{H}-2,100-102 & 2.50 & 4.7 \\ 1 \mathrm{H}-3,100-102 & 4.00 & 4.7 \\ 1 \mathrm{H}-4,95-97 & 5.45 & 27.9 \\ 1 \mathrm{H}-5,105-107 & 7.05 & 30.3 \\ 2 \mathrm{H}-2,100-102 & 10.80 & 16.3 \\ 2 \mathrm{H}-4,100-102 & 13.80 & 18.2 \\ 2 \mathrm{H}-6,100-102 & 16.80 & 14.0 \\ 2 \mathrm{H}-6,100-102 & 16.80 & 14.0 \\ 4 \mathrm{H}-3,100-102 & 31.30 & 7.4 \\ 5 \mathrm{H}-2,100-102 & 39.30 & 7.0 \\ 5 \mathrm{H}-3,73-75 & 40.53 & 54.7 \\ 5 \mathrm{H}-5,73-75 & 43.53 & 40.0 \\ 6 \mathrm{H}-6,100-102 & 54.80 & 116.4 \\ 7 \mathrm{H}-4,100-102 & 61.30 & 30.3 \\ 8 \mathrm{H}-1,100-102 & 66.30 & 31.9 \\ 8 \mathrm{H}-4,100-102 & 70.80 & 89.6\end{array}$

Hole 701B:

$1 \mathrm{H}-1,100-102$

$1 \mathrm{H}-2,100-102$

$1 \mathrm{H}-3,100-102$

$1 \mathrm{H}-4,100-102$

$1 \mathrm{H}-5,100-102$

$2 \mathrm{H}-1,100-102$

$2 \mathrm{H}-2,100-102$

$2 \mathrm{H}-3,100-102$

$2 \mathrm{H}-4,100-102$

$3 \mathrm{H}-1,100-102$

$3 \mathrm{H}-2,100-102$

$3 \mathrm{H}-3,100-102$

$3 \mathrm{H}-4,100-102$

$3 \mathrm{H}-5,100-102$

$4 \mathrm{H}-3,100-102$

$4 \mathrm{H}-4,98-100$

$4 \mathrm{H}-5,100-102$

$4 \mathrm{H}-6,100-102$

$5 \mathrm{H}-1,100-102$

$5 \mathrm{H}-2,100-102$

$5 \mathrm{H}-3,100-102$

$5 \mathrm{H}-4,100-102$

5H-5, 100-102

$5 \mathrm{H}-6,100-102$

$6 \mathrm{H}-2,100-102$

$6 \mathrm{H}-4,100-102$

$7 \mathrm{H}-1,100-102$

$7 \mathrm{H}-3,50-52$

$7 \mathrm{H}-5,100-102$

$8 \mathrm{H}-1,100-102$

$8 \mathrm{H}-3,100-102$

$8 \mathrm{H}-5,100-102$

$13 \mathrm{X}-3,100-102$

$14 \mathrm{X}-2,100-102$

$14 \mathrm{X}-3,100-102$

$14 \mathrm{X}-4,100-102$

$14 X-5,105-107$

71.00

55.9

$72.50 \quad 86.1$

$74.00 \quad 74.5$

$75.50 \quad 123.3$

$77.00 \quad 95.4$

$80.50 \quad 18.6$

$82.00 \quad 20.9$

$83.50 \quad 16.3$

$85.00 \quad 9.3$

$90.00 \quad 53.5$

$91.50 \quad 58.2$

$93.00 \quad 55.9$

$94.50 \quad 55.9$

$96.00 \quad 76.8$

$102.50 \quad 30.3$

$103.98 \quad 81.4$

$105.50 \quad 88.4$

$107.00 \quad 93.1$

$109.00 \quad 74.5$

$110.50 \quad 74.5$

$112.00 \quad 60.5$

$113.50 \quad 109.4$

$115.00 \quad 107.0$

$116.50 \quad 97.7$

$120.00 \quad 86.1$

$123.00 \quad 116.4$

$128.00 \quad 41.4$

$130.50 \quad 39.6$

$134.00 \quad 18.6$

$137.50 \quad 83.8$

$140.50 \quad 93.1$

$143.50 \quad 112.9$

$188.00 \quad 123.3$

$196.00 \quad 104.7$

$197.50 \quad 74.5$

$199.00 \quad 69.8$

Hole 701C:

$\begin{array}{lrr}1 \mathrm{H}-1,100-102 & 1.00 & 14.0 \\ 1 \mathrm{H}-2,100-102 & 2.50 & 20.9 \\ 1 \mathrm{H}-3,100-102 & 4.00 & 37.2 \\ 1 \mathrm{H}-4,100-102 & 5.50 & 32.6 \\ 1 \mathrm{H}-5,100-102 & 7.00 & 20.9 \\ 2 \mathrm{H}-3,130-132 & 10.60 & 25.6 \\ 3 \mathrm{H}-2,100-102 & 18.30 & 32.6 \\ 3 \mathrm{H}-5,100-102 & 22.80 & 15.8 \\ 4 \mathrm{H}-2,100-102 & 27.80 & 5.8 \\ 4 \mathrm{H}-4,100-102 & 30.80 & 39.6 \\ 5 \mathrm{H}-4,120-122 & 40.50 & 30.3 \\ 6 \mathrm{H}-2,80-82 & 46.60 & 14.0 \\ 6 \mathrm{H}-4,100-102 & 49.80 & 20.9 \\ 7 \mathrm{H}-1,95-97 & 54.75 & 27.9 \\ 7 \mathrm{H}-2,95-97 & 56.25 & 72.1\end{array}$


Table 14 (continued).

\begin{tabular}{|c|c|c|}
\hline $\begin{array}{c}\text { Sample } \\
(\mathrm{cm})\end{array}$ & $\begin{array}{l}\text { Depth } \\
\text { (mbsf) }\end{array}$ & $\begin{array}{c}\text { Shear } \\
\text { strength } \\
\text { (kPa) }\end{array}$ \\
\hline \multicolumn{3}{|l|}{ Hole 701C (cont.): } \\
\hline $1 \mathrm{H}-2,100-102$ & 2.50 & 4.7 \\
\hline $8 \mathrm{H}-3,100-102$ & 67.30 & 59.3 \\
\hline $9 \mathrm{H}-1,100-102$ & 73.80 & 25.6 \\
\hline $9 \mathrm{H}-4,100-102$ & 78.30 & 65.2 \\
\hline $10 \mathrm{H}-4,100-102$ & 87.80 & 76.8 \\
\hline $10 \mathrm{H}-5,100-102$ & 89.30 & 93.1 \\
\hline $11 \mathrm{H}-4,100-102$ & 97.30 & 41.9 \\
\hline $11 \mathrm{H}-5,105-107$ & 98.85 & 32.6 \\
\hline $11 \mathrm{H}-6,125-127$ & 100.55 & 37.2 \\
\hline $13 \mathrm{H}-1,100-102$ & 111.80 & 25.6 \\
\hline $13 \mathrm{H}-3,100-102$ & 114.80 & 111.7 \\
\hline $13 \mathrm{H}-4,100-102$ & 116.30 & 121.0 \\
\hline $13 \mathrm{H}-5,100-102$ & 117.80 & 100.1 \\
\hline $14 \mathrm{H}-2,100-102$ & 122.80 & 81.4 \\
\hline $14 \mathrm{H}-3,100-102$ & 124.30 & 97.7 \\
\hline $14 \mathrm{H}-4,107-109$ & 125.87 & 118.7 \\
\hline $14 \mathrm{H}-5,107-109$ & 127.37 & 146.6 \\
\hline $15 \mathrm{H}-2,100-102$ & 132.30 & 84.9 \\
\hline $15 \mathrm{H}-4,100-102$ & 135.30 & 109.4 \\
\hline $16 \mathrm{H}-2,100-102$ & 141.80 & 111.2 \\
\hline $16 \mathrm{H}-4,100-102$ & 144.80 & 93.1 \\
\hline $16 \mathrm{H}-6,100-102$ & 147.80 & 172.2 \\
\hline $17 \mathrm{H}-1,100-102$ & 149.80 & 180.4 \\
\hline $17 \mathrm{H}-2,100-102$ & 151.30 & 112.9 \\
\hline $17 \mathrm{H}-4,100-102$ & 153.78 & 275.8 \\
\hline $17 \mathrm{H}-6,100-102$ & 156.78 & 169.9 \\
\hline $18 \mathrm{H}-2,90-92$ & 160.70 & 65.2 \\
\hline $19 \mathrm{H}-1,100-102$ & 168.80 & 139.6 \\
\hline $20 \mathrm{H}-1,100-102$ & 178.30 & 128.0 \\
\hline $20 \mathrm{H}-3,100-102$ & 181.30 & 199.0 \\
\hline $20 \mathrm{H}-5,100-102$ & 184.30 & 139.6 \\
\hline $21 \mathrm{H}-1,100-102$ & 187.80 & 84.5 \\
\hline $21 \mathrm{H}-2,100-102$ & 189.30 & 134.5 \\
\hline $22 \mathrm{H}-3,100-102$ & 200.30 & 155.9 \\
\hline $22 \mathrm{H}-4,100-102$ & 201.80 & 162.9 \\
\hline $22 \mathrm{H}-5,100-102$ & 203.30 & 204.8 \\
\hline $22 \mathrm{H}-6,108-110$ & 204.88 & 197.8 \\
\hline $23 \mathrm{H}-1,100-102$ & 206.80 & 153.6 \\
\hline $23 \mathrm{H}-2,100-102$ & 208.30 & 179.2 \\
\hline $23 \mathrm{H}-3,100-102$ & 209.80 & 276.9 \\
\hline $23 \mathrm{H}-4,100-102$ & 211.30 & 74.5 \\
\hline $23 \mathrm{H}-5,8-10$ & 211.88 & 223.4 \\
\hline $24 \mathrm{H}-1,100-102$ & 216.30 & 155.9 \\
\hline $24 \mathrm{H}-2,100-102$ & 217.80 & 144.3 \\
\hline $24 \mathrm{H}-3,100-102$ & 219.30 & 144.3 \\
\hline $24 \mathrm{H}-4,100-102$ & 220.80 & 179.2 \\
\hline $24 \mathrm{H}-5,100-102$ & 222.30 & 186.2 \\
\hline $24 \mathrm{H}-6,100-102$ & 223.80 & 179.2 \\
\hline $25 \mathrm{X}-2,100-102$ & 227.30 & 107.0 \\
\hline $25 X-3,100-102$ & 228.80 & 72.1 \\
\hline $25 \times-4,100-102$ & 230.30 & 95.4 \\
\hline $26 \mathrm{X}-1,100-102$ & 235.30 & 123.3 \\
\hline $27 X-2,100-102$ & 246.30 & 130.3 \\
\hline $29 \times-4,100-102$ & 268.30 & 46.5 \\
\hline
\end{tabular}

Subunit IB (147.5-174.76 mbsf, Hole 701B; 145.5-160.9 mbsf, Hole 701C) is a single-species diatom ooze composed entirely of Bruniopsis mirabilis (see "Lithostratigraphy" and "Biostratigraphy" sections). The highly siliceous nature of this subunit has a notable effect on all of the physical properties. The grain density in particular decreases markedly, and the porosity and water content increase, giving rise to a distinct minimum in the wetbulk density (Fig. 27). However, the diatom valves form a strong interlocking matrix, which has a high shear strength (Fig. 27).

Subunit IB

(147.5-174.76 mbsf, Hole 701B; upper Miocene)

\begin{tabular}{|c|c|c|c|c|}
\hline & & Mean & Minimum & Maximum \\
\hline Wet-bulk density & $\left(\mathrm{g} / \mathrm{cm}^{3}\right)$ & 1.33 & 1.31 & 1.34 \\
\hline Dry-bulk density & $\left(\mathrm{g} / \mathrm{cm}^{3}\right)$ & 0.37 & 0.34 & 0.39 \\
\hline Porosity & $(\%)$ & 94.01 & 92.77 & 95.25 \\
\hline Water content & $(\%)$ & 72.57 & 70.83 & 74.31 \\
\hline Carbonate content & $(\%)$ & 0.83 & 0.83 & 0.83 \\
\hline Thermal conductivity & $(\mathrm{W} / \mathrm{m} / \mathrm{K})$ & 0.8180 & 0.8180 & 0.8180 \\
\hline Shear strength & $(\mathrm{kPa})$ & 92.14 & 69.8 & 123.3 \\
\hline
\end{tabular}

(145.5-160.9 mbsf, Hole 701C; upper Miocene)

\begin{tabular}{llccc}
\hline & & Mean & Minimum & Maximum \\
\hline Wet-bulk density & $\left(\mathrm{g} / \mathrm{cm}^{3}\right)$ & 1.25 & 1.23 & 1.27 \\
Dry-bulk density & $\left(\mathrm{g} / \mathrm{cm}^{3}\right)$ & 0.34 & 0.32 & 0.35 \\
Grain density & $\left(\mathrm{g} / \mathrm{cm}^{3}\right)$ & 2.29 & 2.14 & 2.44 \\
Porosity & $(\%)$ & 89.19 & 88.11 & 90.09 \\
Water content & $(\%)$ & 72.83 & 71.79 & 74.40 \\
Carbonate content & $(\%)$ & 0.76 & 0.08 & 5.50 \\
Thermal conductivity & $(\mathrm{W} / \mathrm{m} / \mathrm{K})$ & 0.8948 & 0.8100 & 0.9500 \\
Shear strength & $(\mathrm{kPa})$ & 162.73 & 65.2 & 275.9 \\
P-wave velocity & $(\mathrm{m} / \mathrm{s})$ & 1560 & 1525 & 1616
\end{tabular}

Subunit IC (174.76-183.71 mbsf, Hole 701B; 160.9-167.96 mbsf, Hole 701C) is a sand/gravel layer that, because of its nature, could not be sampled properly for physical properties.

Subunit ID (183.71-203.0 mbsf, Hole 701B; 167.96-243.8 mbsf, Hole 701C) is a clay-bearing diatom ooze, and in comparison to the Bruniopsis ooze of Subunit IB, has higher bulk and grain densities, higher velocity, and lower porosity and water content. The physical properties, especially the grain density, have greater variability because of the changing ratio of terrigenous and siliceous components.

Subunit ID

(183.71-203.0 mbsf, Hole 701B; middle to upper Miocene)

\begin{tabular}{llccc}
\hline & & Mean & Minimum & Maximum \\
\hline Wet-bulk density & $\left(\mathrm{g} / \mathrm{cm}^{3}\right)$ & 1.36 & 1.31 & 1.37 \\
Dry-bulk density & $\left(\mathrm{g} / \mathrm{cm}^{3}\right)$ & 0.52 & 0.46 & 0.55 \\
Grain density & $\left(\mathrm{g} / \mathrm{cm}^{3}\right)$ & 2.55 & 2.35 & 2.84 \\
Porosity & $(\%)$ & 82.03 & 78.98 & 83.43 \\
Water content & $(\%)$ & 62.03 & 60.12 & 65.03 \\
Carbonate content & $(\%)$ & 0.83 & 0.83 & 0.83 \\
Thermal conductivity & $(\mathrm{W} / \mathrm{m} / \mathrm{K})$ & 0.9135 & 0.8870 & 0.9480 \\
$P$-wave velocity & $(\mathrm{m} / \mathrm{s})$ & 1550 & 1547 & 1552
\end{tabular}

(167.96-243.8 mbsf, Hole 701C; middle to upper Miocene)

\begin{tabular}{llccc}
\hline & & Mean & Minimum & Maximum \\
\hline Wet-bulk density & $\left(\mathrm{g} / \mathrm{cm}^{3}\right)$ & 1.42 & 1.28 & 1.51 \\
Dry-bulk density & $\left(\mathrm{g} / \mathrm{cm}^{3}\right)$ & 0.59 & 0.41 & 1.10 \\
Grain density & $\left(\mathrm{g} / \mathrm{cm}^{3}\right)$ & 2.63 & 2.25 & 3.13 \\
Porosity & $(\%)$ & 81.52 & 66.31 & 90.16 \\
Water content & $(\%)$ & 59.87 & 38.19 & 67.89 \\
Carbonate content & $(\%)$ & 0.53 & 0.08 & 3.25 \\
Thermal conductivity & $(\mathrm{W} / \mathrm{m} / \mathrm{K})$ & 0.9351 & 0.8820 & 1.1420 \\
Shear strength & $(\mathrm{kPa})$ & 153.64 & 72.1 & 276.9 \\
$P$-wave velocity & $(\mathrm{m} / \mathrm{s})$ & 1572 & 1544 & 1598
\end{tabular}

Lithostratigraphic Unit II (243.8-395.15 mbsf, Hole 701C) is a siliceous clay/mud layer. Just as in Subunit ID, the varying 


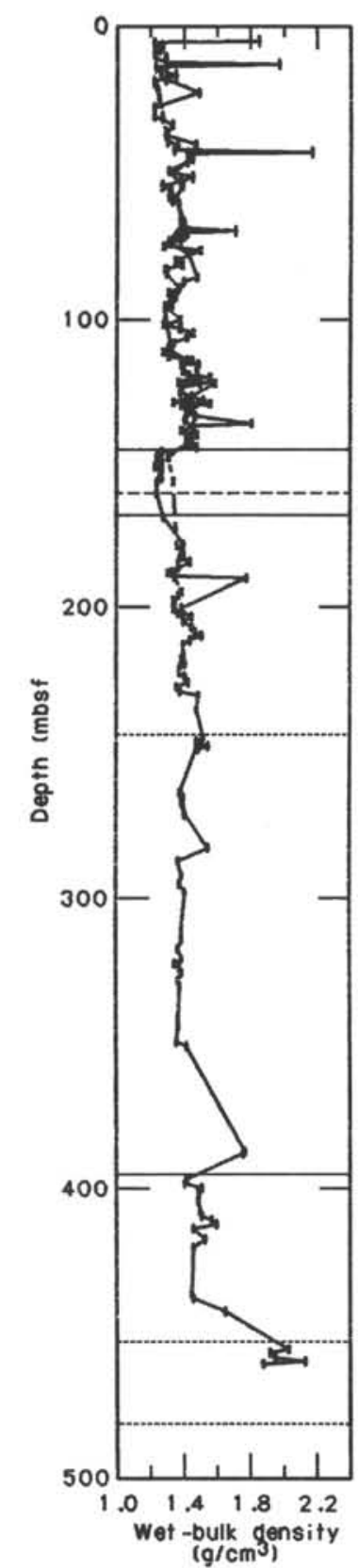

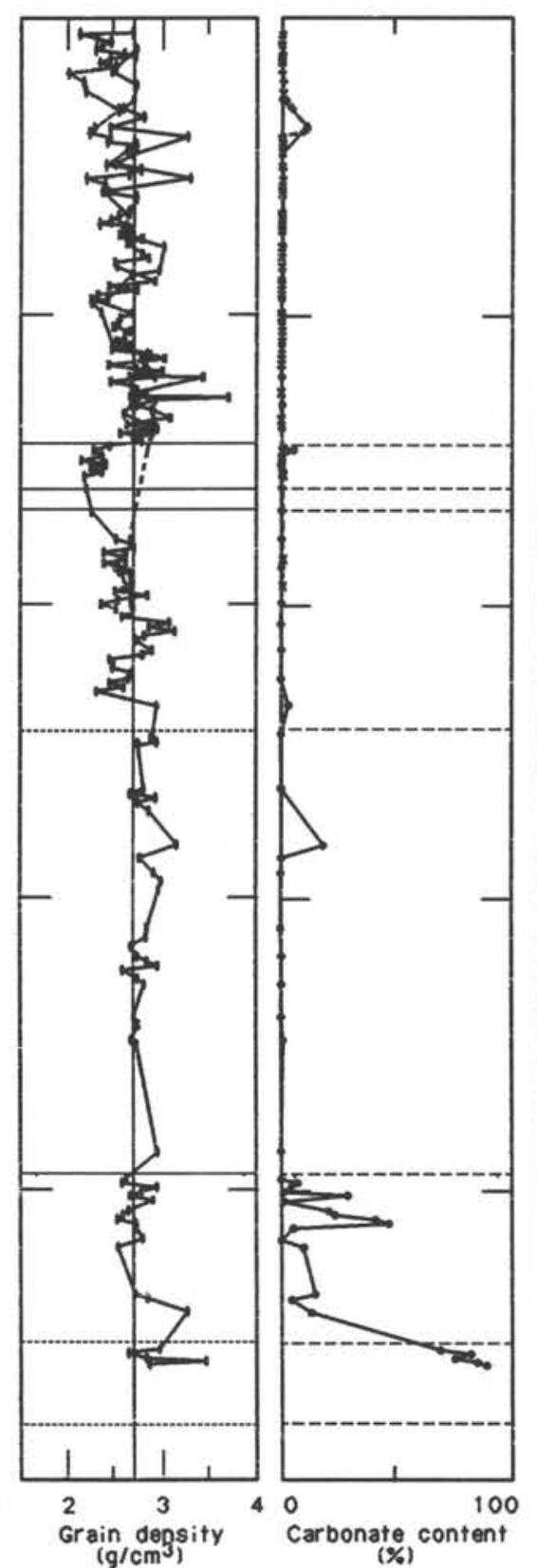

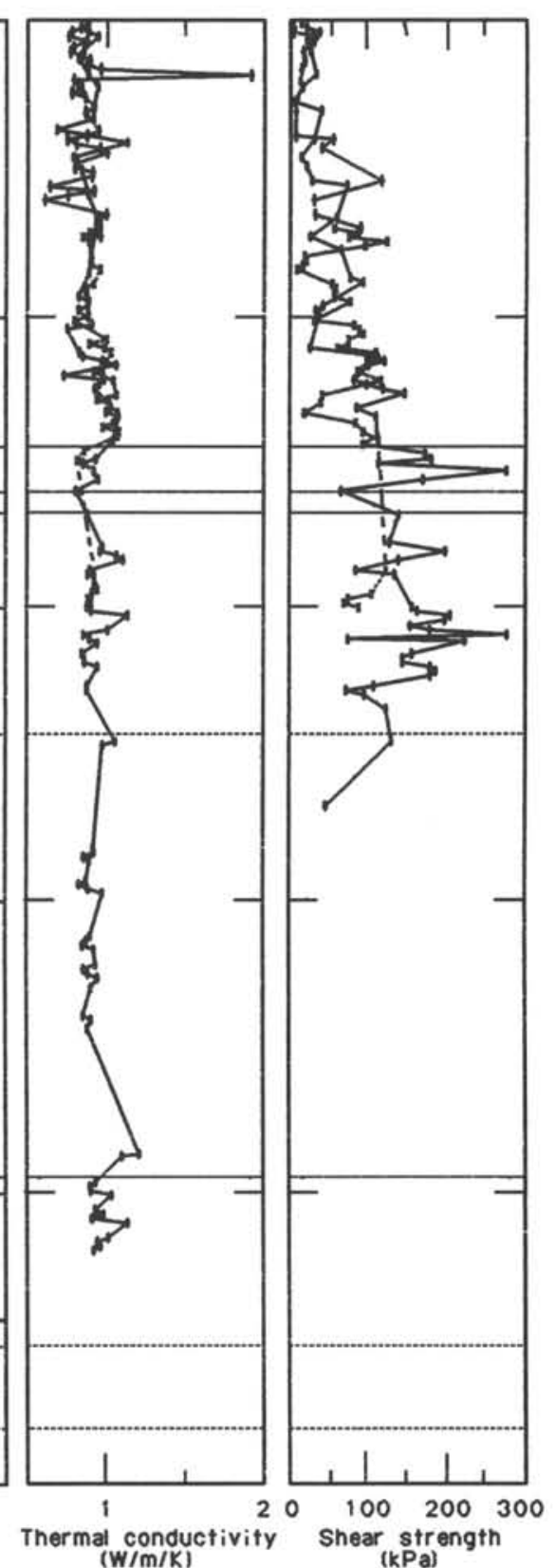

$(W / \mathrm{m} / \mathrm{K}$ )
Figure 27. Wet-bulk density, porosity, water content, grain density, carbonate content, $P$-wave velocity, thermal conductivity, and shear strength profiles for Site 701 . Data for Hole $701 \mathrm{~A}$ are designated by crosses $(+)$ and dashed lines, for Hole 701B by $x$ 's and dashed lines, and for Hole 701C by solid circles and solid lines. The boundaries between lithostratigraphic units are indicated by the long-dashed horizontal lines, and subunit boundaries are indicated by the short-dashed horizontal lines. 
terrigenous and siliceous contents give rise to variations in the physical properties. The largest changes are apparent in the grain density and the $P$-wave velocity (Fig. 27). The unit is divided into two subunits, based on the lack or presence of nannofossils. The differences between the subunits are displayed most prominently in the carbonate content (Fig. 27), which increases from a mean value of $1.93 \%$ in Subunit IIA to a mean value of $13.90 \%$ in Subunit IIB. The base of each subunit is distinguished by sharp increases in wet-bulk density, grain density, velocity, and thermal conductivity, and decreases in porosity and water content (Fig. 27).

Lithostratigraphic Unit II

(243.8-452.8 mbsf, Hole 701C; upper Eocene to middle Miocene)

\begin{tabular}{llccc}
\hline & & Mean & Minimum & Maximum \\
\hline Wet-bulk density & $\left(\mathrm{g} / \mathrm{cm}^{3}\right)$ & 1.45 & 1.36 & 1.77 \\
Dry-bulk density & $\left(\mathrm{g} / \mathrm{cm}^{3}\right)$ & 0.63 & 0.50 & 1.09 \\
Grain density & $\left(\mathrm{g} / \mathrm{cm}^{3}\right)$ & 2.79 & 2.57 & 3.26 \\
Porosity & $(\%)$ & 80.71 & 65.21 & 89.78 \\
Water content & $(\%)$ & 57.06 & 37.91 & 63.00 \\
Carbonate content & $(\%)$ & 9.02 & 0.08 & 46.70 \\
Thermal conductivity & $(\mathrm{W} / \mathrm{m} / \mathrm{K})$ & 0.9409 & 0.8340 & 1.2130 \\
Shear strength & $(\mathrm{kPa})$ & 88.4 & 46.5 & 130.3 \\
P-wave velocity & $(\mathrm{m} / \mathrm{s})$ & 1572 & 1441 & 1614 \\
& \multicolumn{2}{c}{ Subunit IIA } & \\
& & &
\end{tabular}

(243.8-395.15 mbsf, Hole 701C; lower-middle Miocene)

\begin{tabular}{llccc}
\hline & & Mean & Minimum & Maximum \\
\hline Wet-bulk density & $\left(\mathrm{g} / \mathrm{cm}^{3}\right)$ & 1.43 & 1.36 & 1.77 \\
Dry-bulk density & $\left(\mathrm{g} / \mathrm{cm}^{3}\right)$ & 0.61 & 0.50 & 1.09 \\
Grain density & $\left(\mathrm{g} / \mathrm{cm}^{3}\right)$ & 2.82 & 2.58 & 3.15 \\
Porosity & $(\%)$ & 80.79 & 65.21 & 84.79 \\
Water content & $(\%)$ & 58.10 & 37.91 & 62.88 \\
Carbonate content & $(\%)$ & 1.93 & 0.08 & 18.35 \\
Thermal conductivity & $(\mathrm{W} / \mathrm{m} / \mathrm{K})$ & 0.9277 & 0.8340 & 1.2130 \\
Shear strength & $(\mathrm{kPa})$ & 88.4 & 46.5 & 130.3 \\
$P$-wave velocity & $(\mathrm{m} / \mathrm{s})$ & 1566 & 1441 & 1614 \\
& \multicolumn{2}{c}{ Subunit IIB } & &
\end{tabular}

(395.15-452.8 mbsf, Hole 701C; upper Eocene to lower Oligocene)

\begin{tabular}{llccc}
\hline & & Mean & Minimum & Maximum \\
\hline Wet-bulk density & $\left(\mathrm{g} / \mathrm{cm}^{3}\right)$ & 1.50 & 1.41 & 1.65 \\
Dry-bulk density & $\left(\mathrm{g} / \mathrm{cm}^{3}\right)$ & 0.67 & 0.54 & 0.86 \\
Grain density & $\left(\mathrm{g} / \mathrm{cm}^{3}\right)$ & 2.74 & 2.57 & 3.26 \\
Porosity & $(\%)$ & 80.56 & 71.62 & 89.78 \\
Water content & $(\%)$ & 55.10 & 46.00 & 63.00 \\
Carbonate content & $(\%)$ & 13.90 & 0.17 & 46.70 \\
Thermal conductivity & $(\mathrm{W} / \mathrm{m} / \mathrm{K})$ & 0.9674 & 0.9010 & 1.1390 \\
$P$-wave velocity & $(\mathrm{m} / \mathrm{s})$ & 1589 & 1537 & 1614
\end{tabular}

Lithostratigraphic Unit III (452.8-481.3 mbsf, Hole 701C) is an indurated nannofossil chalk, with high carbonate content and low water content. The grain and wet-bulk densities are high, and the porosity and water content are considerably lower than in Unit II (siliceous clay/mud).

Lithostratigraphic Unit III (452.8-481.3 mbsf, Hole 701C; middle Eocene)

\begin{tabular}{llrrr}
\hline & & Mean & Minimum & Maximum \\
\hline Wet-bulk density & $\left(\mathrm{g} / \mathrm{cm}^{3}\right)$ & 1.98 & 1.88 & 2.13 \\
Dry-bulk density & $\left(\mathrm{g} / \mathrm{cm}^{3}\right)$ & 1.35 & 1.22 & 1.44 \\
Grain density & $\left(\mathrm{g} / \mathrm{cm}^{3}\right)$ & 2.95 & 2.64 & 3.46 \\
Porosity & $(\%)$ & 62.06 & 56.26 & 66.96 \\
Water content & $(\%)$ & 32.12 & 29.50 & 35.12 \\
Carbonate content & $(\%)$ & 80.12 & 69.06 & 89.07
\end{tabular}

The basal lithostratigraphic Unit IV (481.3 mbsf, Hole 701C) consists of an amygdaloidal olivine basalt, which was recovered only in the core catcher of Core 114-701C-52W. The $P$-wave velocity of this sample was measured, and the average Hamilton
Frame sonic velocity is $4545 \mathrm{~m} / \mathrm{s}$. By using the time-average equation (Wyllie et al., 1956), which is approximately valid for media with low porosities, such as the basalt, we may estimate a value for the porosity. Using an assumed velocity of $6000 \mathrm{~m} / \mathrm{s}$ for basalt of zero porosity, the estimated porosity for a velocity of $4545 \mathrm{~m} / \mathrm{s}$ is approximately $10 \%$, a value consistent with results obtained for the upper portions of oceanic crust elsewhere (e.g., Nobes et al., 1986; Becker, 1985).

\section{Hiatuses and Physical-Property Variations}

A number of hiatuses have been identified in the biostratigraphic record (see "Biostratigraphy" section). We examined the physical-property record in an attempt to determine what effects such hiatuses may have had on the physical properties of the sediments. The task was made more difficult because a number of the hiatuses are close to lithostratigraphic boundaries, where any variation resulting from a hiatus could be lost among the changes normally associated with a lithologic change. Nonetheless, based on our results, we see some confirmation in the physical-property record to support the presence of hiatuses in the sediment section.

Comparisons of physical properties across hiatuses are based on depths in Hole 701C, as indicated in the following. The range of the depths for each hiatus, the age of the missing sediment section, and the thickness of the missing section are given for each hiatus. The thicknesses are computed as described in the "Physical Properties" section, "Site 699" chapter. The sedimentation rates used to estimate the thicknesses of the missing sections are obtained from magnetostratigraphy ("Paleomagnetics" section) and biostratigraphy ("Biostratigraphy" section) only to the base of Unit II, near hiatus 3. Below that, we have used a mean sedimentation rate of $29 \mathrm{~m} / \mathrm{m}$.y. for the site.

\begin{tabular}{|c|c|c|c|c|c|c|c|c|c|}
\hline \multicolumn{10}{|c|}{$\begin{array}{l}\text { Hiatus } 1 \\
\text { (Approximate depth }=74.0-78.3 \mathrm{mbsf}, \text { Hole 701C; } \\
\text { Age of missing section }=2.8-3.1 \mathrm{~m} . \mathrm{y}_{\mathrm{*}} ; \\
\text { Approximate thickness of missing section }=15 \mathrm{~m} \text { ) }\end{array}$} \\
\hline $\begin{array}{l}\text { Relationship } \\
\text { to hiatus }\end{array}$ & $\begin{array}{l}\text { Depth } \\
\text { (mbst) }\end{array}$ & $\begin{array}{c}\text { Water } \\
\text { content } \\
(\%)\end{array}$ & $\begin{array}{l}\text { Porosity } \\
(\%)\end{array}$ & $\begin{array}{l}\text { Wet- } \\
\text { bulk } \\
\text { density } \\
\left(\mathrm{g} / \mathrm{cm}^{3}\right.\end{array}$ & $\begin{array}{l}\text { Dry. } \\
\text { bulk } \\
\text { density } \\
\left(g / \mathrm{cm}^{3}\right.\end{array}$ & $\begin{array}{c}\mathrm{CaCO}_{3} \\
\text { content } \\
(\%)\end{array}$ & $\begin{array}{l}\text { Grain } \\
\text { density } \\
\left(\mathrm{g} / \mathrm{cm}^{3}\right.\end{array}$ & $\begin{array}{c}\text { Shear } \\
\text { strength } \\
(\mathrm{kPa})\end{array}$ & $\begin{array}{c}\text { Veloc- } \\
\text { ity } \\
(\mathrm{m} / \mathrm{s})\end{array}$ \\
\hline Above & 67.3 & 61.62 & 84.42 & 1.40 & 0.54 & 0.17 & 2.63 & 59.3 & \\
\hline Above & 74.0 & 67.65 & 86.28 & 1.31 & 0.42 & 0.17 & 2.59 & 25.6 & \\
\hline Below & 78.3 & 58.92 & 82.48 & 1.43 & 0.59 & 0.50 & 3.01 & 65.2 & \\
\hline Below & 86.3 & 58.41 & 84.23 & 1.48 & 0.61 & 0.42 & 2.96 & & \\
\hline \multicolumn{10}{|c|}{$\begin{array}{c}\text { Hiatus } 2 \\
\text { (Approximate depth }=177.2-178.3 \text { mbsf, Hole } 701 \mathrm{C} ; \\
\text { Age of missing section }=6.0-8.6 \mathrm{~m} . y . ; \\
\text { Approximate thickness of missing section }=90 \mathrm{~m} \text { ) }\end{array}$} \\
\hline $\begin{array}{l}\text { Relationship } \\
\text { to hiatus }\end{array}$ & $\begin{array}{l}\text { Depth } \\
\text { (mbsi) }\end{array}$ & $\begin{array}{l}\text { Water } \\
\text { content } \\
(\%)\end{array}$ & $\begin{array}{l}\text { Porosity } \\
(\%)\end{array}$ & $\begin{array}{l}\text { Wet- } \\
\text { bulk } \\
\text { density } \\
\left(\mathrm{g} / \mathrm{cm}^{3}\right.\end{array}$ & $\begin{array}{l}\text { Dry- } \\
\text { bulk } \\
\text { density } \\
\left(\mathrm{g} / \mathrm{cm}^{3}\right.\end{array}$ & $\begin{array}{c}\mathrm{CaCO}_{3} \\
\text { content } \\
(\%)\end{array}$ & $\begin{array}{l}\text { Grain } \\
\text { density } \\
\left(\mathrm{g} / \mathrm{cm}^{3}\right.\end{array}$ & $\begin{array}{l}\text { Shear } \\
\text { strength } \\
(\mathrm{kPa})\end{array}$ & $\begin{array}{c}\text { Veloc- } \\
\text { ity } \\
(\mathrm{m} / \mathrm{s})\end{array}$ \\
\hline Above & 160.7 & 74.40 & 90.09 & 1.24 & 0.32 & 0.25 & 2.19 & 65.2 & \\
\hline Above & 168.8 & 67.89 & 84.66 & 1.28 & 0.41 & 0.17 & 2.25 & $\begin{array}{l}039.6 \\
139.6\end{array}$ & 1580.0 \\
\hline At & 178.3 & 58.25 & 79.86 & 1.40 & 0.59 & 0.17 & 2.51 & 128.0 & 1582.0 \\
\hline Below & 179.8 & 58.20 & 79.19 & 1.39 & 0.58 & & 2.67 & & \\
\hline Below & 181.3 & 59.28 & 80.90 & 1.40 & 0.57 & & 2.70 & 199.0 & 1579.0 \\
\hline \multicolumn{10}{|c|}{$\begin{array}{l}\text { Hiatus } 3 \\
\text { (Approximate depth }=246.3-253.3 \text { mbsf, Hole 701C; } \\
\text { Age of missing section }=12.6-18.5 \mathrm{~m} . \mathrm{y} ; \\
\text { Approximate thickness of missing section }=130 \mathrm{~m} \text { ) }\end{array}$} \\
\hline $\begin{array}{l}\text { Relationship } \\
\text { to hiatus }\end{array}$ & $\begin{array}{l}\text { Depth } \\
\text { (mbsf) }\end{array}$ & $\begin{array}{c}\text { Water } \\
\text { contens } \\
(\% \%)\end{array}$ & $\begin{array}{l}\text { Porosity } \\
(\%)\end{array}$ & $\begin{array}{l}\text { Wet- } \\
\text { bulk } \\
\text { density } \\
\left(\mathrm{g} / \mathrm{cm}^{3}\right.\end{array}$ & $\begin{array}{l}\text { Dry- } \\
\text { bulk } \\
\text { density } \\
\left(\mathrm{g} / \mathrm{cm}^{3}\right)\end{array}$ & $\begin{array}{c}\mathrm{CaCO}_{3} \\
\text { content } \\
\text { (\%) }\end{array}$ & $\begin{array}{l}\text { Grain } \\
\text { density } \\
\left(\mathrm{g} / \mathrm{cm}^{3}\right.\end{array}$ & $\begin{array}{c}\text { Shear } \\
\text { strength } \\
(\mathrm{kPa})\end{array}$ & $\begin{array}{l}\text { Veloc- } \\
\text { ity } \\
(\mathrm{m} / \mathrm{s})\end{array}$ \\
\hline Above & 235.3 & 53.97 & 78.00 & 1.48 & 0.68 & 3.25 & 2.94 & 123.3 & \\
\hline Above & 244.8 & 54.72 & 81.02 & 1.52 & 0.69 & 0.08 & 2.90 & & \\
\hline Above & 246.3 & 55.00 & 79.71 & 1.48 & 0.67 & & 2.88 & 130.3 & 1574.0 \\
\hline At & 247.8 & 48.75 & 73.96 & 1.55 & 0.80 & & 2.94 & & \\
\hline At & 248.7 & 51.81 & 75.32 & 1.49 & 0.72 & & 2.75 & & \\
\hline At & 248.1 & 54.33 & 78.53 & 1.48 & 0.68 & & 2.74 & & \\
\hline Below & 263.8 & 62.20 & 83.73 & 1.38 & 0.52 & 0.17 & 2.80 & & \\
\hline Below & 265.3 & 62.14 & 84.79 & 1.40 & 0.53 & & 2.66 & & \\
\hline \multicolumn{10}{|c|}{$\begin{array}{l}\text { Hiatus } 4 \\
\text { (Approximate depth }=253.3-262.8 \text { mbsf, Hole 701C; } \\
\text { Age of missing section }=19-21.5 \text { m.y.; } \\
\text { Approximate thickness of missing section }=40 \mathrm{~m} \text { ) }\end{array}$} \\
\hline
\end{tabular}


Hiarus 5

Approximate depth $=386.3-395.8 \mathrm{mbsf}$, Hole $701 \mathrm{C}$

25 or $29-34$ m.y:

Approximate thickness of missing section $=170-200 \mathrm{~m}$ )

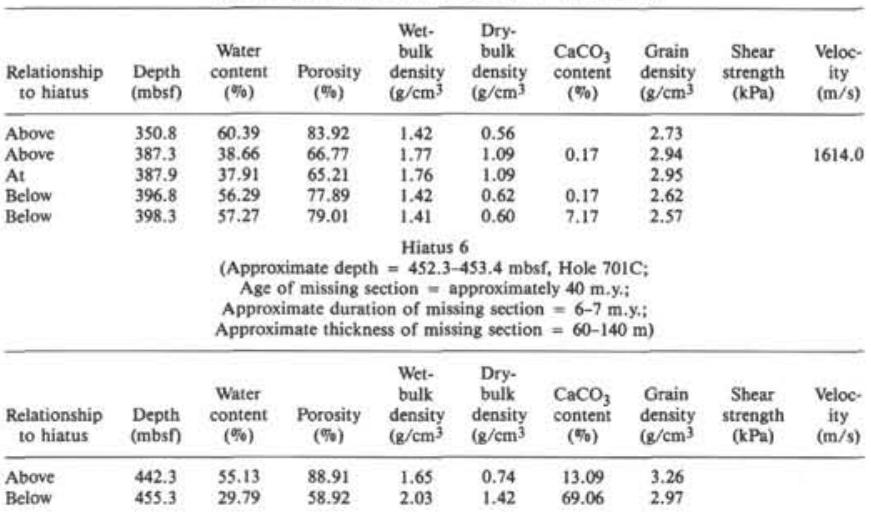

We will briefly discuss each hiatus in turn. Hiatus 1 occurs within Subunit IA, well away from lithostratigraphic boundaries. Despite the thin segment of missing sediment, hiatus 1 is clearly apparent in the physical properties, except perhaps for the porosity. The decrease in water content and associated increase in the bulk densities and shear strength are suggestive of a sediment-removal event. Hiatus 2 occurs just below the lithostratigraphic boundary between Subunits IC and ID. The changes in the physical properties from Subunits IB to ID, from 160.7 to $168.8 \mathrm{mbsf}$, are not as sharp as those resulting from the hiatus, from 168.8 to 178.3 mbsf. The hiatus is not masked by the lithostratigraphic boundary. The decrease in water content and porosity and the increase in bulk densities again indicate sediment removal.

Hiatus 3 lies just below a lithostratigraphic boundary, between Units I and II. As for hiatuses 1 and 2, a small but distinct decrease in water content and porosity and associated increases in the bulk densities lead us to suggest a sediment-removal event. The changes in the physical properties allow us to estimate the depth interval within which hiatus 3 occurs as 246.3-247.8 mbsf, instead of 246.3-253.3 mbsf. Hiatus 4 also occurs below the lithostratigraphic boundary between Units 1 and II, directly below hiatus 3 . There are significant changes in the physical properties from 248.1 to $263.8 \mathrm{mbsf}$, but in this case the water content and porosity increase rather than decrease. We would suggest, therefore, that hiatus 4 arose from nondeposition of sediment rather than removal.

Hiatuses 5 and 6 bracket the lithostratigraphic boundaries between Subunits IIA and IIB and Units II and III, respectively. The sampling across these boundaries is too coarse to be able to determine clearly whether the hiatuses are apparent in the physical-property variations or not, though the sharp decrease in water content and porosity and the associated increase in bulk densities just above the base of Unit II may represent hiatus 5. If that is the case, then hiatus 5 would be of the sediment-removal type.

In conclusion, we see clear evidence in the physical-property variations to support the presence of hiatuses 1 through 4 , and possibly 5 , in spite of the close association of the hiatuses with lithostratigraphic boundaries. All but one of the hiatuses, number 4 , are of the sediment-removal type. Hiatus 4 may be representative of a period of sediment nondeposition.

\section{SEISMIC STRATIGRAPHY}

The location of Site 701 was chosen on the basis of an eastwest, Polar Duke (Cruise 0186) single-channel seismic-reflection line that displays the contrast in acoustic character within the sediments very well (Figs. 1 and 3). JOIDES Resolution arrived at the site in high following seas (sea state 8). The original site location was difficult to identify in the relatively noisy underway seismic record, and the vessel proceeded along the original seismic line about $10 \mathrm{nmi}$ farther east before the beacon was dropped (Fig. 1). The sedimentary section here was more laterally uniform. Upon leaving the site, the high sea state seriously downgraded the underway seismic data recorded by the drilling vessel.

At Site 701 , the predominantly siliceous section shows a remarkable downhole uniformity in physical properties. Seismic $P$-wave velocity shows a linear increase of only $10 \mathrm{~m} / \mathrm{s}$ from a value of $1560 \mathrm{~m} / \mathrm{s}$ over a depth range of $400 \mathrm{~m}$, with fluctuations in the $0-100 \mathrm{~m} / \mathrm{s}$ range superimposed. The observed depth to basement implies an average velocity of $1600 \mathrm{~m} / \mathrm{s}$ for the entire section. The porosity is nearly constant around $85 \%$, but is reduced to $60 \%$ in the basal chalk. Wet-bulk density and grain density show relatively large variations, particularly in the upper unit.

A faint bottom reflection in the $3.5-\mathrm{kHz}$ record and an emergent return of the air gun signal indicate that the sub-bottom sediments are very soft (Figs. 28 and 29). Discrete or dispersed ash layers seem to correlate with some of the reflections in the $3.5-\mathrm{kHz}$ data, with the first 10-cm-thick layer at $5 \mathrm{mbsf}$ (Hole 701A) particularly strong (Fig. 29). The ash represents a $50 \%$ increase in wet-bulk density and a reduction of $30 \%-40 \%$ in porosity and water content relative to the host sediment (Table 10; "Physical Properties" section, this chapter). The high-resolution data show the same reflection strength for the ash layers in topographic lows as over a sloping bottom, which indicates that redistribution by bottom currents of an originally uniform deposit has been only minor. Reflections at 15-17 mbsf and 32$34 \mathrm{mbsf}$ correlate with strong variations of mud and dispersed ash in the diatom ooze.

Acoustic stratification within the upper $100 \mathrm{~m}$ of sediments is probably generated by fluctuations in wet-bulk density on the order of $10 \%$ over depth intervals of about $20 \mathrm{~m}$ (Fig. 28). This may in turn be related to the frequency of ash layers and mud intervals in this part of the section. A $15 \%$ drop in porosity at 115 mbsf does not appear to give rise to a reflection. However, the change in lithology at $145.5 \mathrm{mbsf}$ from diatom ooze to the underlying monospecific diatom ooze ( $30.5 \mathrm{~m}$ thick), with a more than 2-m-thick interbedded sand/gravel unit, has a distinct expression in the physical properties and appears to be associated with a laterally continuous band of reflections. The major stratigraphic hiatuses at the top of the siliceous clay/mud unit covering time gaps of the order of 8 and $>2 \mathrm{Ma}$, respectively, can be discerned in the seismic record as truncations about $1 \mathrm{~km}$ east of the site. No significant changes are observed at this level in the physical properties either.

The lower band of reflections (370-415 ms) in the seismic record shows no apparent correlation variations in physical properties or lithology within the corresponding interval (280-320 mbsf). No hiatuses are present in this depth interval. Compilation of the smear slide data shows high clay content throughout the upper Oligocene siliceous clay/mud unit (Fig. 28). Unfortunately, changes in relative proportions of clay or mud are not brought to light by the available data, whereas variation in these components has significant influence on the reflective properties of the sediments (Bayer and Ott, 1983). From the shipboard analysis, the only change observed for the interval 280-320 mbsf is a minimum in the abundance of diatoms (see Fig. 17; "Biostratigraphy" section). Determination of whether this is associated with any changes in lithology or not must await further shore-based work. We note that the reflection event seems to be represented by more cycles and therefore, a thicker clay(?) interval within topographic lows than over elevated areas. For the moment, we assume as a working hypothesis that the higher reflectivity is related to a higher content of clay in the siliceous clay/mud unit. 


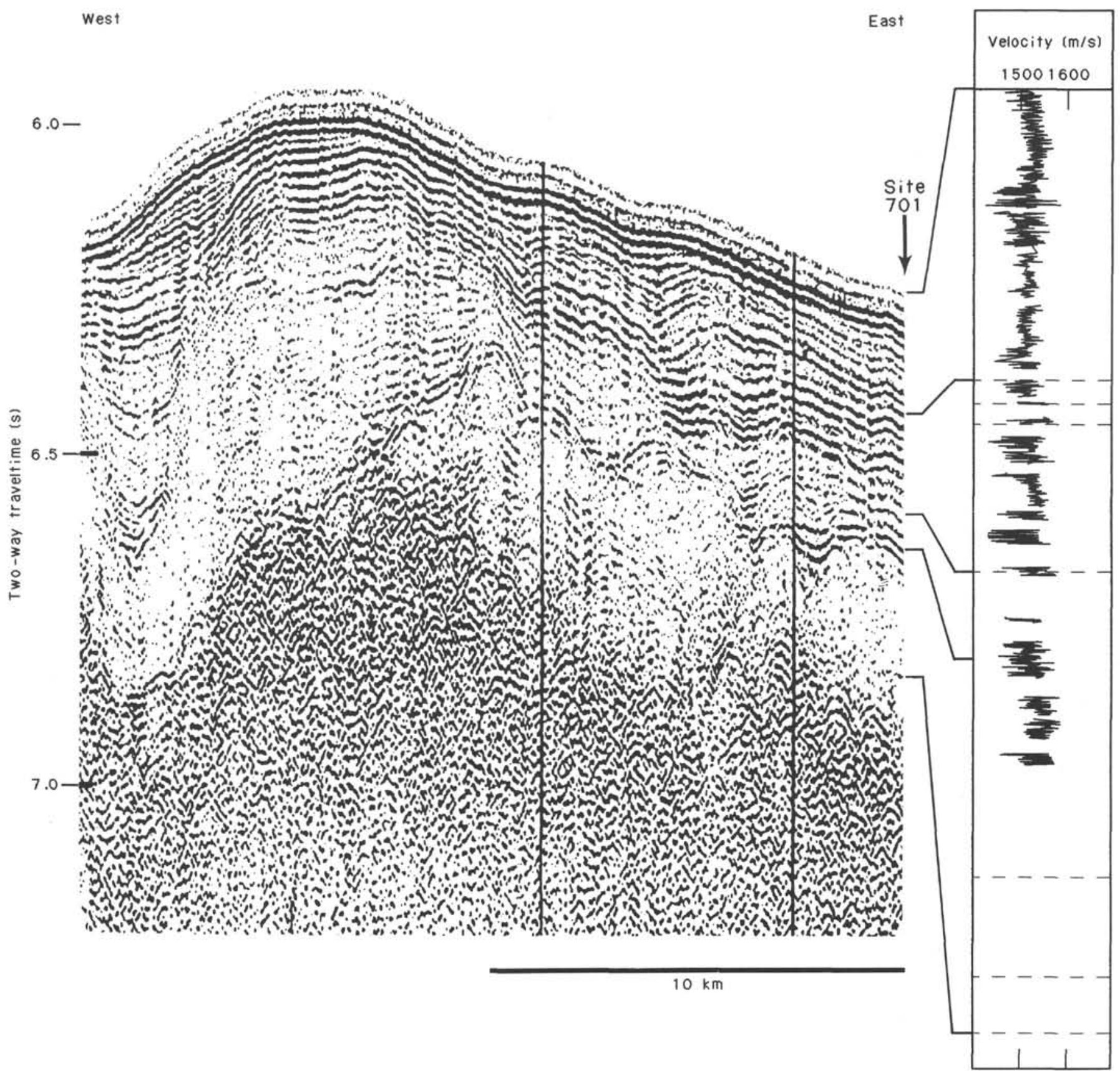

Figure 28. Summary of physical properties (from "Physical Properties" section), lithology (from "Lithostratigraphy" section), and age (from "Biostratigraphy" section) of Site 701 correlated with single-channel seismic-reflection data obtained by Polar Duke (Cruise 0186) over the general site location (1313 GMT, 27 August 1986).

The transition from the nannofossil-bearing siliceous clay/ mud to the middle Eocene basal indurated chalk represents a $60 \%$ increase in wet-bulk density. Although no velocity measurements are available, the lack of an associated reflection is surprising. Likewise, the sediment/basement interface is not well expressed acoustically. Perhaps these attributes are a result of low signal level in the late part of the record.

The seismic data show evidence of an apparent change in the depositional regime in which deposition of the upper stratified unit was initiated by an increase in the supply of terrigenous material, as previously inferred. Along the eastern foot of the Islas Orcadas Rise, deposition was preceded by an erosional event, which also implies an increase in the intensity of northward bottom-water flow (Fig. 28). Large and irregular, but smooth, lateral changes in the thickness of the upper stratified unit are characteristic of sediments laid down under the influence of bottom currents. The crests of individual sediment lenses within the irregular basement topography have remained stationary or have migrated only slightly with time. The temporal and spatial pattern of bottom-water flow has therefore remained rather stable since the onset of any significant bottom circulation.

The inferred increase in terrigenous supply at Site 701 occurred in the late Oligocene, and slightly earlier at Site 699, in the early late Oligocene. A major erosional event at the early/ late Oligocene boundary has been observed on many continental margins and has been related to a fall in the global sea level (Vail et al., 1977). Although the magnitude of sea-level change (Schlanger and Premoli Silva, 1986) and its physical cause 


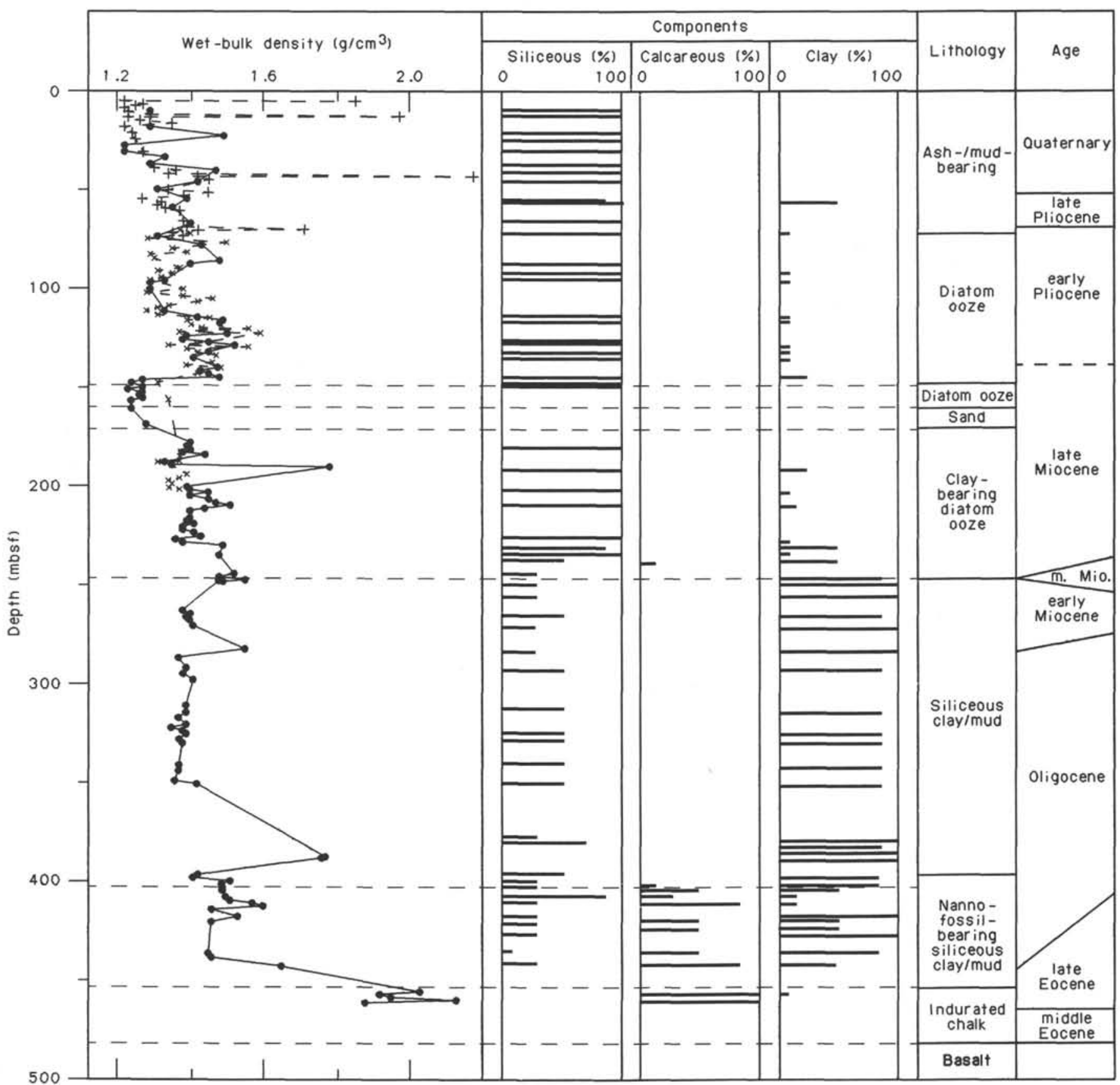

Figure 28 (continued).

(Miller et al., 1985) are disputed, its effect was to form an unconformity and numerous canyons at the continental margins, thereby providing transfer of terrigenous material to the deep sea. The increase in clay input seen at Sites 699 and 701, where Oligocene sediments have been recovered, may therefore reflect an enhanced supply of terrigenous material to the Weddell Basin from the surrounding land masses during the Oligocene sealevel low stand. The clay was then transported northward within the benthic boundary layer of an emerging deep-water communication with the South Atlantic.

\section{SUMMARY AND CONCLUSIONS}

\section{Summary}

Site 701 is on the western flank of the Mid-Atlantic Ridge $\left(51^{\circ} 59.08^{\prime} \mathrm{S}, 23^{\circ} 12.73^{\prime} \mathrm{W}\right.$; water depth of $\left.4634 \mathrm{~m}\right)$, about 160 $\mathrm{km}$ east of the Islas Orcadas Rise on oceanic crust of middle Eocene age (Chron C22). The major objective of this site was to obtain a continuous sediment record of the development of an oceanic gateway for deep circulation between the South Atlantic and the high-latitude region to the south. Site 701 is situated within the gateway and, in conjunction with Sites 699 and 700, will provide the basis for interpretation of the history of deepwater circulation through the gateway as a result of its increasing width and the subsidence of the surrounding seafloor. A review of other Site 701 objectives is given in "Background and Objectives" section, this chapter.

The sediments above the oceanic crust east of the Islas Orcadas Rise are characterized by an upper, acoustically well-stratified unit with conformable, undulating bed forms comprising two-thirds or more of the total section (Fig. 3). The top of the underlying transparent unit is conformable to a large extent 


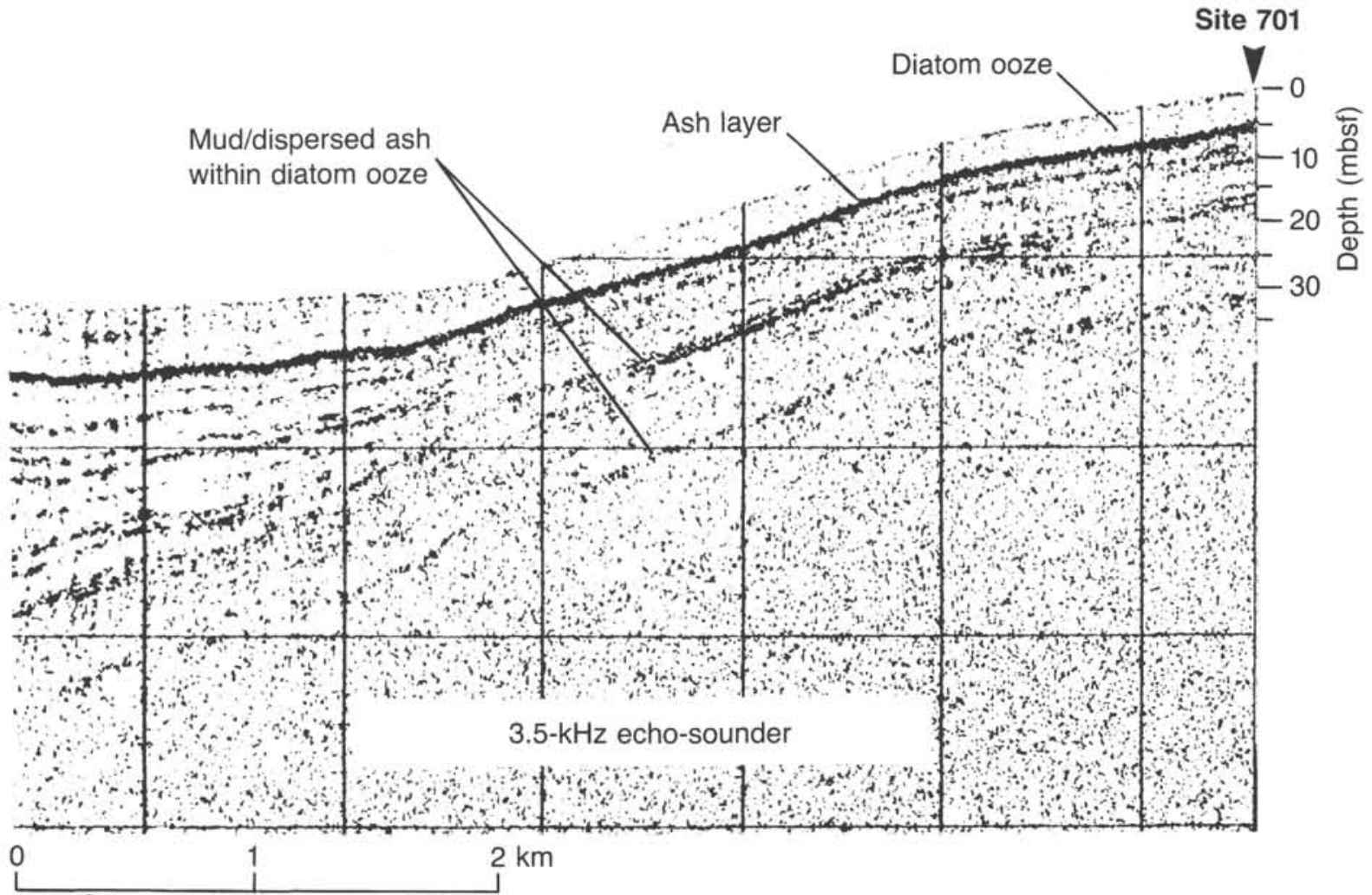

Figure 29. High-resolution $(3.5-\mathrm{kHz})$ seismic-reflection profile over Site 701 acquired by JOIDES Resolution.

with basement topography, with some irregular apparent incisions that may be erosional surfaces. The sediment distribution and bed-form geometry clearly indicate that the upper unit represents a major change to a depositional environment characterized by stronger bottom currents.

Three holes were drilled at Site 701: Hole 701A, with 8 cores obtained with the APC to a depth of $74.8 \mathrm{mbsf}$ for a recovery of $69.66 \mathrm{~m}(93.1 \%)$; Hole $701 \mathrm{~B}$, with 10 cores obtained with the APC and 4 with the XCB systems between 70 and 203 mbsf for a recovery of $96.4 \mathrm{~m}(72.5 \%)$; and Hole $701 \mathrm{C}$, with 24 cores obtained with the APC and 27 with the XCB systems, penetrating to $481.3 \mathrm{mbsf}$ for a recovery of $331.1 \mathrm{~m}(68.8 \%)$. A flared XCB bit prevented retrieval of the core barrel after penetration of a hard layer at $477 \mathrm{mbsf}$. Subsequent preparations to log through the pipe were abandoned after the drill string temporarily became stuck above the jars.

The stratigraphic section at Hole $701 \mathrm{C}$ consists of $400 \mathrm{~m}$ of mostly biosiliceous and diatom ooze, siliceous clay/mud, and clay-bearing diatom ooze overlying a 72 -m-thick sequence that shows increasing carbonate content with depth. Stratigraphic sequences of the three holes of Site 701 are divided into four lithostratigraphic units based upon compositional changes in lithology. Further subdivision into six subunits is based on both lithologic and paleontologic characteristics (Table 2 and Figs. 4 and 30 ).

Unit I (0-243.8 mbsf) is predominantly a diatom ooze with varying admixtures of clay, mud, and numerous zones of discrete and dispersed volcanic ash. Four distinctive subunits were defined in this upper Miocene to Quaternary sequence. Subunit IA (0-74.8 mbsf, Hole 701A; 70.0-147.5 mbsf; Hole 701B; 0$145.5 \mathrm{mbsf}$, Hole $701 \mathrm{C}$ ) is an upper Miocene to Quaternary ashand/or mud-bearing diatom ooze, with discrete ash horizons and dispersed ash throughout. A distinctive diatom ooze of late
Miocene age forms Subunit IB (147.5-174.76 mbsf, Hole 701B; 145.5-160.9 mbsf, Hole 701C). This subunit is a nearly monospecific ooze of the diatom Bruniopsis mirabilis, with varvelike laminations, high organic carbon content, pyrite, and no apparent bioturbation. Subunit IC (174.76-183.71 mbsf, Hole 701B; 160.9-167.96 mbsf, Hole 701C) is a sand and gravel unit containing quartz, biotite, metapelites, iron-coated schists, pumice, and mud clasts. The combined stratigraphic succession of Holes $701 \mathrm{~B}$ and $701 \mathrm{C}$ indicates that this subunit was deposited in the late Miocene during deposition of Subunit IB, as the unit is overlain and underlain by Bruniopsis ooze in Hole 701C. Subunit ID (183.71-203.0 mbsf, to the base of Hole 701B; 167.96243.8 mbsf, Hole 701C) is a middle to upper Miocene (only middle Miocene in Hole 701C) thick sequence of clay- or mudbearing diatom ooze, with discrete and disseminated horizons of volcanic ash. In Hole $701 \mathrm{C}$ the top $2.24 \mathrm{~m}$ of this subunit consists of Bruniopsis ooze, which underlies the sand and gravel of Subunit IC.

The transition from Unit I to Unit II is marked by a change from clay-bearing diatom ooze to diatom mud, with a decrease in the abundance of volcanic ash. Subunit IIA (243.8-395.15 mbsf) consists of diatom-bearing mud/clay, siliceous-bearing mud/clay, and siliceous mud/clay. Altered ash horizons are a conspicuous component of this early-middle Miocene subunit. Alternations of three major lithologies (i.e., nannofossil ooze, siliceous ooze, and clay), occur within the upper Eocene-lower Oligocene of Subunit IIB (395.15-452.8 mbsf).

Unit III (452.8-481.3 mbsf) is a middle Eocene indurated nannofossil chalk with an average carbonate content of $80 \%$. This unit exhibits the highest carbonate content of the stratigraphic section and directly overlies basement or a sill. Unit IV (481.3-481.47 mbsf) consists of a single piece of variably altered amygdaloidal olivine basalt that represents oceanic crustal base- 


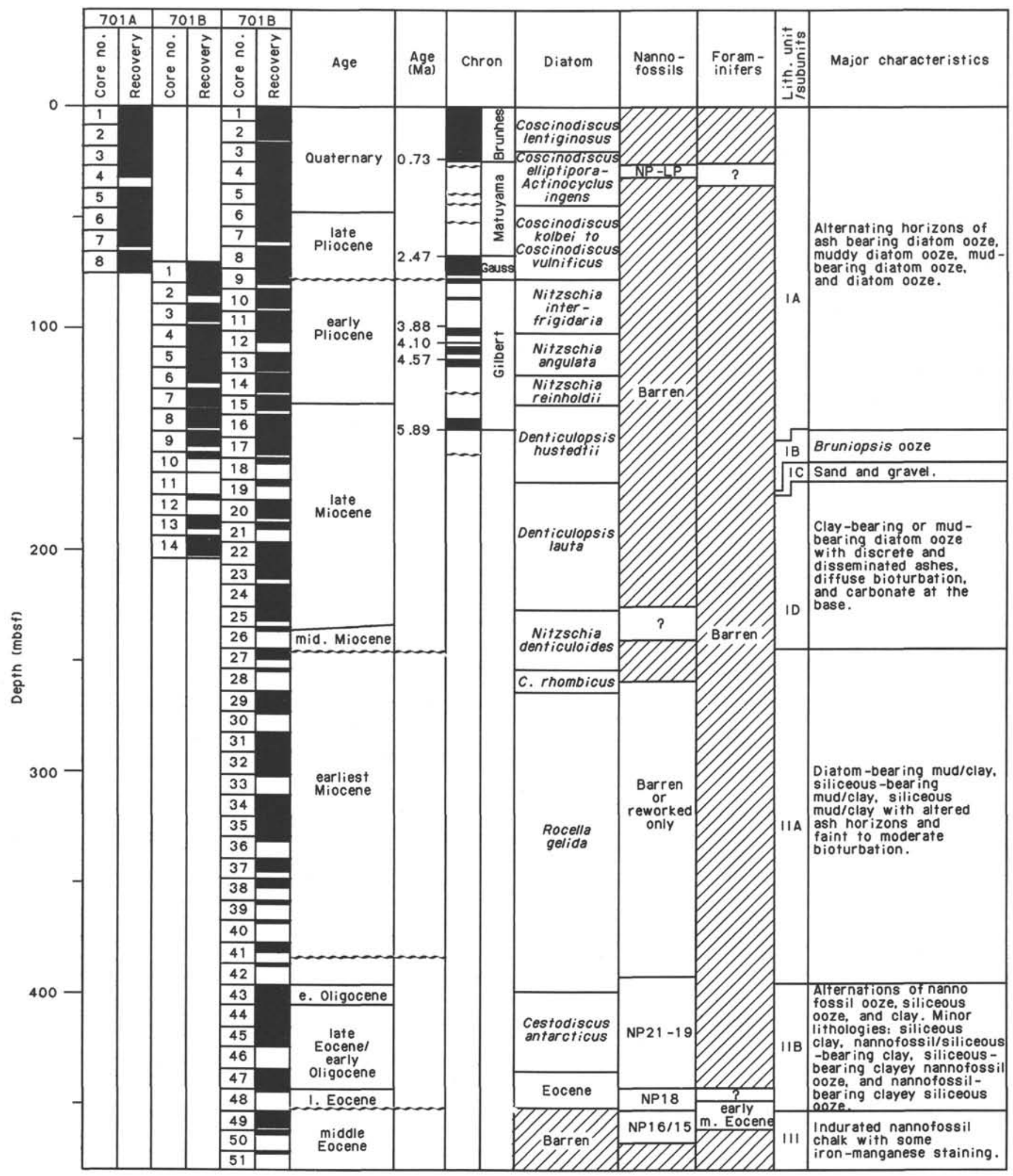

Figure 30. Summary of selected data from Site 701, including depth, sediment recovery, age (from Hole 701C only), paleomagnetic polarity zones correlated to GPTS, selected micropaleontologic zones or ages, lithologic units and subunits with a description of their major characteristics, variations in smear slide constituents, percent carbonate, and porosity. 


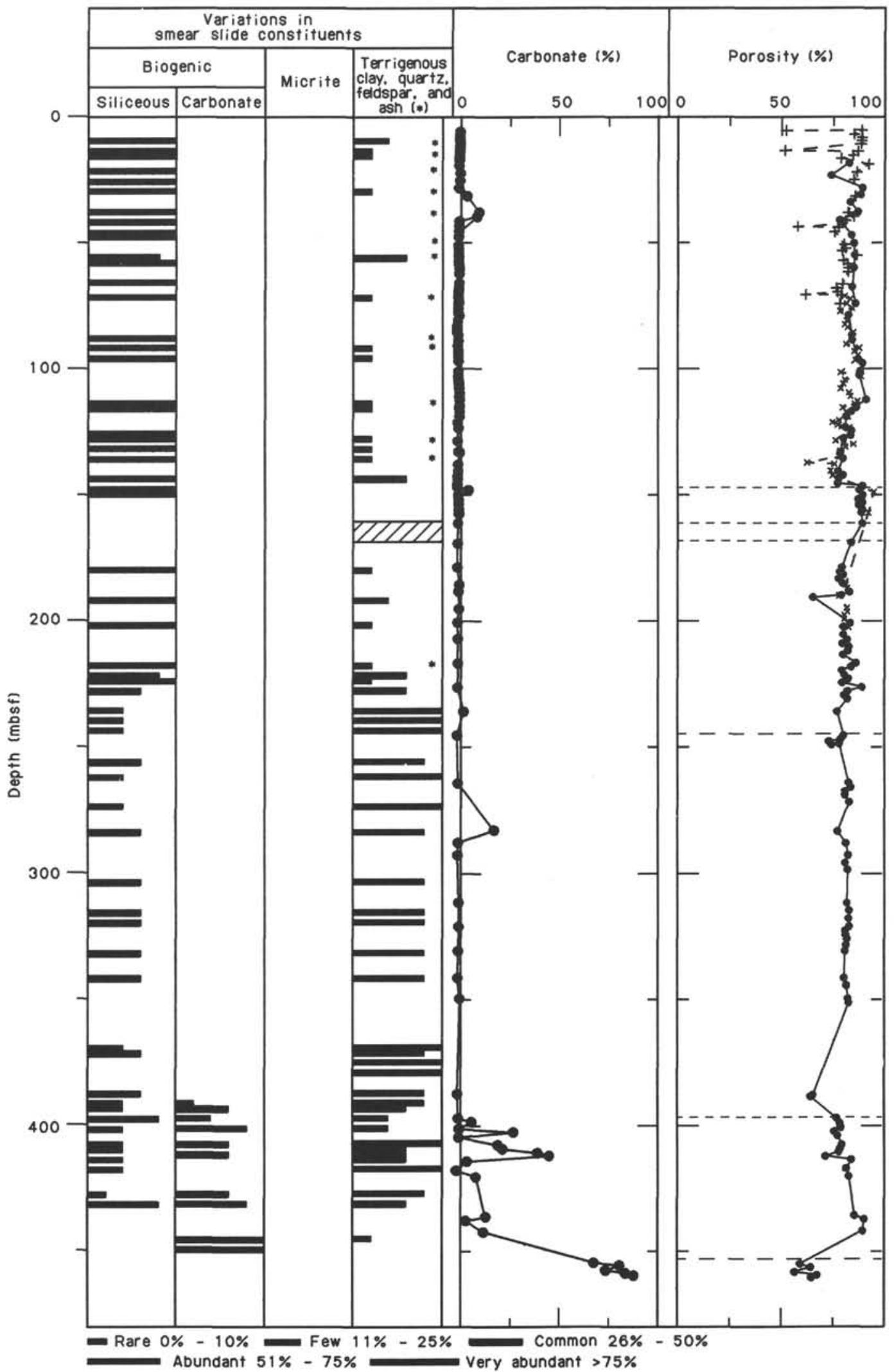

Figure 30 (continued). 
ment or possibly an interbedded sill.

The sedimentary record of Site 701, the only Leg 114 site under the influence of AABW, differs significantly from our previous sites, which are under the influence of CPDW. The Neogene sequence is thicker and the Paleogene is more attenuated than at previous sites. Biogenic sedimentation was dominantly calcareous during the middle Eocene and biosiliceous in the late Eocene-Quaternary. Siliceous microfossils provide a detailed biostratigraphy of the Neogene that is complemented by a paleomagnetic record of the Brunhes Chron to Chron C3AN. Biostratigraphic resolution of the middle Eocene to early Oligocene is provided by calcareous and siliceous microfossil groups.

Two hiatuses occur within the Paleocene section of Hole 701C. One hiatus includes the upper middle Eocene and possibly the lowermost upper Eocene, with maximum to minimum estimates for the duration of $7.0(\sim 46.0-39.0 \mathrm{Ma})$ to $2.4 \mathrm{~m} . \mathrm{y}$. ( 42.3-39.9 Ma). The second Paleogene hiatus encompasses the upper lower Oligocene and upper Oligocene with a duration of $11.6(35.0-23.4 \mathrm{Ma})$ to $8.6 \mathrm{~m} . \mathrm{y}$. (32.0-23.4 Ma). Given the uncertainty of the age range of these hiatuses, sedimentation rates for the intervening upper Eocene-lower Oligocene were within a range of 8 to $15 \mathrm{~m} / \mathrm{m}$.y.

A minimum of three hiatuses were detected within the Neogene sequence of Holes 701A through 701C. The oldest of these includes the upper lower Miocene and most or all of the upper Miocene, with a maximum duration of 7.6 m.y. ( 19.0-11.4 $\mathrm{Ma})$ and minimum duration of $4.6 \mathrm{~m} . \mathrm{y}$. ( 19.0-14.4 Ma). A second Neogene hiatus occurs within the upper Miocene, representing an approximate 2.3-m.y. period ( $~ 8.7-6.4 \mathrm{Ma})$. A final, brief hiatus occurs within the upper Pliocene between $\sim 3.0$ and $2.5 \mathrm{Ma}$.

Neogene sedimentation rates were highly variable. Although biostratigraphic control is poor for the lower Miocene (Subunit IIB) there is little doubt that the sedimentation rate was very high, as great as $68 \mathrm{~m} / \mathrm{m}$.y. Following the resumption of deposition after formation of the lower Neogene hiatus, sedimentation rates were much lower $(9-14 \mathrm{~m} / \mathrm{m}$.y.) during the middle to early late Miocene. The mean sedimentation rate for the late Miocene through early Pliocene was $\sim 19 \mathrm{~m} / \mathrm{m}$.y. After the formation of the Gauss Chron hiatus $(\sim 3.0-2.5 \mathrm{Ma})$, sedimentation rates averaged $\sim 28 \mathrm{~m} / \mathrm{m}$.y. for the remainder of the late Pliocene-Quaternary.

Calcareous microfossils are relatively minor constituents of the microfossil assemblage of Site 701, except in the middle Eocene. Calcareous nannofossils and planktonic foraminifers are almost totally absent from the upper Miocene-Quaternary. The only significant occurrence of planktonic foraminifers is in the middle Eocene, where they are moderately well preserved and abundant. Benthic foraminifers are barren or sparse, except in the middle Eocene where rich, well-preserved fauna were found.

Siliceous microfossil groups are abundant, diverse, and moderately well preserved in the middle Miocene-Quaternary sediments and are abundant but less diverse and exhibit fair to moderate preservation in the lower Miocene. Upper Eocene to lowermost Oligocene sediments contain sparse and poorly preserved siliceous microfossils. Middle Eocene sediments are almost devoid of these microfossil groups.

\section{Conclusions}

\section{Seismic and Tectonic Interpretation}

The sediments deposited within the gateway have a well-defined acoustic stratification, which extends down to $320 \mathrm{mbsf}$ at Site 701 (assuming a velocity of $1600 \mathrm{~m} / \mathrm{s}$ ). The underlying lower Miocene section appears to be acoustically transparent (Fig. 28). Shipboard physical-property measurements indicate that although the $P$-wave velocity is nearly constant with depth, the variations in wet-bulk density related to changes in the proportions of ash, mud, or clay within the diatom ooze may explain impedance contrasts in the upper $250 \mathrm{~m}$ of sediments (middle Miocene or younger). However, the change in reflectivity at $320 \mathrm{mbsf}$ in the siliceous clay/mud unit does not appear to correspond to a significant change in either physical properties or lithology. We assume that it represents alternating intervals of higher clay content that reflect an increase in the supply of terrigenous material from the continental margins around the Weddell Basin. Along the eastern foot of Islas Orcadas Rise, deposition was preceded by an erosional event that is inferred to have been caused by an increase in the intensity of the northward-flowing AABW. The distribution and stationary nature of the undulating bed forms in the upper reflective sequence show that the temporal and spatial pattern of bottom-water flow has remained stable since the onset of any significant benthic circulation.

\section{Paleoenvironmental History}

\section{Middle Eocene (between 52 and 46-42 Ma; 471.94 to 453.1-452.8 mbsf)}

Site 701 is situated on oceanic crust formed during the late early Eocene (anomaly 22, $\sim 52 \mathrm{Ma}$ ). As the oceanic crust at Site 701 was forming at the spreading center between the Islas Orcadas Rise and Meteor Rise ( $\sim 52 \mathrm{Ma})$, the gateway was relatively shallow (2500-3000 m below sea level-mbsl) and narrow $(150 \mathrm{~km})$.

Although middle Eocene benthic circulation was weaker than today, water-mass density contrasts to the north and south of the gateway were probably sufficient to initiate strong benthic circulation through the gateway. The presence of redeposited microfossils, older than or of the same age as the gateway, is evidence for the erosion and redeposition of sediment during the early development of the gateway.

Relatively warm surface waters and a deep CCD resulted in the accumulation of abundant and moderately well-preserved planktonic foraminifers with lower latitude affinities. Assemblages are similar to those encountered in the lower middle Eocene of the previous Sites 698, 699, and 700, indicating widespread warm surface waters throughout the subantarctic South Atlantic.

\section{Middle to Late Eocene Hiatus (duration 2.4-7.0 m.y.; 453.1-452.8 mbsf)}

An upper middle Eocene hiatus is present between Cores 114-701C-48X and 114-701C-49X, separating nannofossil Zone NP15/16 from NP18. Given the uncertainty of the stratigraphic resolution, the hiatus is indicative of a missing interval of 2 to 7 m.y. Previous results from Sites 699 and 700 indicate that this hiatus was formed during a period of major cooling from the maximum Cenozoic warmth conditions recorded during the early Eocene. Cooling of surface waters had begun by $\sim 50-51 \mathrm{Ma}$ and had greatly diminished the abundance of low-latitude planktonic species by $\sim 45$ to $46 \mathrm{Ma}$. By the time deposition resumed at Site 701 (NP18, $\sim 40-38 \mathrm{Ma}$ ), planktonic assemblages at Sites 699 through 701 exhibited a definite high-latitude, cool surface-water affinity.

Middle to late Eocene erosion or nondeposition at Site 701 is indicative of an increase in thermohaline-driven deep abyssal circulation. In spite of an increase in the width of the Islas Orcadas Rise-Meteor Rise gateway, late middle to early late Eocene circulation through the passageway increased. The apparent increase in the vigor of benthic circulation at this time may be related to the formation of pre-AABW as a consequence of late Eocene growth of the antarctic ice sheet and cooling of surface waters around the antarctic margin. 
Late Eocene to Early Oligocene ( 39-35 Ma; 452.8 to 395.8-386.3 mbsf)

Deposition was renewed at Site 701 by $\sim 40-38 \mathrm{Ma}$; however, sedimentation was slow $(8-15 \mathrm{~m} / \mathrm{m} . \mathrm{y}$.) and probably discontinuous, resulting in the deposition of only $\sim 60 \mathrm{~m}$ of upper Eocene to lower Oligocene section. Subsidence of the site to $\sim 4000 \mathrm{~m}$ by the early Oligocene led to the last consistent occurrence of carbonate at this time. At other Leg 114 sites this period is marked by a much lower calcareous microfossil diversity and the dominance of high-latitude taxa. As at Site 699, some warm-water and cosmopolitan diatom species persisted into the early Oligocene; however, these also disappeared by the late Oligocene. The increased influence of much cooler surface waters at this time is not as conspicuous at Site 701 because of the effects of dissolution on the assemblages. The much lower sedimentation rates at this site relative to Sites 699 and 700 are no doubt related to higher current velocities within regions influenced by preAABW, particularly within the western margin of the Islas Orcadas Rise-Meteor Rise gateway. A significant increase in the deposition of clay between the middle and late Eocene may have been caused by increased terrigenous supply to the circum-antarctic region by glacial denudation of the Antarctic continent and increased nepheloid transport by pre-AABW.

\section{Early Oligocene-Early Miocene Hiatus ( 8.6-11.6 m.y. duration; $\sim 35$ to $32-23.4 \mathrm{Ma}$; $395.15 \mathrm{mbsf}$ )}

An 8.6- to 11.6-m.y. hiatus separates the lower and upper Oligocene at Site 701. Until the age of this hiatus can be established with greater reliablity, its relationship to major Oligocene oxygen isotopic fluctuations is unclear. At the present time it would appear to encompass more than the $\delta^{18} \mathrm{O}$ enrichment noted at $\sim 31-28 \mathrm{Ma}$ (Miller et al., 1985) and the major eustatic fall in sea level at $\sim 30 \mathrm{Ma}$ (Vail et al., 1977). These events are interpreted to be the consequence of an antarctic ice volume increase that may have cooled and invigorated benthic circulation. The source of abyssal waters responsible for nondeposition or erosion at Site 701 at this time is inferred to have been the Weddell Sea because a deep-water gap had not yet formed in the Drake Passage.

\section{Earliest Miocene ( 23.4-19.0 Ma; 395.15-246.30 mbsf)}

Biostratigraphic control for the latest Oligocene-earliest Miocene is very poorly restrained, particularly in Southern Ocean regions. Furthermore, the presence of bracketing hiatuses above and below this sequence (Subunit IIA) creates further difficulties in accurately determining its age (Table 4 and Fig. 13). Nevertheless, the entire $151 \mathrm{~m}$ of Subunit IIA appears to have been deposited during a very brief span of time $(\sim 4.4$ m.y.) in the early Miocene.

The early Miocene of lithostratigraphic Subunit IIA is composed of diatom-bearing mud/clay, siliceous-bearing mud/clay, and siliceous mud/clay. As the lithologies indicate, fine-grained terrigenous clays are the predominant sediment type, with only minor fluctuation in the abundance of biogenic silica. The exceptional early Miocene sedimentation rate of $\sim 68 \mathrm{~m} / \mathrm{m}$.y. appears to be partially attributed to major increase in the accumulation rate of terrigenous sediment. Although upper Eocenelower Oligocene sediments from this site also have a large terrigenous component, they were deposited at a lower rate.

The sedimentation rate and mud/clay content of the earliest Miocene of Hole 701C are significantly higher than in the Oligocene to earliest Miocene of Hole 699A in the East Georgia Basin. The thickness of age-equivalent sediment at Hole 699A is less than $30 \mathrm{~m}$. Within this interval in Hole 699A, upper Subunit IIA, carbonate deposition ended (except for sporadic occurrences), thereby marking the northward advance of the polar front and the accompanying biosiliceous productivity zone. At the deeper and more southerly Site 701, a thicker accumulation of age-equivalent sediment was deposited as a result of an increased influx of fine-grained terrigenous detritus carried by AABW or its precursor.

The early Miocene appears, therefore, to have been a time of major changes in surface-water productivity patterns, terrigenous sediment supply, and shallow to deep ocean circulation in the northern antarctic to subantarctic southwest Atlantic. These changes appear to have been, for the most part, directly or indirectly related to the latest Oligocene-early Miocene opening of the Drake Passage. By the earliest Miocene, a vigorous, true ACC was established, leading to the abrupt end of the dominance of calcareous sedimentation (Site 699) as a result of the permanent northward migration of the mean position of the polar front and the biosiliceous productivity zone. Diatom assemblages of early Miocene age lack the lower latitude species present in the early Oligocene, in keeping with the progressive cooling of surface waters brought on by the ACC.

During and after the early Miocene, some brief periods of climatic amelioration brought on temporary southward retreats of the polar front, allowing intervals of minor calcareous sedimentation (Fig. 11). One such lower Miocene interval contains only calcareous nannofossils, indicating deposition below the foraminiferal lysocline and a CCD below $4000 \mathrm{mbsl}$.

The large volume of terrigenous sediment carried to and deposited by AABW within the Islas Orcadas Rise-Meteor Rise gateway is probably multisourced. One probable source is the Andes-Antarctic Cordillera, which shed sediment into the widening Drake Passage in this tectonically active region to be carried eastward by AABW. Other major sources were likely, including portions of the Antarctic margin, which heretofore may not have been glaciated. The initial advance of ice onto such margins would be expected to produce a large influx of terrigenous sediment by mass-wasting processes and turbidite influx into the surrounding basins. Accompanying the deposition of this transported terrigenous sediment were redeposited early Eocene to Oligocene microfossils.

\section{Early Miocene to Middle Miocene Hiatus (4.6-7.6 m.y. duration; $\sim 19$ to $14.4-11.4 \mathrm{Ma} ; 253.3-246.3 \mathrm{mbsf}$ )}

An abrupt change in the physical properties and siliceous microfossil assemblages between 253.3 and 246.3 mbsf marks the hiatus between the lower Miocene and upper middle Miocene. Physical-properties changes across this hiatus suggest a removal of $\sim 130 \mathrm{~m}$ of sediment. This hiatus is very similar in duration to that at Site 699 (3708 mbsl), whereas it is shorter in duration than the Paleogene to middle upper Neogene hiatuses at shallower sites. We believe that these hiatuses are related to deepcutting erosional episodes caused by the onset of more vigorous circulation as a deep-reaching ACC was established (see "Summary and Conclusions" section, "Site 699" chapter).

It is apparent at this site that the early to middle Miocene period of nondeposition and erosion by $\mathrm{AABW}$ (or its precursor) postdates deep-water gap formation in the Drake Passage $(\sim 23.5$ m.y. \pm 2.5 m.y.; Barker and Burrell, 1977, 1982). Subsequently, sedimentation resumed, allowing deposition of over $100 \mathrm{~m}$ of Miocene sediments, which were later removed by the lower Miocene-middle Miocene hiatus ("Physical Properties" section). The resumption of deposition after the Drake Passage opening may have been caused by tectonic blockage of AABW (or its precursor) east of the Drake Passage (see "Background and Objectives" section, "Site 699" chapter). It is possible that the lower to middle Miocene hiatus at Sites 699 and 701 and the Paleogene to upper Neogene hiatus at Sites 698 and 700 were formed much later than the opening of the Drake Passage. The erosional event(s) that formed these hiatuses removed signifi- 
cant thicknesses of Miocene sediments prior to the late middle Miocene. This suggests that the major erosional episode(s) may have been late early to late middle Miocene in age.

\section{Middle to Early Late Miocene ( 14.4-11.4 to 8.7 Ma; 253.3-246.3 to $\sim 178 \mathrm{mbsf}$ )}

The late middle to late Miocene sediments of Unit I still have a major terrigenous component; however, it is subordinate to the biosiliceous major constituent. The increase in the biosiliceous component is at least in part related to higher biosiliceous productivity caused by early Miocene migration of the polar front and biosiliceous province to near its present position. Some reduction in the supply of terrigenous sediment may have occurred during the Neogene after the more easily erodible sediment on the Antarctic continent was removed by the expanding ice sheets. An increase in volcaniclastic sediments also occurred during the early Neogene, increasing even more during the late Neogene (see next section).

Some warming of surface waters occurred during the late middle to early late Miocene allowing for the deposition of monospecific or nearly monospecific assemblages of calcareous nannofossils. The youngest Miocene carbonate present at this site has an age of $\sim 9.0 \mathrm{Ma}$ and is approximately age equivalent with the youngest carbonate (except for the Holocene) on the Maurice Ewing Bank (Ciesielski et al., 1983). The early late Miocene is inferred therefore to have been the last time the Miocene polar front was significantly farther south than its modern position. This conclusion is in agreement with the consistent occurrence of ice-rafted detritus throughout the Neogene section of this site.

\section{Late Miocene Hiatus ( 2.3 m.y. duration; 8.7-6.4 Ma; $\sim 178 \mathrm{mbsf}$ in Hole 701C and 193-184 mbsf in Hole 701B)}

An upper Miocene hiatus occurs near the base of Subunit IC (Hole 701B) to the upper part of Subunit ID (Hole 701C), representing the period from $\sim 8.7$ to $6.4 \mathrm{Ma}$. This interval is commonly absent from many regions of the Southern Ocean and represents a period of widespread erosion and nondeposition in areas under the influence of AABW and CPDW (Ciesielski et al., 1983; Ciesielski, 1983, 1985; Ciesielski and Weaver, 1983). Late Miocene circum-Antarctic benthic circulation appears to have been most vigorous at this time. Ciesielski et al. (1983) inferred a major expansion of glacial regimes in Antarctica during the middle late Miocene, particularly in the west antarctic region.

\section{Latest Miocene-Quaternary ( 8.7 Ma-Present; $~ 178.0-0$} mbsf in Hole 701C, $193-184$ to 0 mbsf in Hole 701B; all of Hole 701A)

One of the most interesting aspects of the upper Miocene sequence of Site 701 is the presence of a greater than 20 -m-thick diatom ooze consisting almost entirely of the giant diatom Bruniopsis mirabilis (Fig. 7). Paleomagnetic and biostratigraphic characteristics of the Bruniopsis ooze indicate that it was deposited in a $<700,000-y r$ period during the early Messinian. The ooze has very fine laminations, lacks bioturbation, contains high organic carbon and pyrite, and is interpreted to represent deposition under anoxic to suboxic conditions. This event was probably linked to other late Miocene paleoceanographic events (e.g., antarctic glacial fluctuations, the late Miocene carbon shift, increased upwelling, sea-level regression, Messinian salinity crisis, etc.), but further speculation is not warranted until additional post-cruise studies are conducted. For more detailed discussions of the age, lithology, and fossil content of the Bruniopsis ooze, the reader is referred to the "Paleomagnetics,"
"Lithostratigraphy," and "Biostratigraphy" sections of this chapter.

The Pliocene-Quaternary sediments of Site 701 have a similar composition to age-equivalent piston cores in the region (Ledbetter and Ciesielski, 1986), which are predominantly biosiliceous but have a significant content of clay, ice-rafted detritus, and volcanic ash. Deposition at this time occurred within the Southern Ocean biosiliceous province, south or close to the ACZ. The relatively high clay content of Pliocene-Quaternary sediments is attributed to deposition from the nepheloid layer of AABW.

The relatively high sedimentation rate $(19-28 \mathrm{~m} / \mathrm{m} . \mathrm{y}$.) and nearly continuous deposition during this period is surprising considering that the site is deep enough $(4636 \mathrm{mbsl})$ to have remained under the influence of AABW. A comparison of the late Neogene sedimentation rate at this site with those of piston cores in the region (Ledbetter and Ciesielski, 1986) suggests that the main axis of AABW flow between the Islas Orcadas Rise and ridge crest occurs farther to the west. The most likely path for the northward flow of the axis of AABW is along the eastern flank of the Islas Orcadas Rise as a deep western boundary undercurrent (Ledbetter and Ciesielski, 1986; Ledbetter, 1986).

The thickness of Pliocene-Quaternary sediments at this site greatly exceeds that of the previous sites, which are under the influence of CPDW. Piston cores and comparisons of drill holes to seismic lines on subantarctic rises (Maurice Ewing Bank, Ciesielski and Wise, 1977; Northeast Georgia Rise, "Site 698" and "Site 699" chapters; Islas Orcadas Rise, Ciesielski and Ledbetter, 1986) reveal that the Pliocene-Quaternary is greatly attenuated where CPDW impinges on the elevated topography. In contrast, sedimentation rates are greater in the deeper regions $(>4100$ to $4200 \mathrm{mbsl}$ ) under the influence of AABW, except on the eastern margins of bathymetric highs where the axis of AABW flows as a deep western boundary undercurrent.

One of the most striking characteristics of late Neogene age sediments from Site 701 is the abundance of discrete and disseminated volcanic ash (for a thorough discussion, see "Lithostratigraphy" section). Post-cruise studies of the geochemical signature of these ashes will identify the most likely source area; at the present time, potential source regions include the South Sandwich Islands, the southern Andes, and the Patagonian volcanic fields. If the source region proves to be from South America, the frequency and magnitude of explosive eruptions necessary to have produced these ash concentrations would most likely have caused significant climatic feedback.

\section{REFERENCES}

Baker, P. A., 1986. Pore water chemistry of carbonate-rich sediments, Lord Howe Rise, Southwest Pacific Ocean. In Kennett, J. P., von der Borch, C. C., et al., Init. Repts. DSDP, 90: Washington (U.S. Govt. Printing Office), 1249-1256.

Baker, P. E., 1968. Comparative volcanology and petrology of the Atlantic island arcs. Bull. Volcanol., 32:189.

Barker, P. F., 1972. A spreading center in the East Scotia Sea. Earth Planet. Sci. Lett., 15:123.

Barker, P., Barber, P. L., and King, E. C., 1984. An early Miocene ridge crest-trench collision on the South Scotia Ridge near $36^{\circ} \mathrm{W}$. Tectonophysics, 102:315-332.

Barker, P. F., and Burrell, J., 1977. The opening of the Drake Passage. Mar. Geol., 25:15-34.

1982. The influence upon Southern Ocean circulation, sedimentation, and climate of the opening of the Drake Passage. Antarct. Geosci. Symp. Antarct. Geol. Geophys., 3rd, 377-385.

Barker, P., and Hill, I. A., 1981. Back-arc extension in the Scotia Sea. Philos. Trans. R. Soc. Lond. A, 300:249-262.

Barron, J. A., 1983. Latest Oligocene through early middle Miocene diatom biostratigraphy of the eastern tropical Pacific. Mar. Micropaleontol., 7:487-515. 
1985. Miocene to Holocene planktic diatoms. In Bolli, H. M., Saunders, J. B., and Perch-Nielsen, K. (Eds.), Plankton Stratigraphy: Cambridge (Cambridge Univ. Press), 763-810.

Barron, J. A., Nigrini, C. A., Pujos, A., Saito, T., Thayer, F., Thomas, E., and Weinreich, N., 1985. Synthesis of biostratigraphy, central Equatorial Pacific, Deep Sea Drilling Project Leg 85: refinement of Oligocene to Quaternary biochronology. In Mayer, L., Thayer, F., Thomas, E., et al., Init. Repts. DSDP, 85: Washington (U.S. Govt. Printing Office), 905-934.

Bayer, U., and Ott, R., 1983. Correlation of acoustic stratigraphy with cored lithology by means of physical property data for Deep Sea Drilling Project Sites 511, 513, and 514, Leg 71. In Ludwig, W. J., Krasheninnikov, V. A., et al., Init. Rept. DSDP, 71: Washington (U.S. Govt. Printing Office), 1133-1137.

Becker, K., 1985. Large-scale electrical resistivity and bulk porosity of the oceanic crust, Deep Sea Drilling Project Hole 504B, Costa Rica Rift. In Anderson, R. N., Honnorez, J., Becker, K., et al., Init. Repts. DSDP, 83: Washington (U.S. Govt. Printing Office), 419427.

Berggren, W. A., Kent, D. V., and Flynn, J. J., 1985. Paleogene geochronology and chronostratigraphy. In Snelling, N. J. (Ed.), The Geochronology of the Geological Record: Geol. Soc. London Mem., 10:141-195.

Burckle, L. H., Clarke, D. B., and Shackleton, N. J., 1978. Isochronous last-abundant-appearance datum (LAAD) of the diatom $\mathrm{He}$ midiscus karstenii in the sub-Antarctic. Geology, 6:243-246.

Chen, P. H., 1975. Antarctic radiolaria. In Hayes, D. E., Frakes, L. A., et al., Init. Repts. DSDP, 28: Washington (U.S. Govt. Printing Office), 437-514.

Ciesielski, P. F., 1975. Biostratigraphy and paleoecology of Neogene and Oligocene silicoflagellates from cores recovered during Antarctic Leg 28. In Hayes, D. E., Frakes, L. A., et al., Init. Repts. DSDP, 28: Washington (U.S. Govt. Printing Office), 625-691.

1983. The Neogene and Quaternary diatom biostratigraphy of subantarctic sediments, Deep Sea Drilling Leg 71. In Ludwig, W. J., Krasheninnikov, V. A., et al., Init. Repts. DSDP, 71: Washington (U.S. Govt. Printing Office), 635-666.

1985. Middle Miocene to Quaternary diatom biostratigraphy of Deep Sea Drilling Project Site 594, Chatham Rise, Southwest Pacific. In Kennett, J. P., von der Borch, C. C., et al., Init. Repts. DSDP, 90: Washington (U.S. Govt. Printing Office), 863-885.

Ciesielski, P. F., Ledbetter, M. T., and Ellwood, B. B., 1982. The development of Antarctic glaciation and the Neogene paleoenvironment of the Maurice Ewing Bank. Mar. Geol., 46:1-51.

Ciesielski, P. F., and Weaver, F. M., 1983. Neogene and Quaternary paleoenvironmental history of Deep Sea Drilling Project Leg 71 sediments. In Ludwig, W. A., Krasheninnikov, V. A., et al., Init. Repts. DSDP, 71: Washington (U.S. Govt. Printing Office), 461-477.

Ciesielski, P. F., and Wise, S. W., Jr., 1977. Geologic history of the Maurice Ewing Bank of the Falkland Plateau (southwest Atlantic sector of the Southern Ocean) based upon piston and drill cores. Mar. Geol., 25:175-207.

Ciesielski, P. F., Ledbetter, M. T., and Ellwood, B. B., 1983. The development of Antarctic glaciation and the Neogene paleoenvironment of the Maurice Ewing Bank. Mar. Geol., 46:1-51.

Elliot, D. H., and Emerick, C. M., 1976. Volcanic glass in some DSDP Leg 36 cores. In Barker, P., Dalziel, I.W.D., et al., Init. Repts. DSDP, 36: Washington (U.S. Govt. Printing Office), 871-876.

Federmann, A. N., Watkins, N. D., and Sigurdsson, H., 1982. Scotia Arc volcanism recorded in abyssal piston cores downwind from the islands. Antarct. Geosci, Symp. Antarct. Geol. Geophys., 3rd, 223228.

Fenner, J. M., 1984. Eocene-Oligocene planktic diatom stratigraphic in the low latitudes and the high southern latitudes. Micropaleontology, 30:319-342.

Gieskes, J. M., 1983. The chemistry of interstitial waters of deep-sea sediments: interpretation of Deep-Sea Drilling data. In Riley, J. P., and Chester, R. (Eds.), Chemical Oceanography (Vol. 8): London (Academic Press), 222-269.

Gieskes, J. M., and Lawrence, J. R., 1981. Alteration of volcanic matter in deep-sea sediments: evidence from the chemical composition of interstitial waters from deep-sea drilling cores. Geochim. Cosmochim. Acta, 45:1687-1703.
Gombos, A. M., Jr., 1984. Late Neogene diatoms and diatom oozes in the central South Atlantic. In Hsü, K. J., LaBrecque, J. L., et al., Init. Repts. DSDP, 73: Washington (U.S. Govt. Printing Office), 487-494.

Gombos, A. M., Jr., and Ciesielski, P. F., 1983. Late Eocene to early Miocene diatoms from the southwest Atlantic. In Ludwig, W. J., Krasheninnikov, V. A., et al., Init. Repts. DSDP, 71: Washington (U.S. Govt. Printing Office), 583-634.

Hays, J. D., and Opdyke, N. D., 1967. Antarctic radiolaria, magnetic reversals, and climatic change. Science, 158:1001-1011.

Hays, J. D., and Shackleton, N. J., 1976. Globally synchronous extinction of the radiolarian Stylatractus universus. Geology, 4:649-652.

Hill, I. A., and Barker, P., 1980. Evidence for back-arc extension in the central Scotia Sea. Geophys. J. R. Astron. Soc., 63:427-440.

Hsü, K. J., McKenzie, J. A., Oberhaensli, H., Weissert, H., and Wright, R. C., 1984. South Atlantic Cenozoic paleoceanography. In Hsü, K. J., LaBrecque, J. L., et al,, Init. Repts. DSDP, 73: Washington (U.S. Govt. Printing Office), 771-785.

Jenkins, D. G., 1985. Southern mid-latitude Paleocene to Holocene planktic foraminifera. In Bolli, H. M., Saunders, J. B., and PerchNielsen, K. (Eds.), Plankton Stratigraphy: Cambridge (Cambridge Univ. Press), 263-282.

Johnson, D. A., and Wick, B. J., 1982. Precision of correlation of radiolarian datum levels in the middle Miocene equatorial Pacific. Micropaleontology, 28:6-30.

Kent, D. V., and Gradstein, F., 1985. A Cretaceous and Jurassic geochronology. Geol. Soc. Am. Bull., 96:1419-1427.

Kim, W. H., and Barron, J. A., 1986. Diatom biostratigraphy of the upper Oligocene to lowermost Miocene San Gregorio Formation, Baja California Sur, Mexico. Diatom Res., 1:169-187.

LaBrecque, J. L. (Ed.), 1986. South Atlantic Ocean and Adjacent Continental Margin Atlas 13: Ocean Margin Drilling Program Reg. Atlas Ser., 13.

Lamb, H. H., 1972. Climate: Present, Past and Future: London (Methuen).

Ledbetter, M. T., 1986. Bottom-current pathways in the Argentine Basin revealed by mean silt particle size. Nature, 321:423-425.

Ledbetter, M. T., and Ciesielski, P. F., 1982. Bottom current erosion along a traverse in the South Atlantic. Mar. Geol., 46:329-341. 1986. Post-Miocene disconformities and paleoceanography in the Atlantic sector of the Southern Ocean. Palaeogeogr. Palaeoclimatol. Palaeoecol., 52:184-214.

Ling, H. Y., 1973. Silicoflagellates and ebridians from Leg 29. In Creager, J. S., Scholl, D. W., et al., Init. Repts. DSDP, 19: Washington (U.S. Govt. Printing Office), 751-775.

Mankinen, E. A., and Dalrymple, G. B., 1979. Revised geomagnetic timescale for the interval 0-5 m.y. B.P. J. Geophys. Res., 84:615626.

Martini, E., 1971. Standard Tertiary and Quaternary calcareous nannoplankton zonation. In Farinacci, A. (Ed.), Proc. Planktonic Conf. II Rome 1970: Rome (Technoscienze), 2:739-785.

Martini, E., and Müller, C., 1986. Current Tertiary and Quaternary calcareous nannoplankton stratigraphy and correlations. Newsl. Stratigr., 16:99-112.

McCollum, D. W., 1975. Diatom stratigraphy of the Southern Ocean. In Hayes, D. E., Frakes, L. A., et al., Init. Repts. DSDP, 28: Washington (U.S. Govt. Printing Office), 515-572.

McGowran, B., 1986. Cainozoic oceanic and climatic events: the IndoPacific foraminiferal biostratigraphic records. Palaeogeogr. Palaeoclimatol. Palaeoecol., 55:247-265.

Mikkelsen, N., 1977. On the origin of Ethmodiscus ooze. Mar. Micropaleontol., 2:35-46.

Miller, K. G., Mountain, G. S., and Tucholke, B. E., 1985. Oligocene glacio-eustacy and erosion on the margins of the North Atlantic. Geology, 13:10-13.

Nobes, D. C., Law, L. K., and Edwards, R. N., 1986. The resistivity and porosity of the sediment and fractured basalt layers near the Juan de Fuca Ridge. Geophys. J. R. Astron. Soc., 87:287-319.

Perch-Nielsen, K., 1975. Late Cretaceous to Pleistocene archaeomonads, ebridians, endoskeletal dinoflagellates, and other siliceous microfossils from the subantarctic Southwest Pacific, DSDP Leg 29. In Kennett, J. P., Houtz, R. E., et al., Init. Repts. DSDP: Washington (U.S. Govt. Printing Office), 677-721. 
1985. Cenozoic calcareous nannofossils. In Bolli, H. M., Saunders, J. B., and Perch-Nielsen, K. (Eds.), Plankton Stratigraphy: Cambridge (Cambridge Univ. Press), 427-554.

Schlanger, S. O., and Premoli Silva, I., 1986. Oligocene sea-level falls recorded in mid-Pacific atoll and archipelagic apron settings. Geology, 14:392-395.

Shaw, C. A., and Ciesielski, P. F., 1983. Silicoflagellate biostratigraphy of middle Eocene to Holocene subantarctic sediments recovered by Deep Sea Drilling Project Leg 71. In Ludwig, W. J., Krasheninnikov, V. A., et al., Init. Repts. DSDP, 71: Washington (U.S. Govt. Printing Office), 687-737.

Shaw, D. M., Watkins, N. D., and Huang, T. C., 1974. Atmospherically transported volcanic glass in deep sea sediments: theoretical considerations. J. Geophys. Res., 79:3087-3094.

Vail, P. R., Mitchum, R. M., and Thompson, S., III, 1977. Global cycles of relative changes in sea level. In Payton, C. E. (Ed.), Seismic
Stratigraphy: Applications to Hydrocarbon Exploration: AAPG Mem., 26:83-97.

Weaver, F. M., 1983. Cenozoic radiolarians from the southwest Atlantic, Falkland Plateau region, Deep Sea Drilling Project Leg 71. In Ludwig, W. J., Krasheninnikov, V. A., et al., Init. Repts. DSDP, 71: Washington (U.S. Govt. Printing Office), 667-686.

Weaver, F. M., and Gombos, A. M., Jr., 1981. Southern high latitude diatom biostratigraphy. In Warme, J. E., Douglas, R. G., and Winterer, E. L. (Eds.), The Deep Sea Drilling Project: A Decade of Progress: Spec. Publ. Soc. Econ. Paleontol. Mineral., 32:445-470.

Wyllie, M.R.J., Gregory, A. R., and Gardner, L. W., 1956. Elastic wave velocities in heterogeneous and porous media. Geophysics, 21:4170 .

\section{Ms 114A-108}



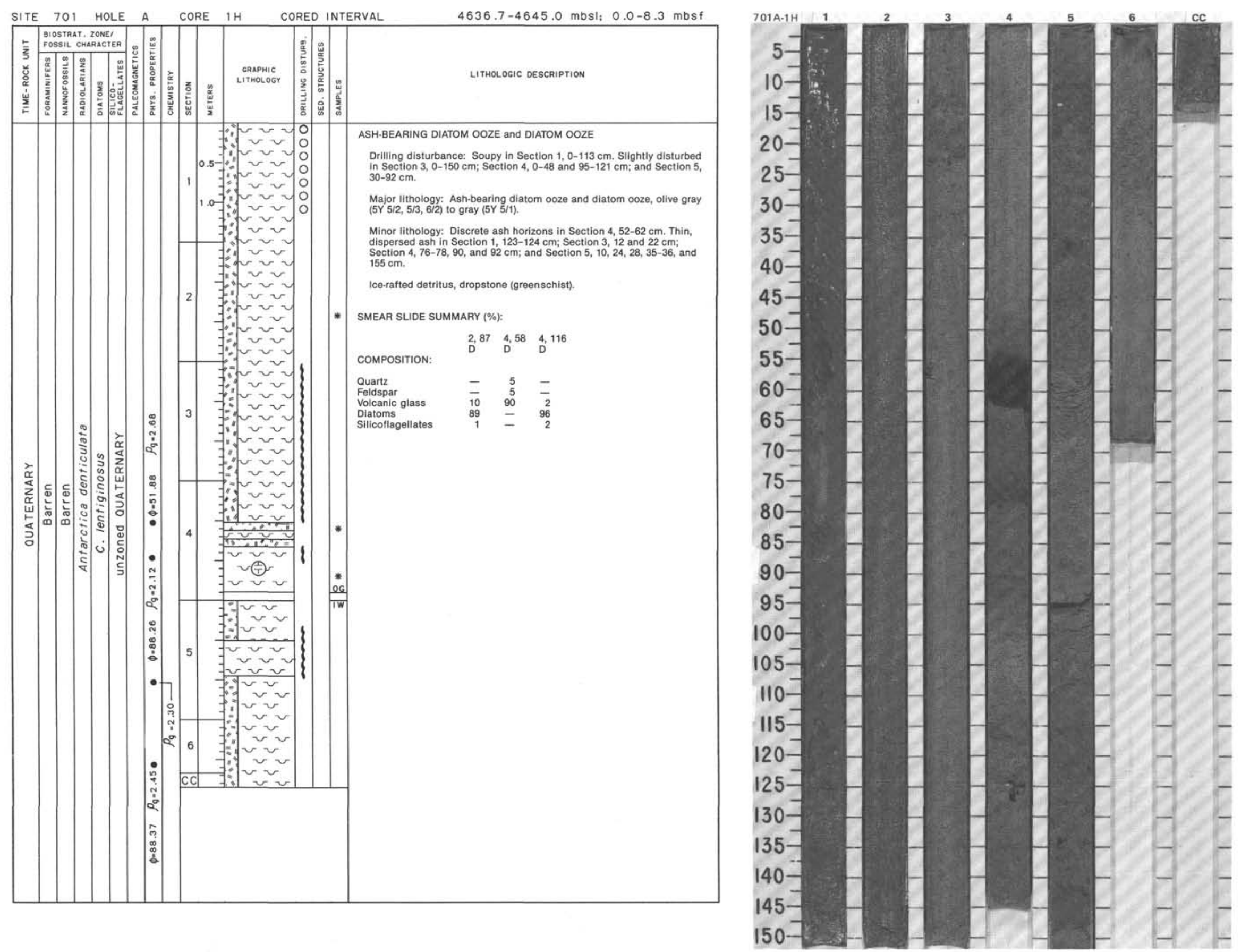

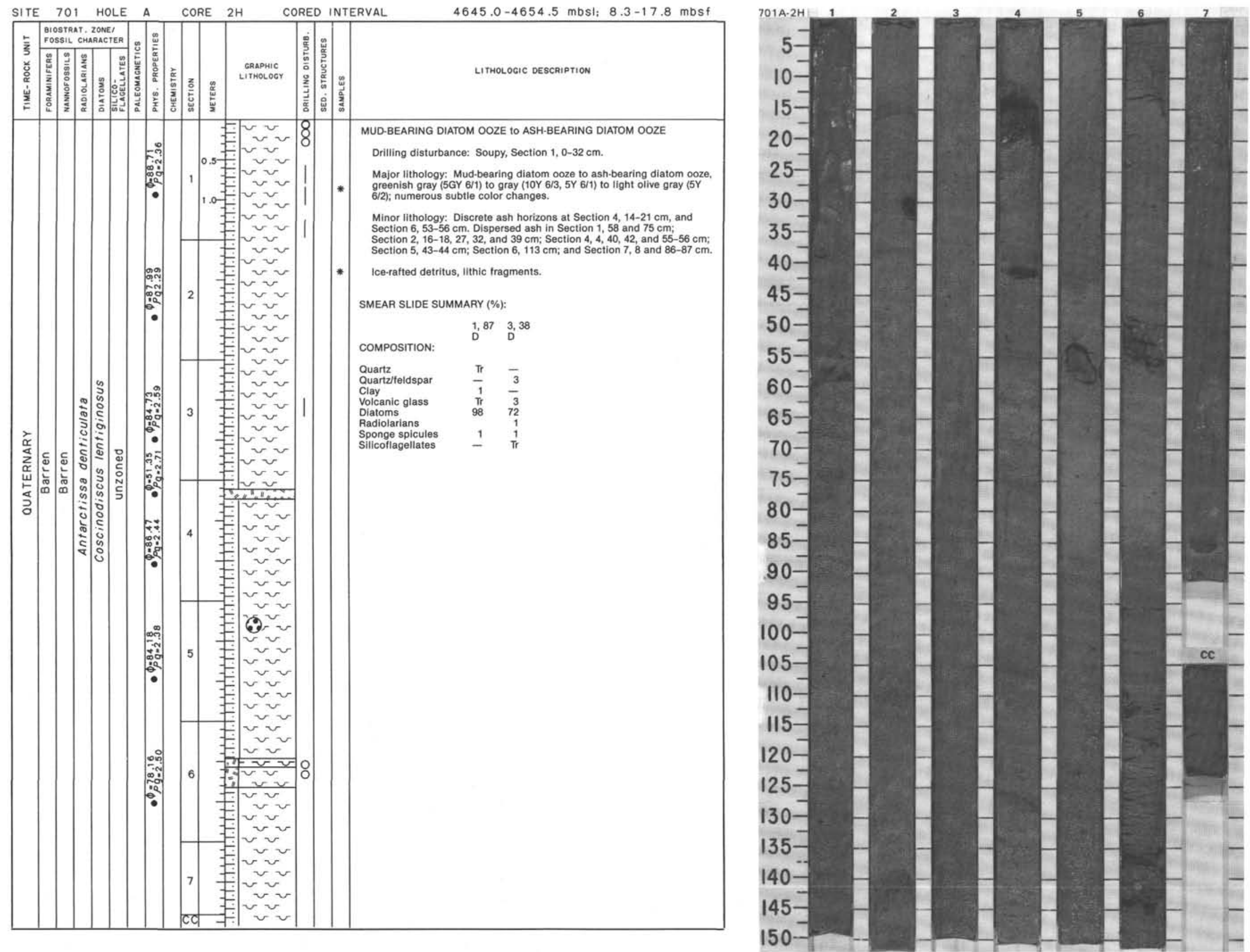

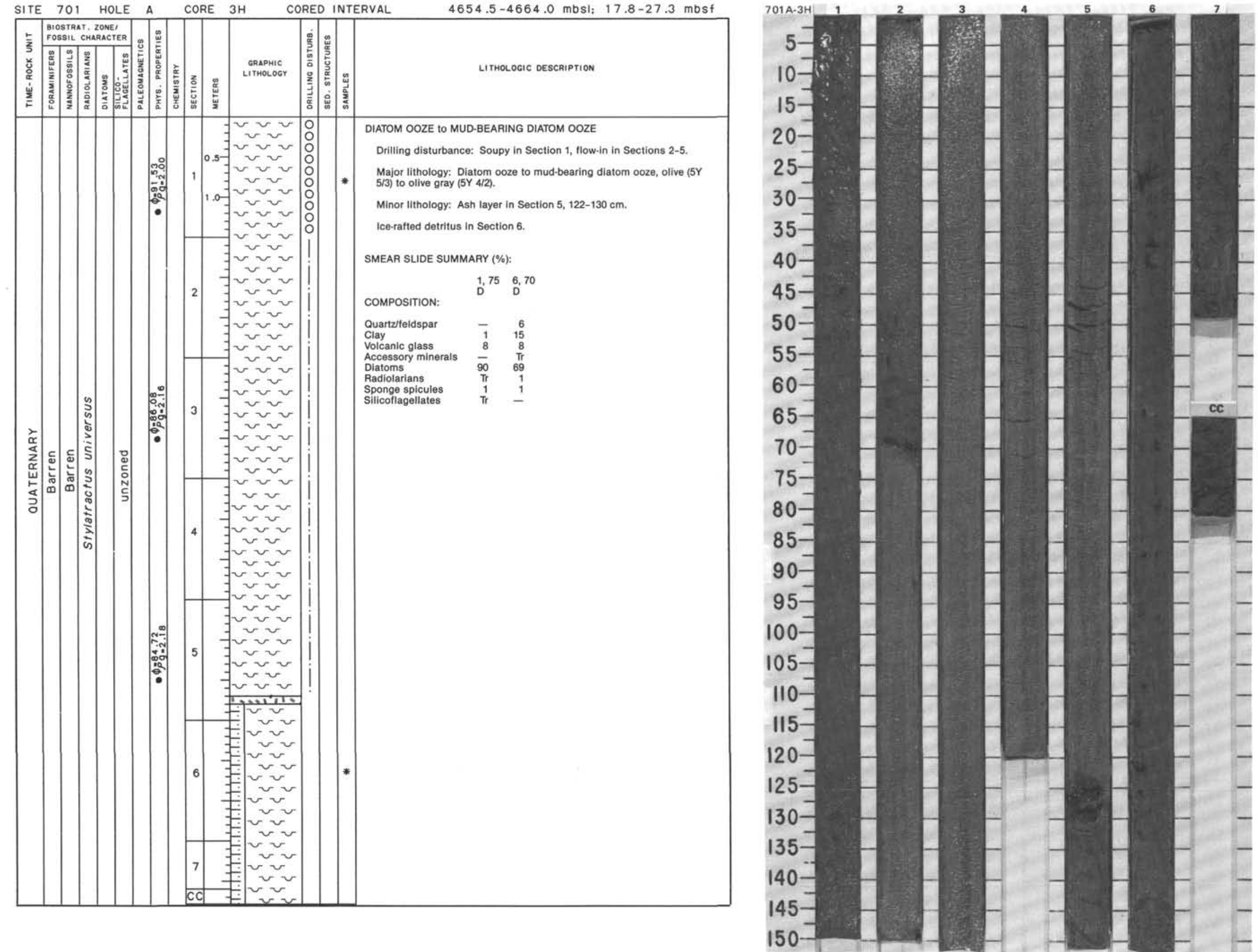


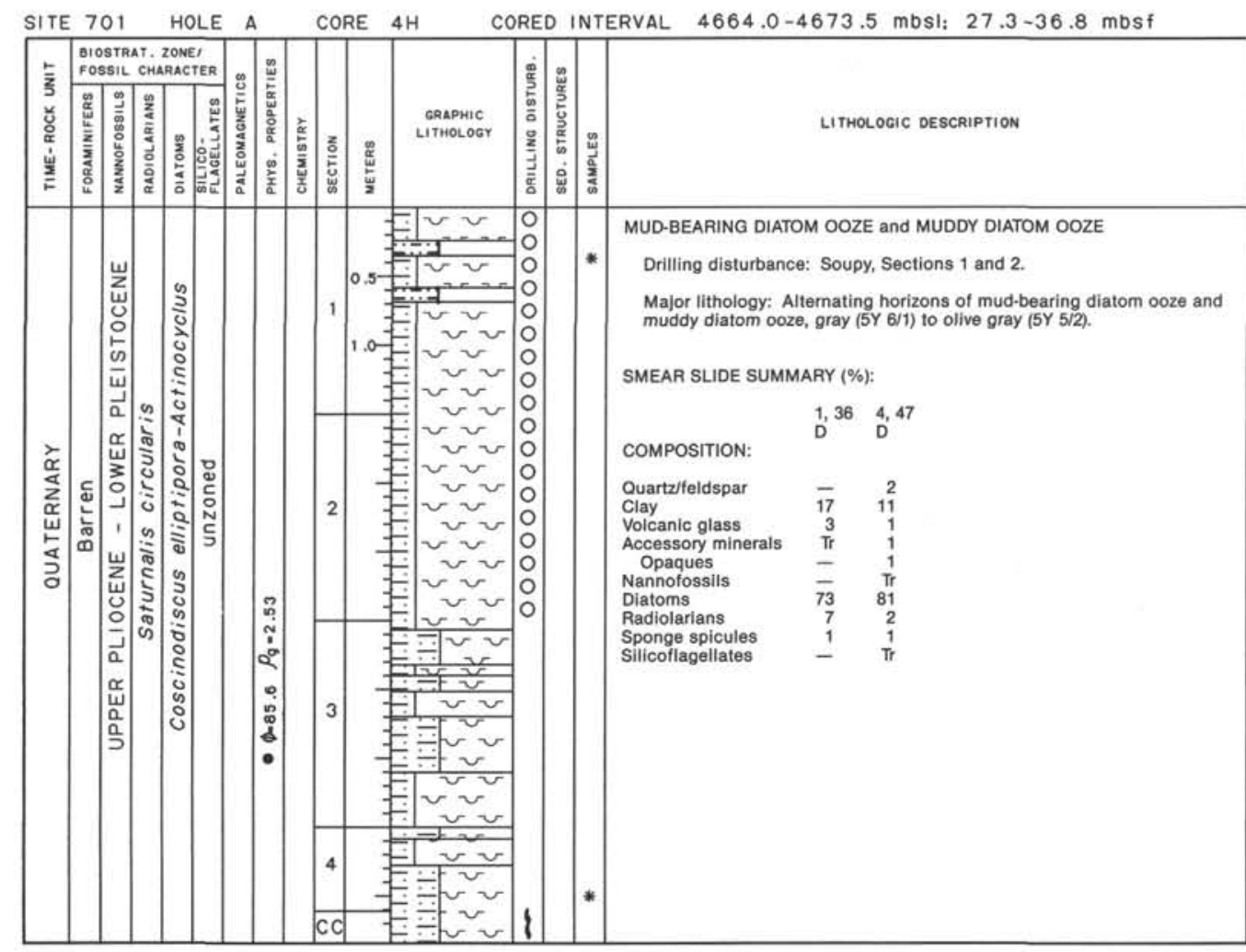

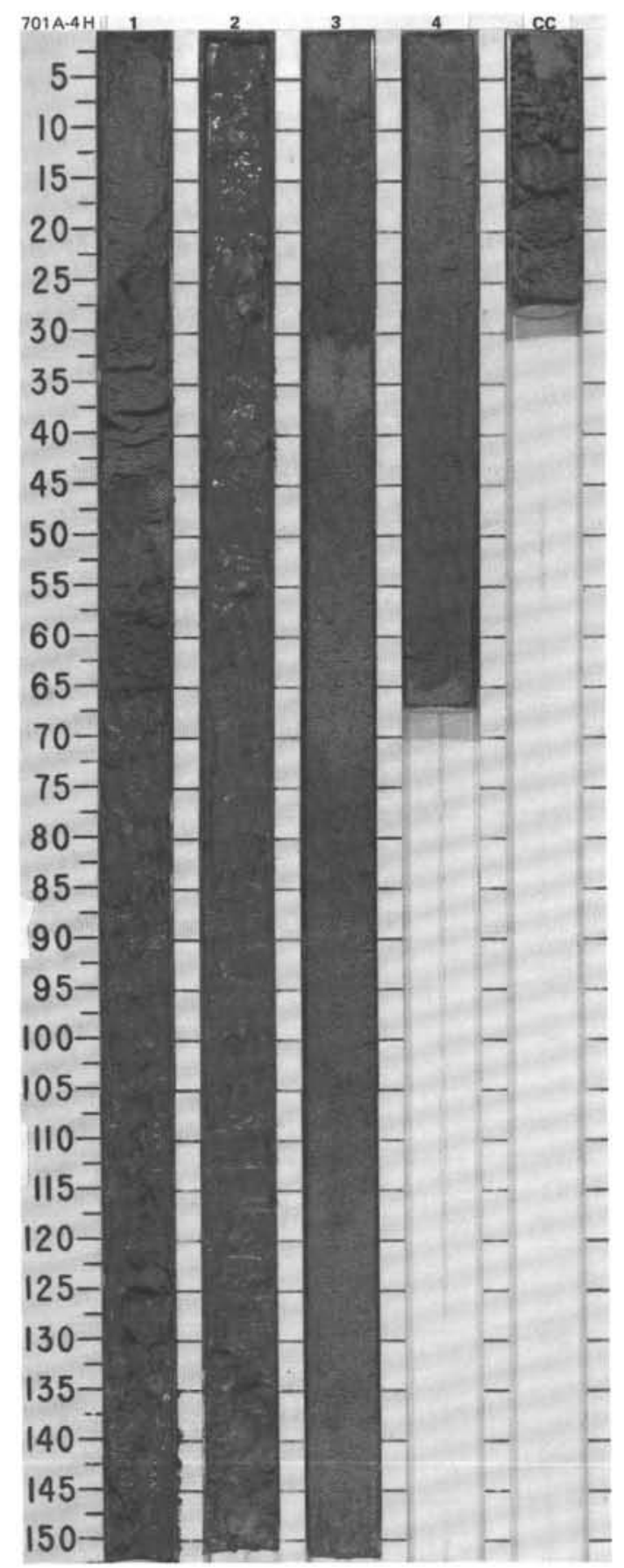



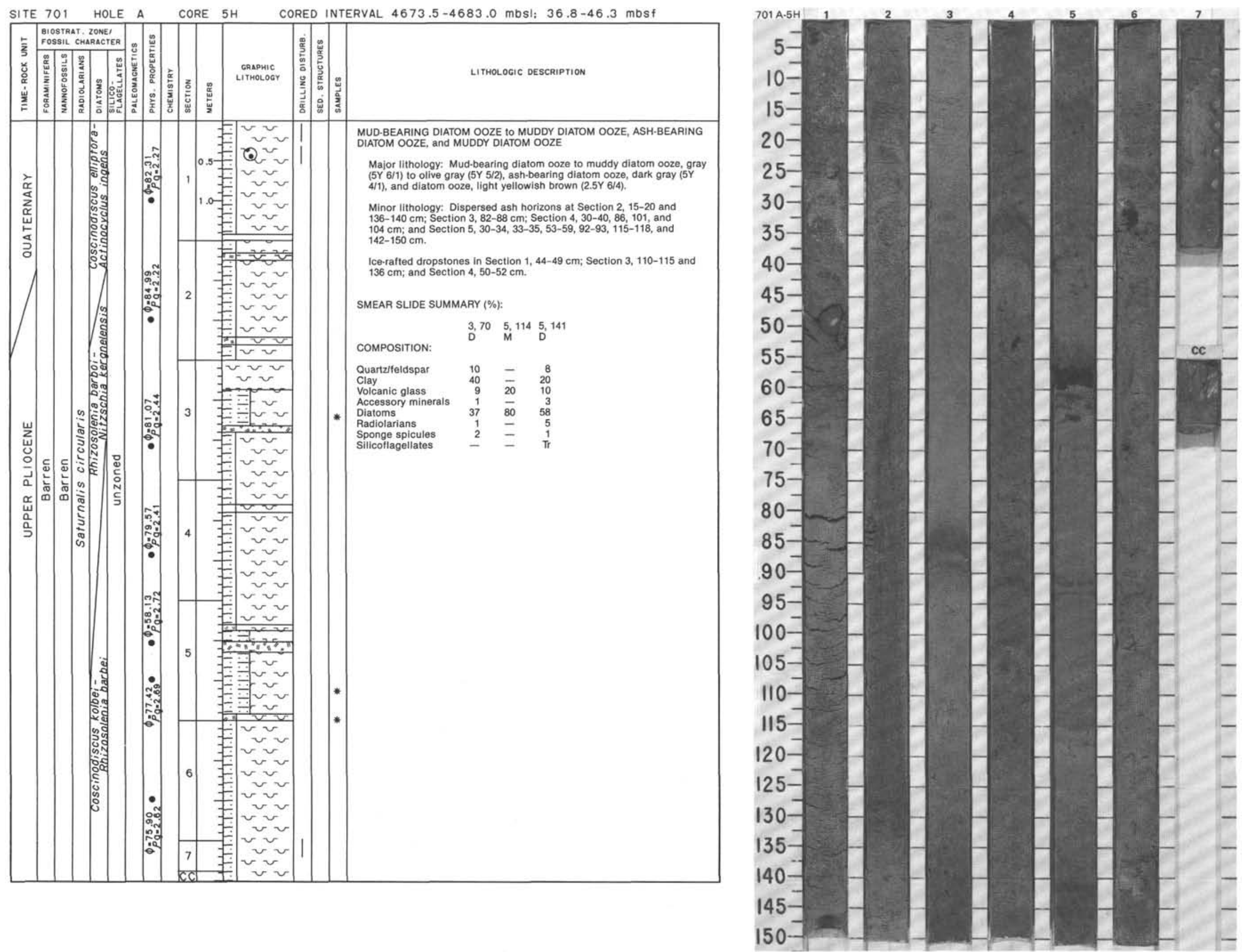


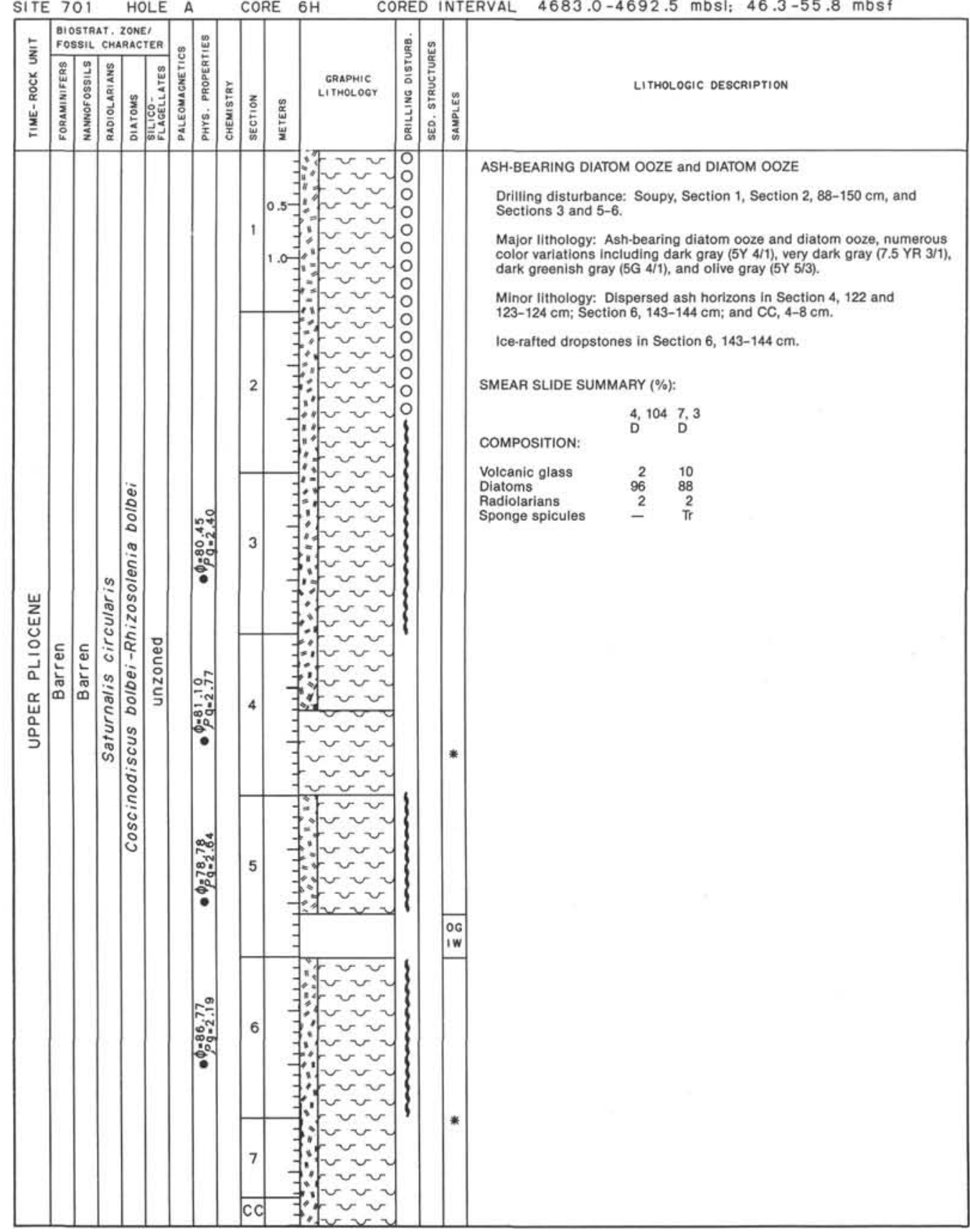

송

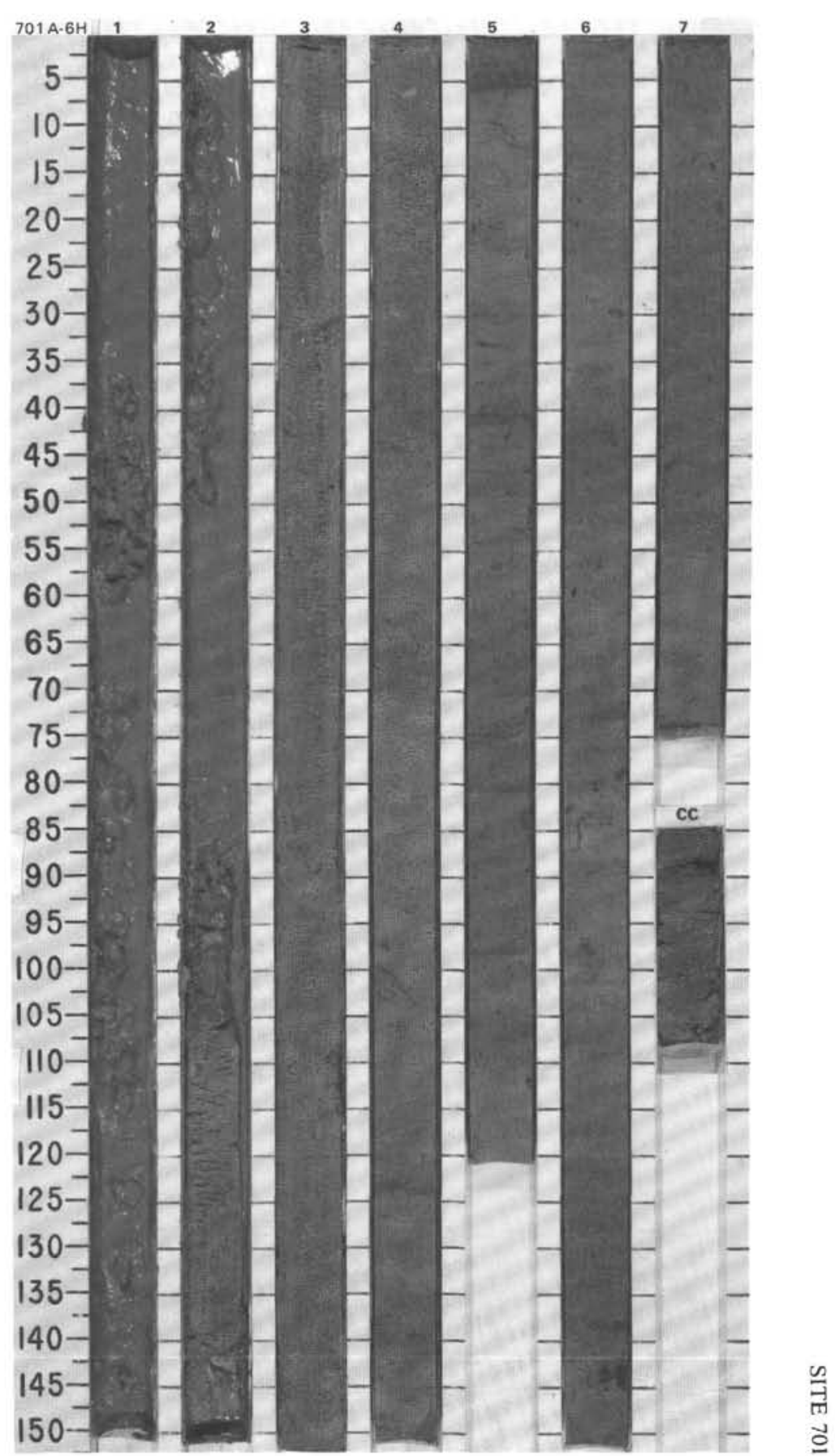



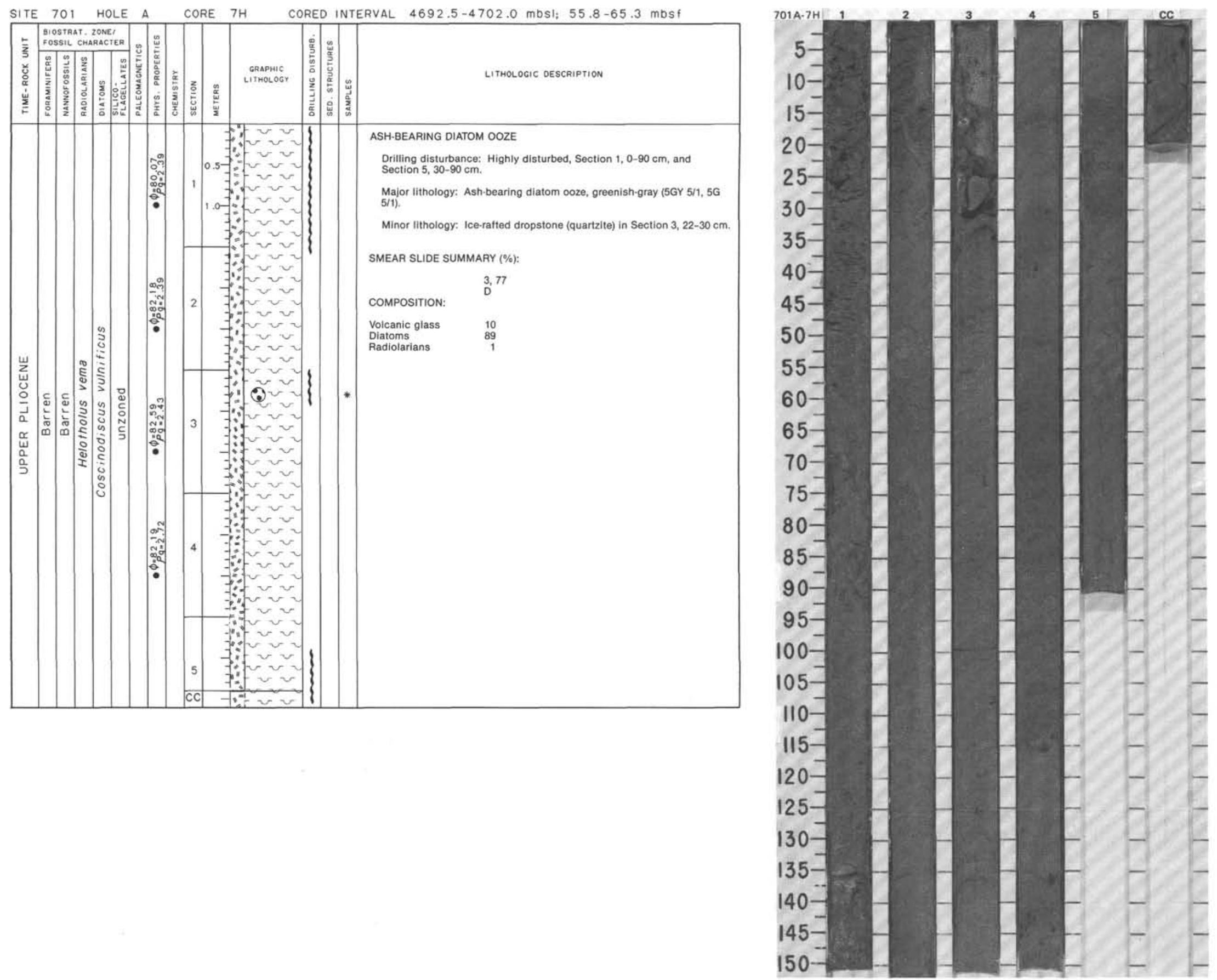

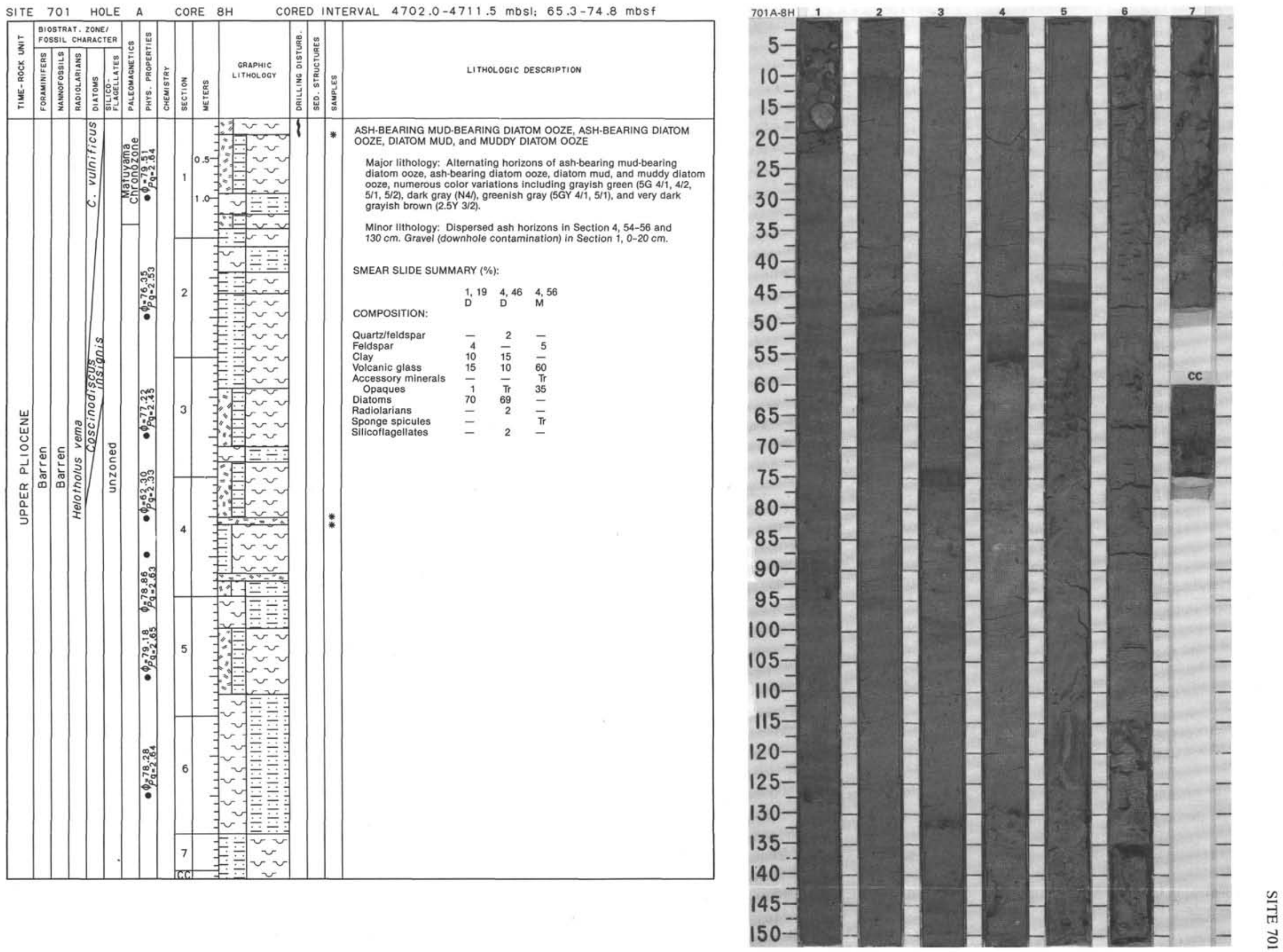

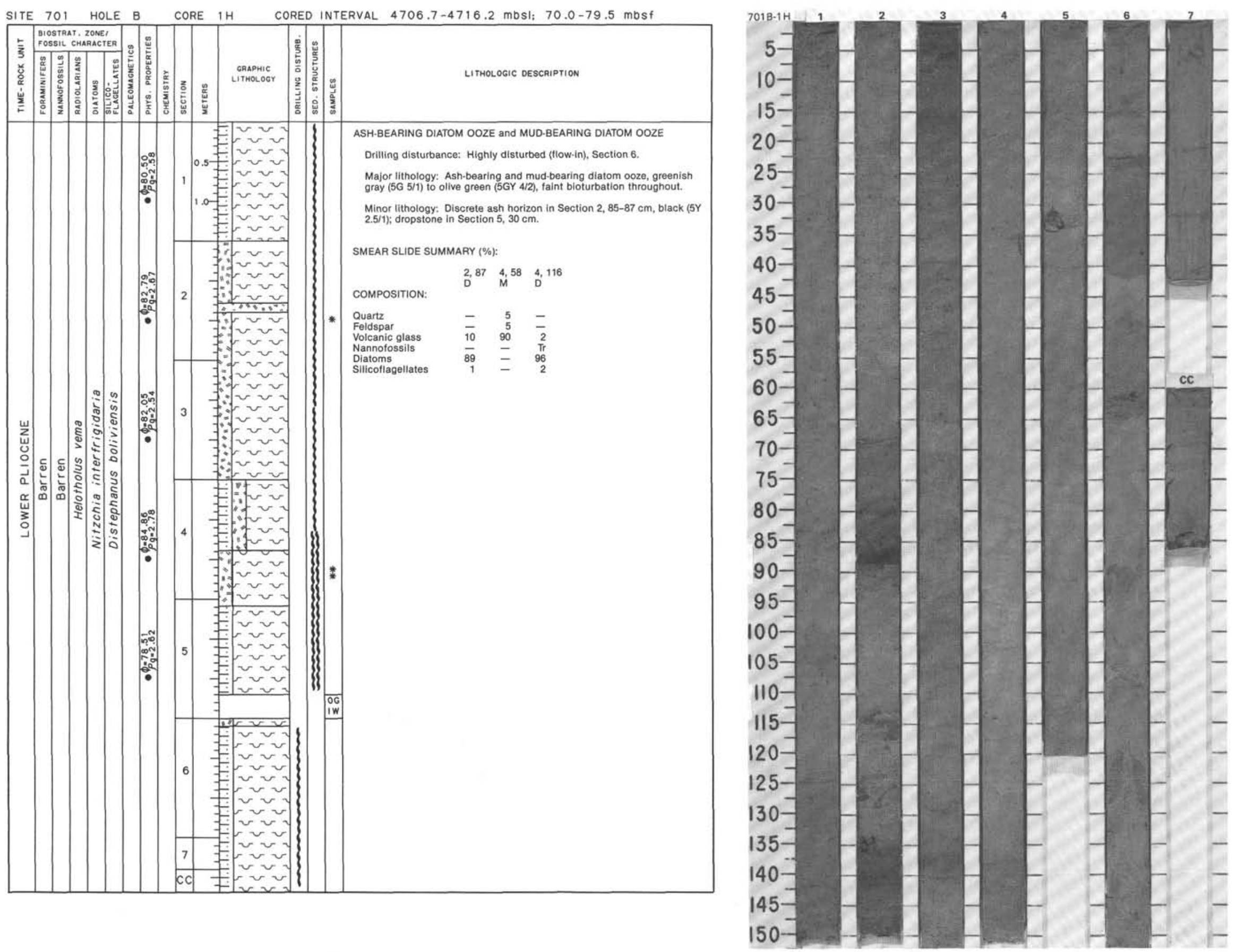


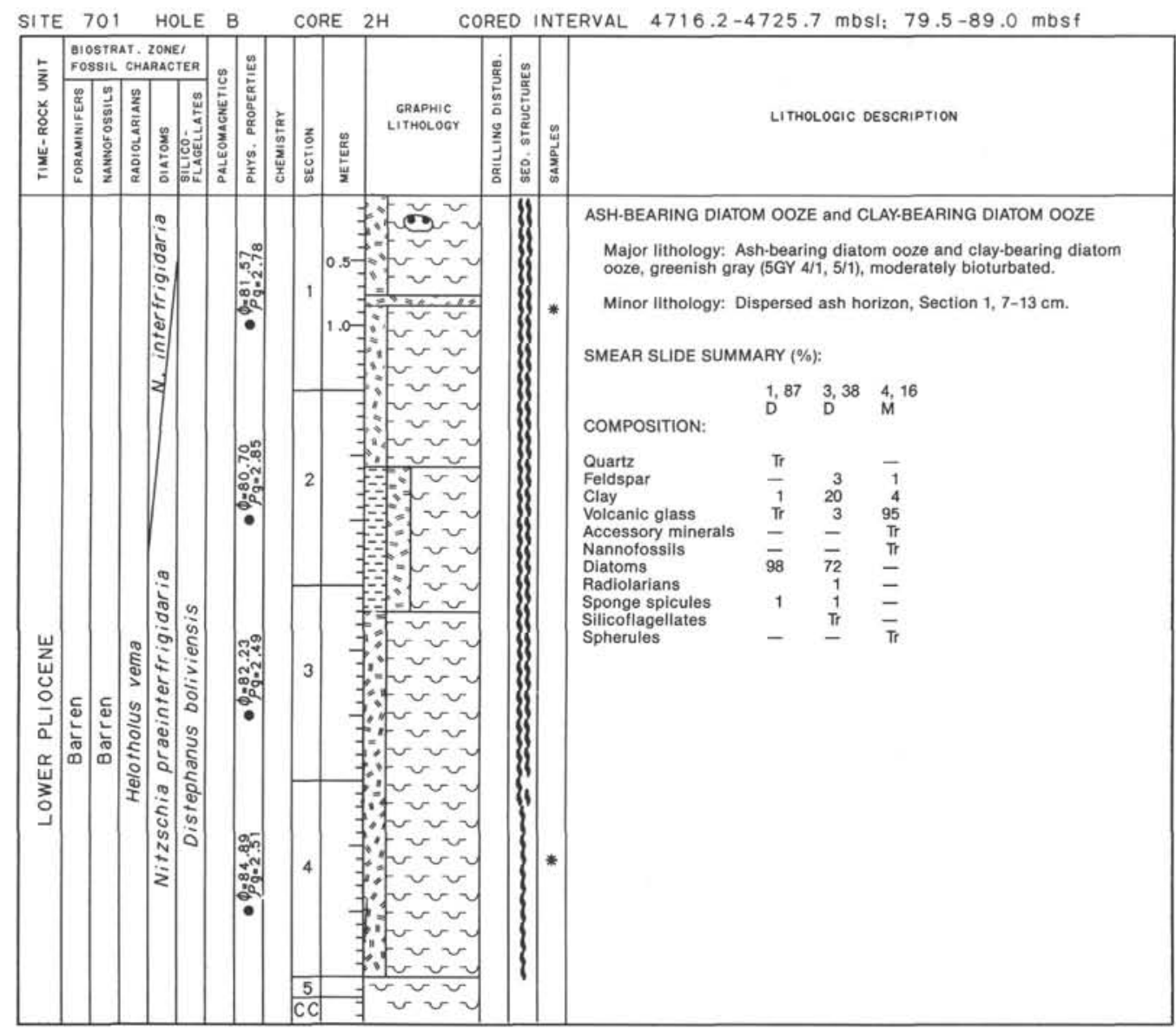

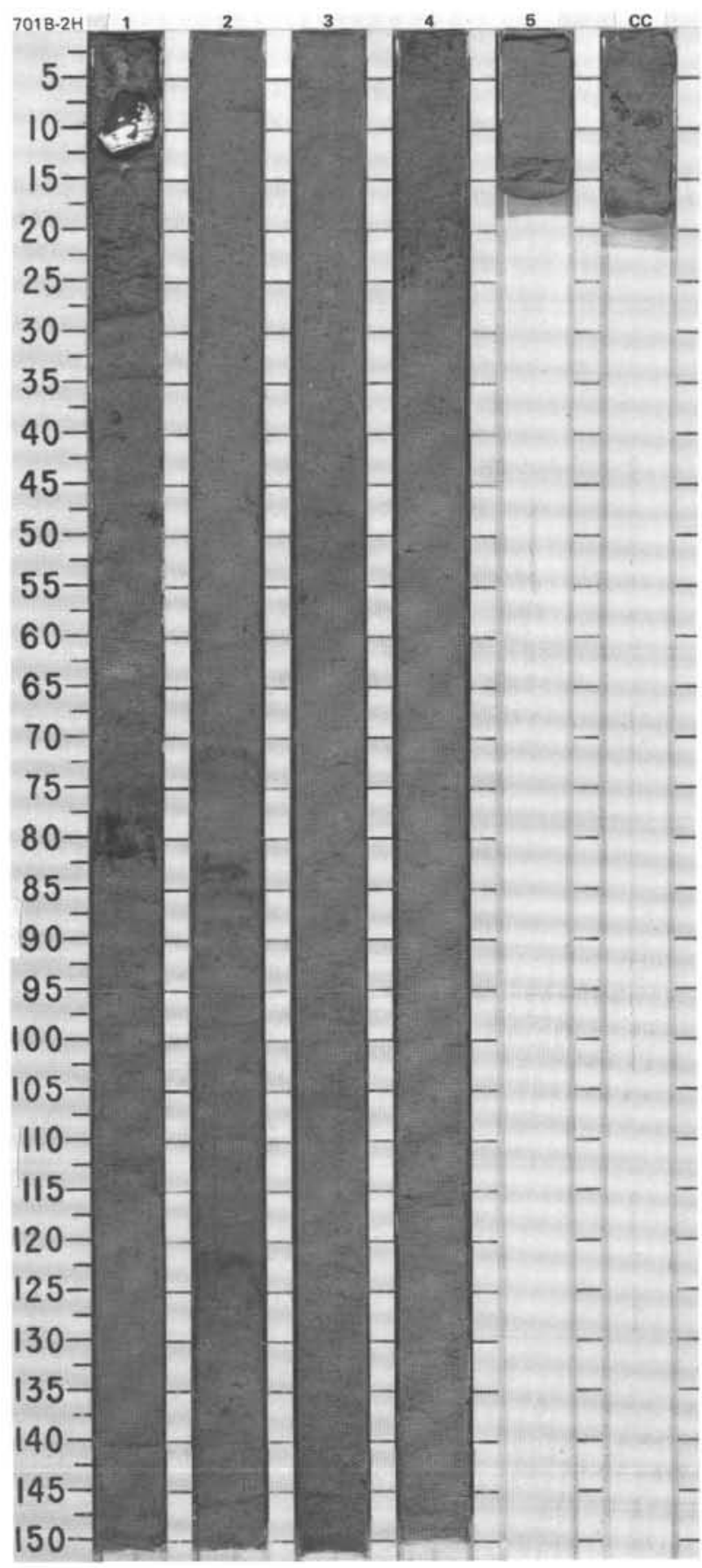



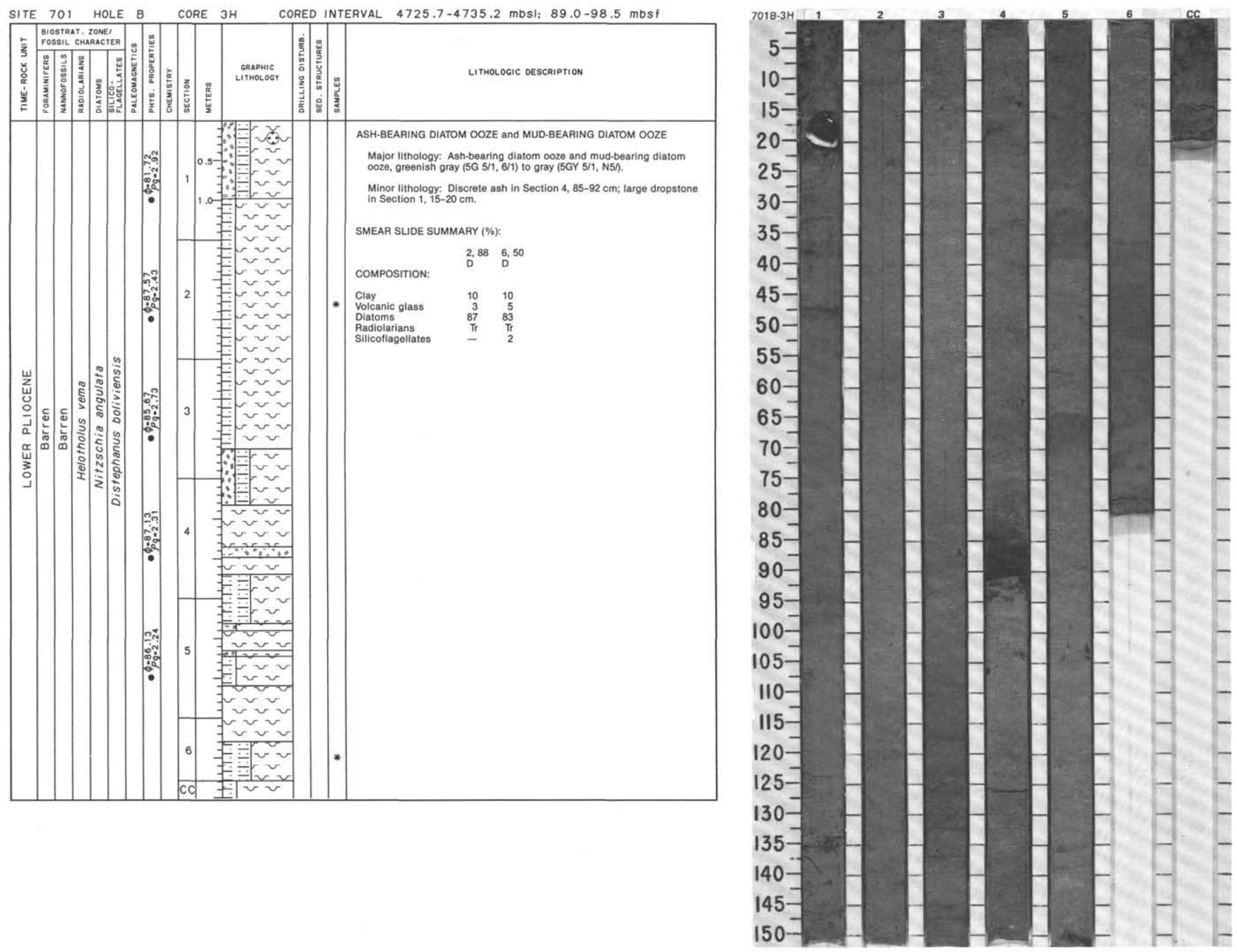


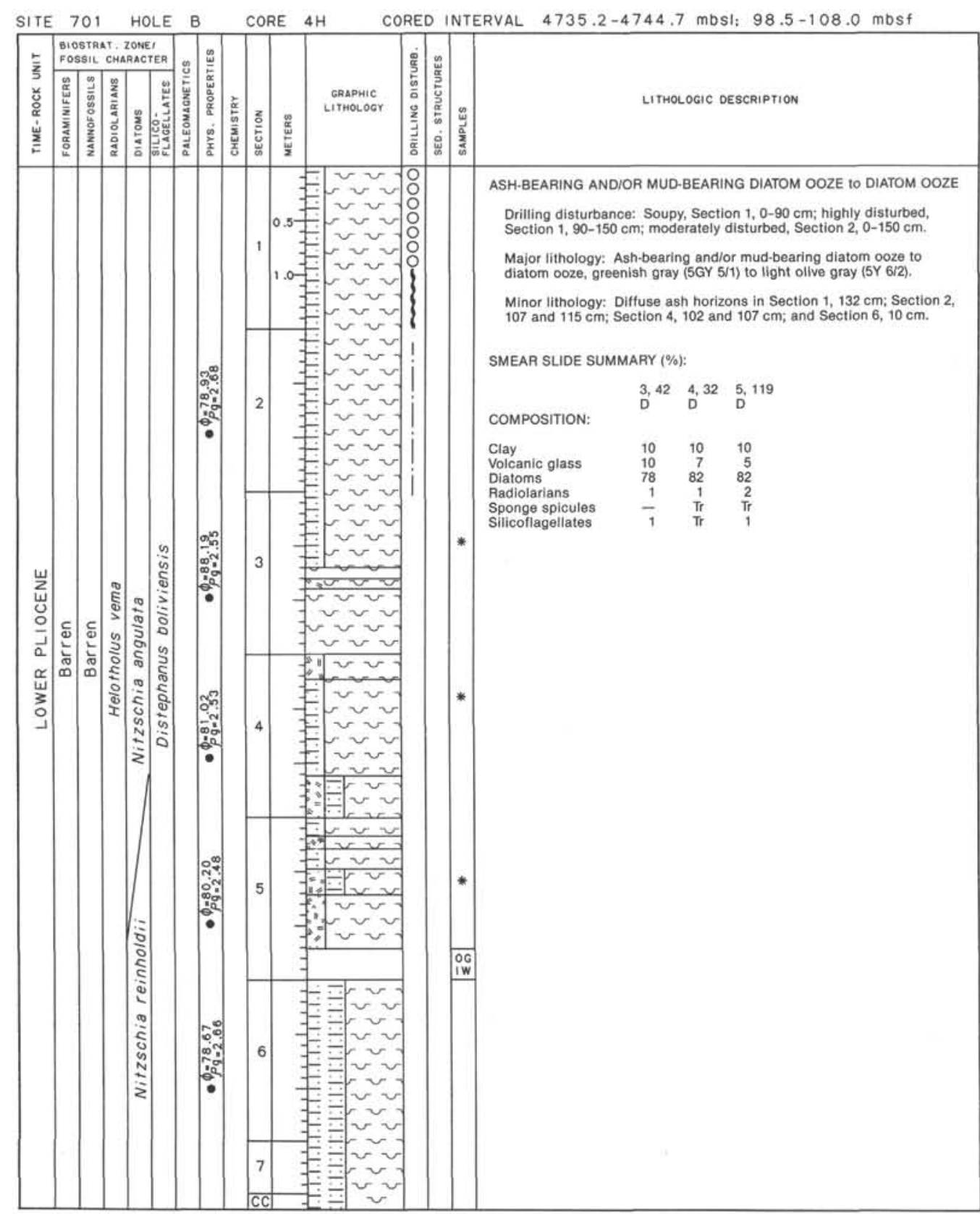

式

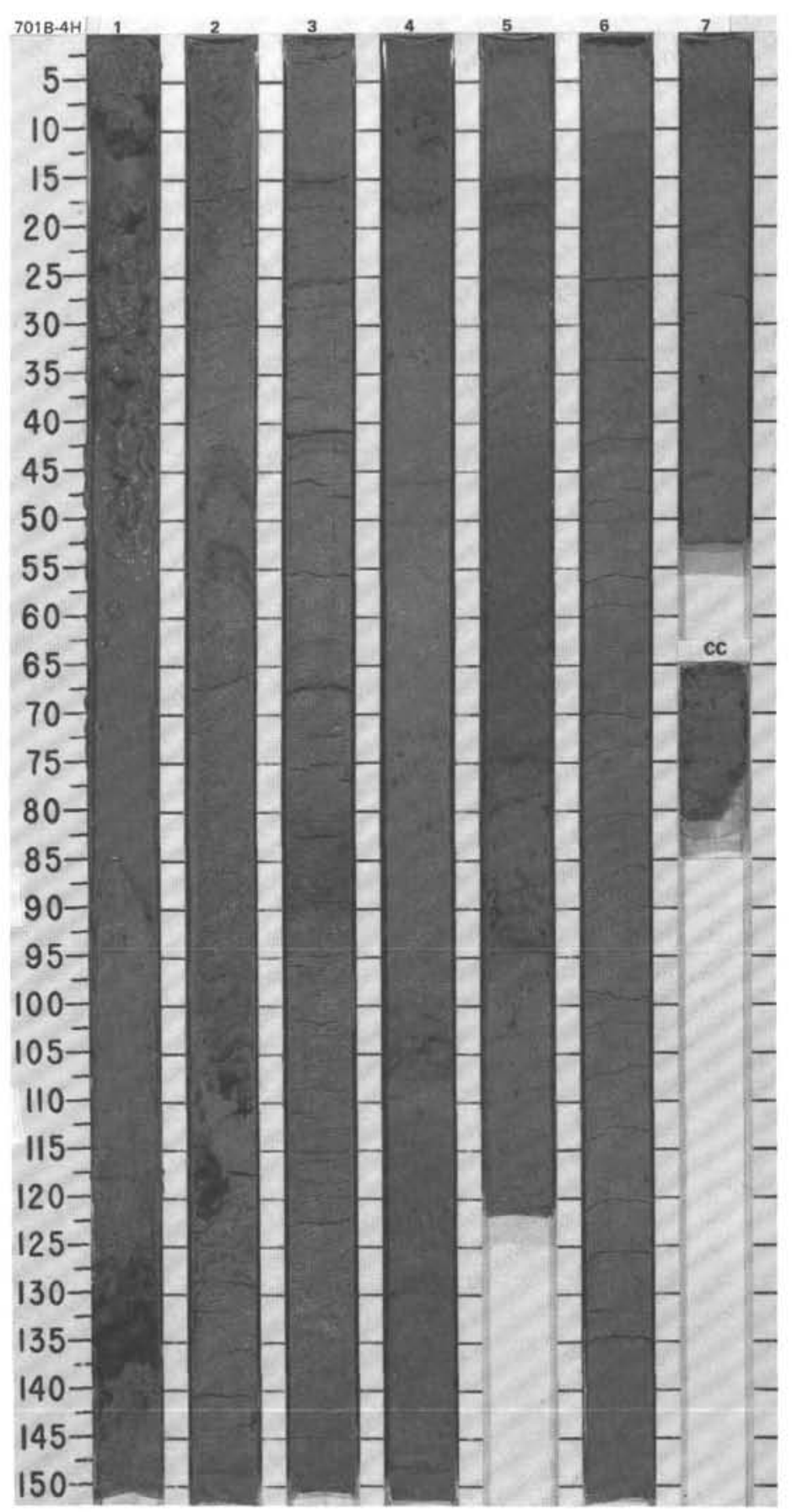

节 

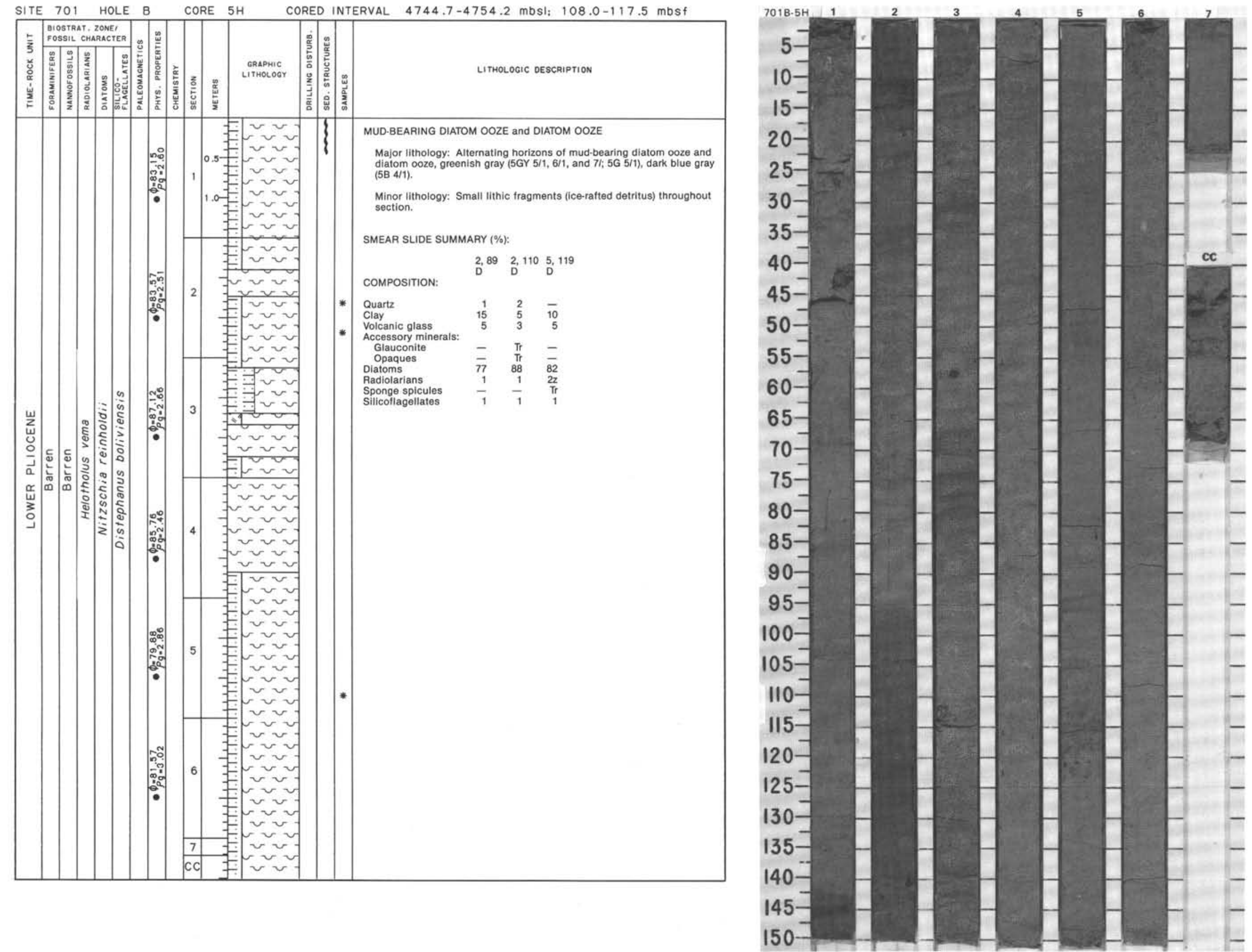


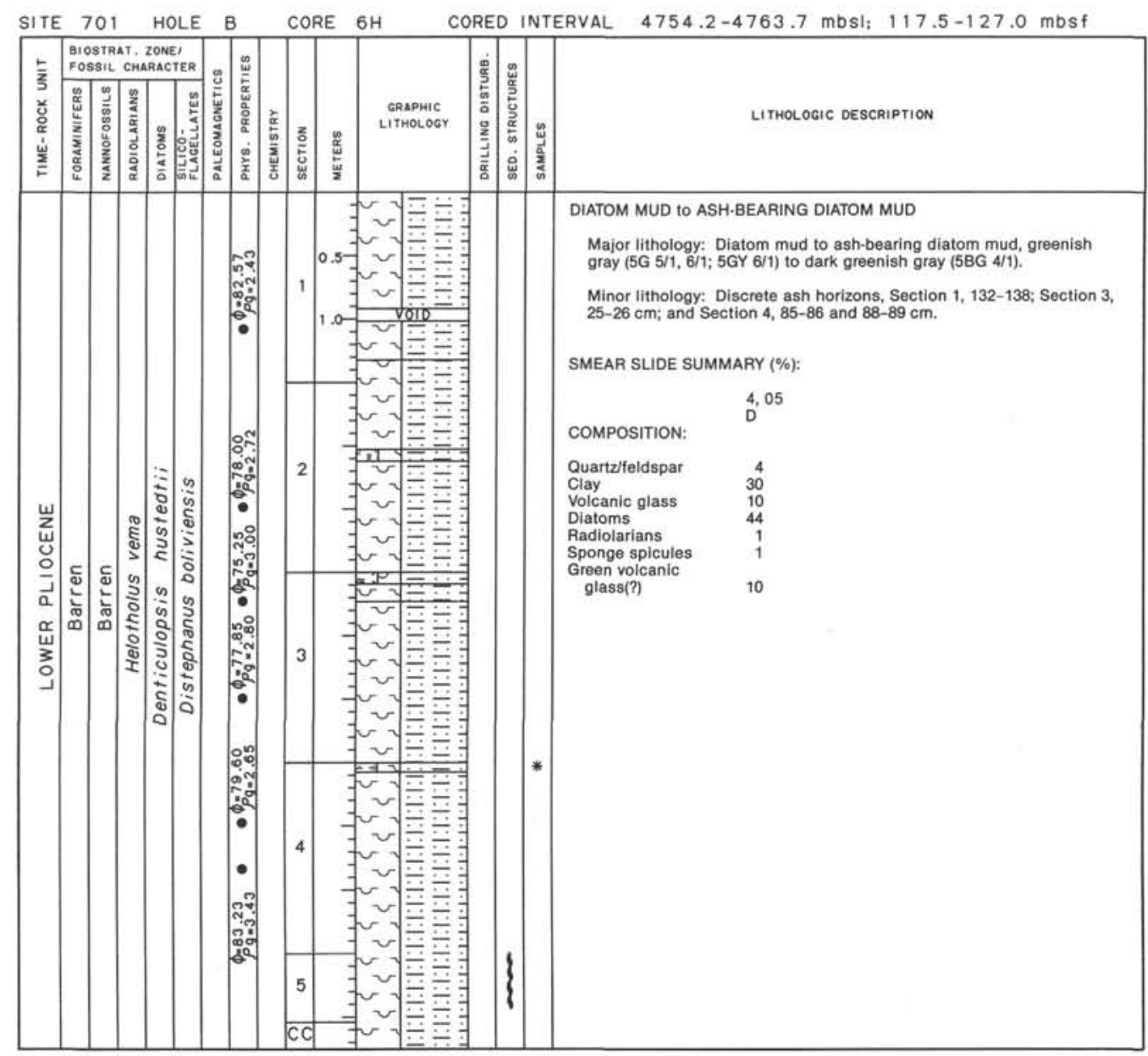

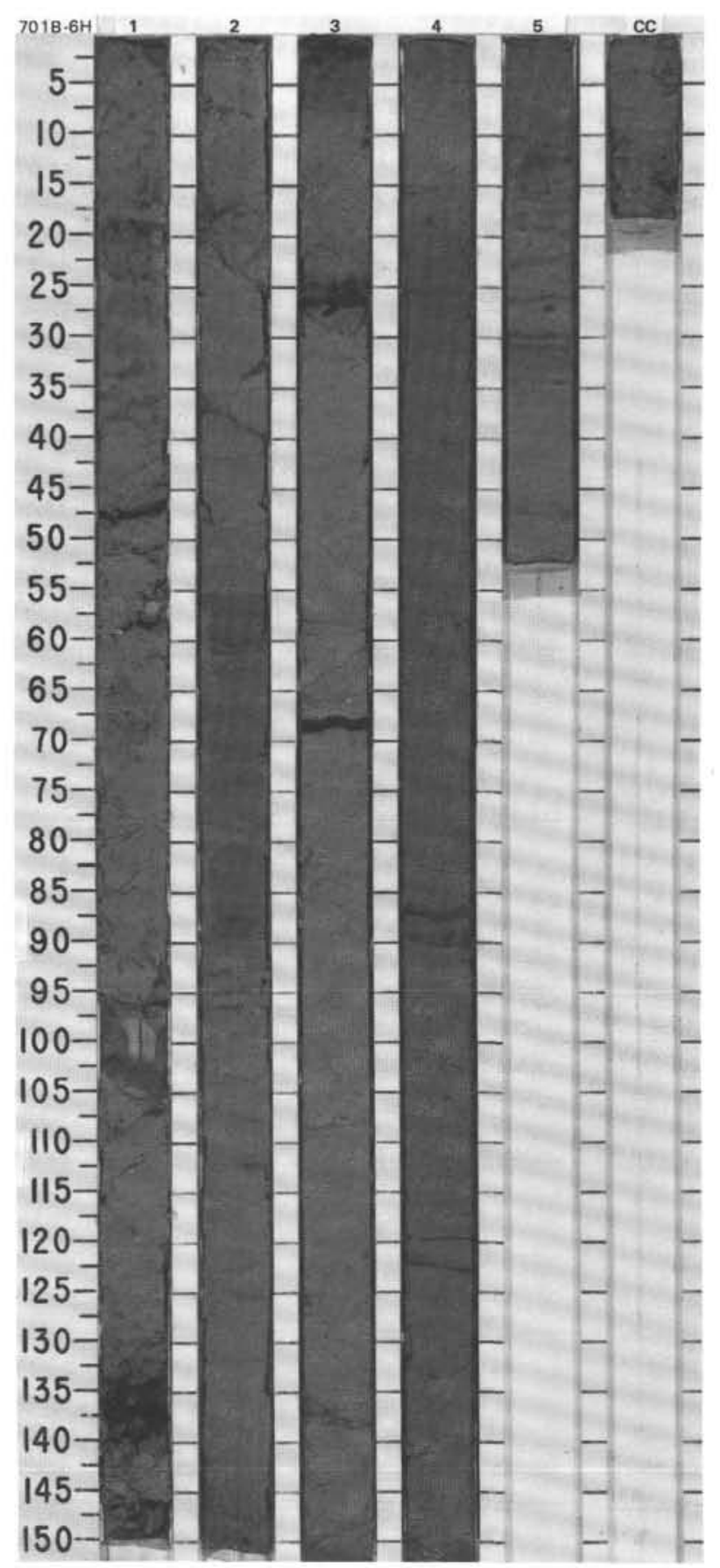



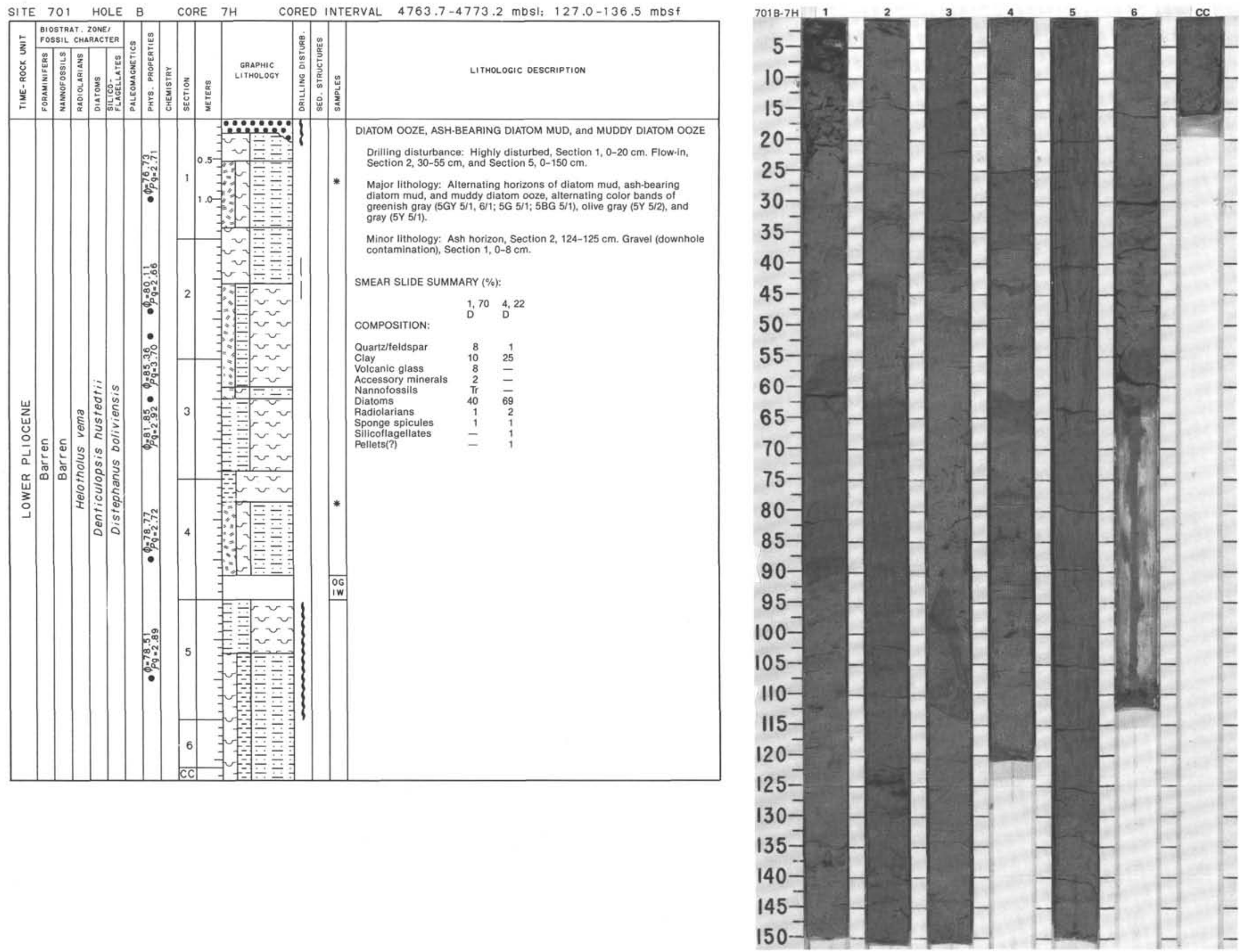

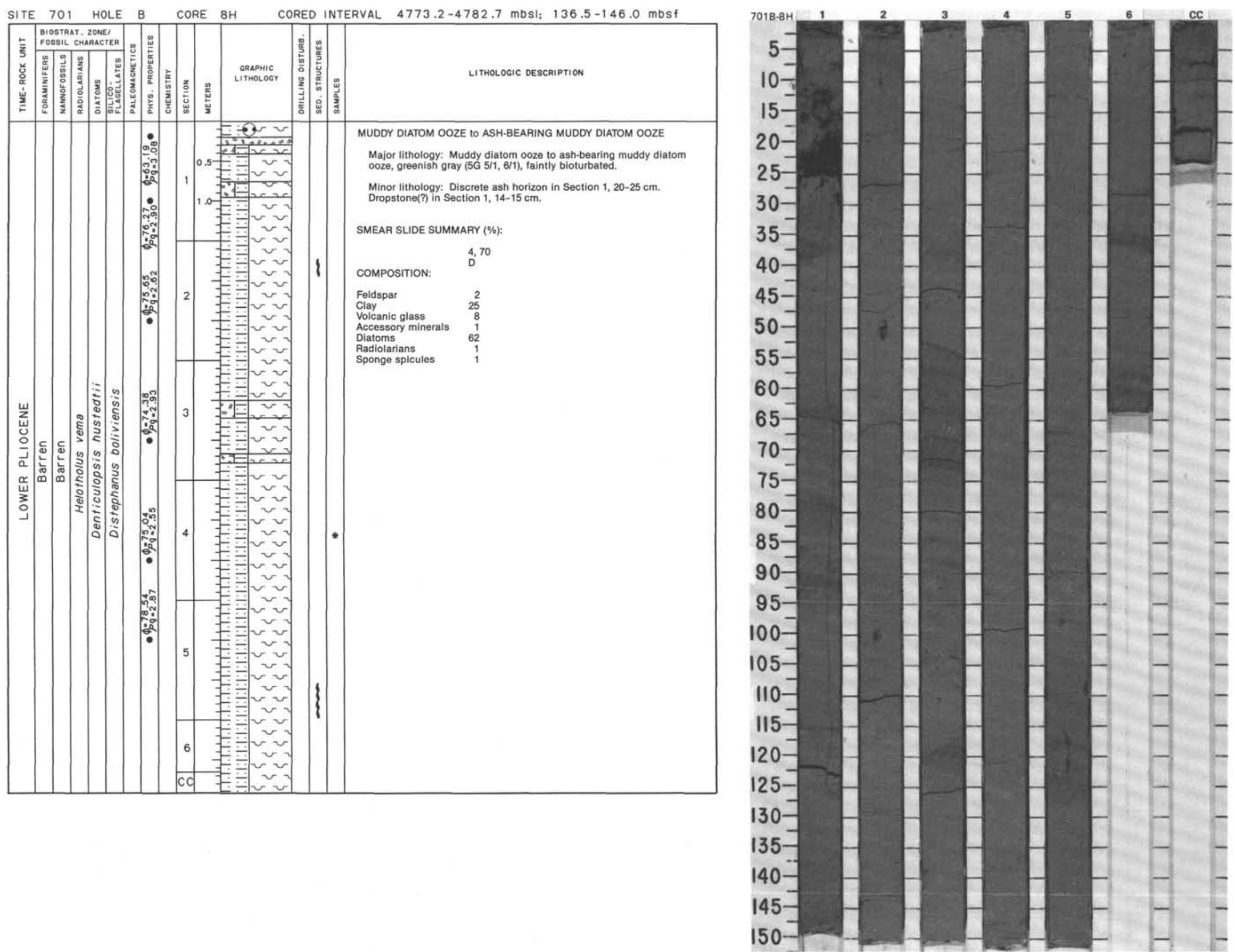

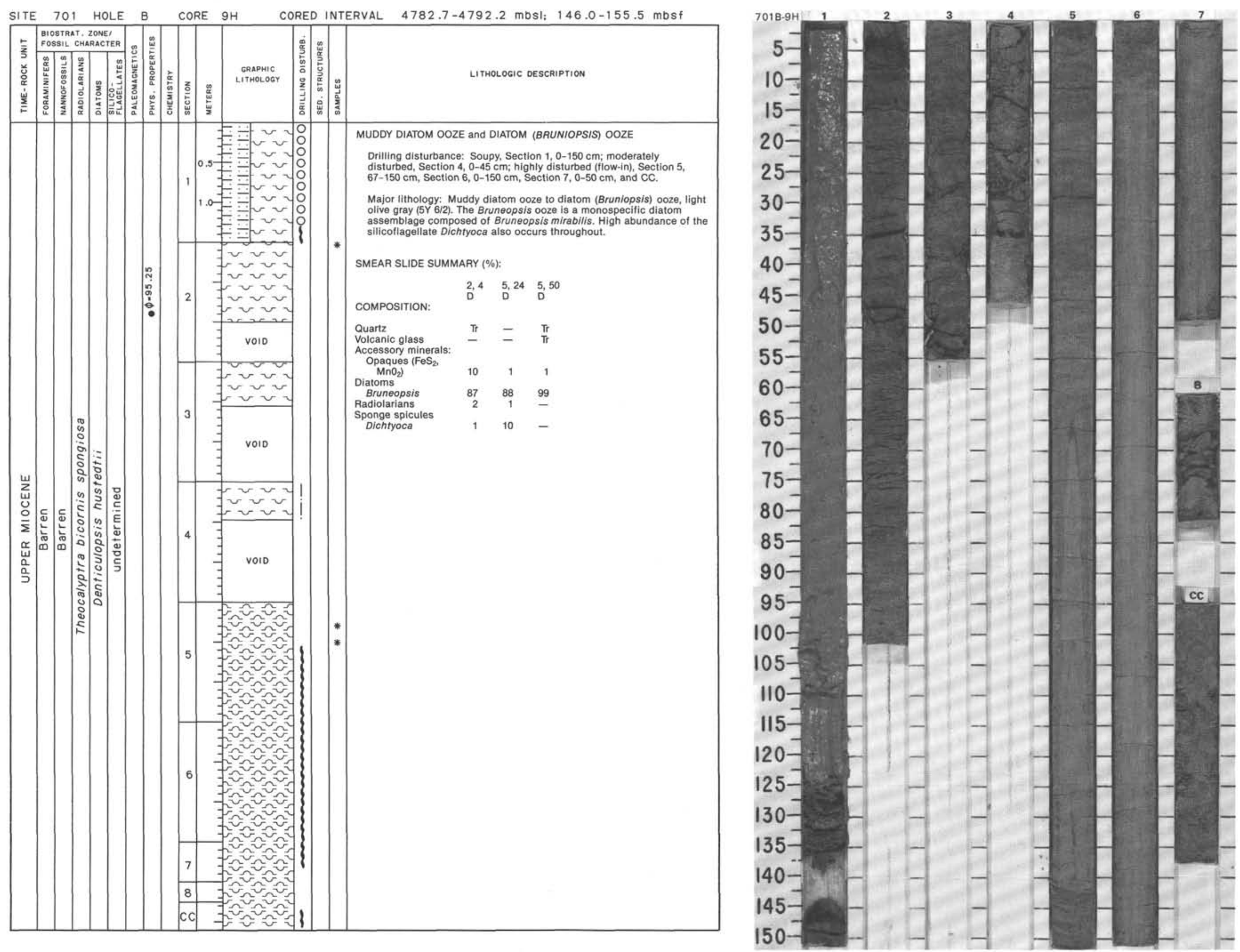

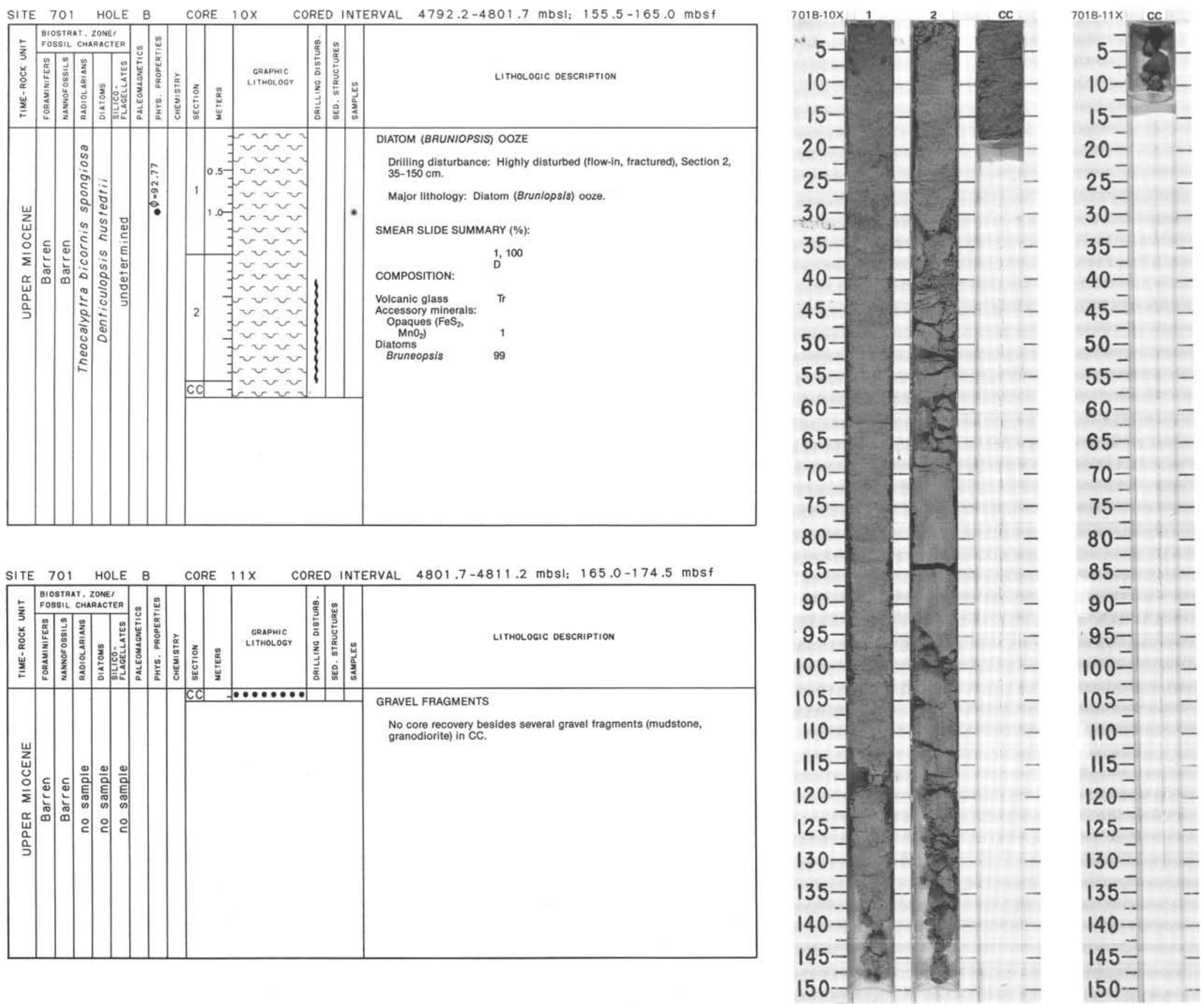


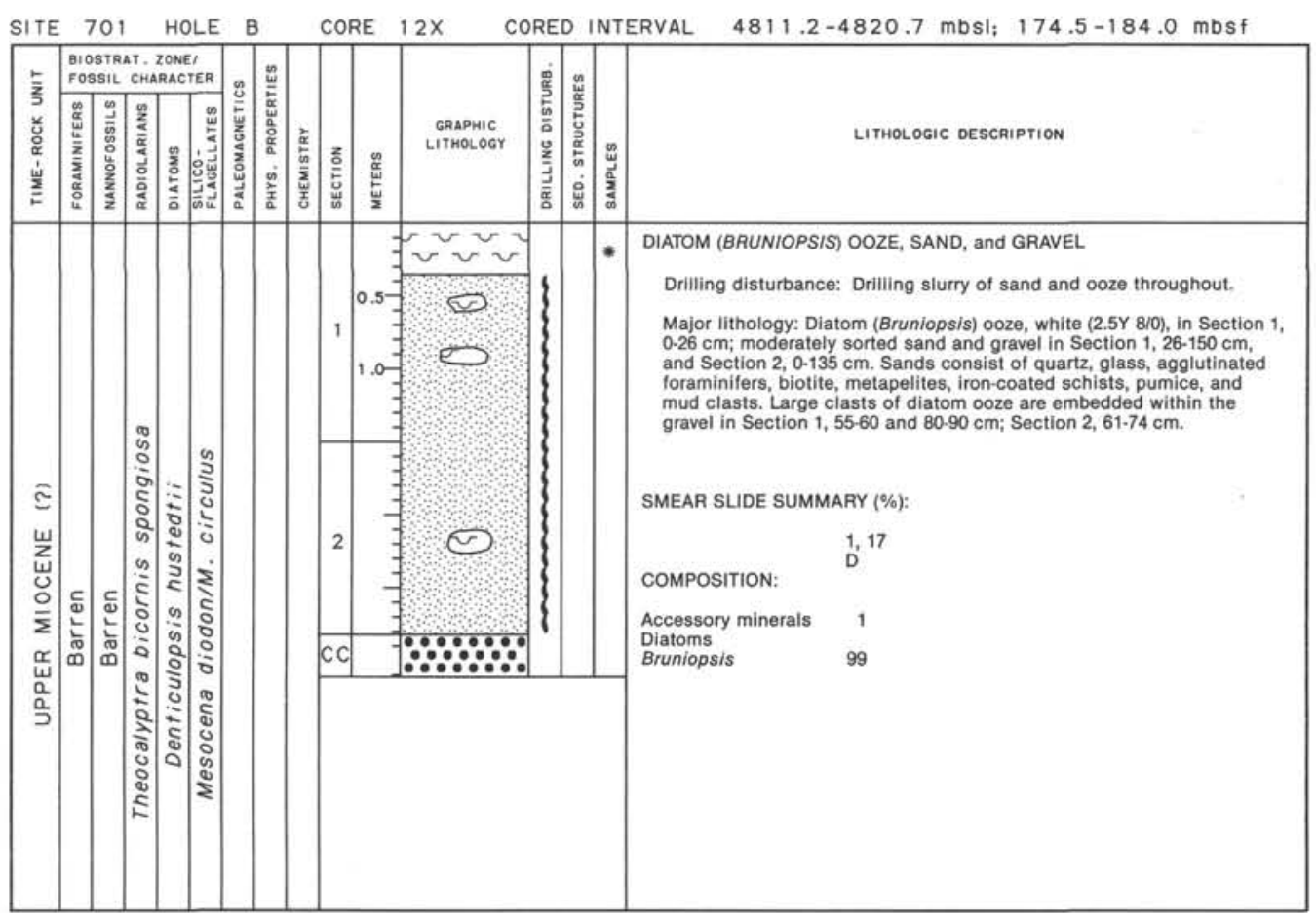

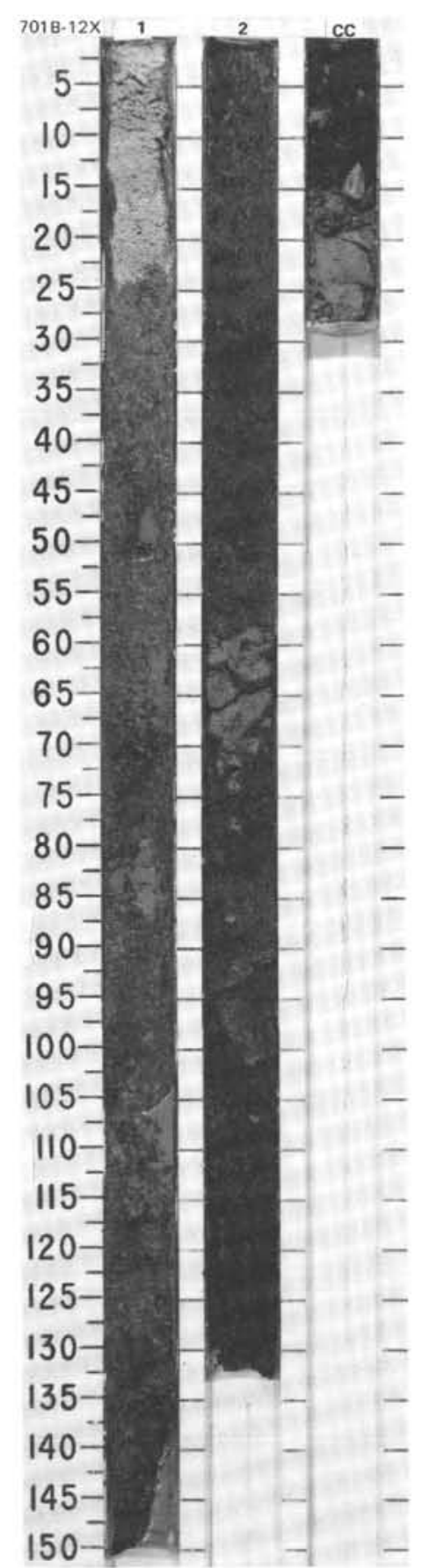




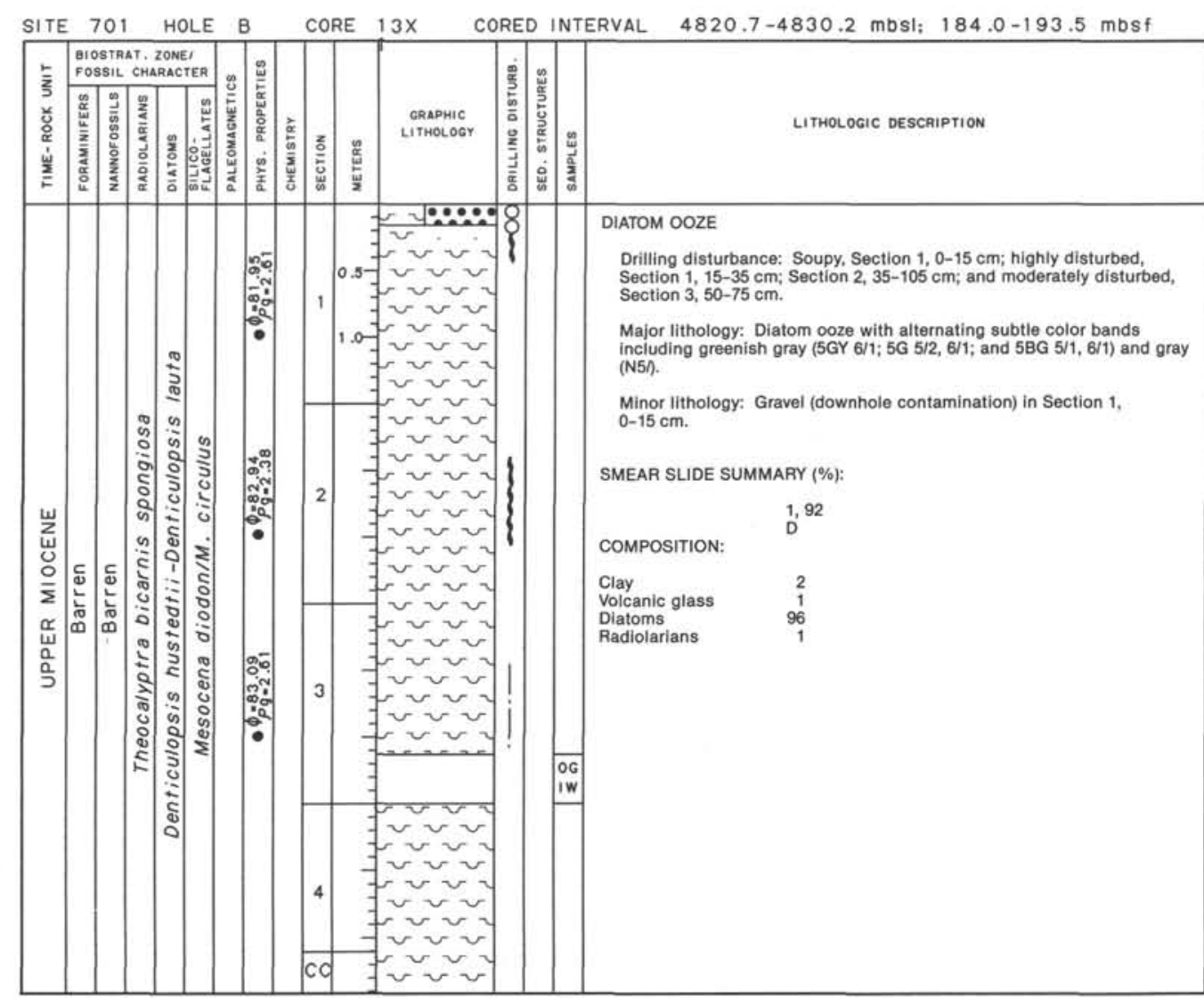

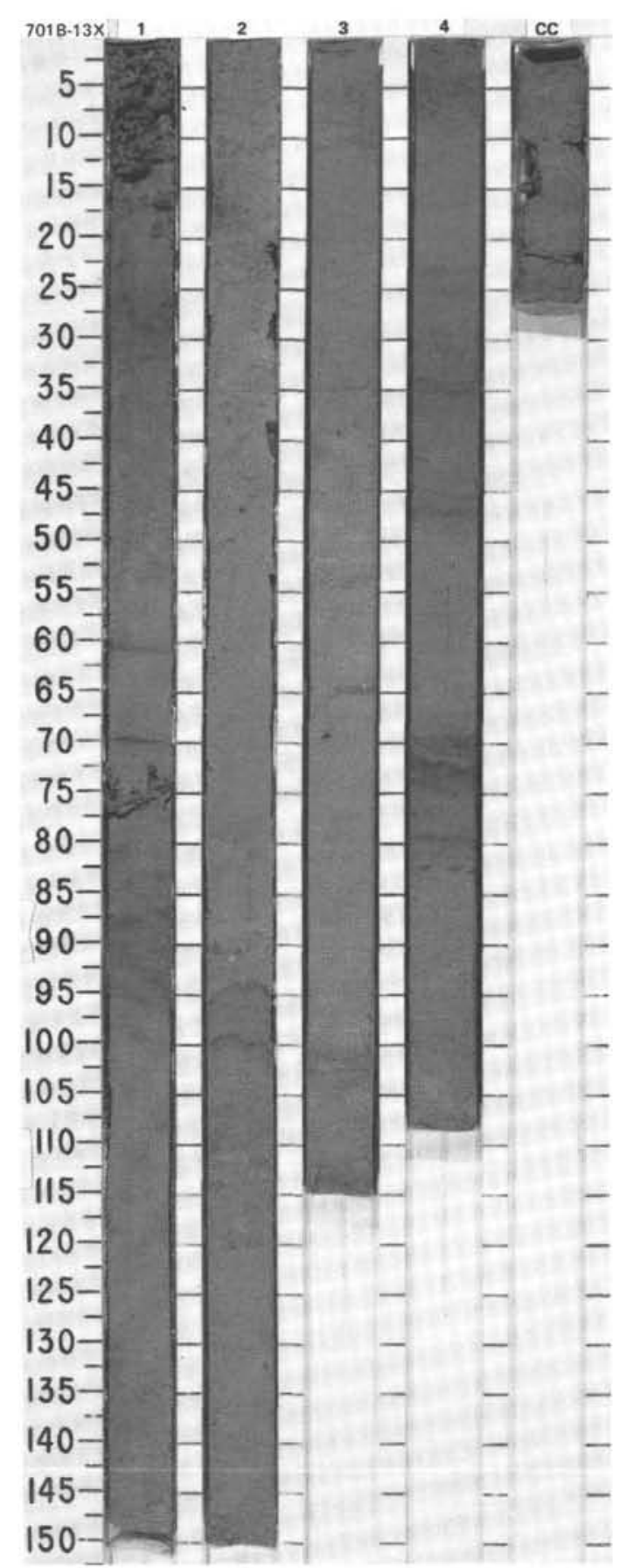



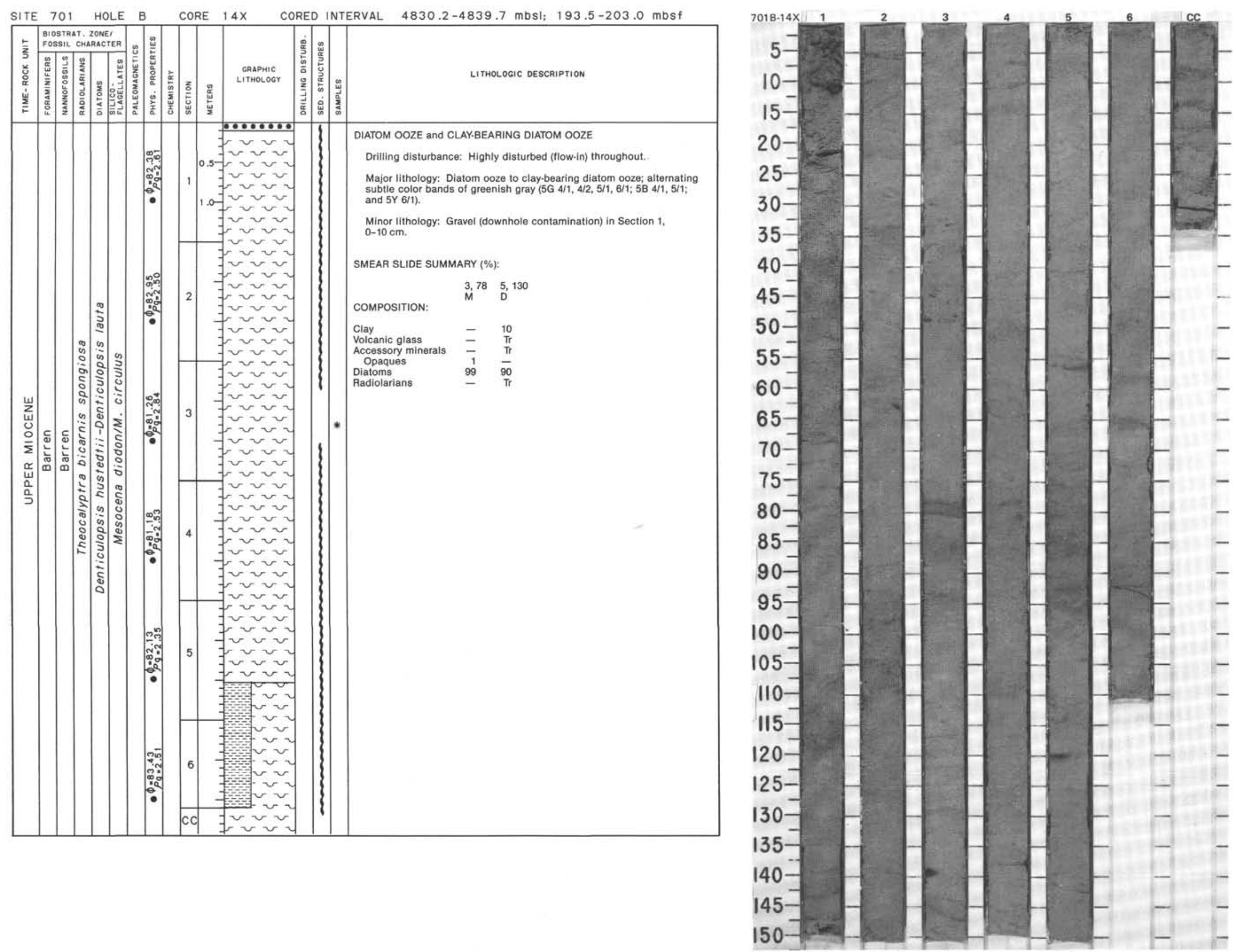


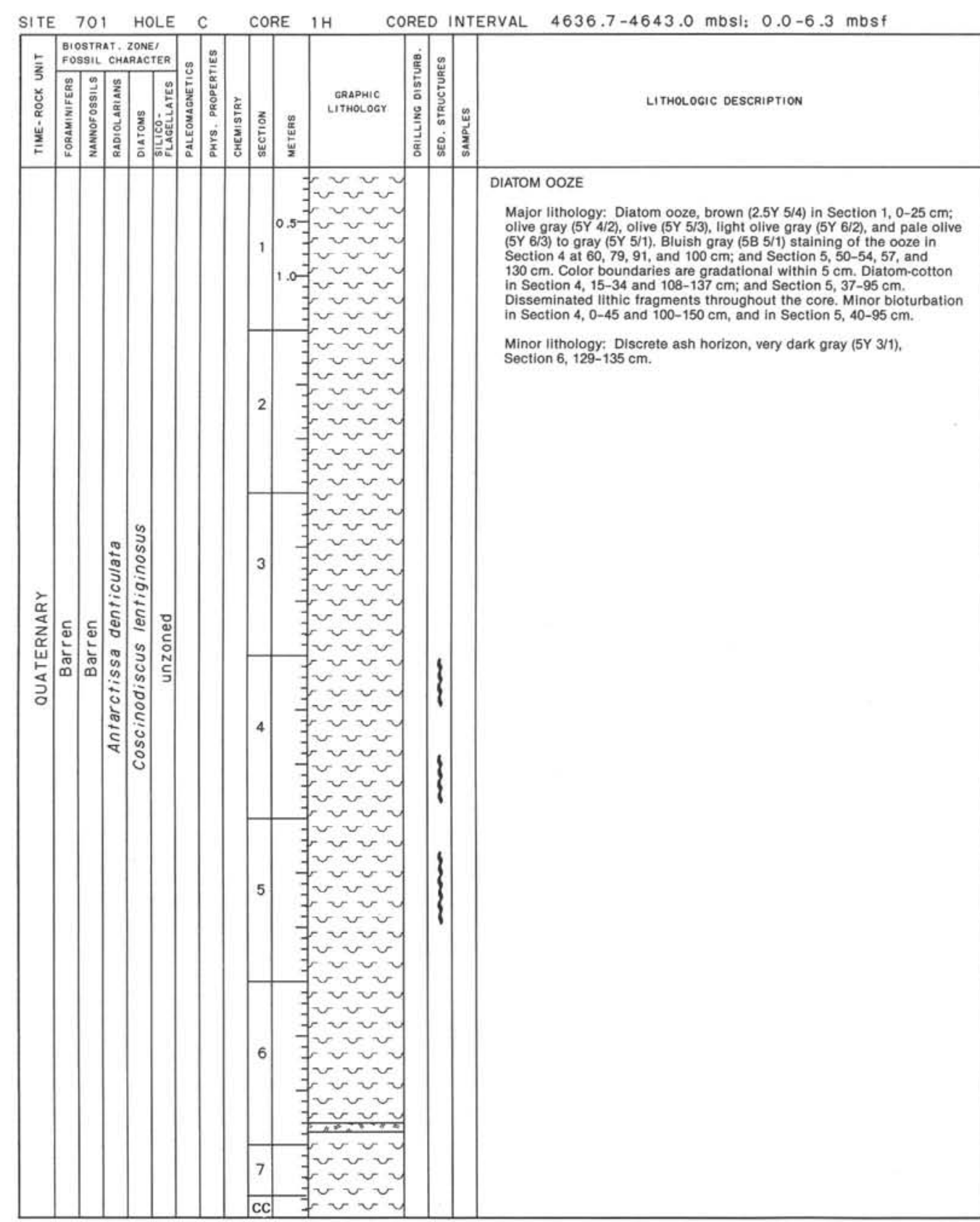

岕

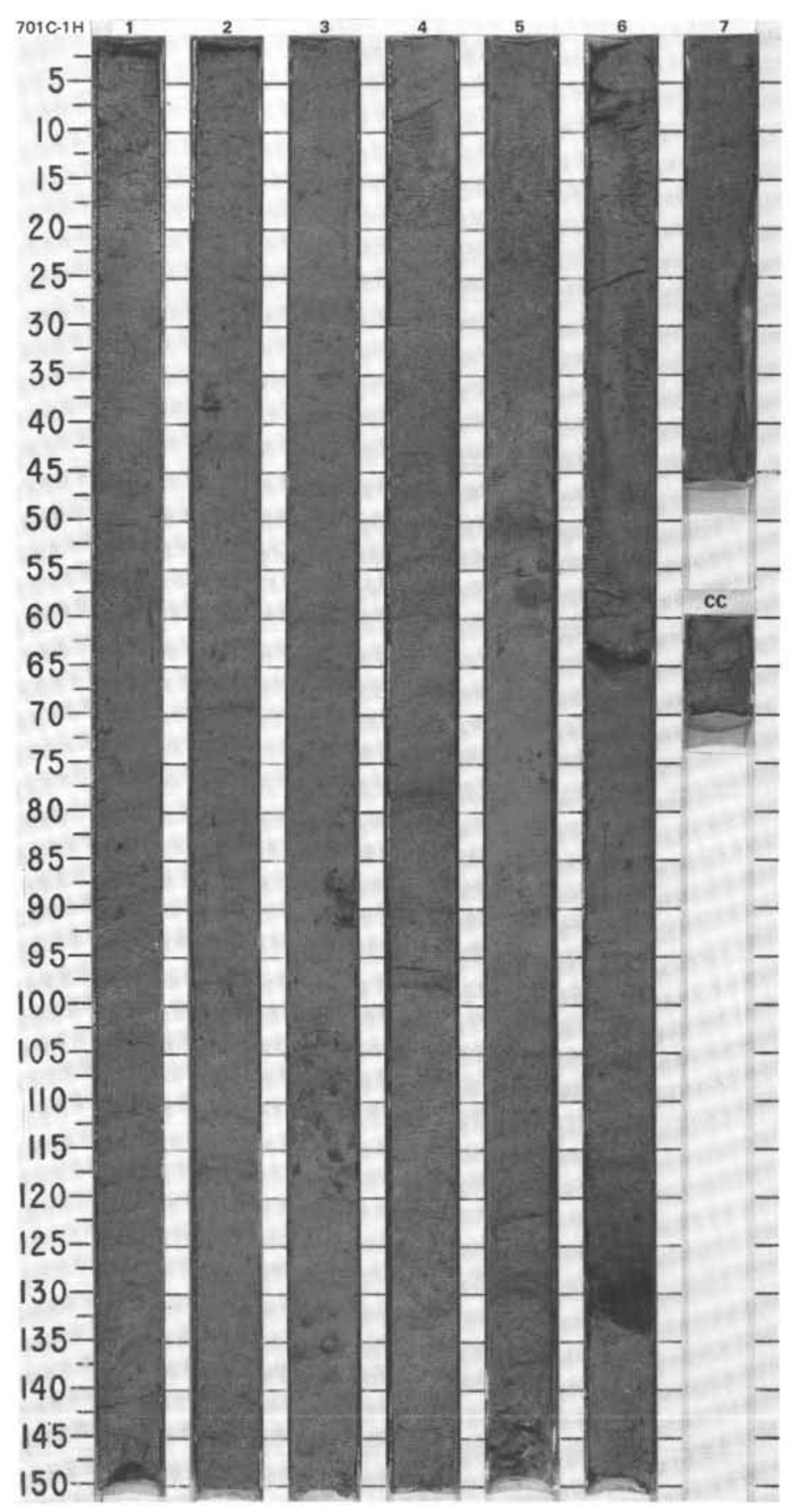



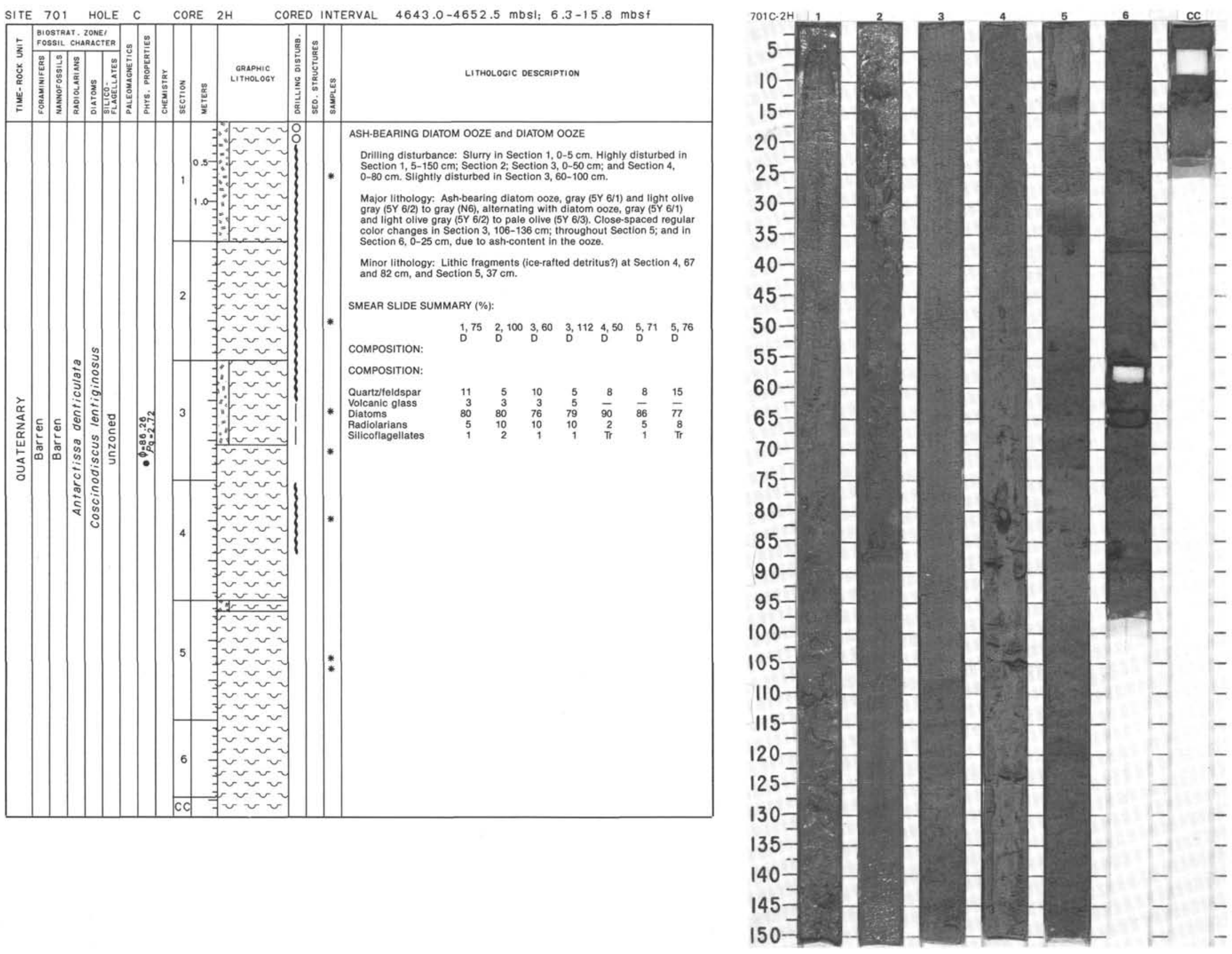


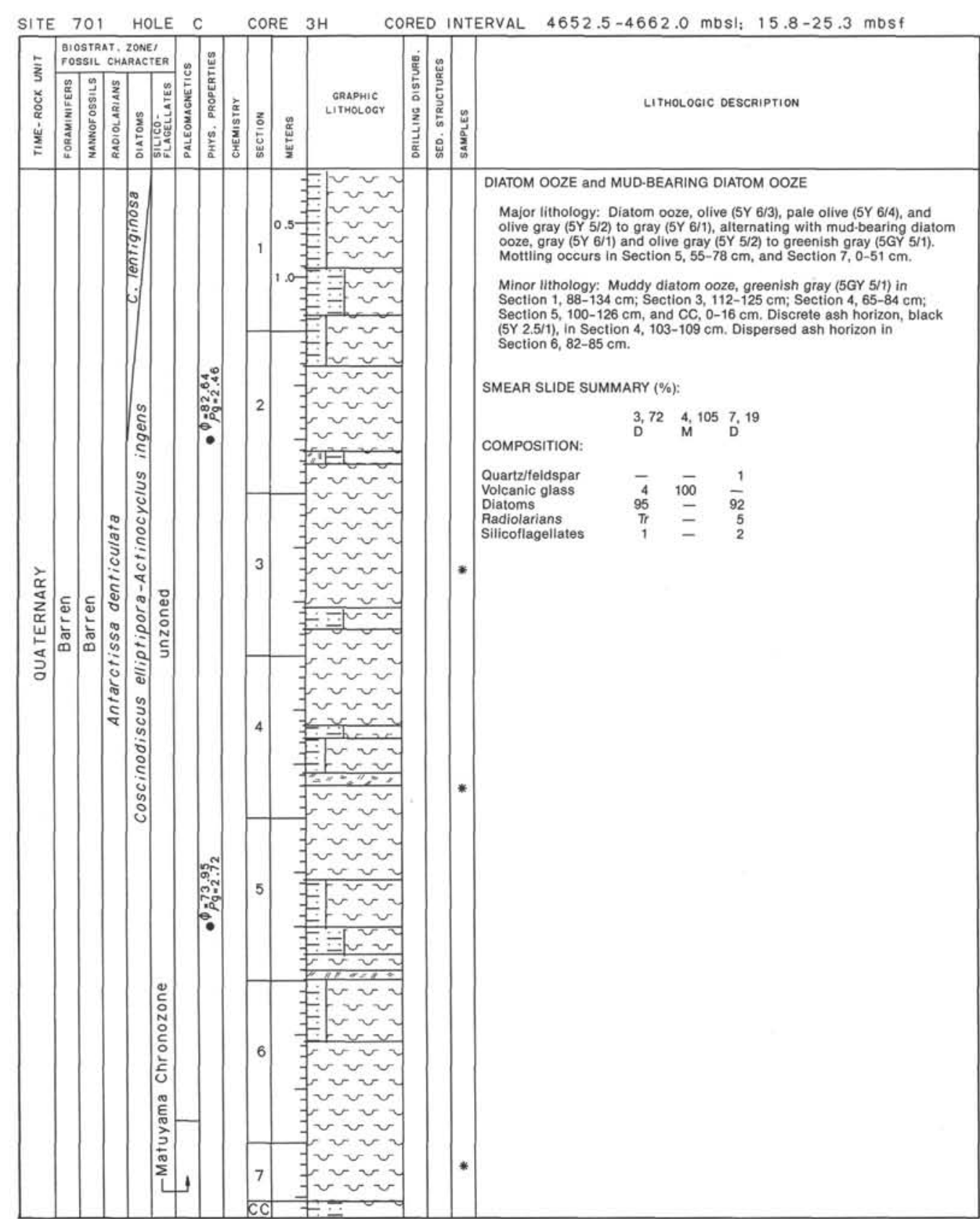

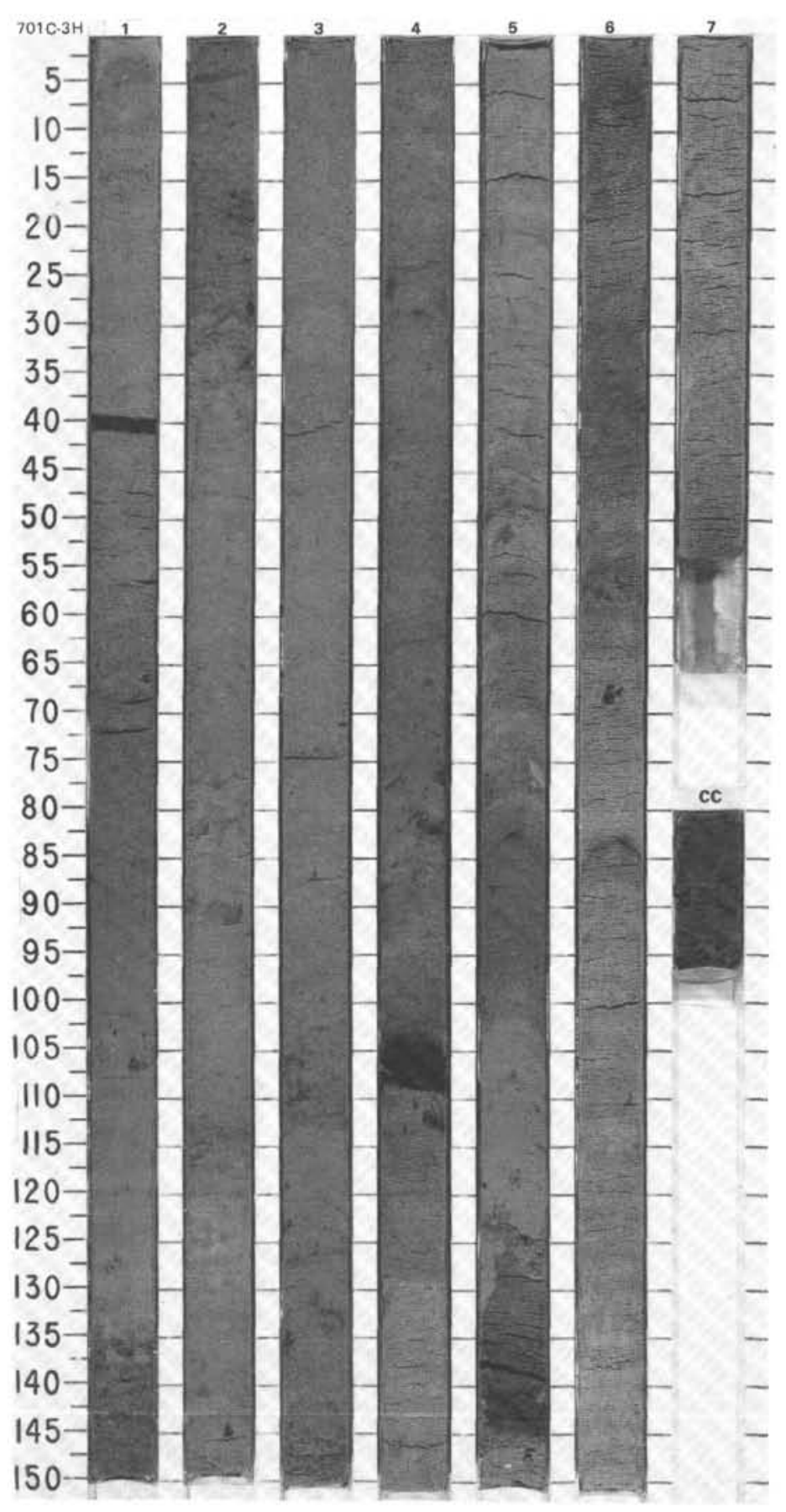

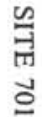



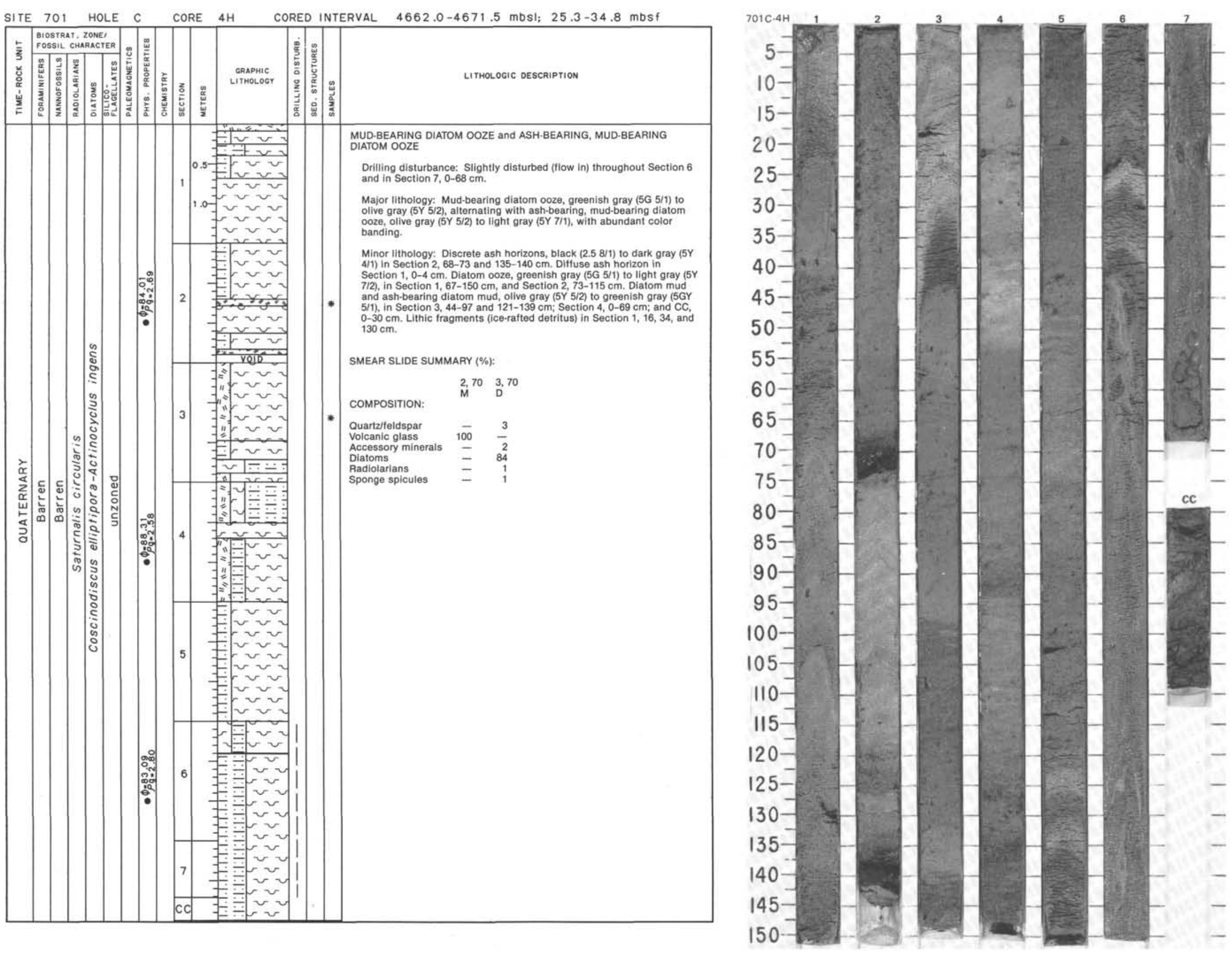

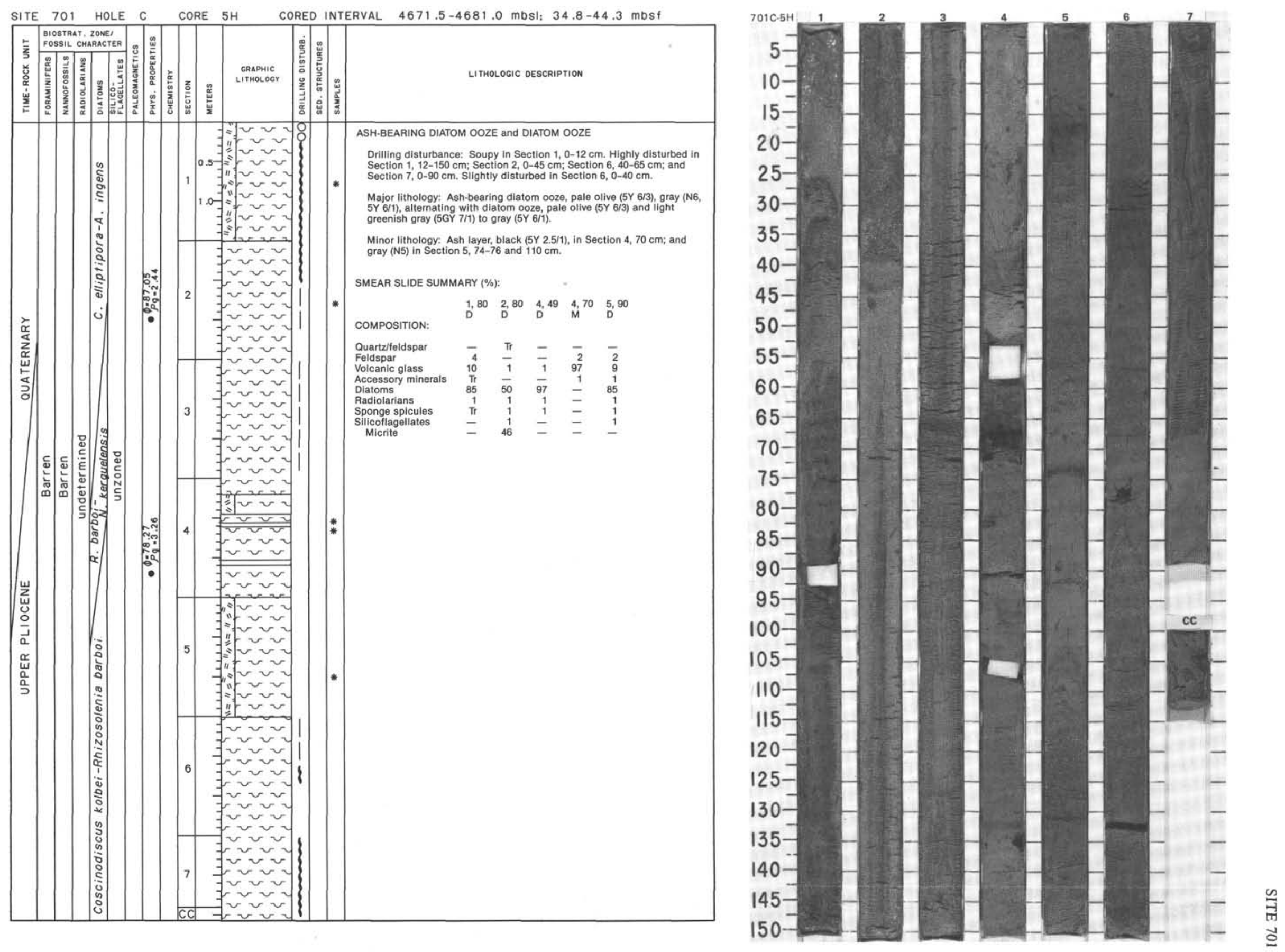

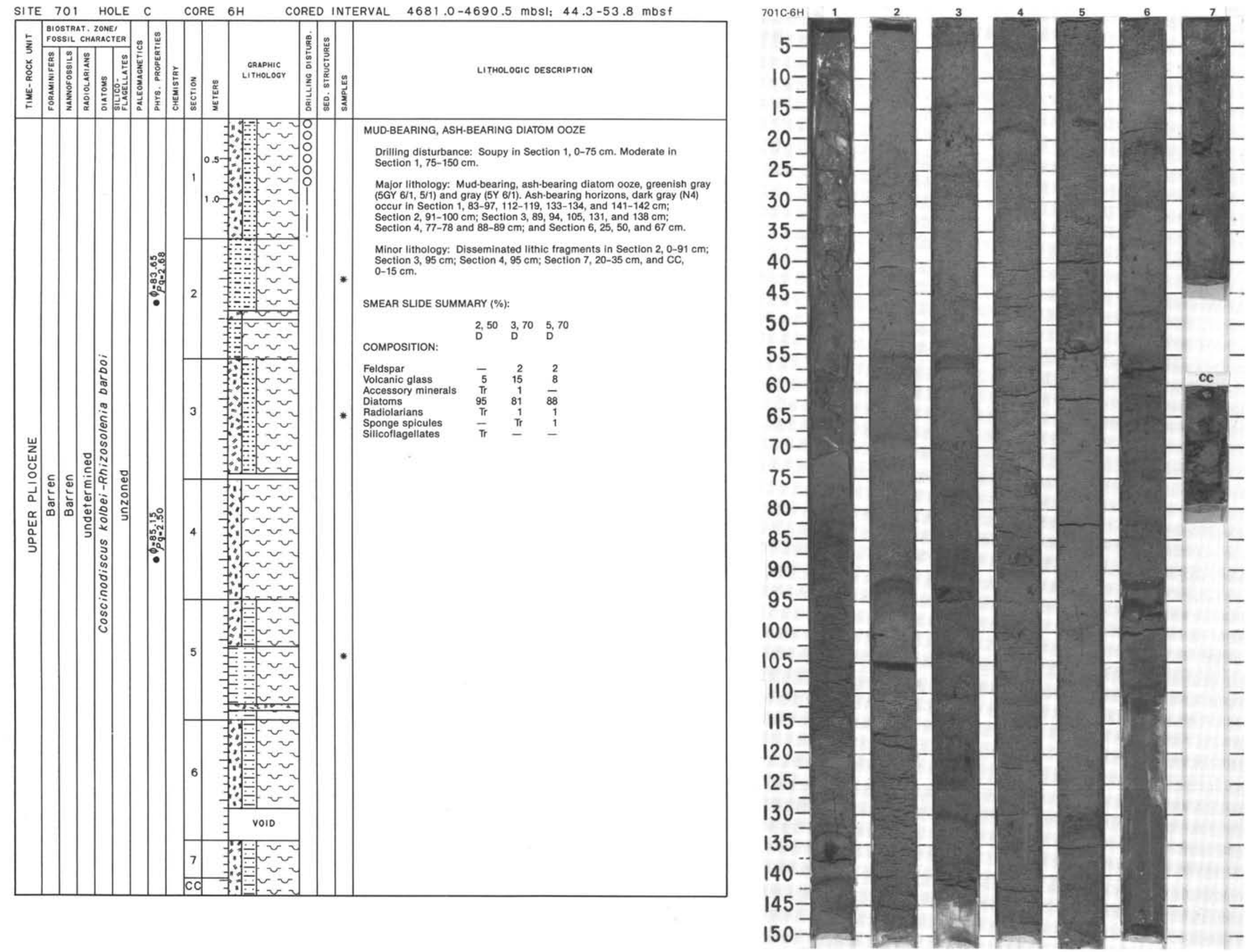

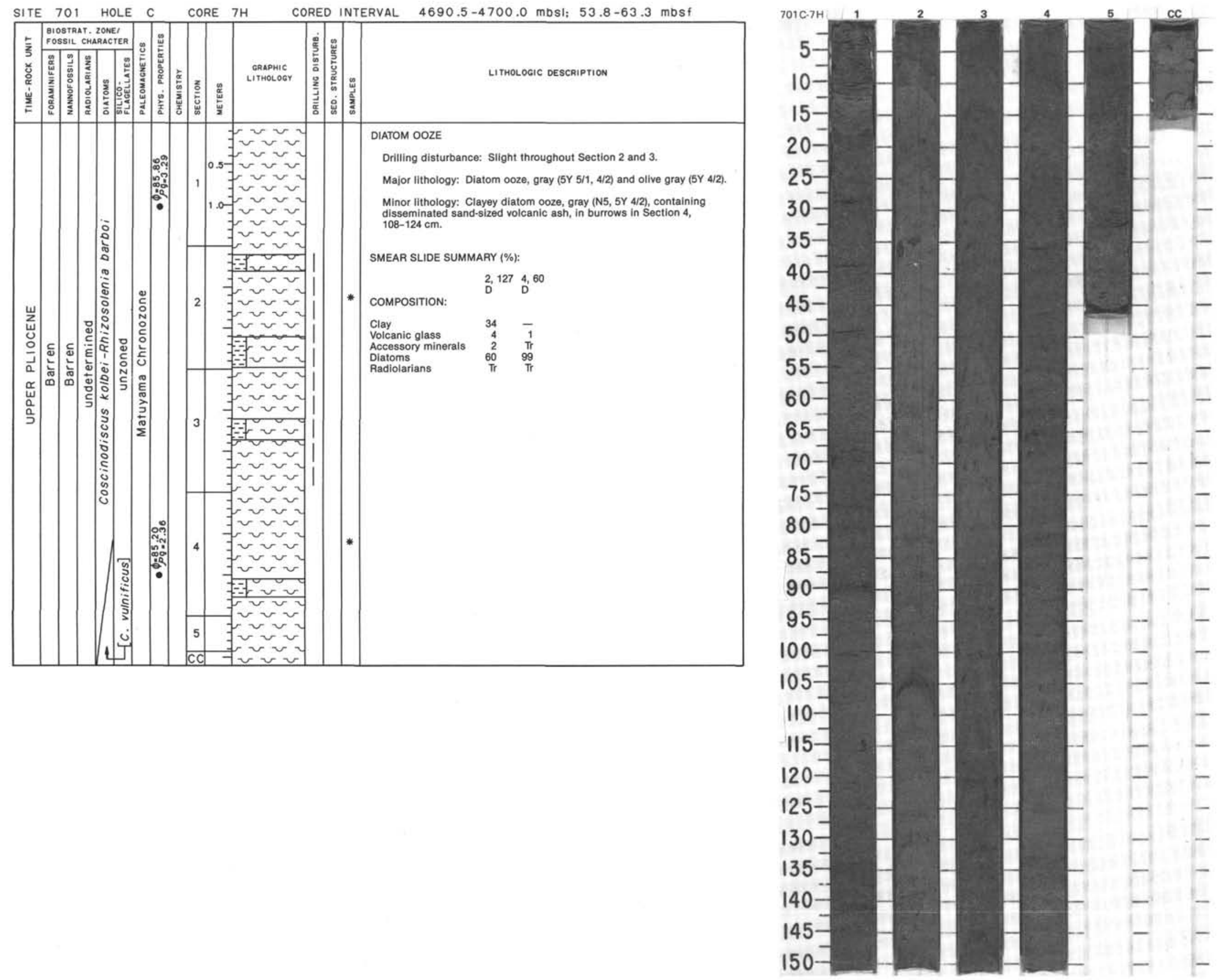

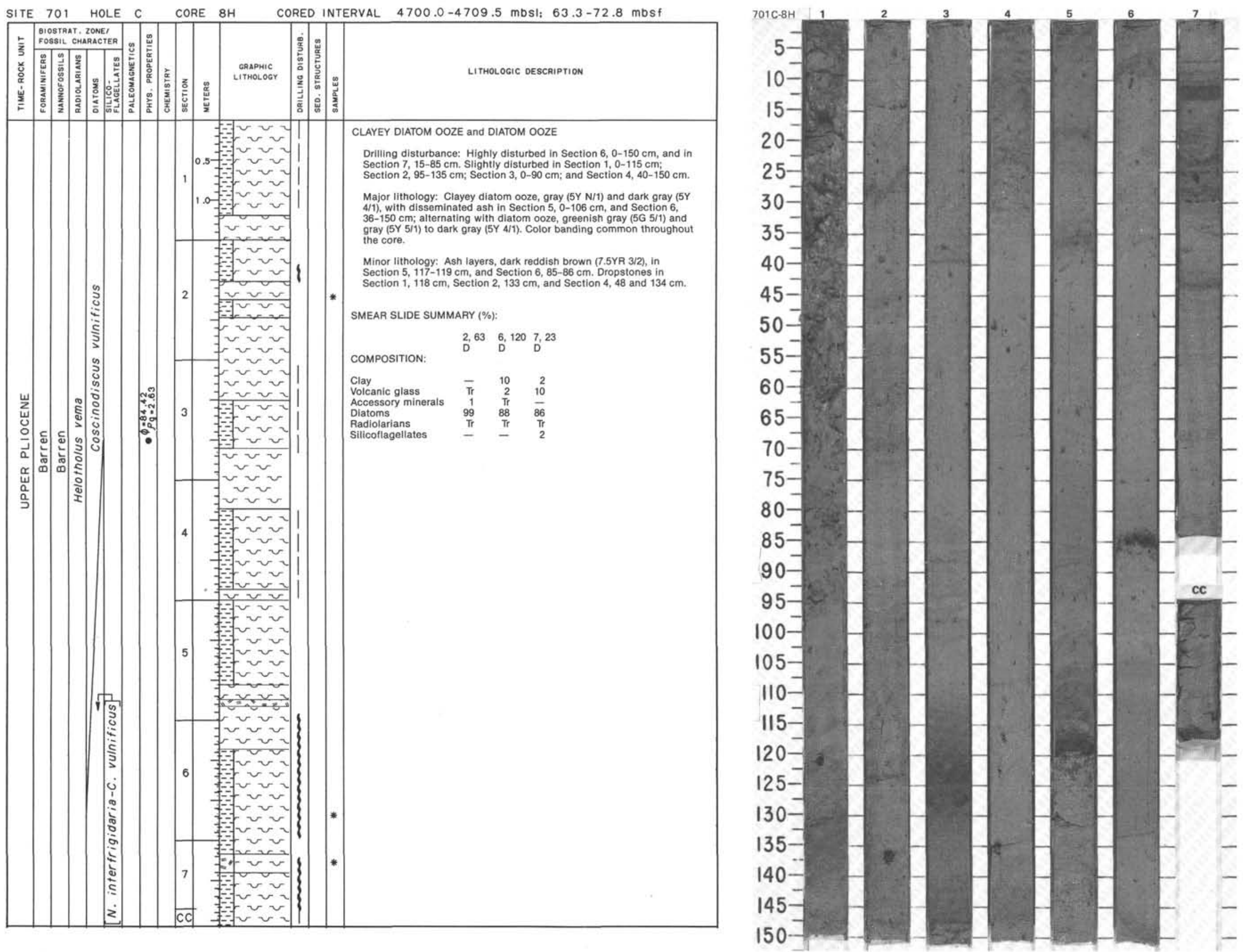

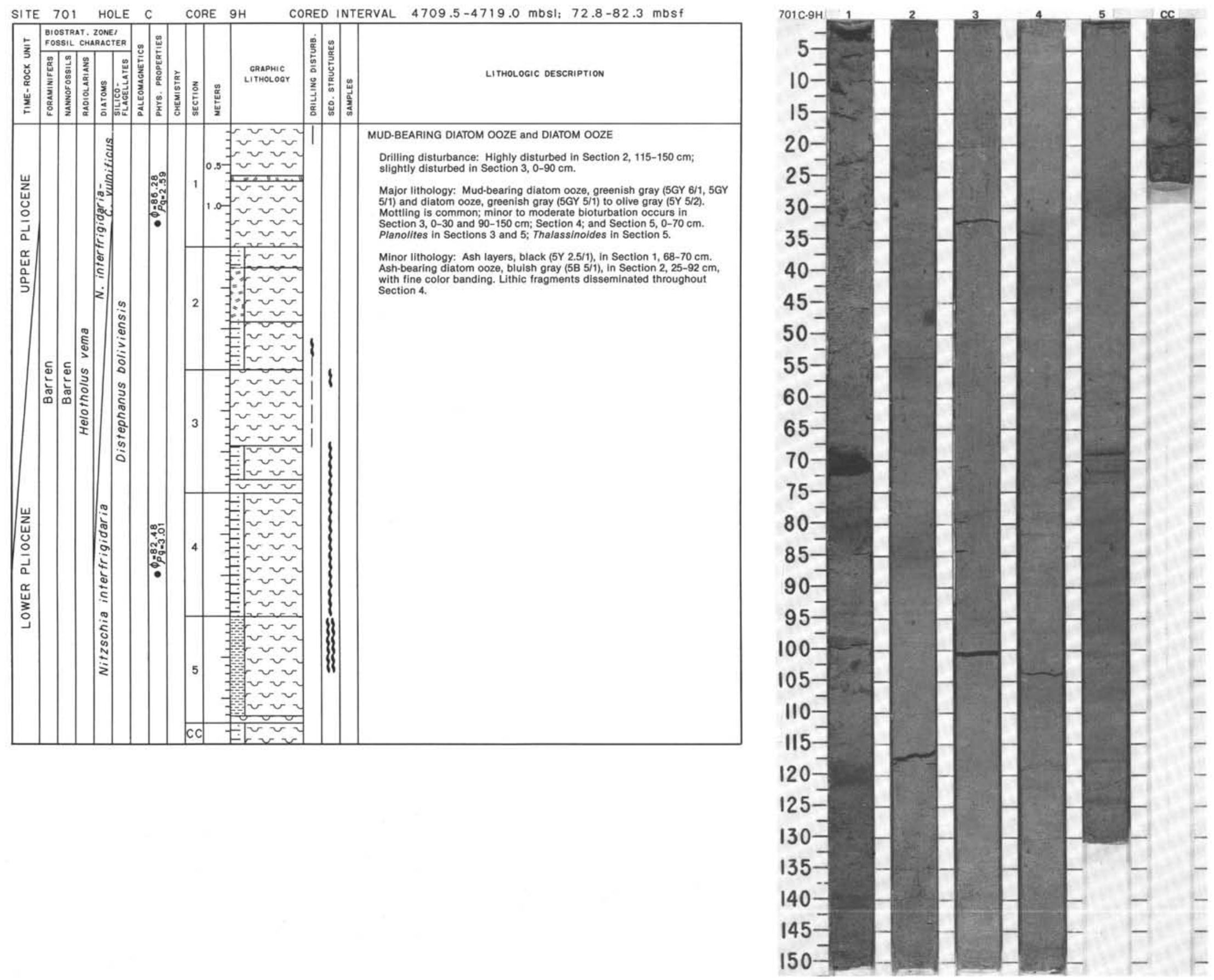

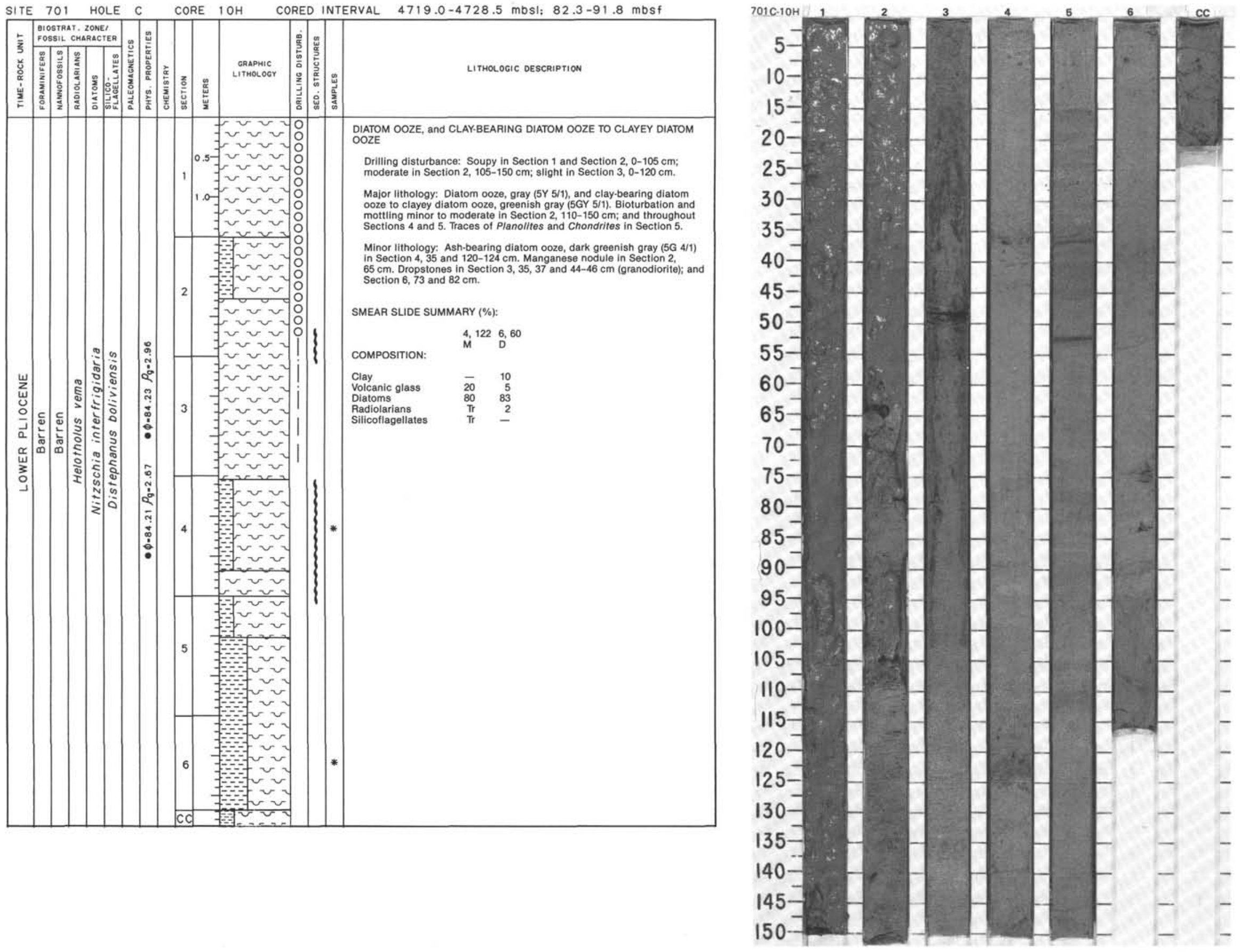

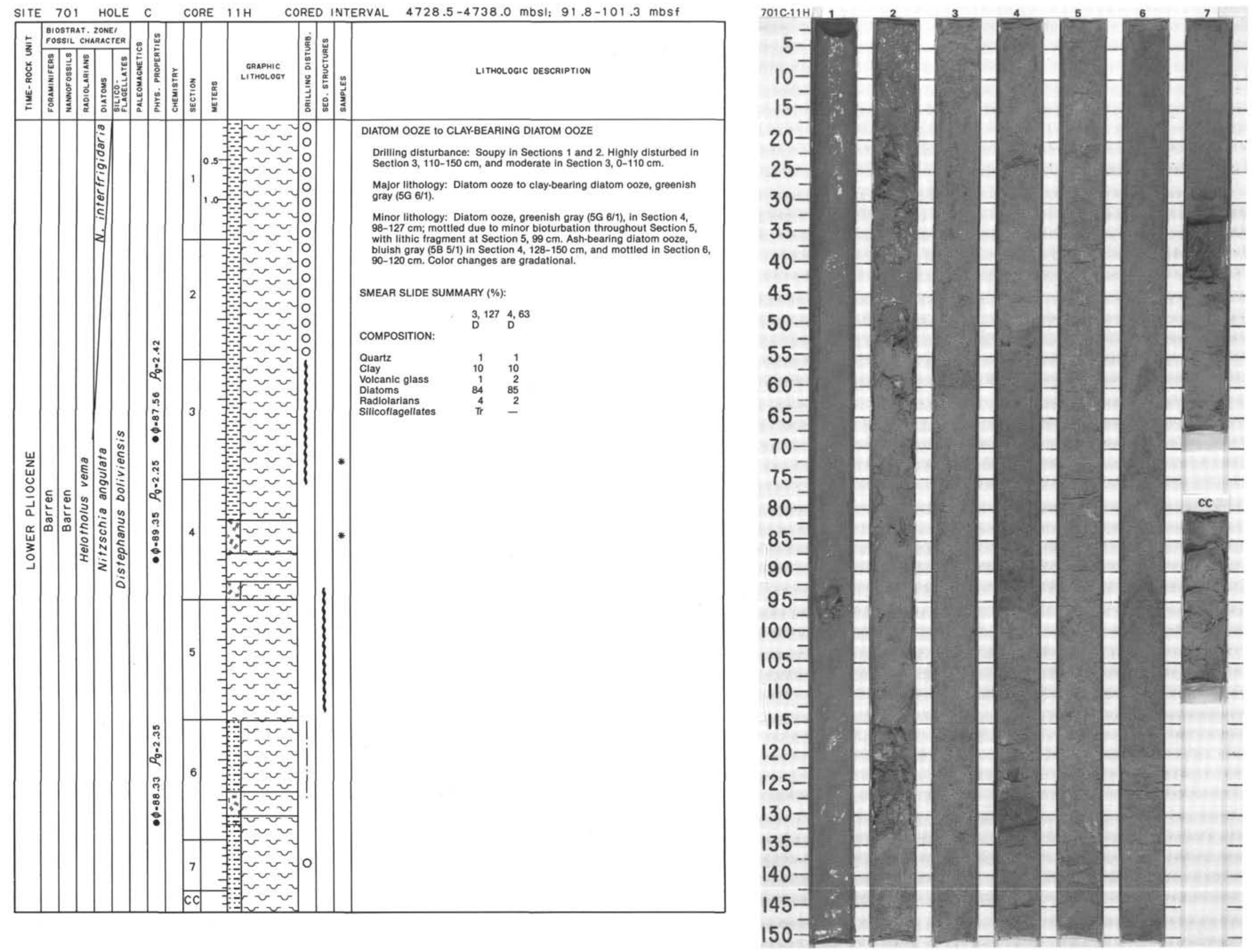

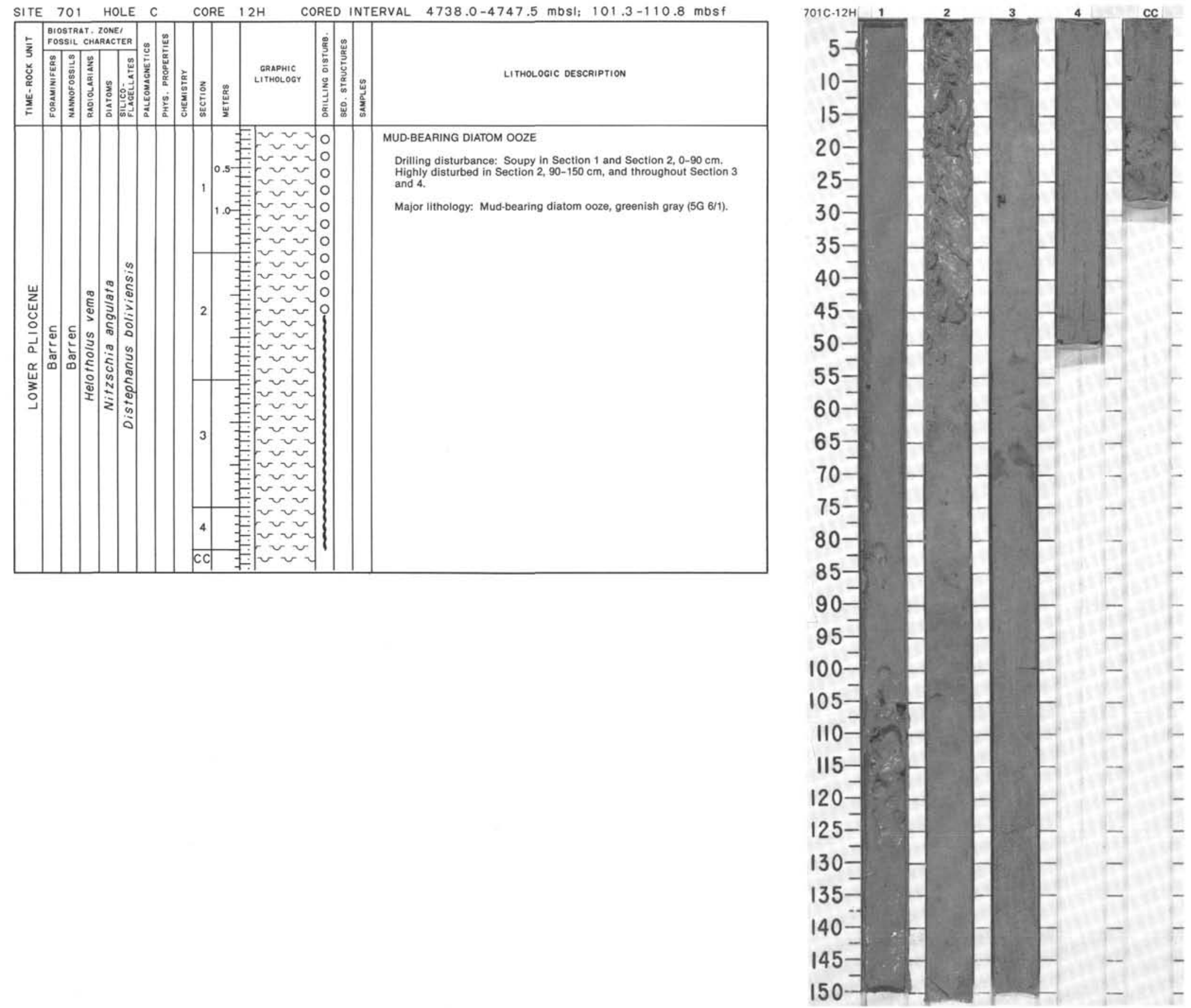

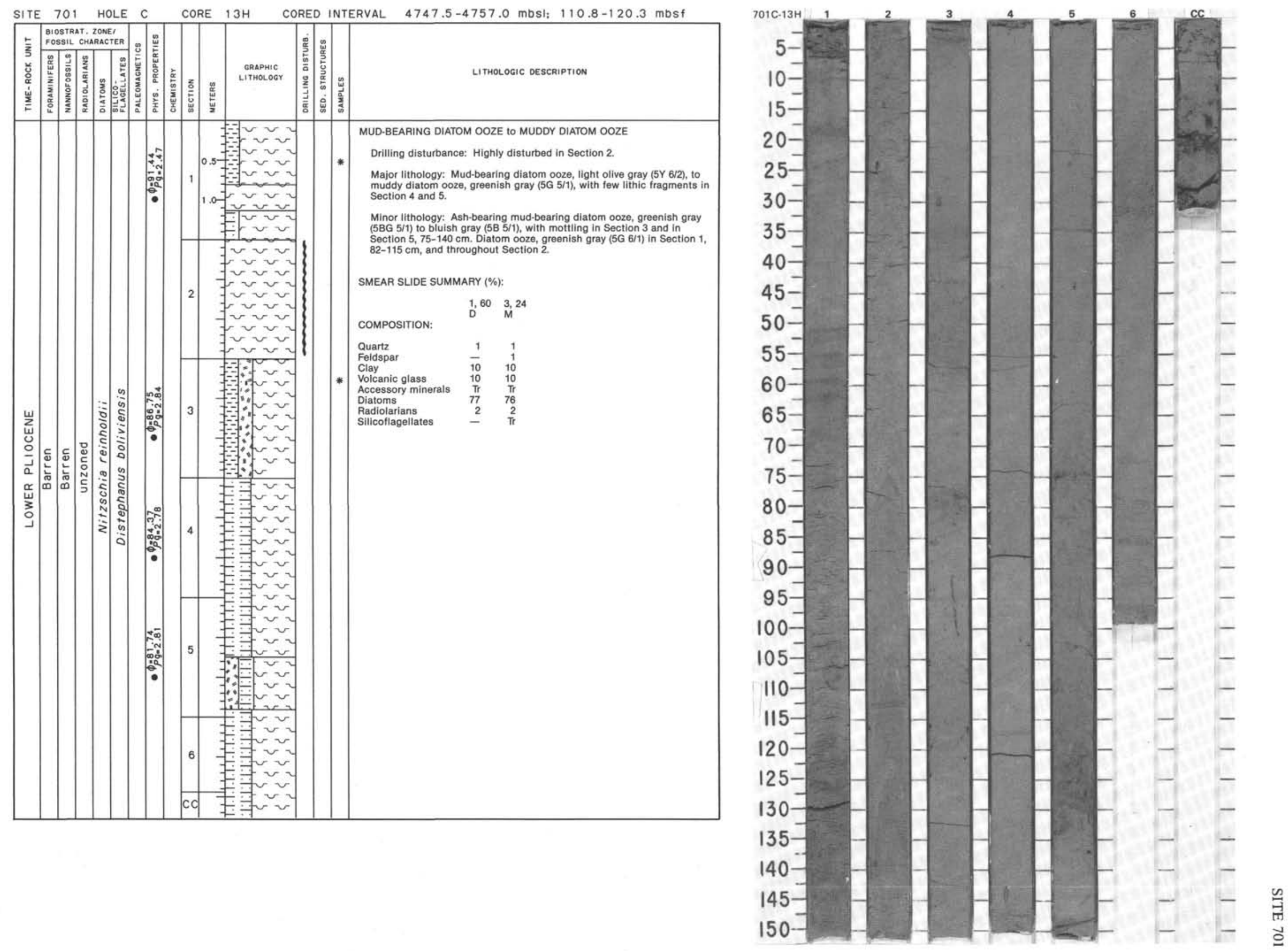

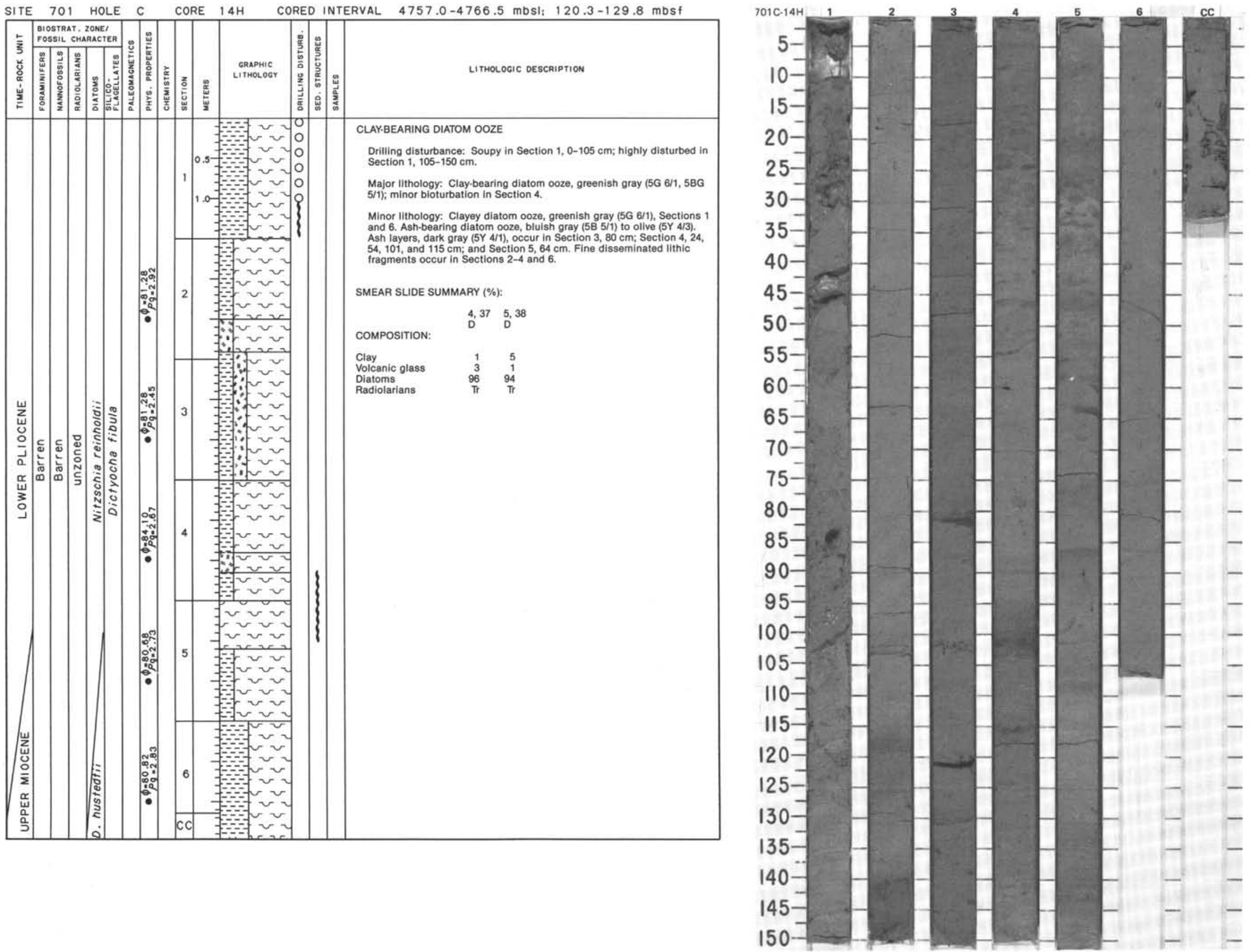

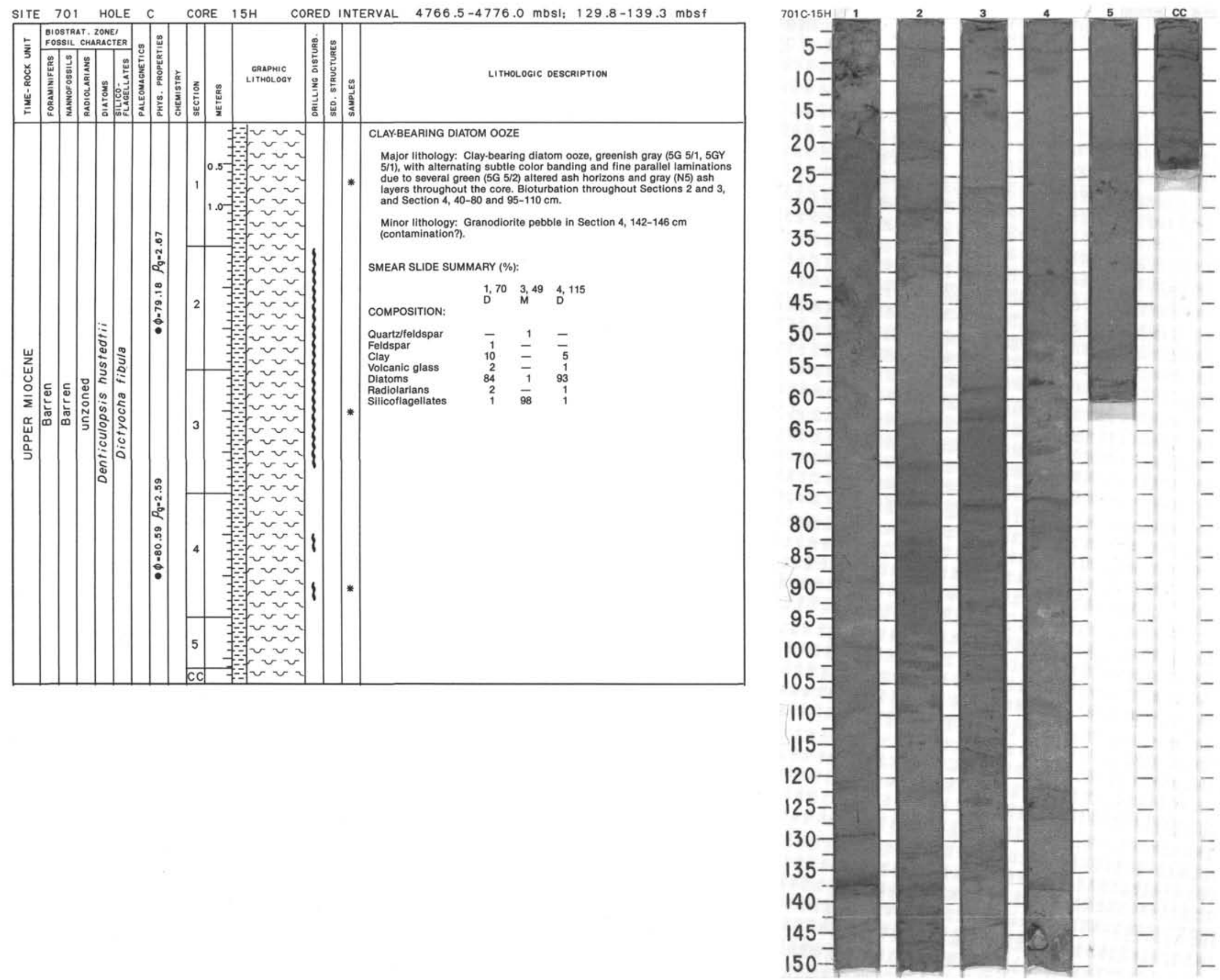

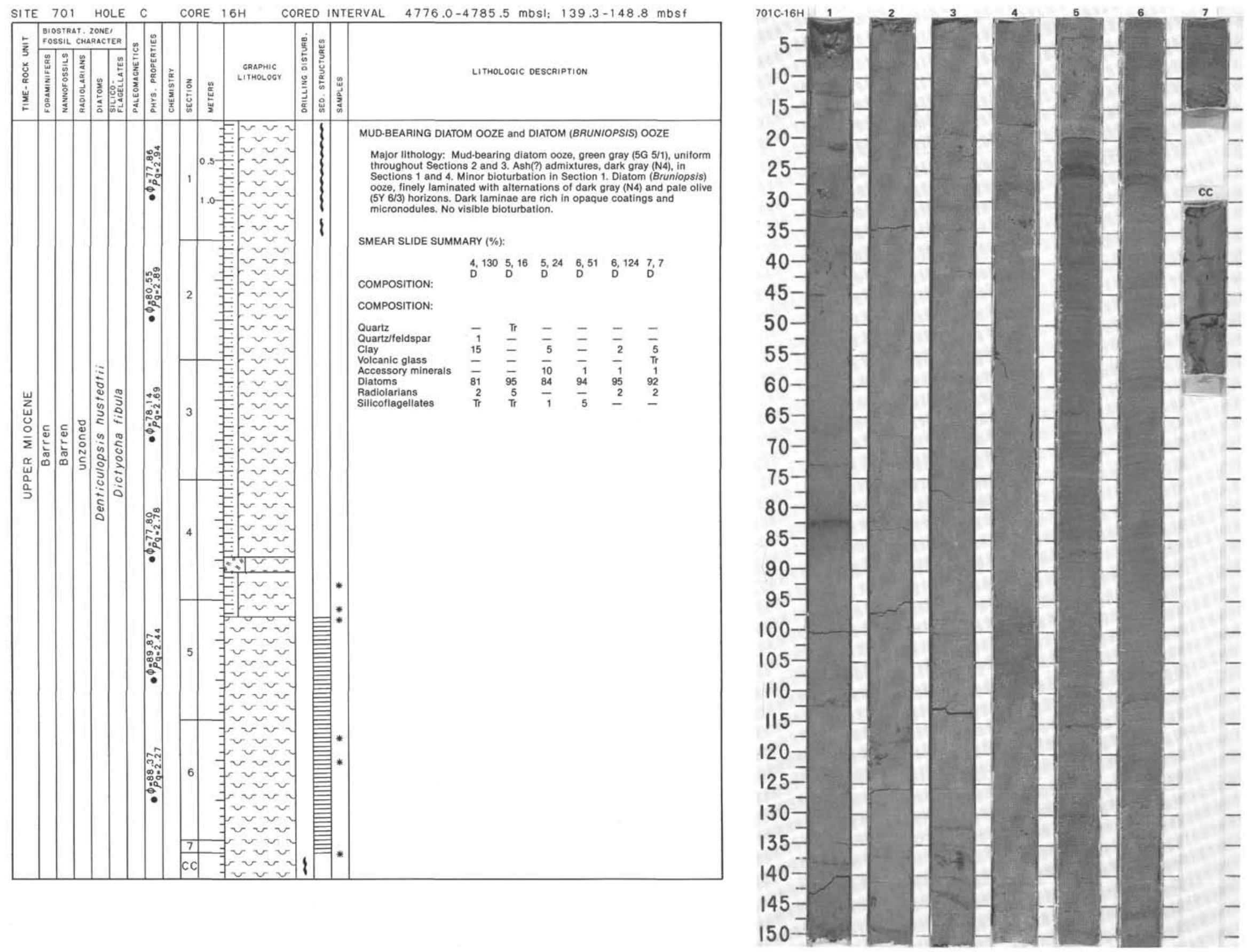


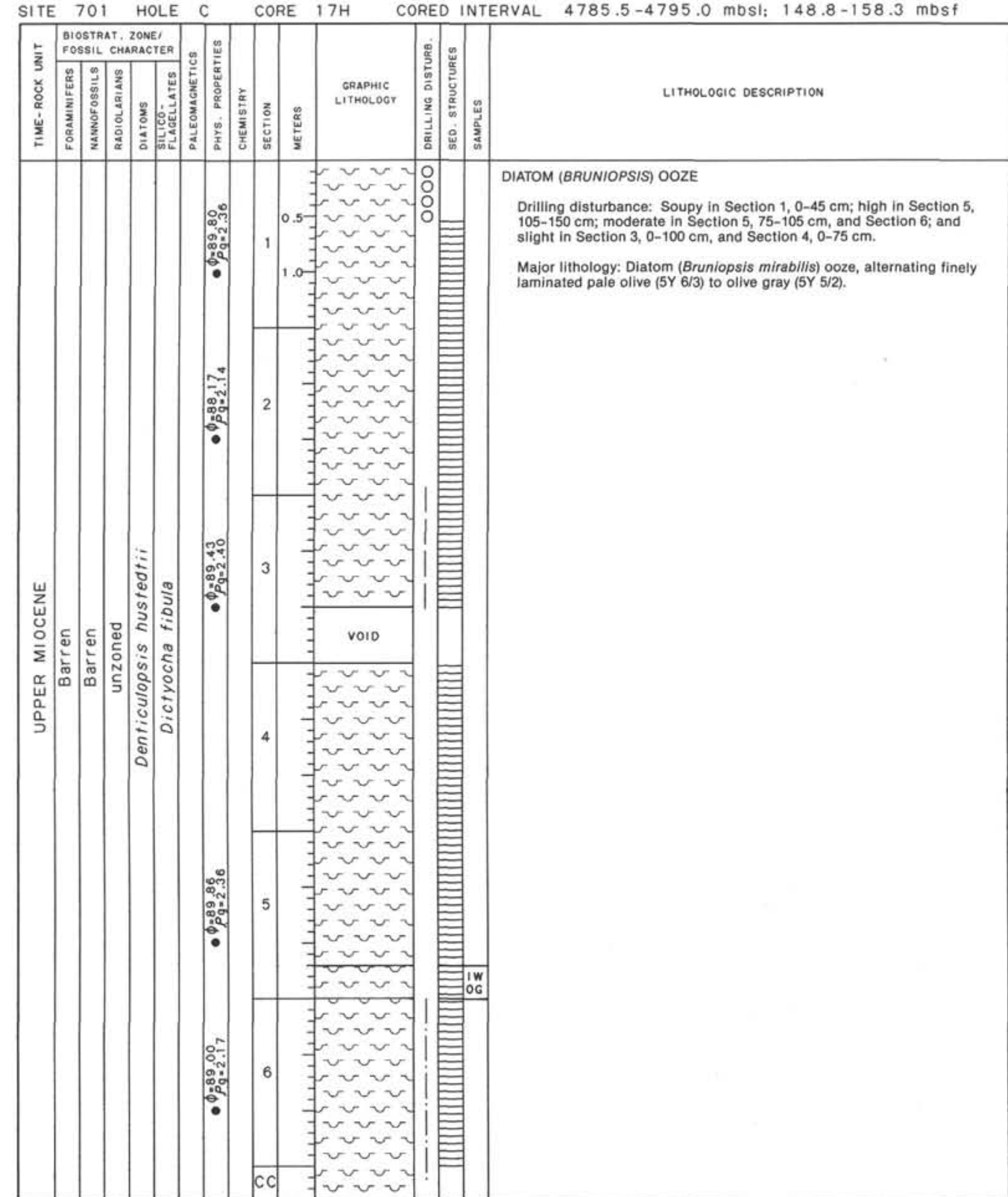

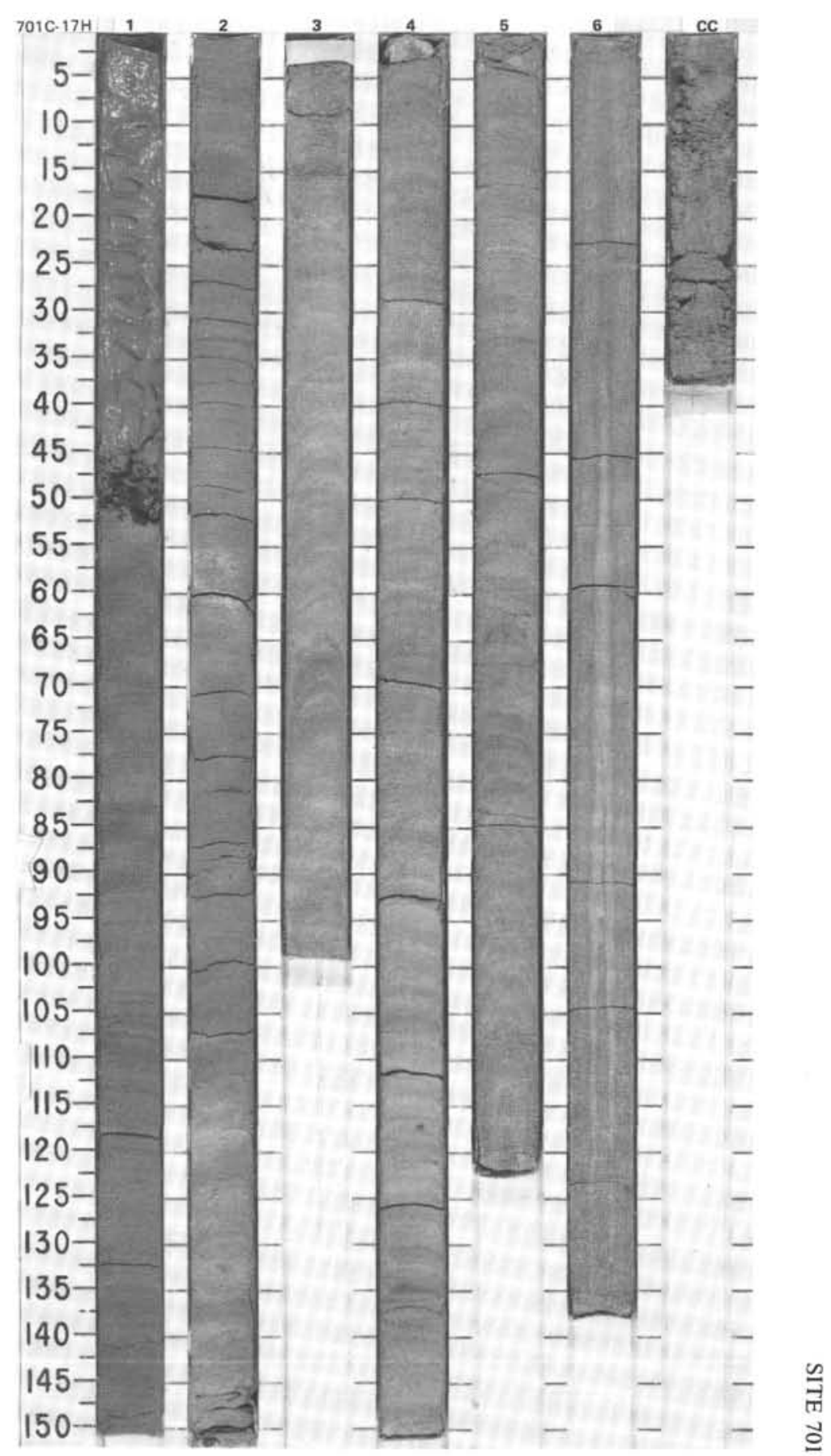



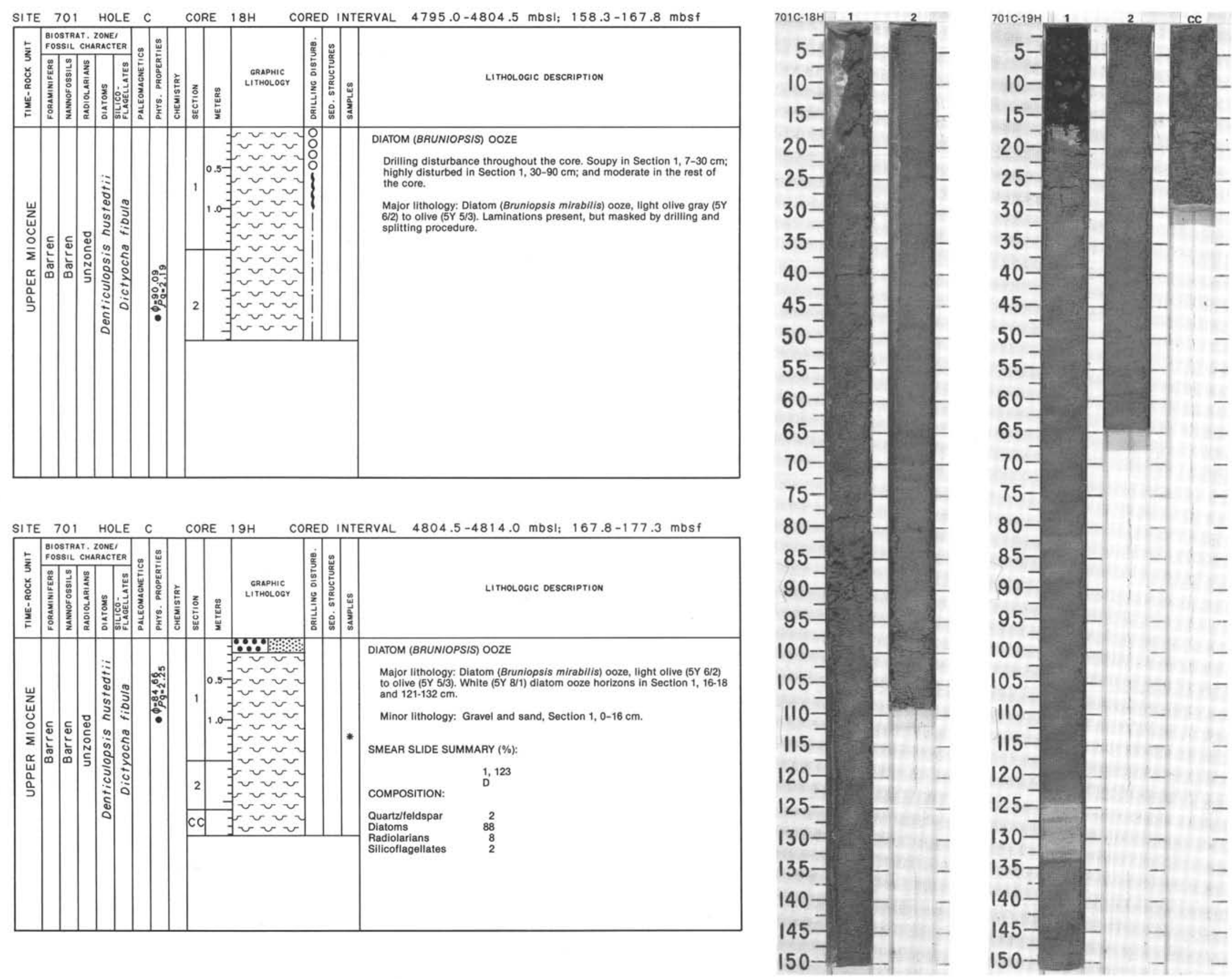

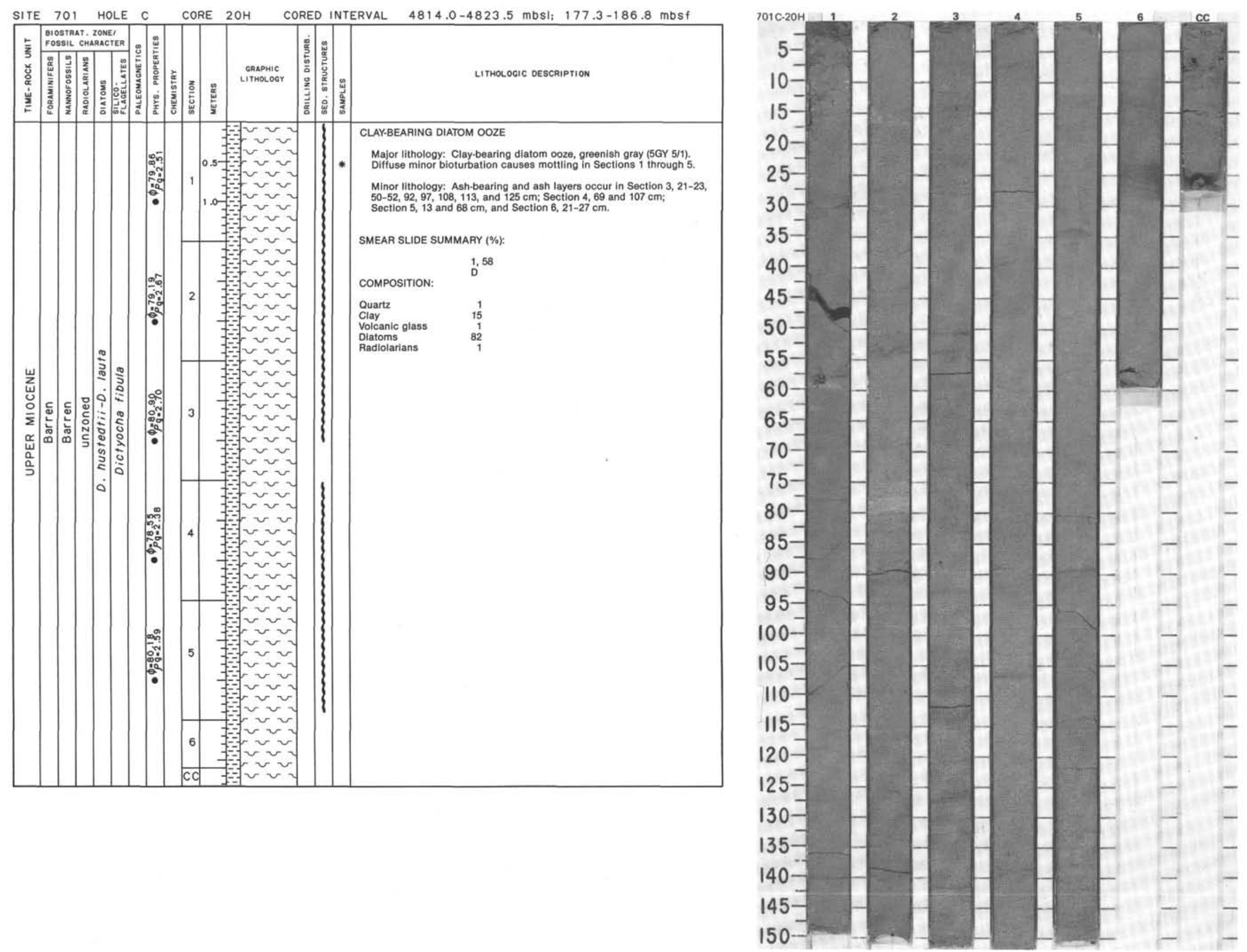


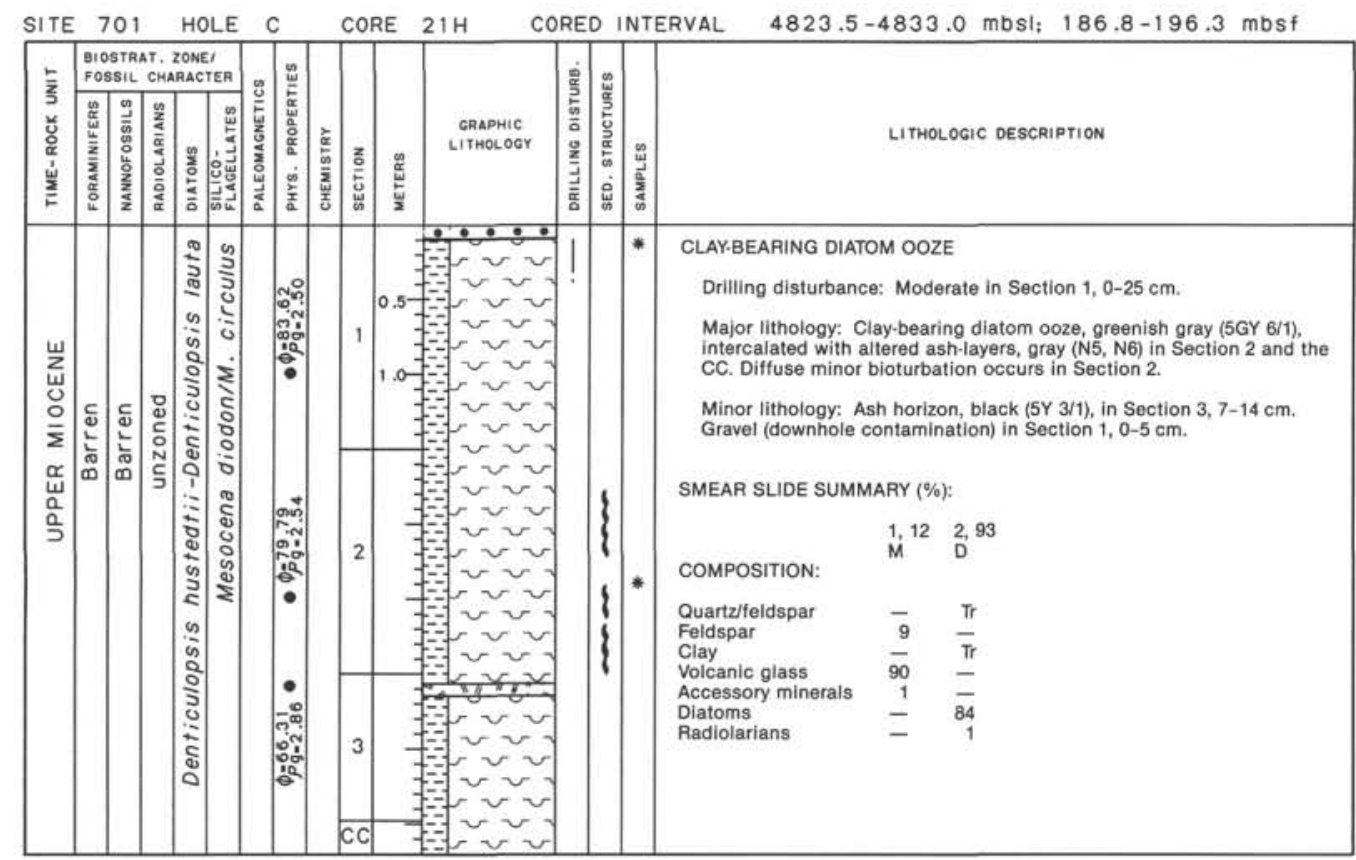

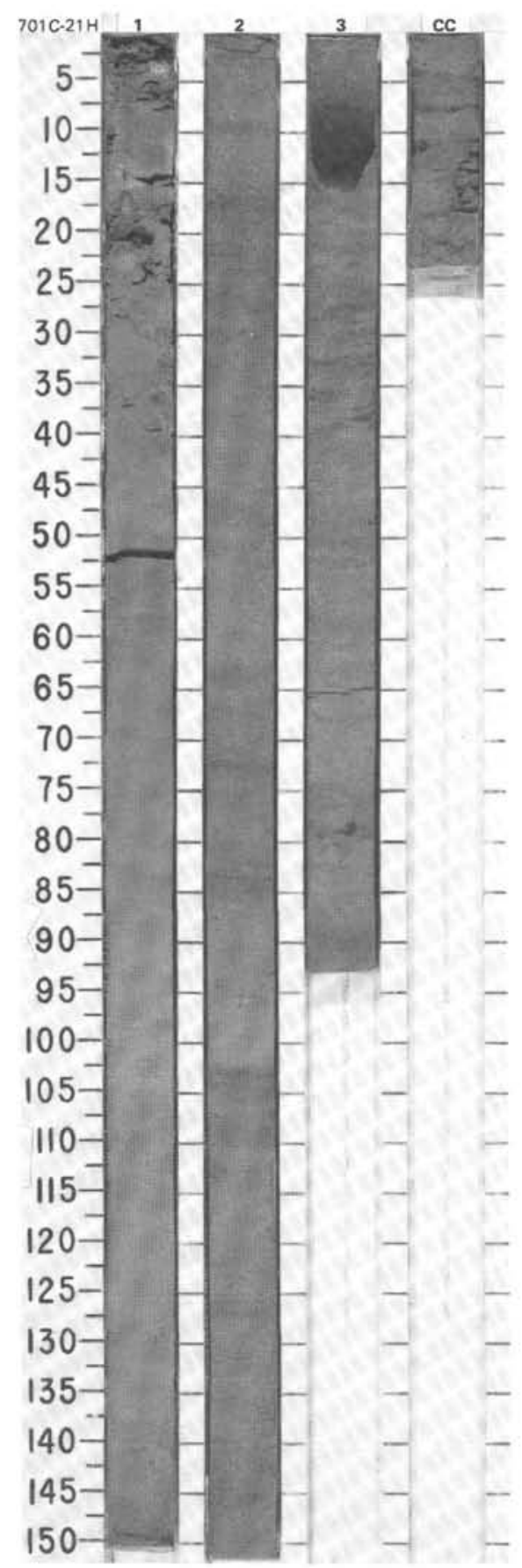



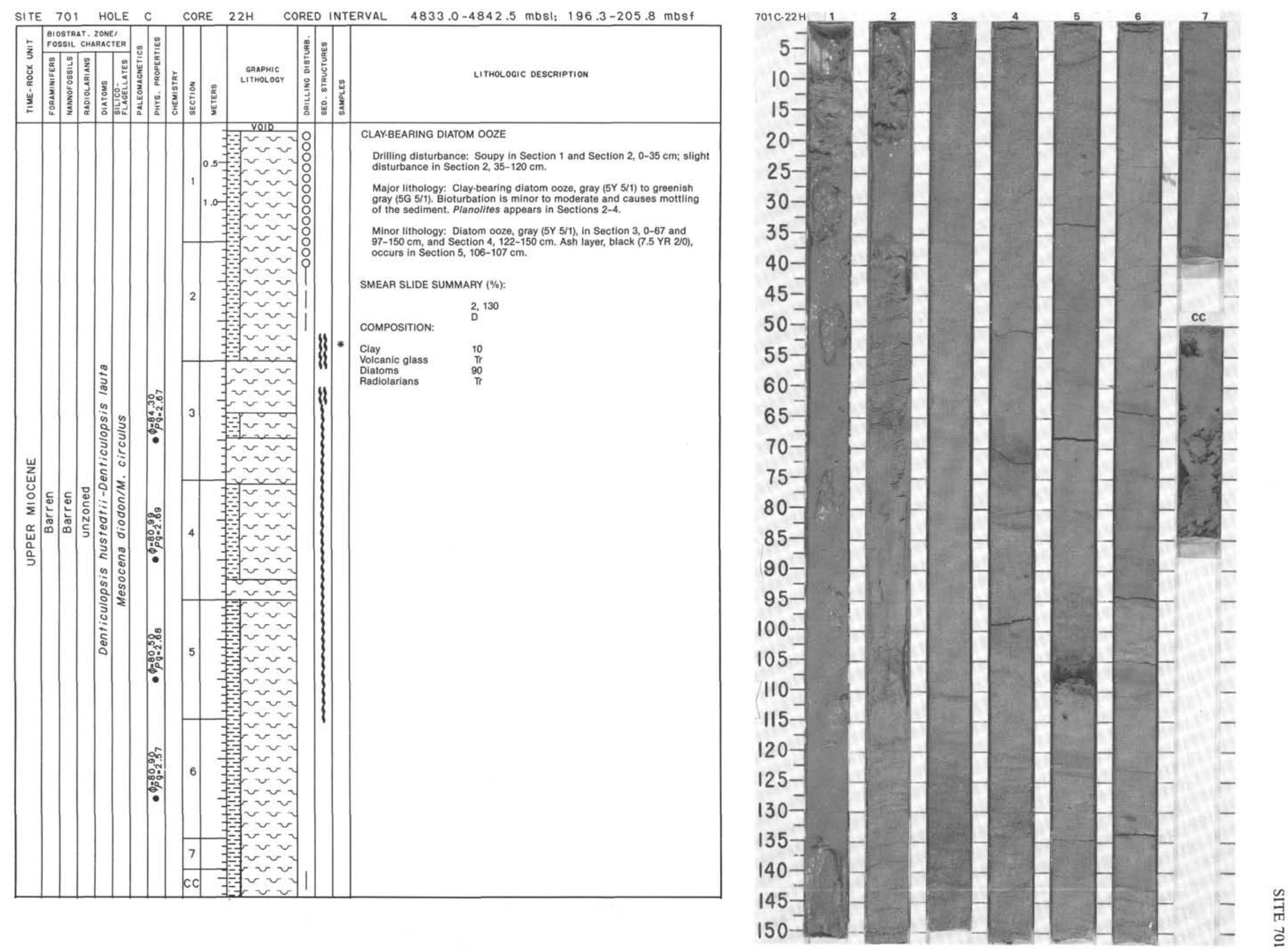

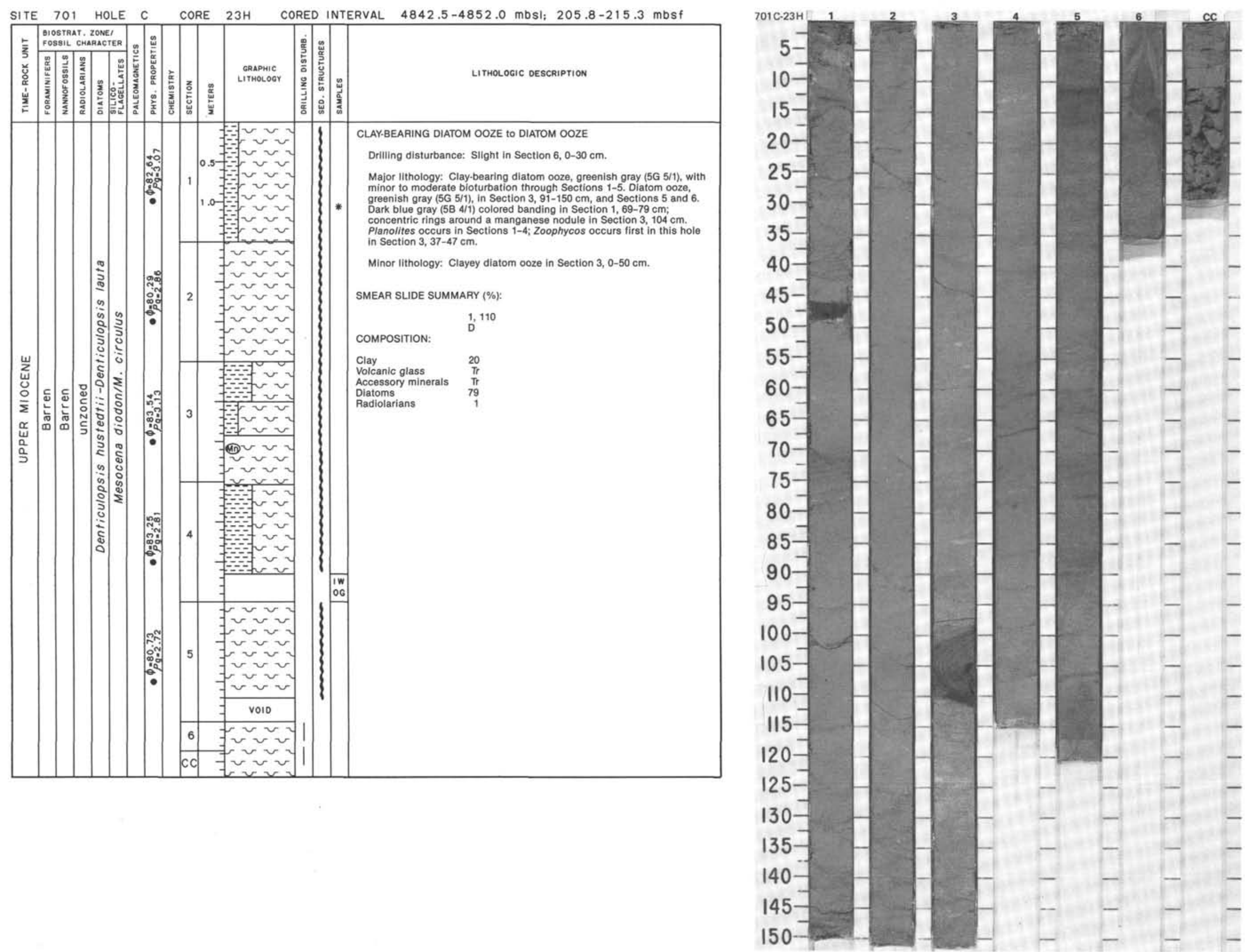

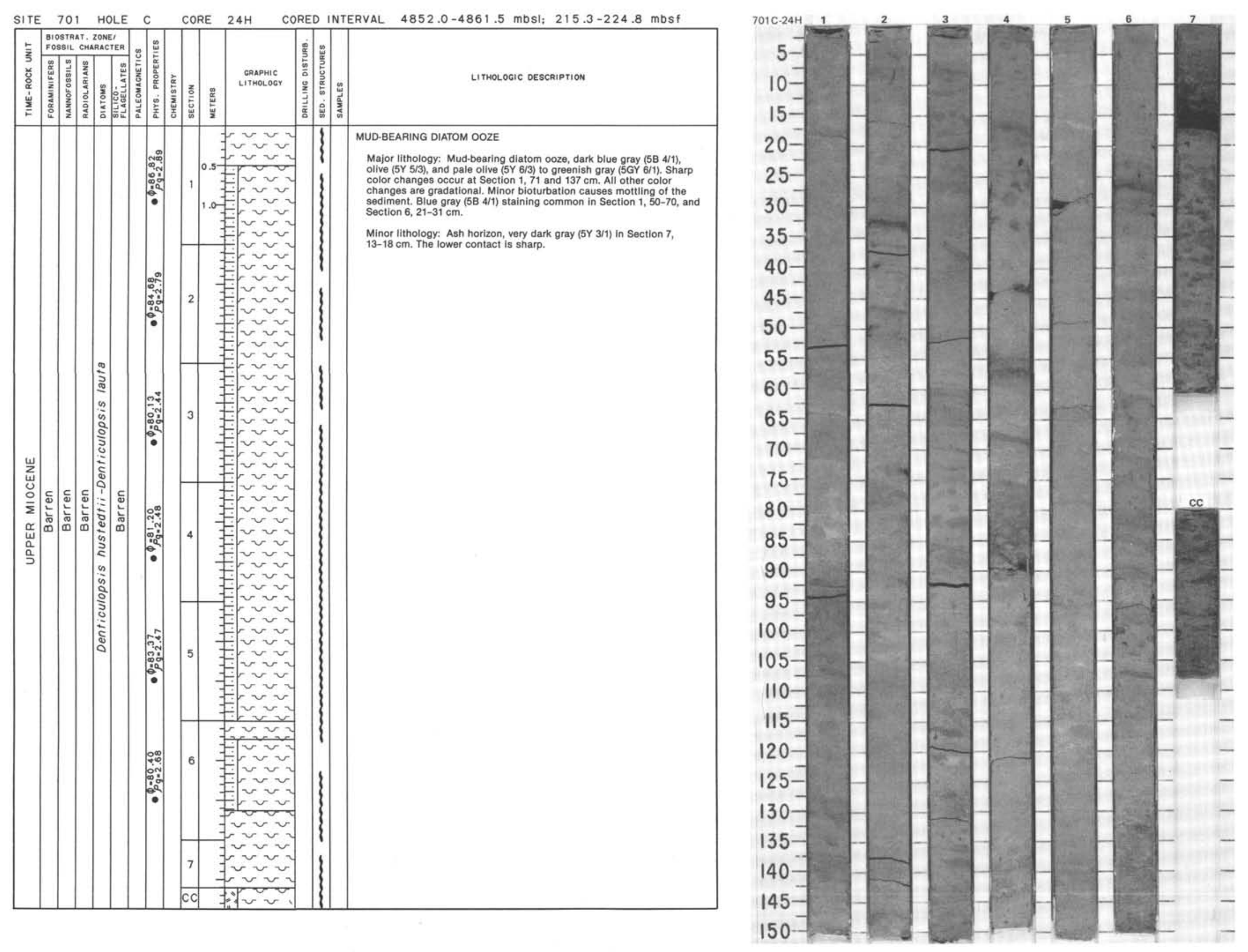

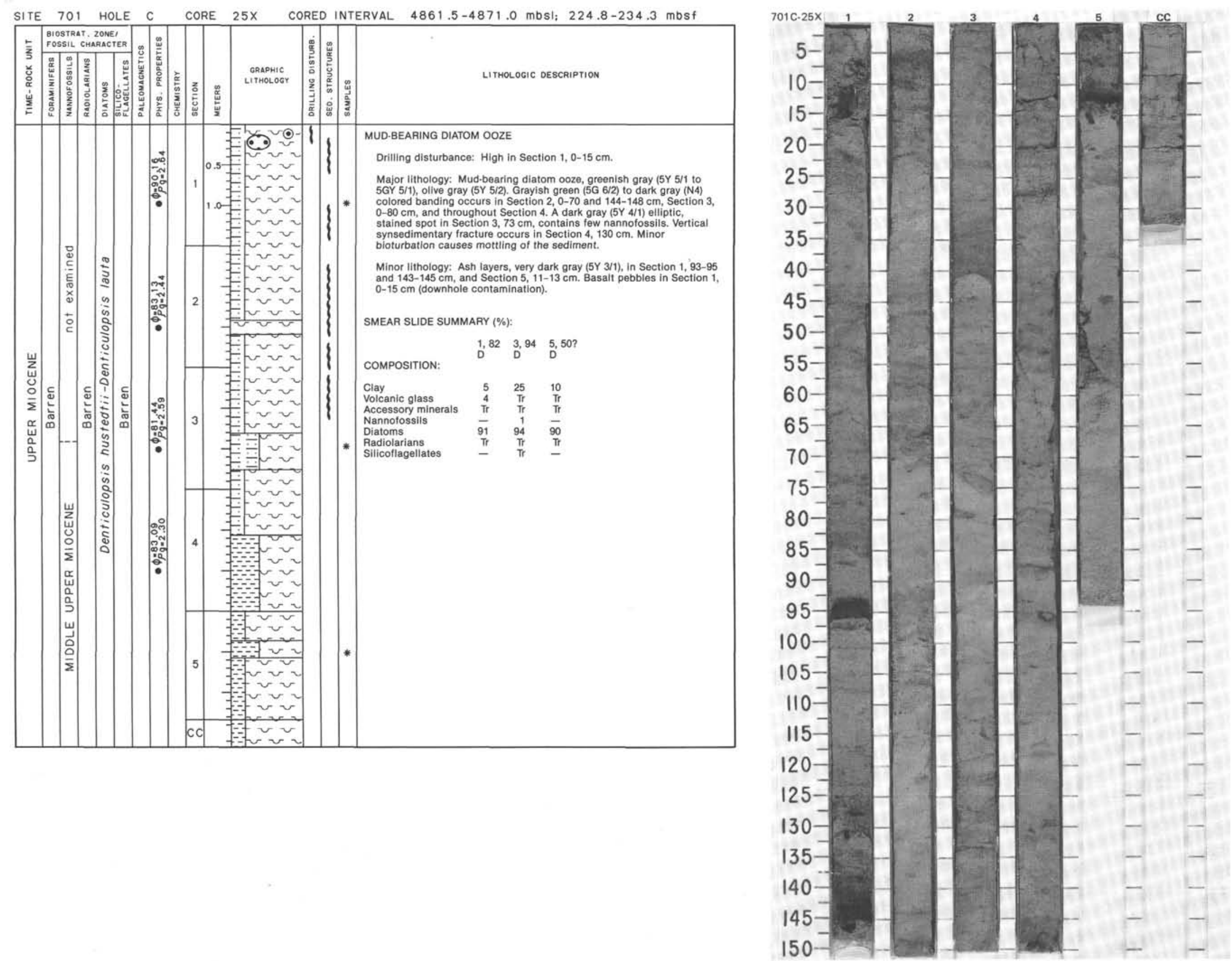


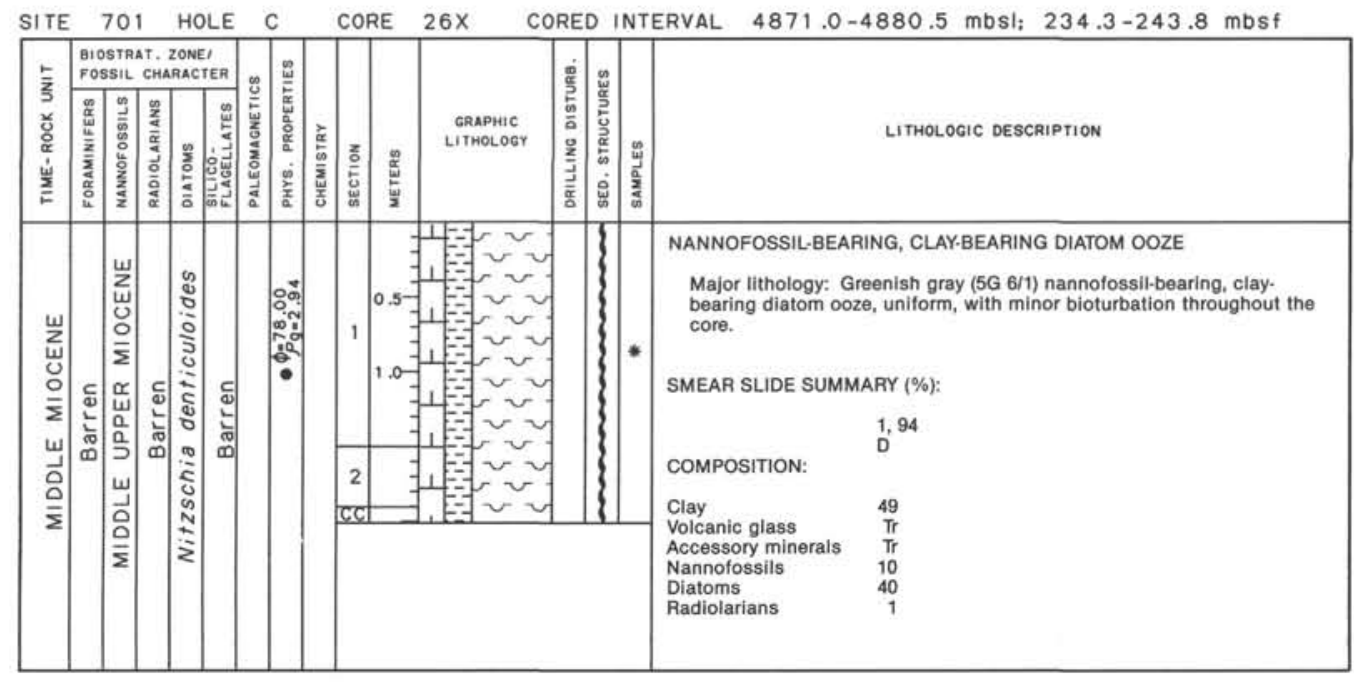

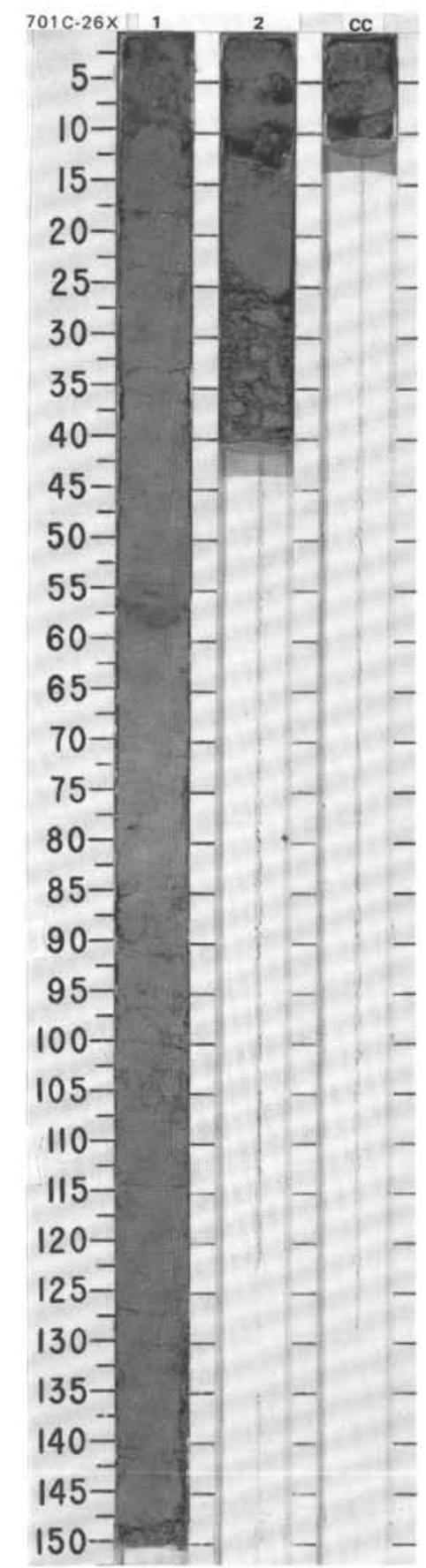



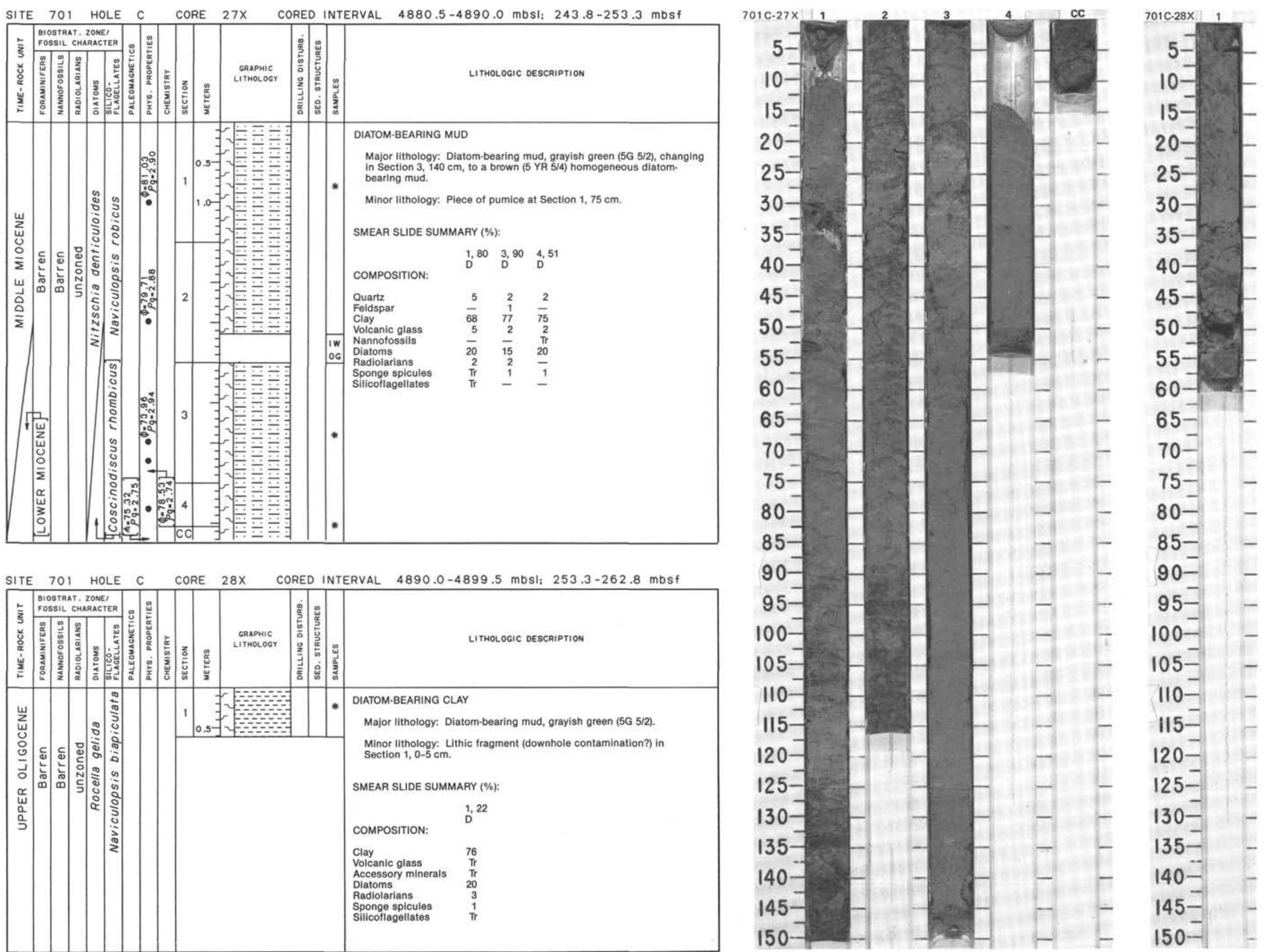

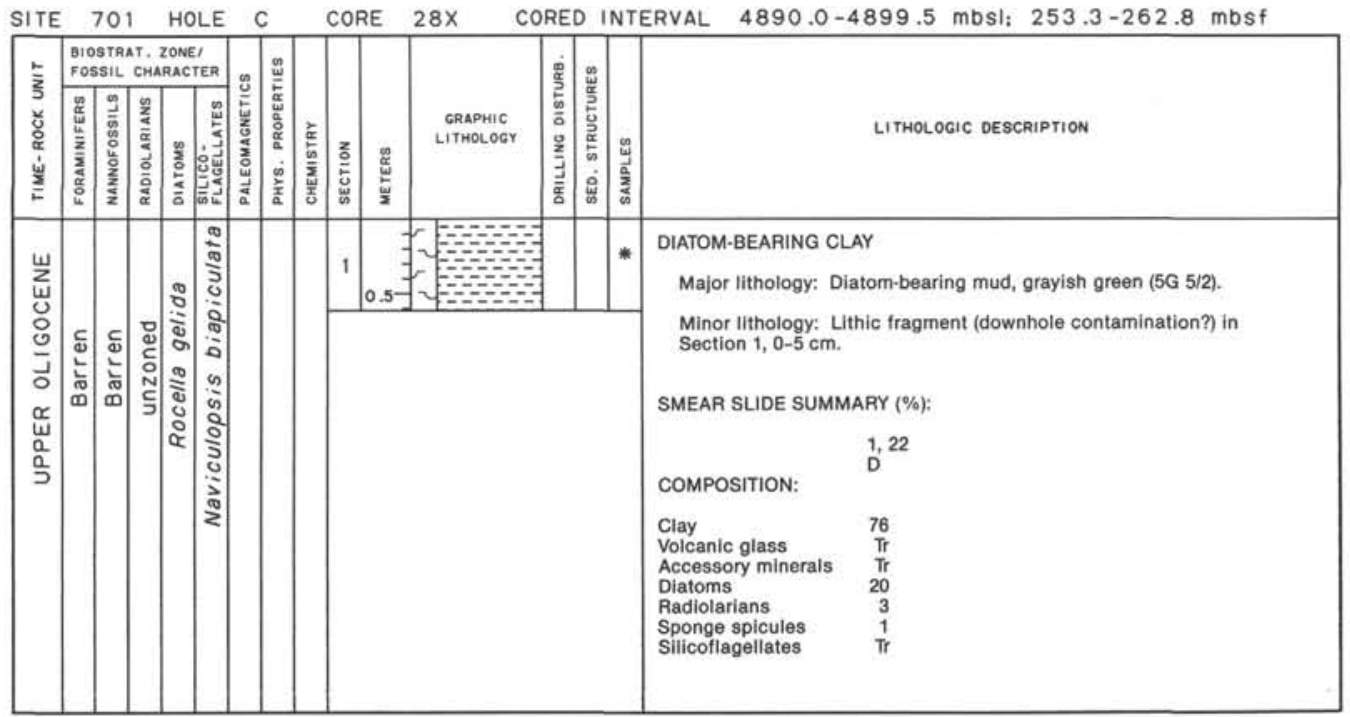



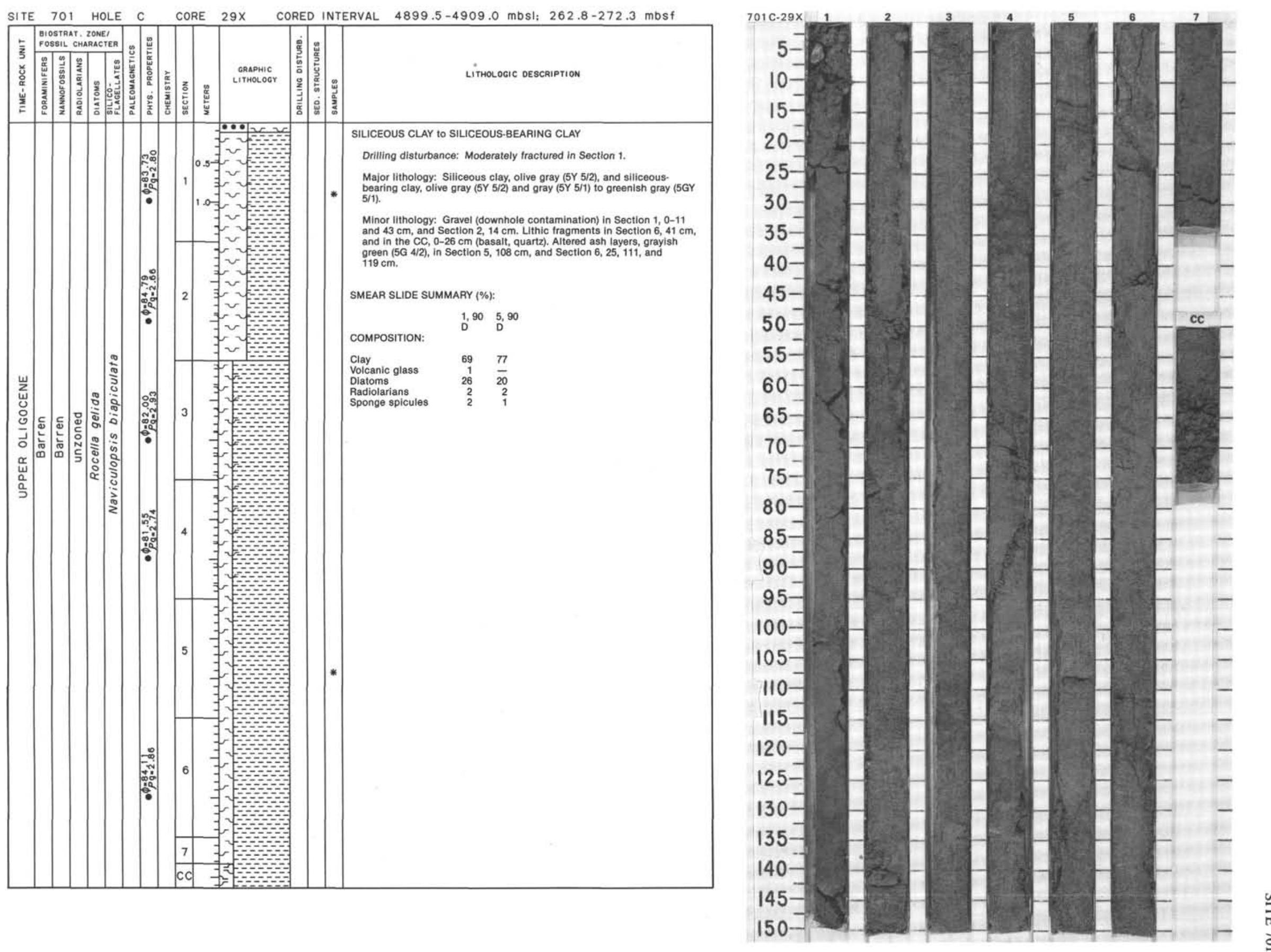


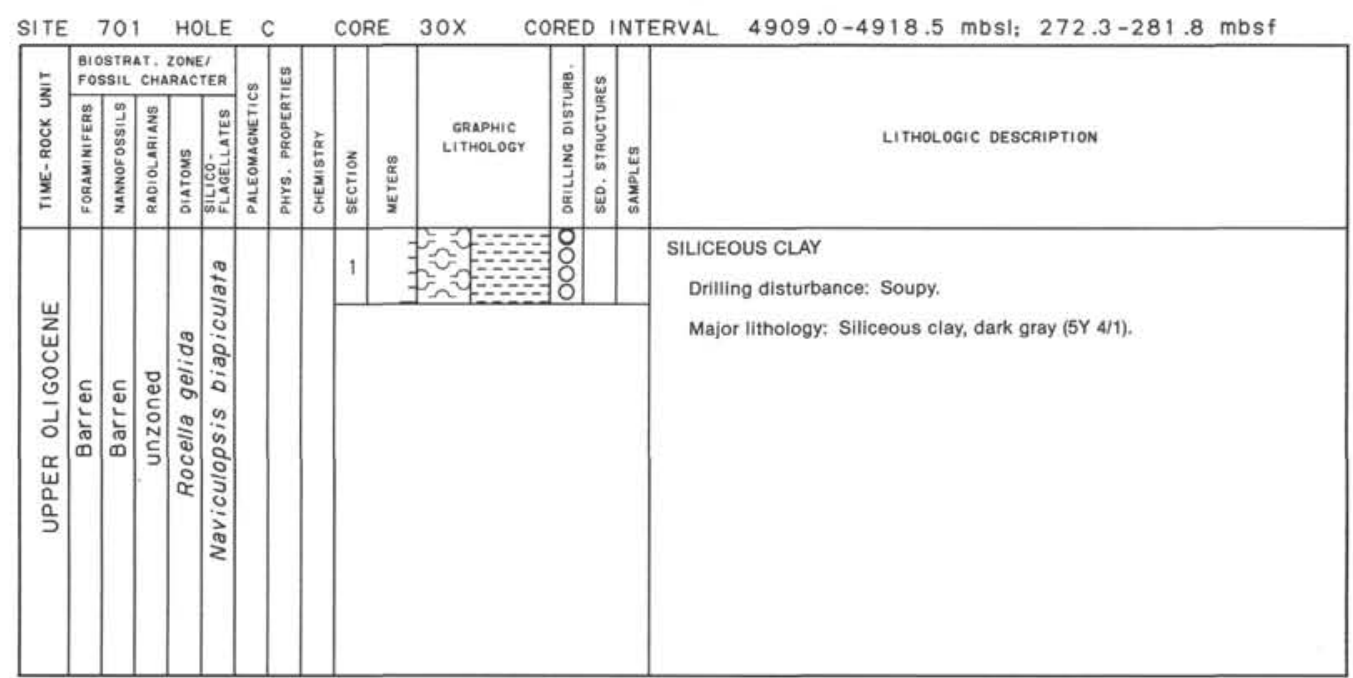

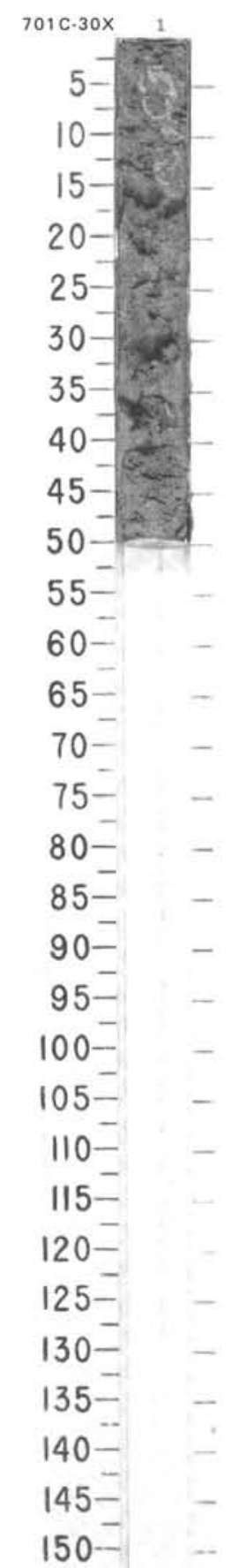



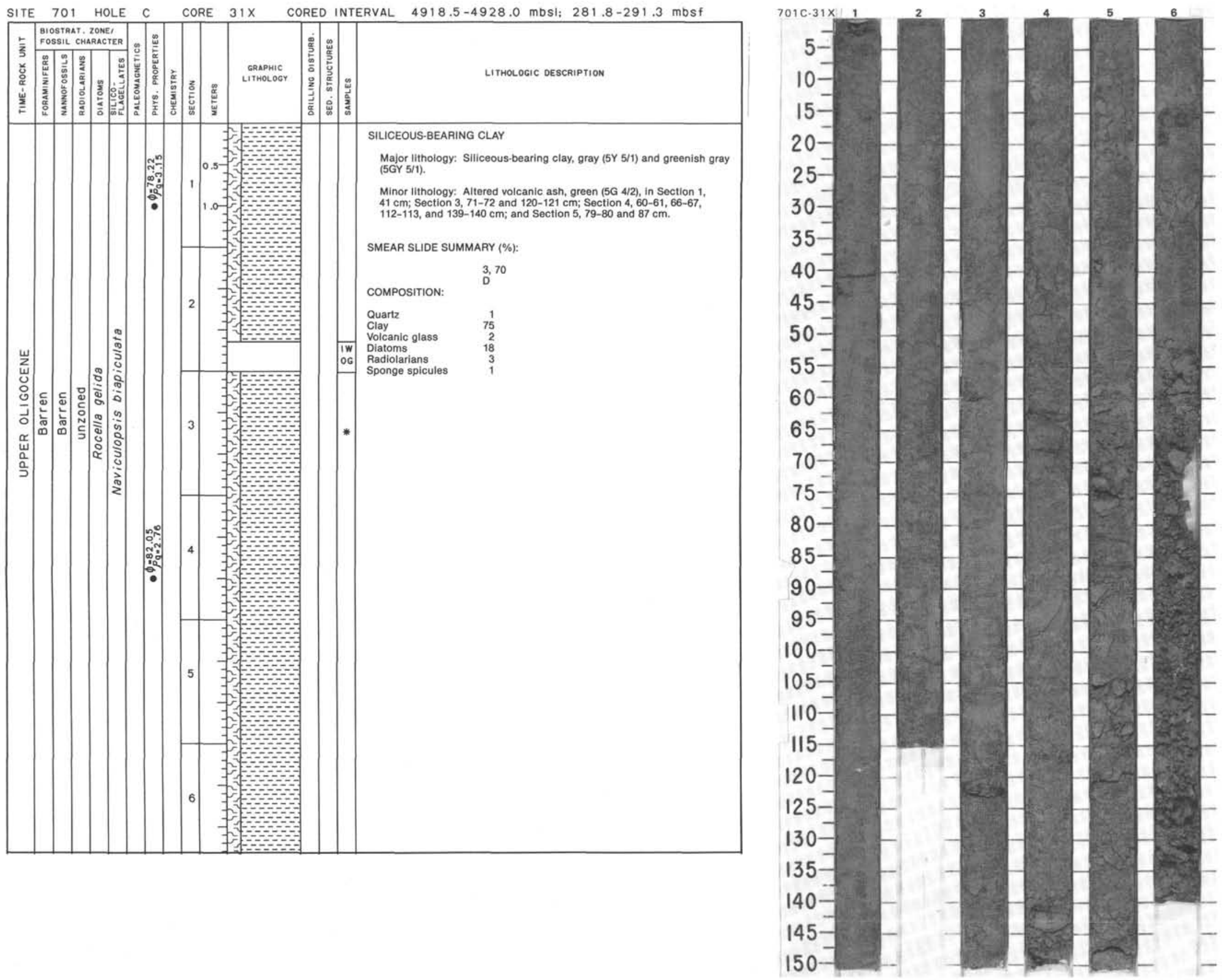

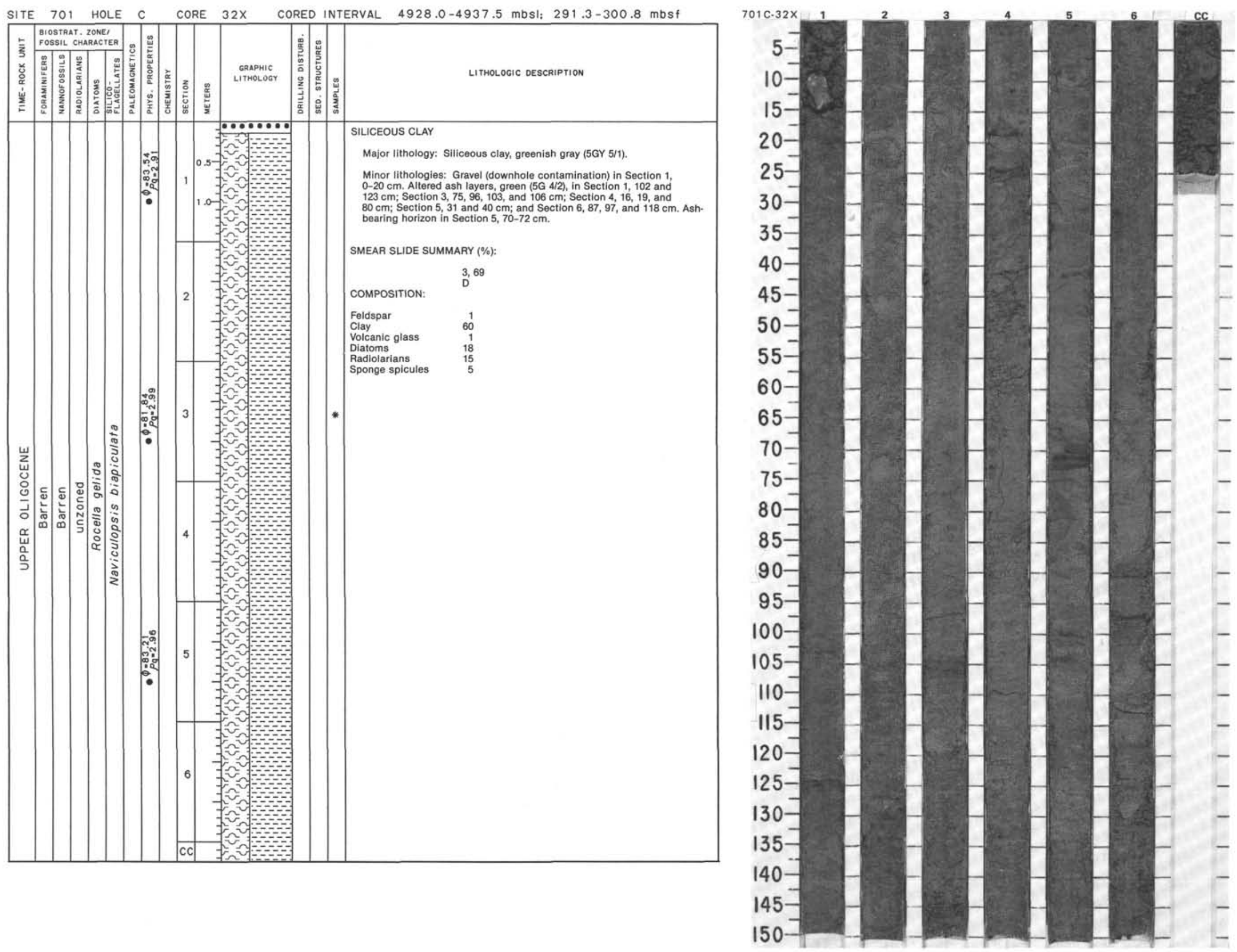


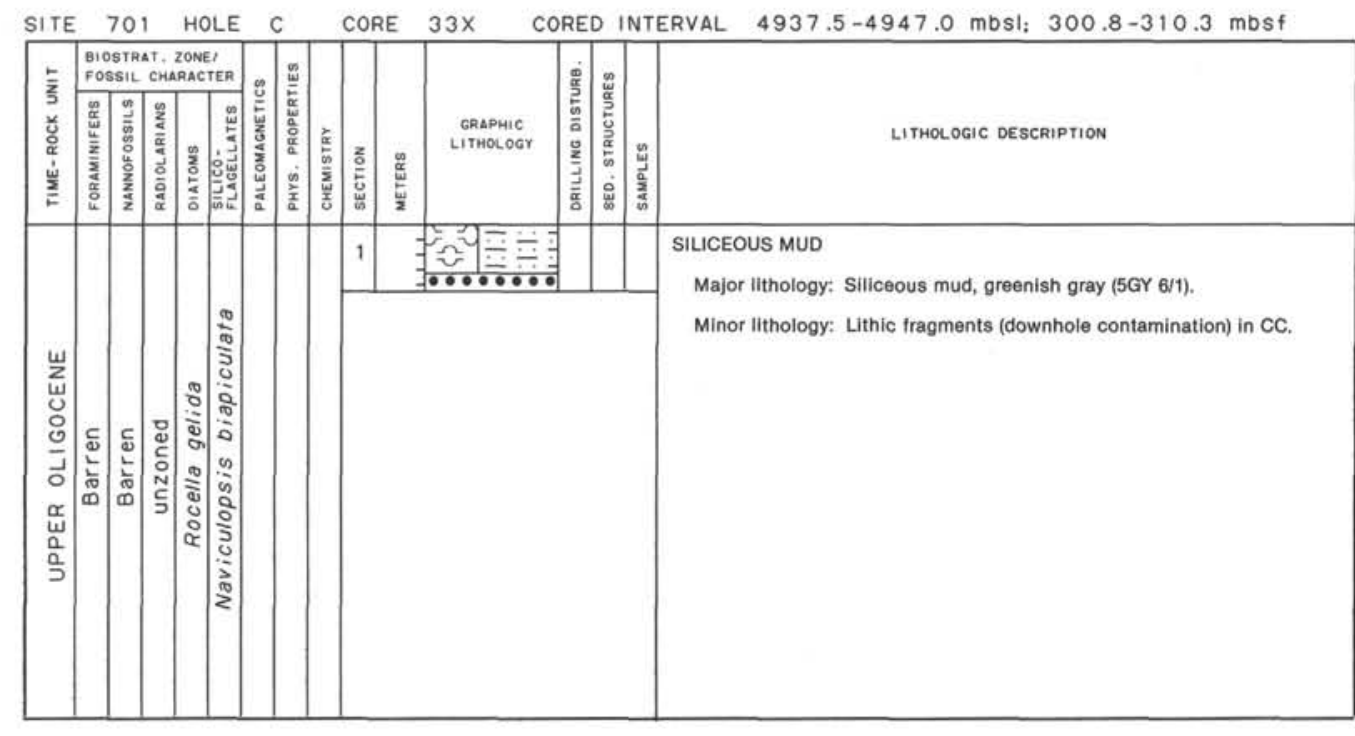

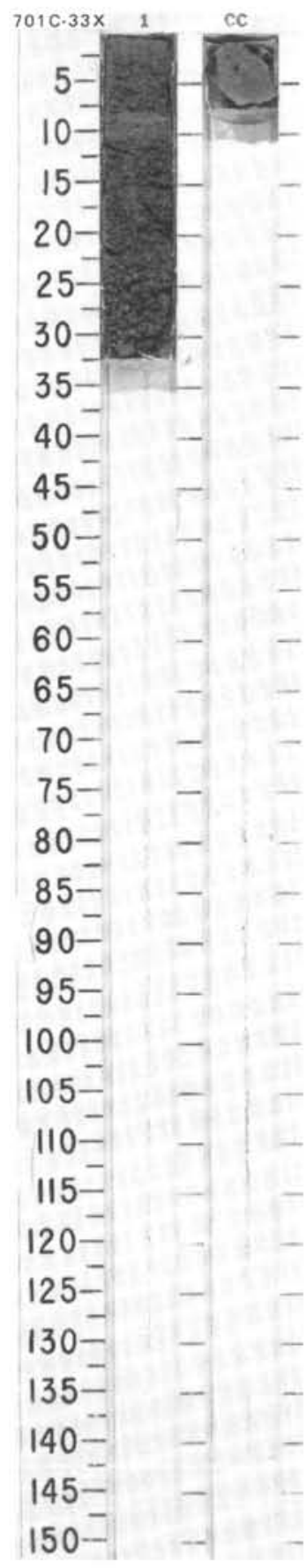



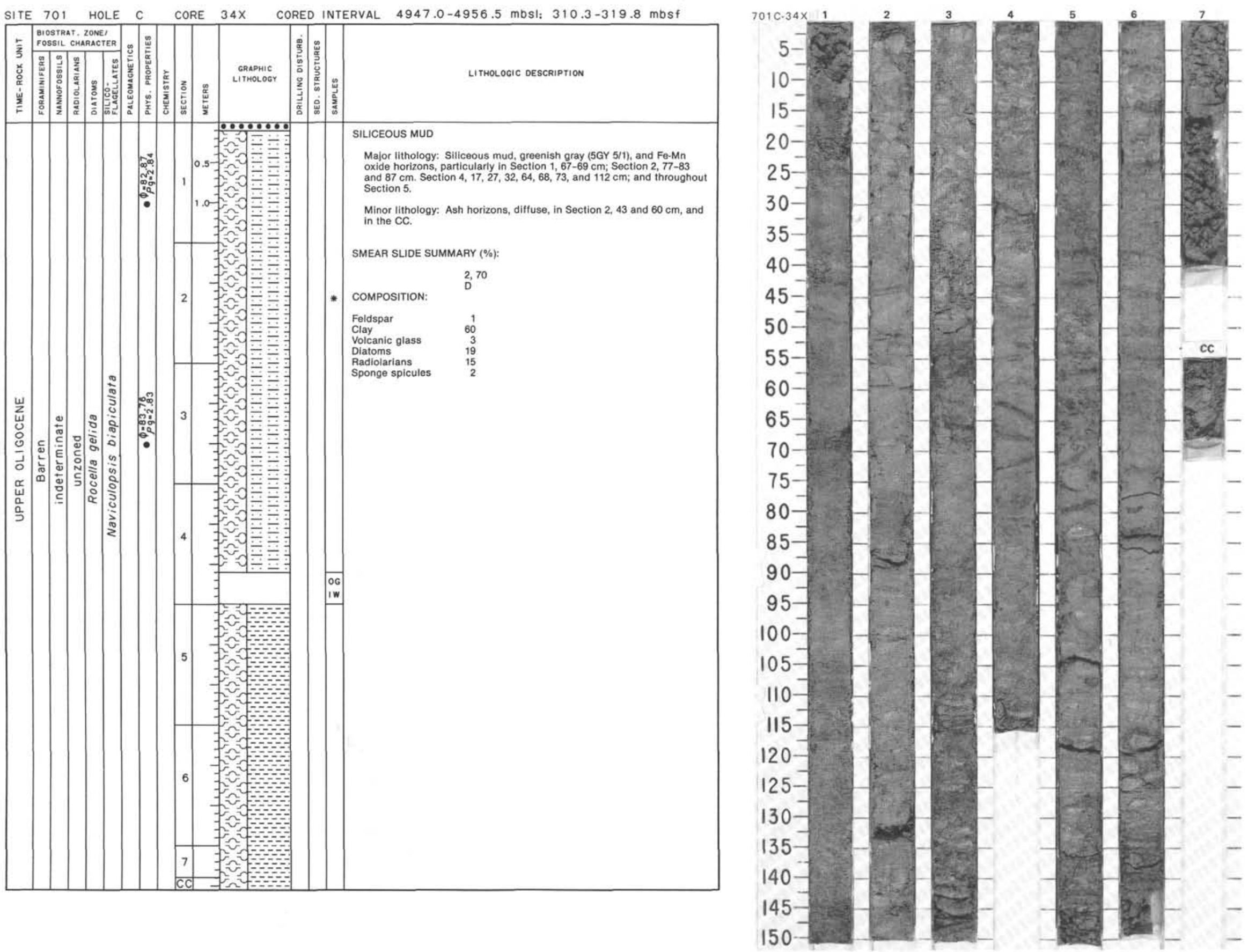

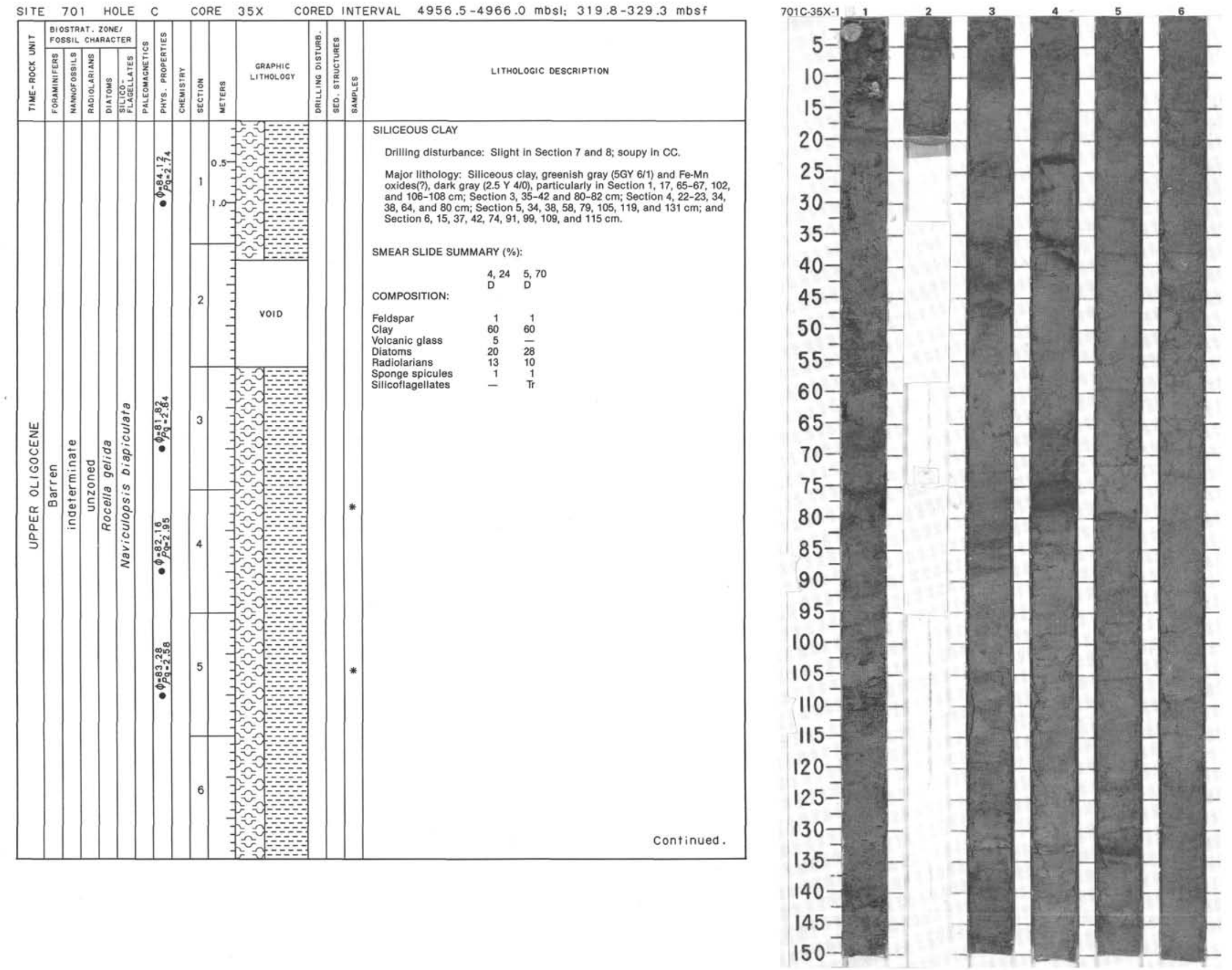

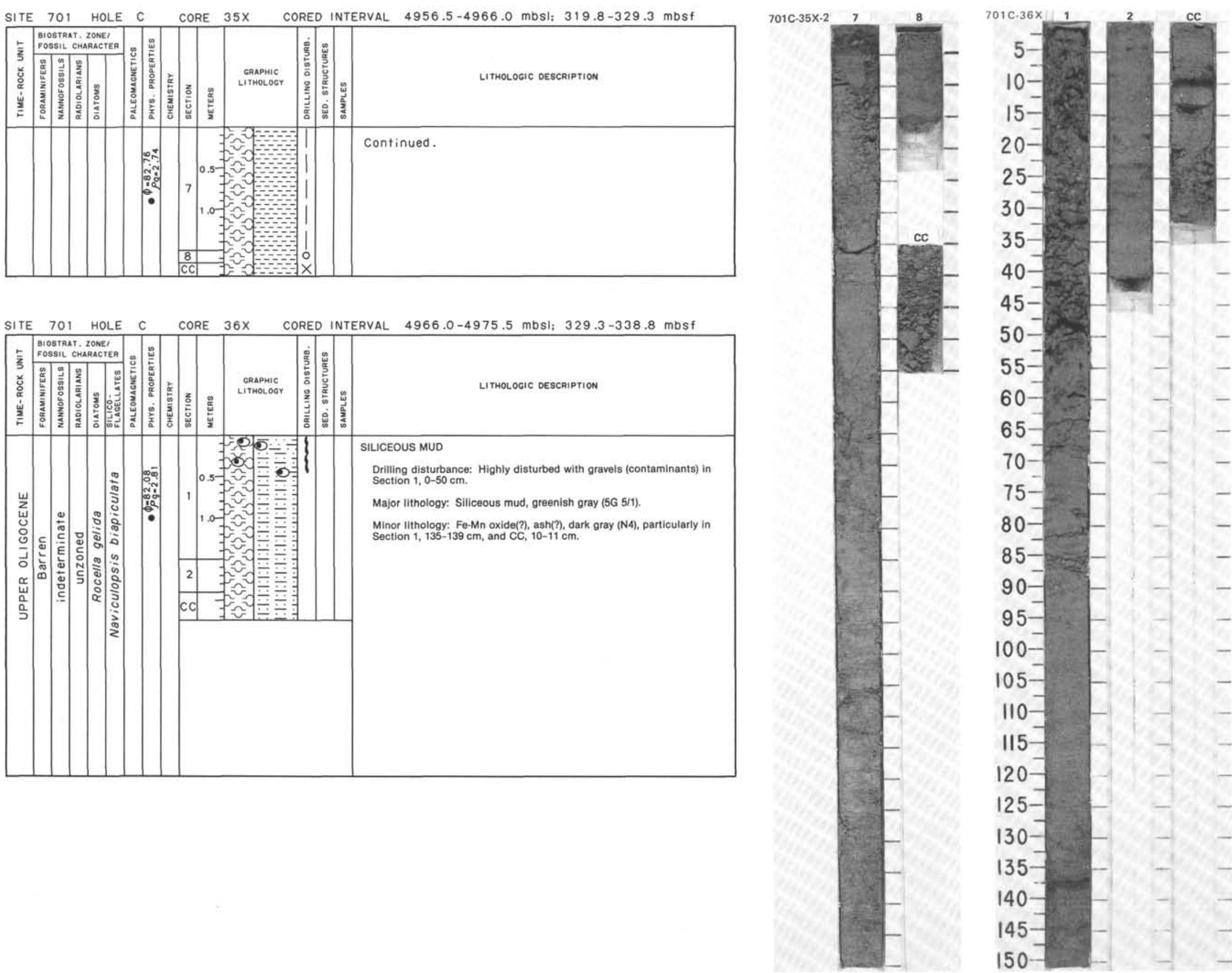

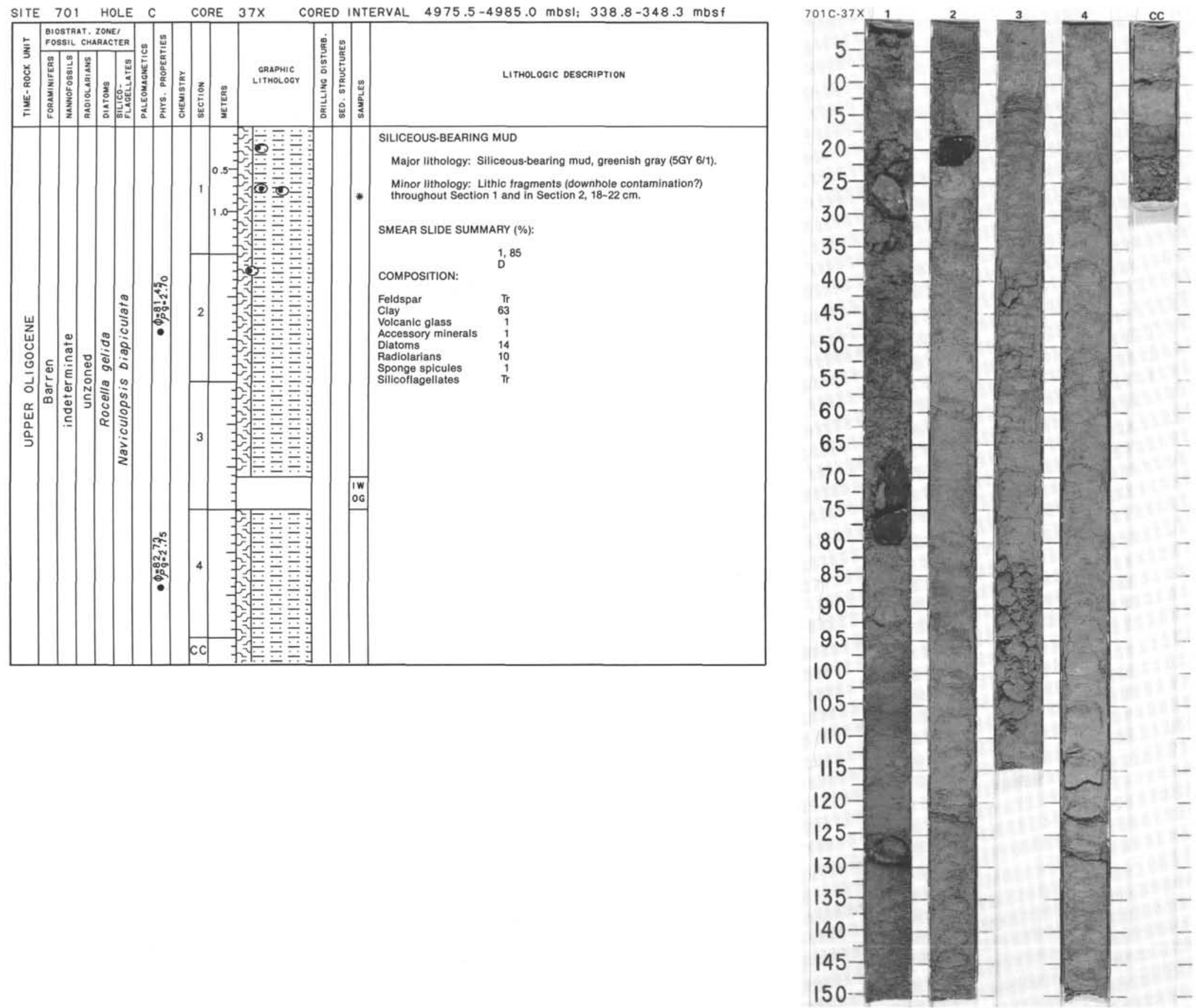

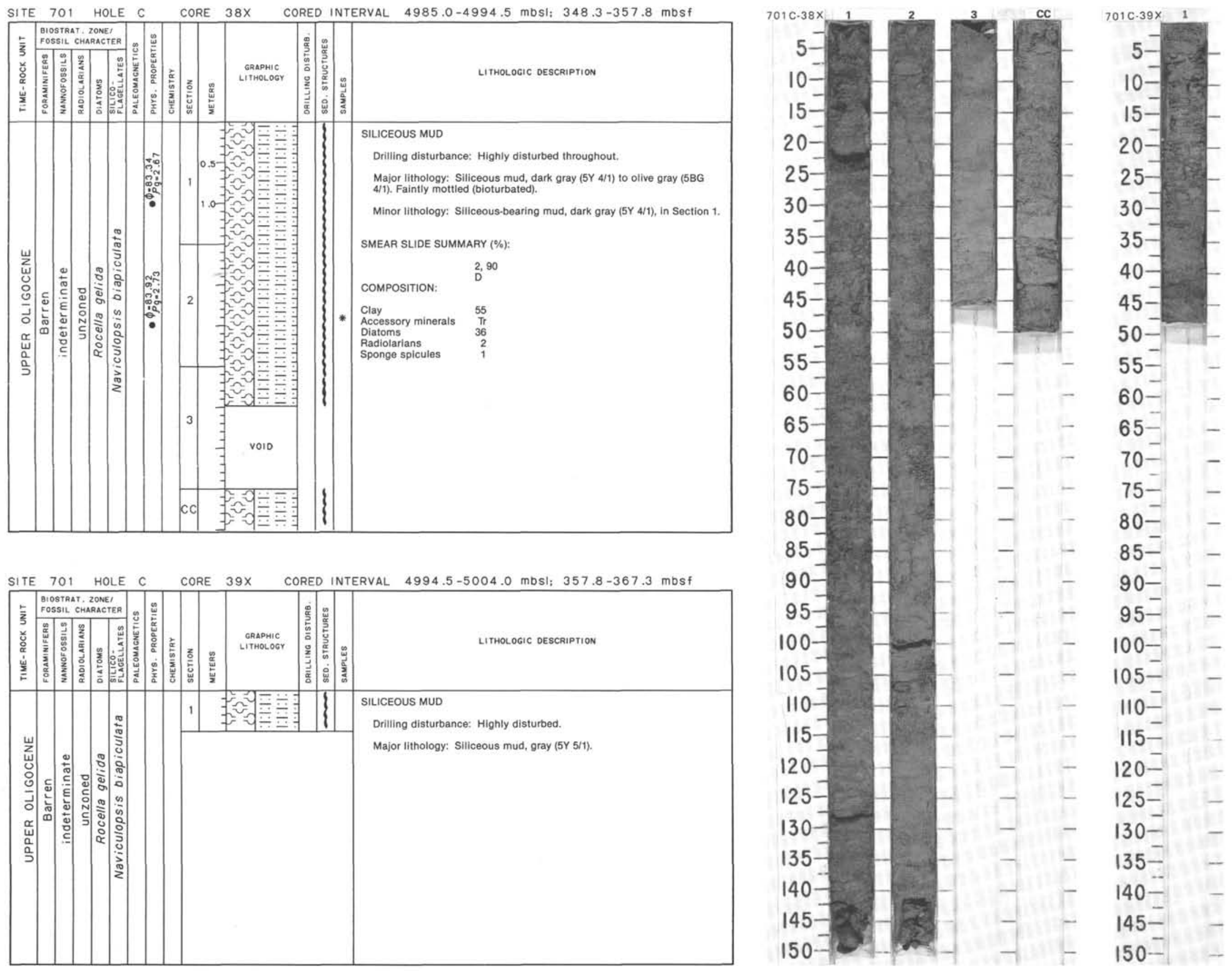

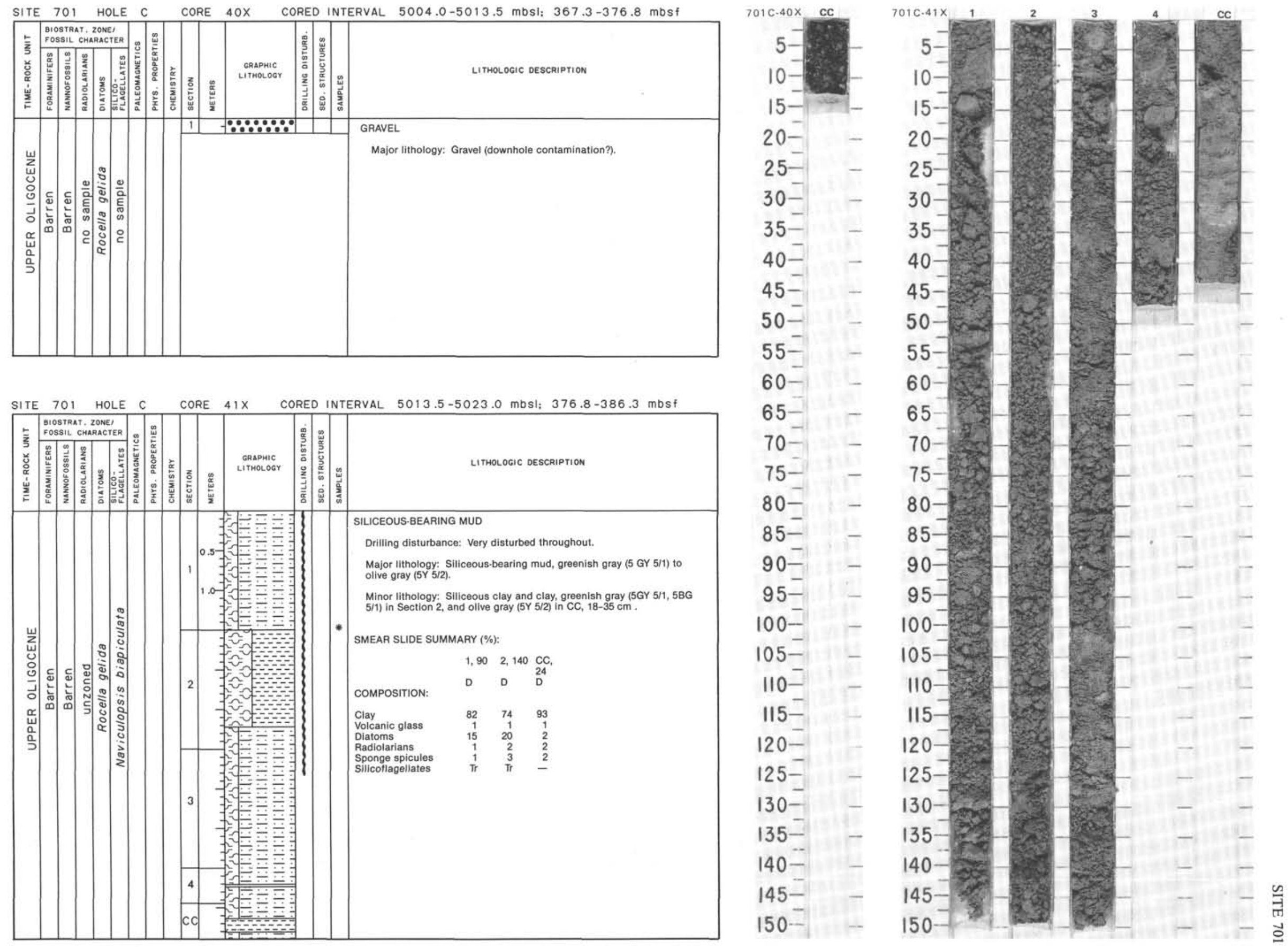

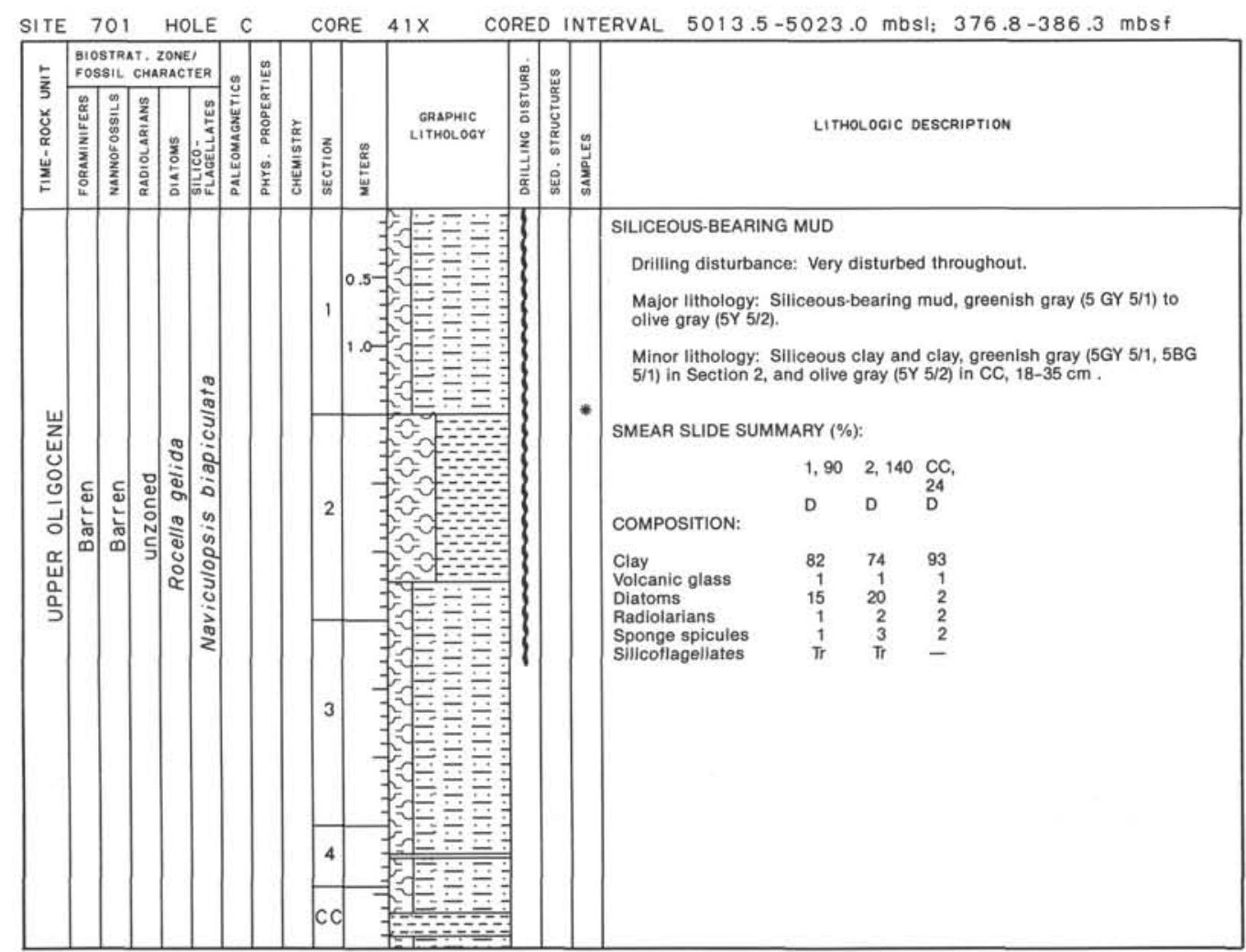




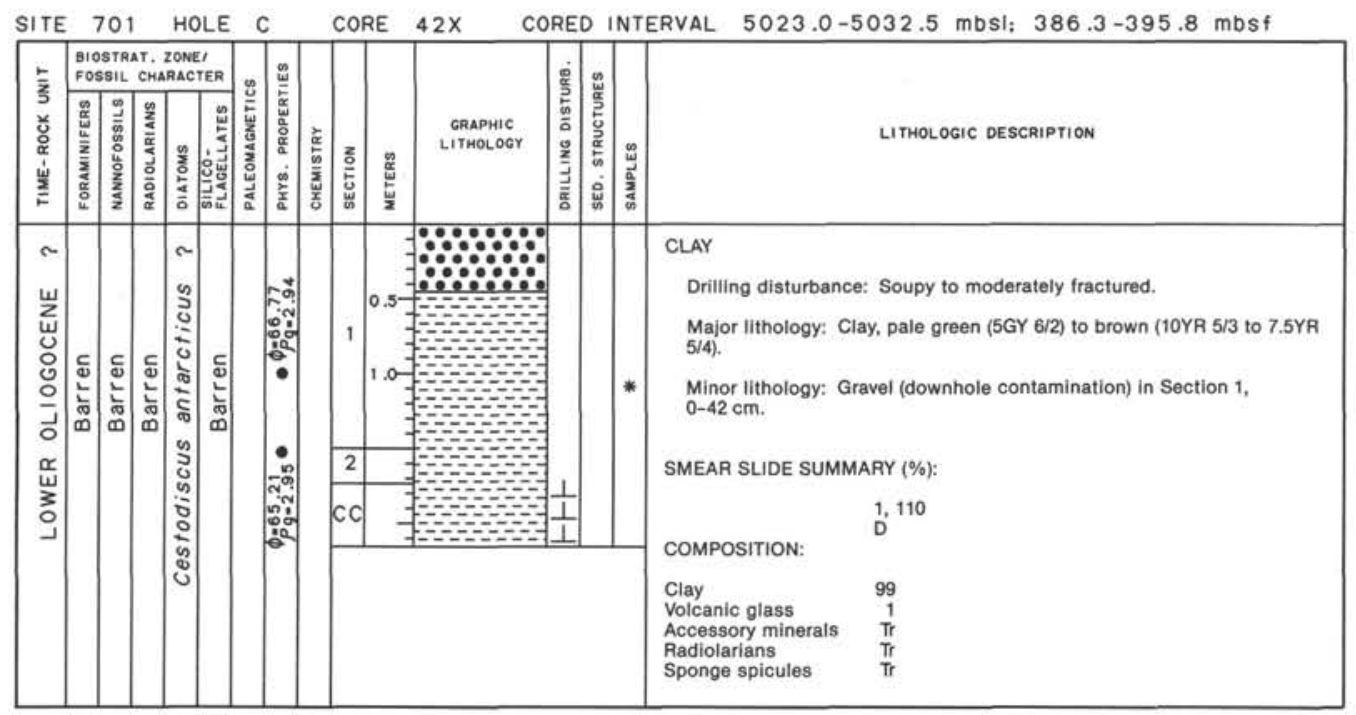

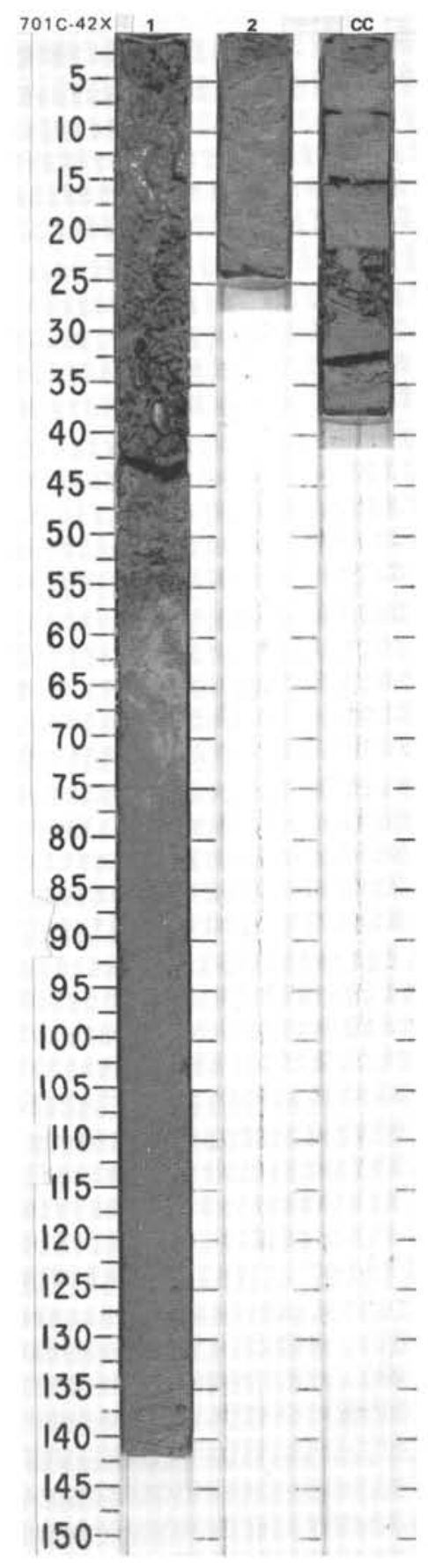




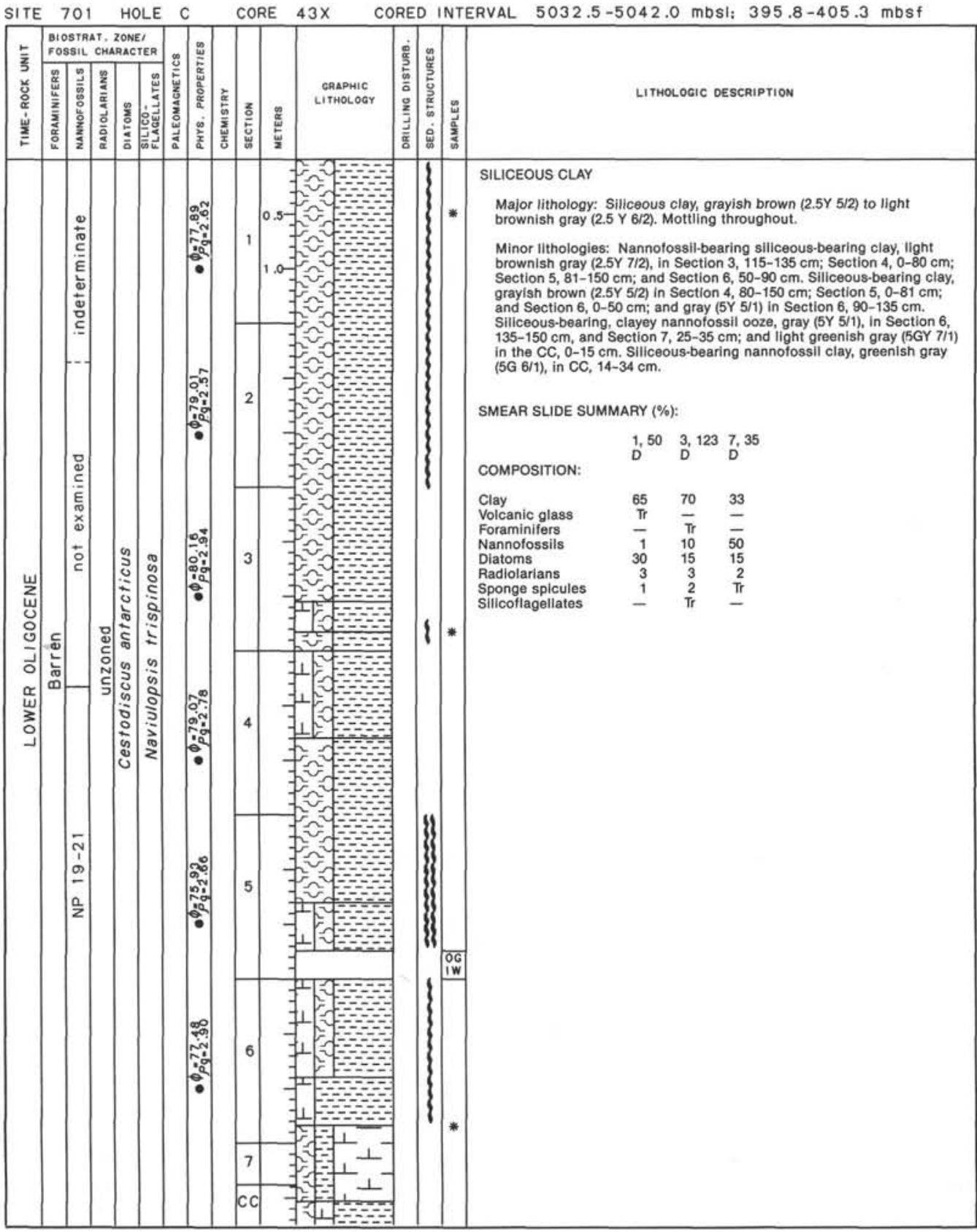

ज

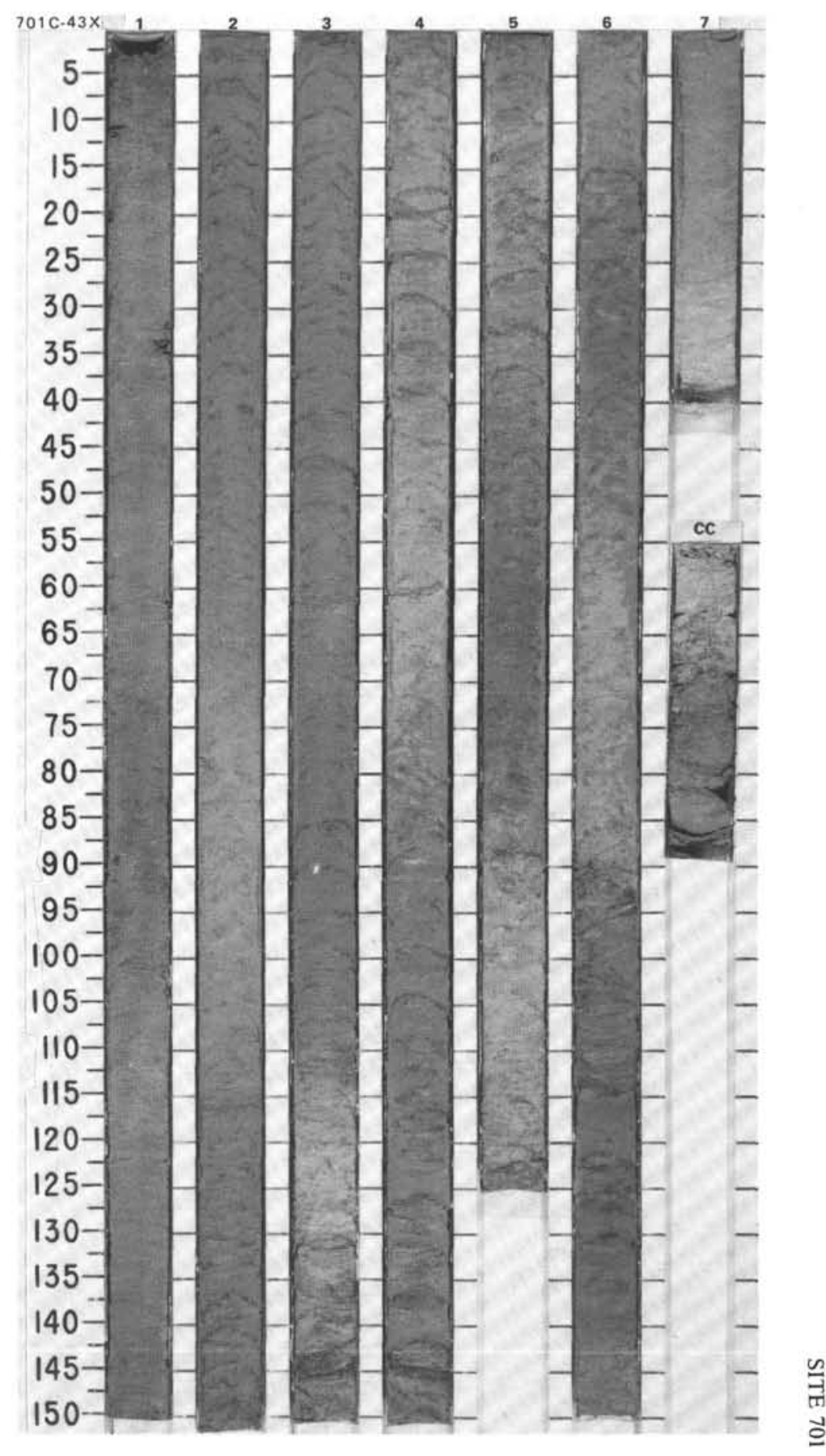



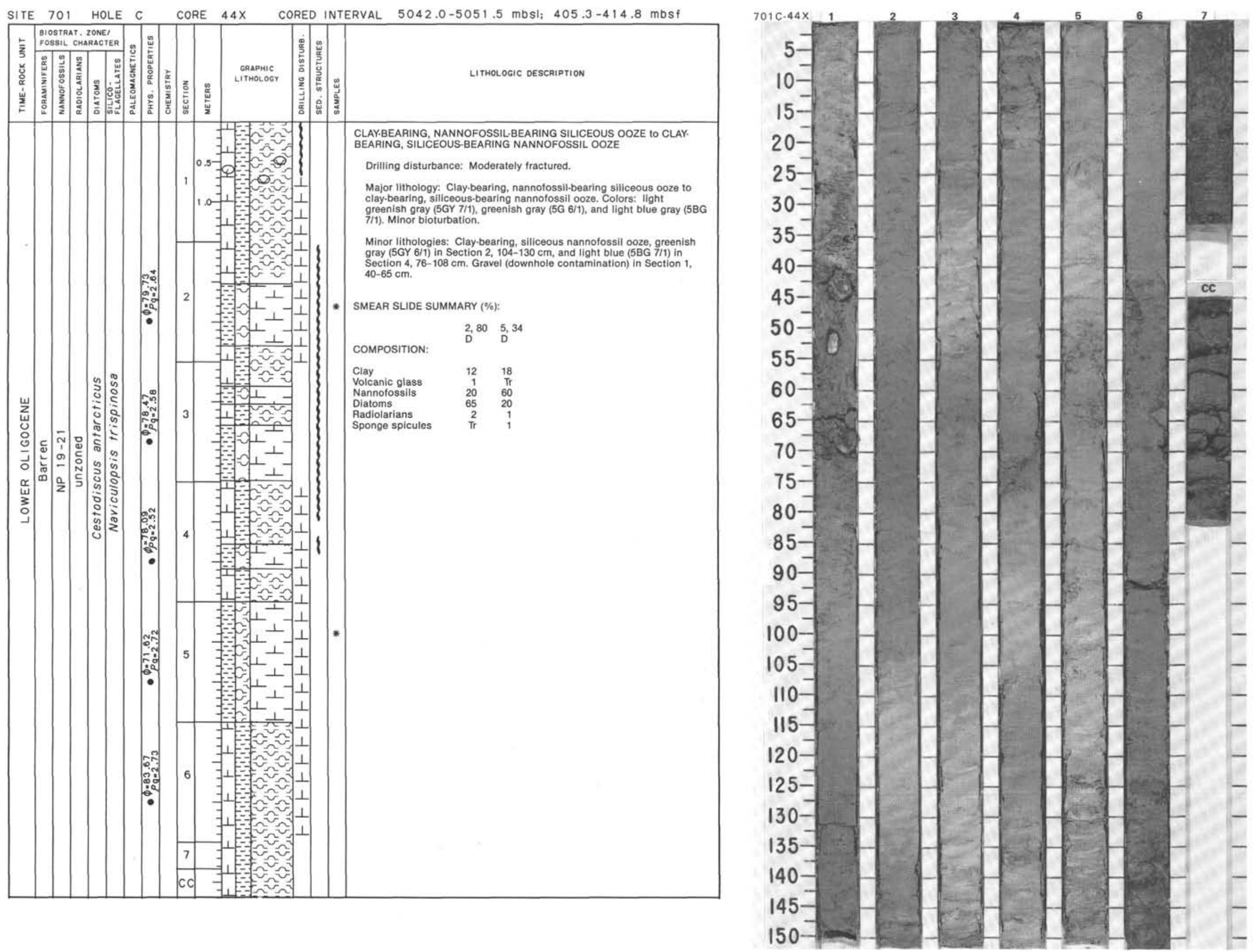

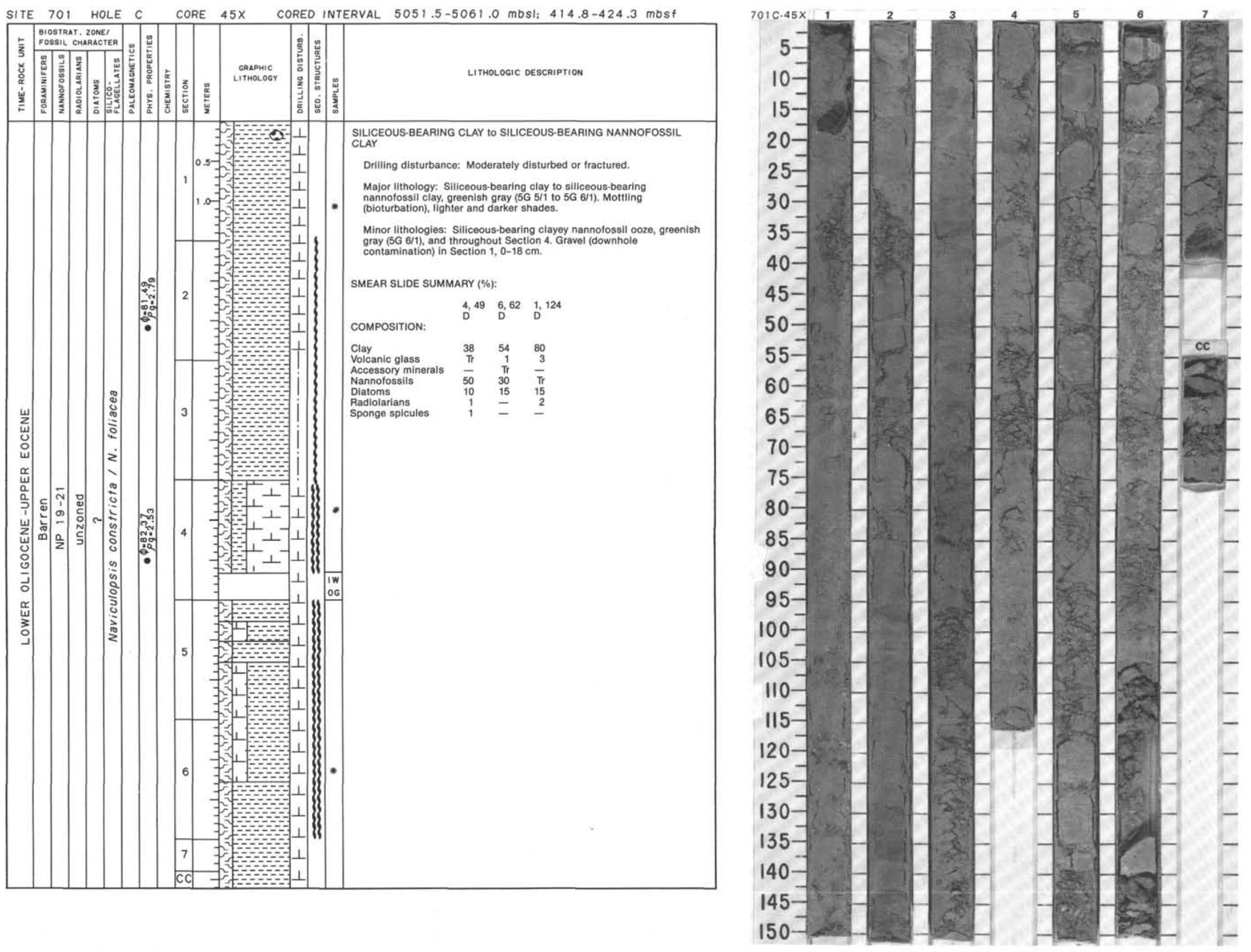

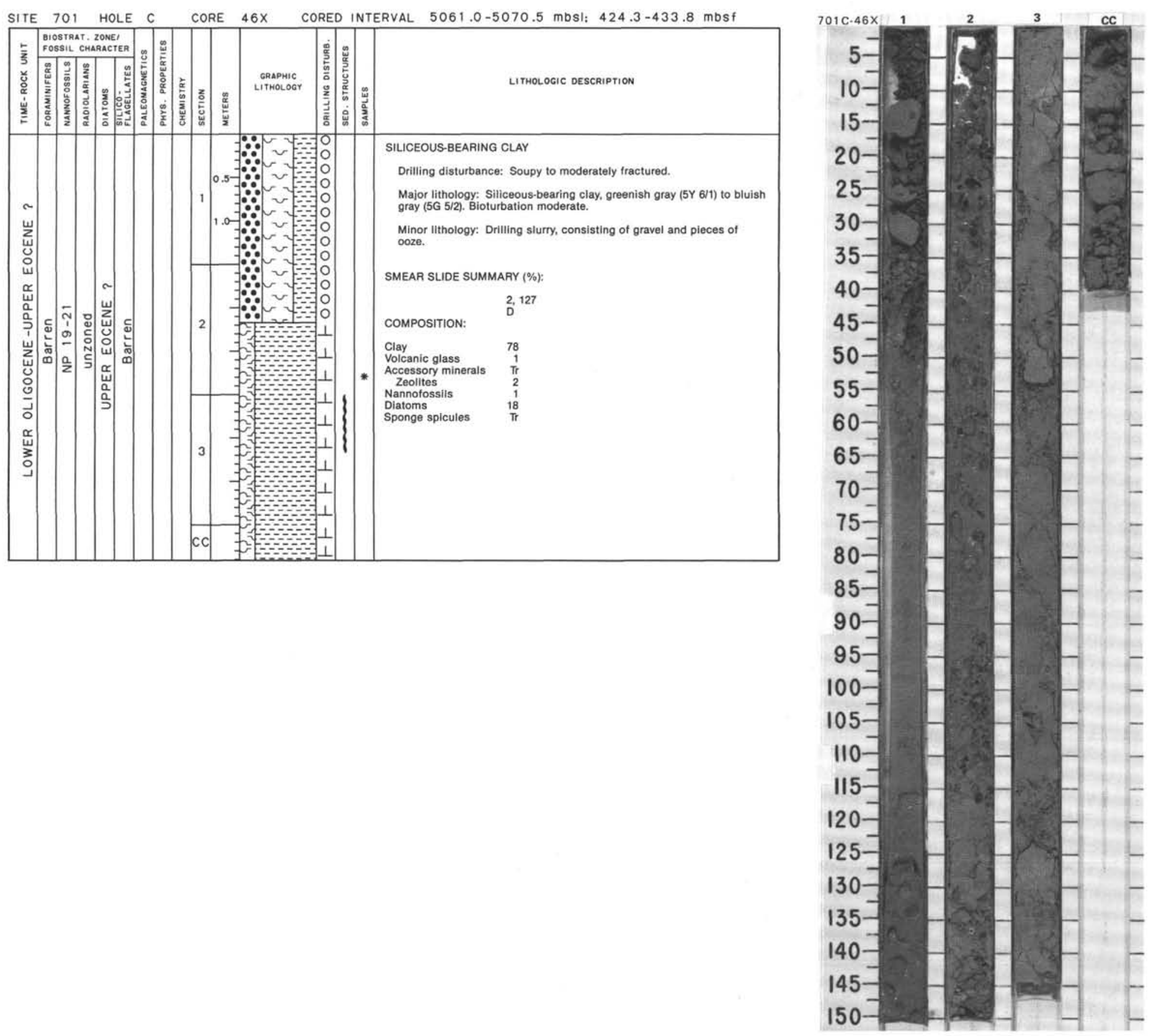

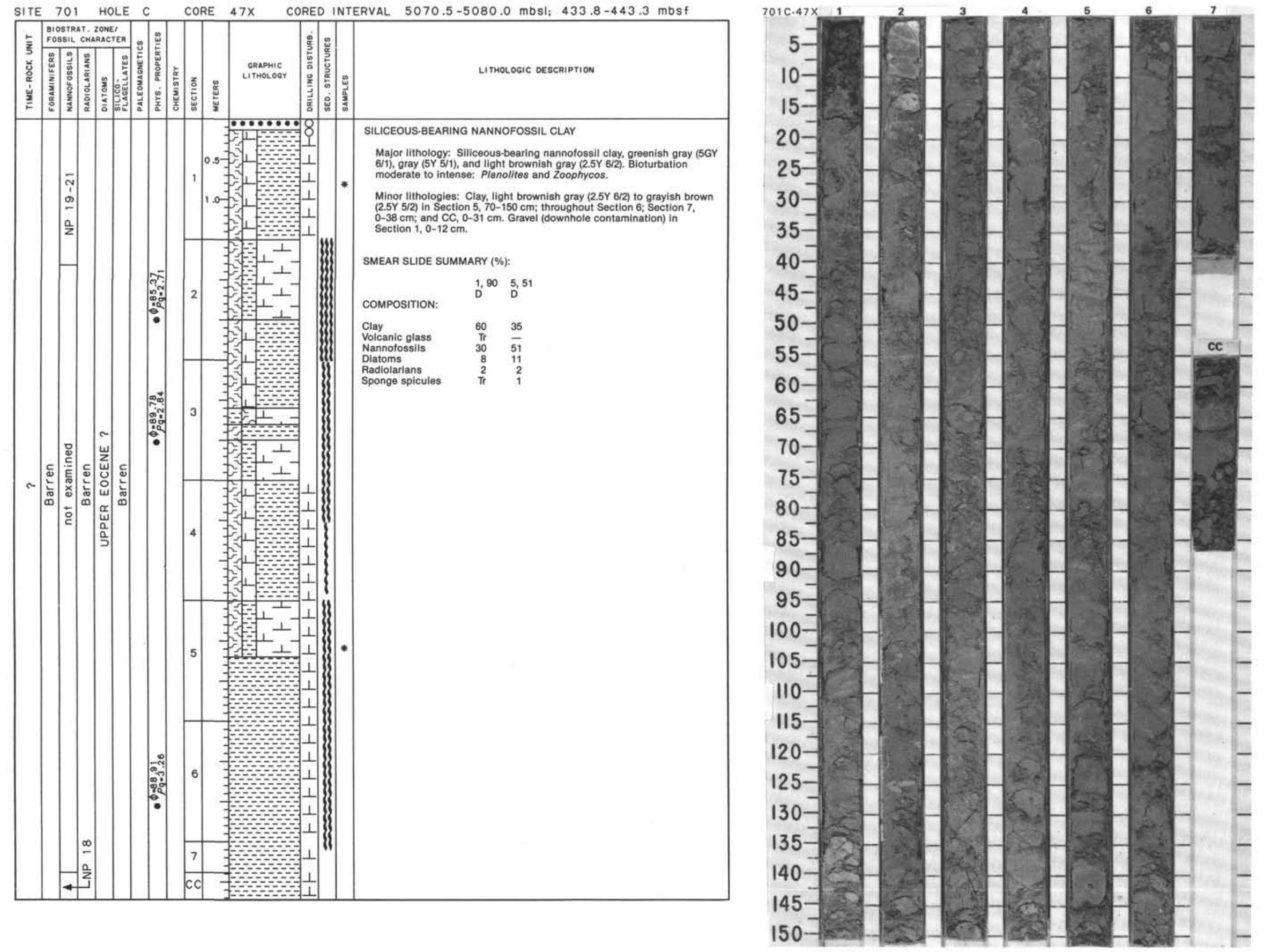

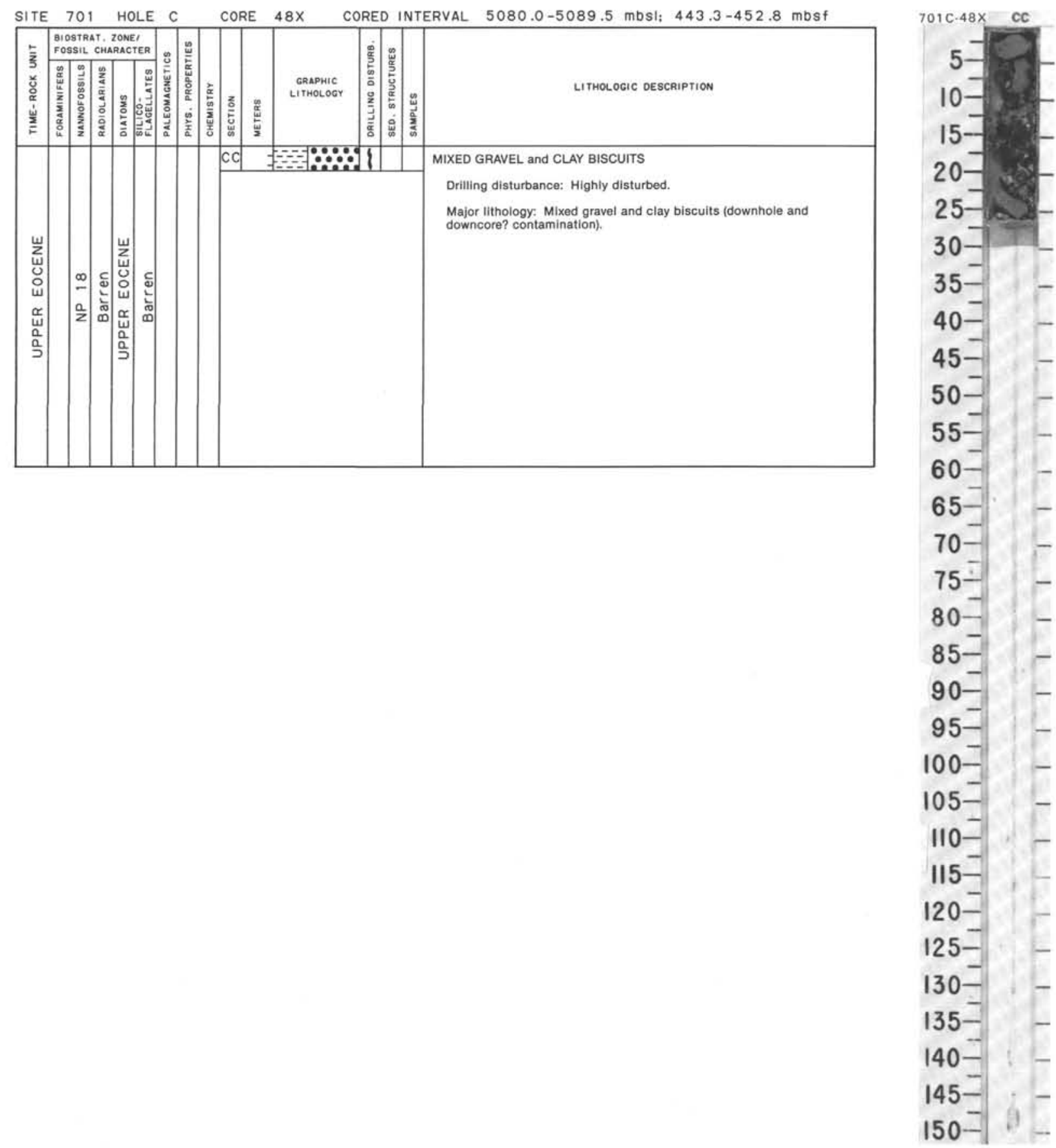

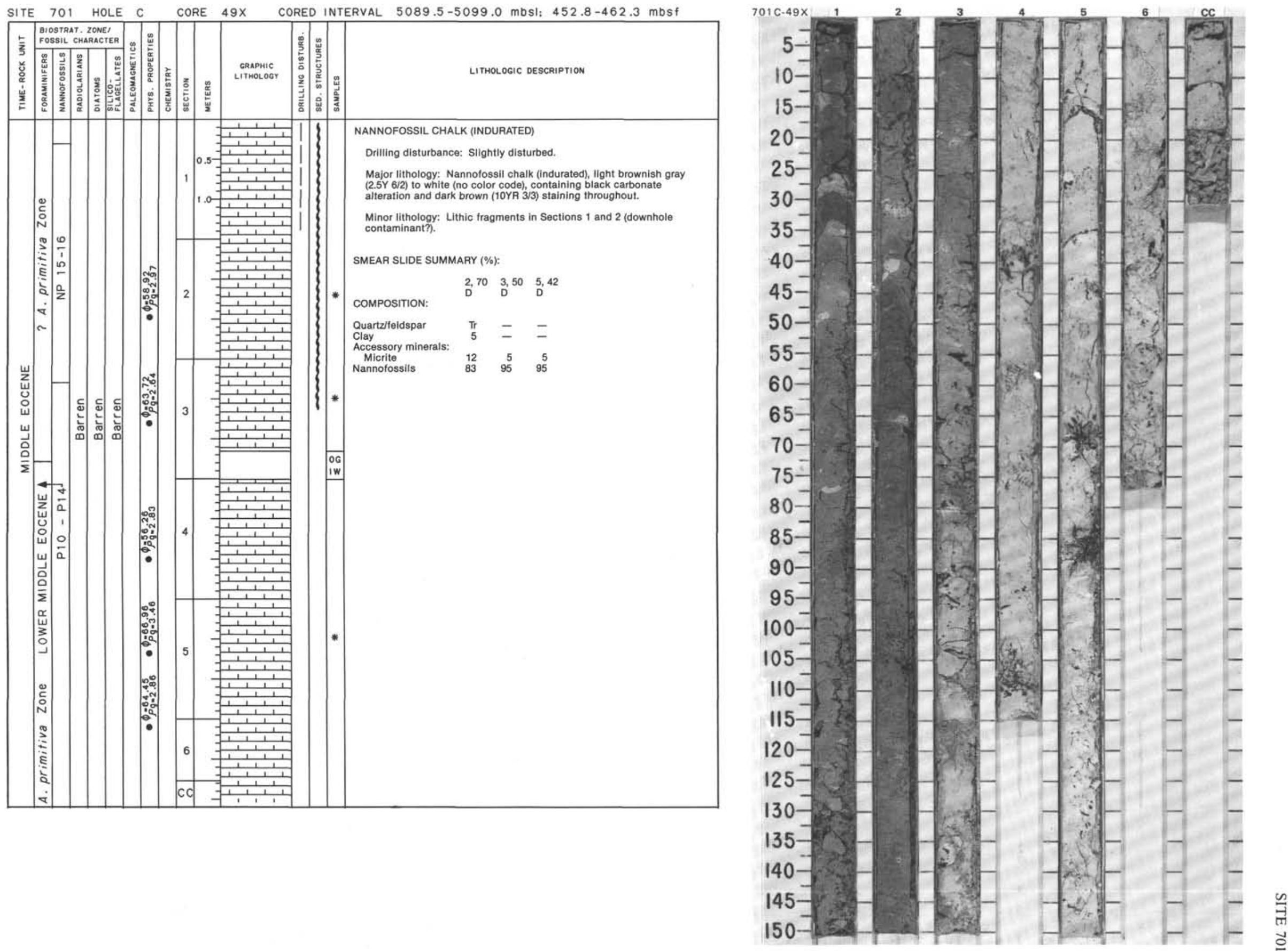

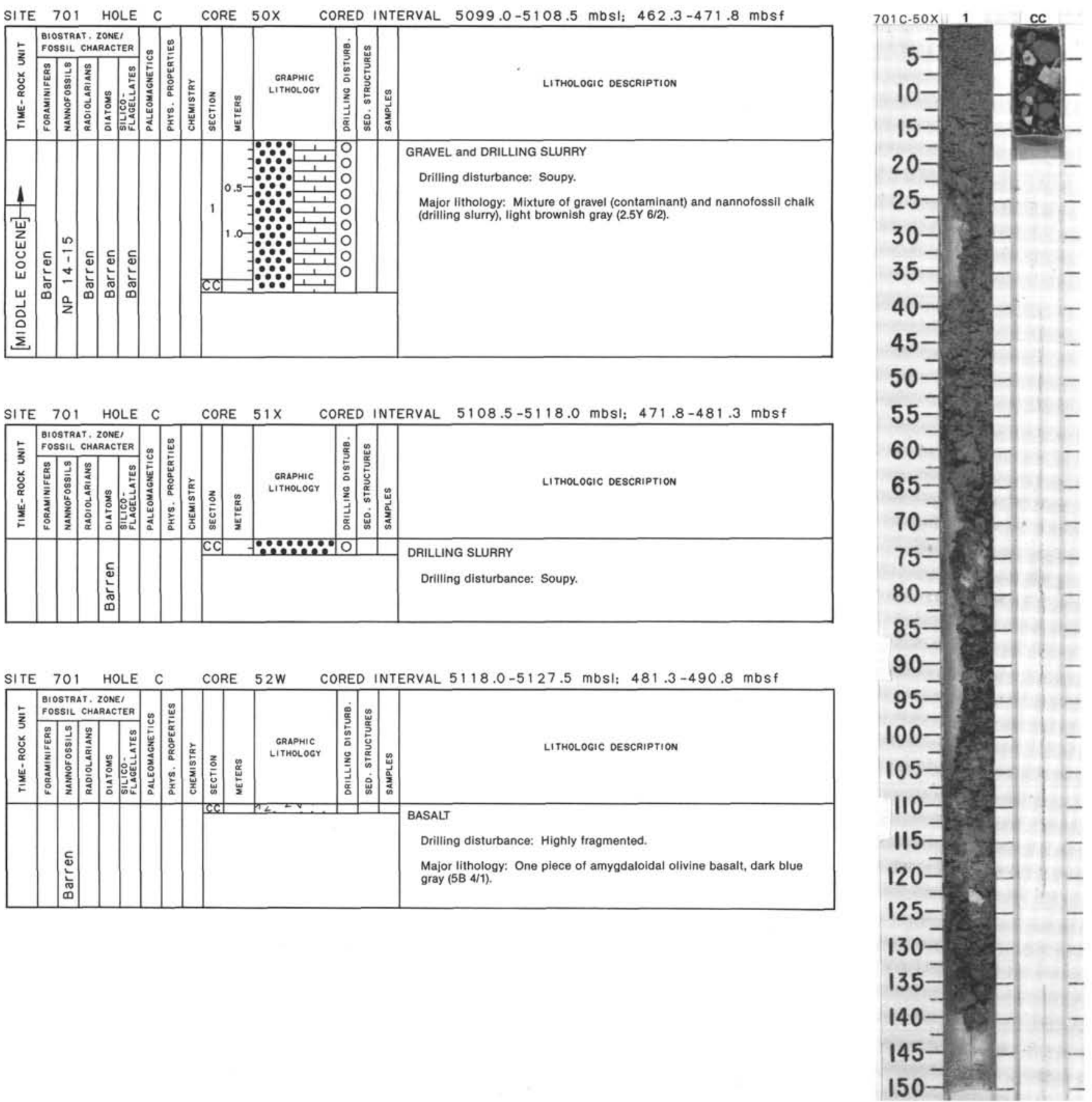

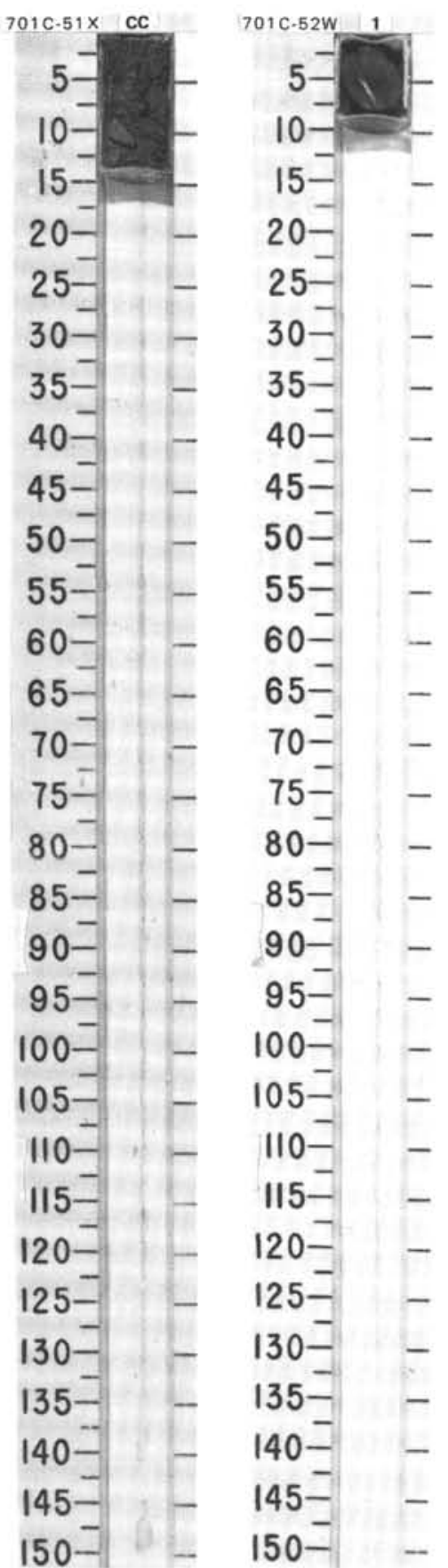
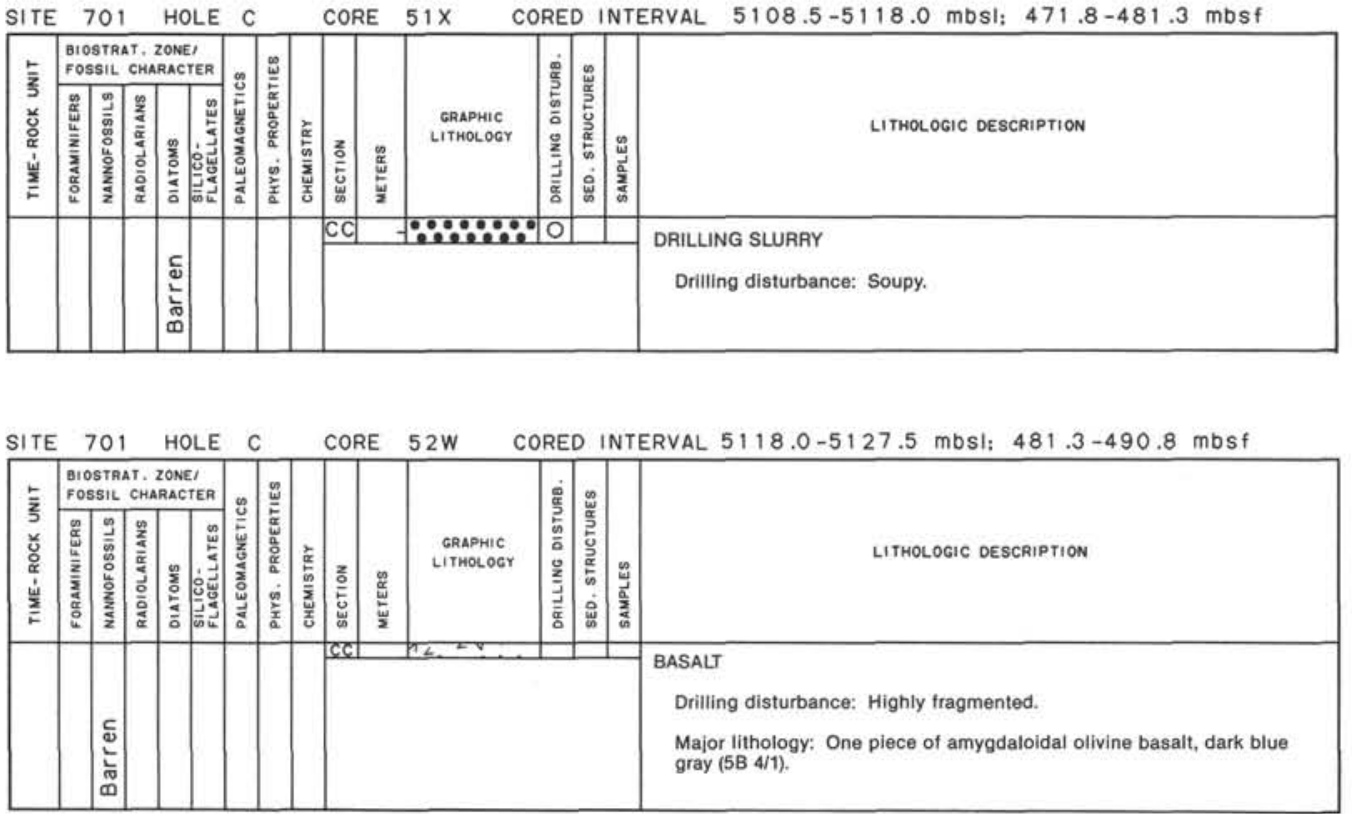

$150-$ 